UNIVERSIDADE DE SÃO PAULO

ESCOLA DE ENFERMAGEM

JANIE MARIA DE ALMEIDA

PROJETO TRANSMISSÃO VERTICAL ZERO: EXPECTATIVAS E AÇÕES DE PAIS SOROPOSITIVOS PARA O HIV À ESPERA DO DIAGNÓSTICO DO FILHO 
JANIE MARIA DE ALMEIDA

\section{PROJETO TRANSMISSÃO VERTICAL ZERO: EXPECTATIVAS E AÇÕES DE PAIS SOROPOSITIVOS PARA O HIV À ESPERA DO DIAGNÓSTICO DO FILHO}

Tese apresentada à Escola de Enfermagem da Universidade de São Paulo, para obtenção do título de Doutor em Enfermagem.

Orientadora: Prof. ${ }^{\mathrm{a}}$ Dr. ${ }^{\mathrm{a}}$ Neide de Souza Praça

SÃO PAULO

2008 
Catalogação na Publicação (CIP) Biblioteca "Wanda de Aguiar Horta"

\section{Escola de Enfermagem da Universidade de São Paulo}

Almeida, Janie Maria de.

Projeto Transmissão Vertical Zero: expectativas e ações de pais soropositivos para o HIV à espera do diagnóstico do filho. I Janie Maria de Almeida. - São Paulo, 2008.

$183 \mathrm{p}$.

Tese (Doutorado) Escola de Enfermagem da Universidade de São Paulo.

Orientadora: $\operatorname{Prof}^{\mathrm{a}} \mathrm{Dr}^{\mathrm{a}}$ Neide de Souza Praça.

1. HIV(diagnóstico) 2. Relações familiares 3. Enfermagem neonatal 4. Recém-nascido 5. Sorodiagnóstico da AIDS 6. Crença religiosa. I. Título. 


\section{DEDICATÓRIA}

Dedico este trabalho a mim mesma, pela incansável busca de conhecimento e aprendizado, e pela perseverança demonstrada ao longo do período de sua elaboração.

Dedico também ao meu querido esposo, Luís Carlos, e aos meus filhos, Júlia, Pedro Luiz e Luiz Eduardo que tantas felicidades e alegrias me dão, motivo deste trabalho. 


\section{AGRADECIMENTOS}

A Deus pela presença em toda minha vida, pela iluminação e força necessária para o enfrentamento das adversidades nesta trajetória.

Aos meus pais Jairo e Maria Aparecida pelo incentivo e empenho para que eu pudesse estudar.

À Professora Doutora Neide de Souza Praça, a quem admiro e respeito, pela dedicação em me orientar neste estudo, pela confiança e apoio.

Às Professoras Doutora Renata Ferreira Takahashi e Doutora Amélia Fumiko Kimura, pela participação no Exame de Qualificação com importantes observações.

Ao Departamento de Enfermagem da Pontifícia Universidade Católica de São Paulo, pelo apoio.

Aos alunos das $3 .^{\mathrm{a}}$ e $4 .^{\mathrm{a}}$ séries do curso de graduação em Enfermagem da PUC-SP pela compreensão e apoio.

Ao Conselho Nacional de Desenvolvimento Científico e Tecnológico CNPq, pelo apoio financeiro para a realização deste estudo.

A Secretaria Municipal de Saúde de Sorocaba/SP, por intermédio da coordenação do Programa Municipal de Doenças Sexualmente Transmissíveis e Aids, na pessoa da Dr. ${ }^{a}$ Maria José de Souza, pela autorização para a realização da pesquisa e fornecimento de informações das gestantes. Agradeço também à coordenação da Clínica Municipal de DST/Aids a acolhida e apoio. 
Às colegas do Grupo de Pesquisa em Enfermagem sobre a Transmissibilidade do HIV em Mulheres - GPETHIM, pela discussão do projeto e incentivo

À revisora da língua portuguesa, Prof. Joana D'Arc da S. Costa

À equipe da Biblioteca Wanda de Aguiar Horta, pelo auxílio e suporte durante o desenvolvimento deste trabalho.

Às mães e pais participantes desta pesquisa, pela colaboração, atenção e confiança e aos bebês que proporcionaram esta pesquisa, desejo-lhes muitas felicidades. 


\section{O TEMPO PASSA? NÃO PASSA}

O tempo passa? Não passa no abismo do coração.

Lá dentro, perdura a graça do amor, florindo em canção.

O tempo nos aproxima cada vez mais, nos reduz a um só verso e uma rima de mãos e olhos, na luz.

Não há tempo consumido nem tempo a economizar.

O tempo é todo vestido de amor e tempo de amar.

O meu tempo e o teu, amada, transcendem qualquer medida.

Além do amor, não há nada, amar é o sumo da vida.

São mitos de calendário tanto o ontem como o agora, e o teu aniversário é um nascer a toda hora.

E nosso amor, que brotou do tempo, não tem idade, pois só quem ama escutou o apelo da eternidade.

Carlos Drummond de Andrade 
Almeida JM. Projeto Transmissão Vertical Zero: expectativas e ações de pais soropositivos para o HIV à espera do diagnóstico do filho [Tese]. São Paulo: Escola de Enfermagem, Universidade de São Paulo; 2008.

\section{RESUMO}

O trabalho realizado pelo Projeto Transmissão Vertical Zero de Sorocaba, SP, e o elevado número de crianças expostas ao vírus da aids, no país, motivaram a realização deste estudo quanti-qualitativo que teve como objetivo geral compreender a vivência da mãe-pai enquanto aguardam o diagnóstico definitivo do lactente exposto à transmissão vertical do HIV. Esta pesquisa teve como referencial teórico a Antropologia Médica e a Narrativa como referencial metodológico. Os dados foram coletados em 2006. O momento quantitativo do estudo constou de caracterização das gestantes matriculadas no citado Projeto, no período de 1998 a 2004. O momento qualitativo contou com a participação de 11 mães e sete pais de lactentes expostos ao HIV. Os dados nessa fase foram coletados por meio de técnica projetiva (colagem) com gravação dos relatos sobre o sentido atribuído à construção. Com o tratamento dos dados qualitativos, emergiram seis temas: Sentimentos de esperança e confiança; ansiedade e expectativa; Espiritualidade e Religiosidade; Apoio; Preocupação com a saúde do filho; Preconceito e Fazendo analogia, que possibilitaram identificar as expectativas e as ações adotadas pelos pais enquanto aguardavam a confirmação do diagnóstico da criança. Os resultados mostraram que a vivência do núcleo familiar é marcada por intensa mobilização de sentimentos, preocupação com a saúde da criança e crença no tratamento. $\mathrm{O}$ preconceito e o estigma à aids revelaram-se como principais fontes estressoras, acarretando sofrimento e sentimento de culpa, que exigem empenho dos pais para se adaptarem ao Enfrentamento a cada nova situação cotidiana. Portanto, o Enfrentamento emergiu como tema central e mostrou que o cotidiano do binômio mãe-pai é vivido com ambigüidade de sentimentos. A tolerância às adversidades e aos transtornos é motivada pela afetividade e dedicação ao filho. A maneira de encarar e resistir ao infortúnio constituiu-se no Enfrentamento que gera atitudes paliativas ou de afastamento do convívio social, representadas pela busca de apoio espiritual e religioso, e também suporte social. Para os binômios atendidos no Projeto Transmissão Vertical Zero, o principal sustentáculo do Enfrentamento diante da indefinição do diagnóstico do filho é representado pela fé religiosa e pela crença em um Ser superior. As implicações destes achados são importantes para a enfermagem, que pode implementar cuidados culturalmente embasados, com a possibilidade de intervenções mais adequadas à clientela.

PALAVRAS-CHAVE: Transmissão Vertical, HIV, Enfermagem 
Almeida JM. Zero Vertical Transmission Project: HIV seropositive parents'

expectations and actions while waiting for their child's diagnosis. (Thesis) São Paulo

(SP), Brasil: Escola de Enfermagem, Universidade de São Paulo; 2008.

\begin{abstract}
The work carried out by the Zero Vertical Transmission Project in Sorocaba, SP, and the high number of children exposed to the aids virus in the country motivated this quantitative/qualitative study whose general objective is to understand the experience the parents live while waiting for the definite diagnosis of the infant exposed to the HIV vertical transmission. This research had the Medical Anthropology as theoretical reference and the Narrative as methodological reference. The data were collected in 2006. The study quantitative moment was when we characterized the pregnant women enrolled in the above mentioned project, from 1998 to 2004 . The qualitative moment counted on the participation of 11 mothers and 7 fathers of infants exposed to the HIV. The data in this phase were collected through the projective technique (collage) with recording of the reports about the meaning attributed to the construction. When treating the qualitative data, six topics came up : Hope and confidence feelings; Anxiety and expectation; Spirituality and religiosity; Support; Concerns about the child's health; Prejudice and Making an analogy, which enabled us to identify the expectations and actions adopted by the parents while waiting for the child's diagnosis confirmation. The results showed that the family nucleus experience is characterized by an intense mobilization of feelings, concern about the child's health and belief in the treatment. The prejudice and stigma to aids turned out to be the main stressful sources, causing suffering and a sense of guilt that the parents have to struggle against to adjust to the Coping in each daily new situation. Therefore, the Coping came up as the central theme and showed that the daily life of the binomial mother-father is lived with ambiguity of feelings. Accepting the adversity and the disorders is motivated by the affection and dedication to the child. The way to face and withstand the misfortune made up the Coping that generates palliative attitudes or social isolation, represented by the search for spiritual and religious support, besides the social support. For the binomial attended in the Zero Vertical Transmission Project, the main strength for the Coping while the child's diagnosis is not defined is represented by the religious faith and by the belief in a Superior Being. These findings' implications are important for the nursing which may implement a care based on the culture, with the possibility of interventions more suitable to the customers.
\end{abstract}

KEYWORDS: Vertical Transmission, HIV, Nursing. 
Almeida JM. Proyecto Transmisión Vertical Cero: expectativas y acciones de padres suero positivos para el VIH a la espera del diagnóstico del hijo [Tesis]. São Paulo (SP), Brasil: Escola de Enfermagem, Universidade de São Paulo; 2008.

\section{RESUMEN}

El trabajo realizado por el Proyecto Transmisión Vertical Cero de Sorocaba, SP, y el elevado número de niños expuestos al virus del sida, en el país, motivaron la realización de este estudio cuantitativo-cualitativo que tuvo como objetivo general comprender la vivencia de los padres en cuanto aguardan el diagnóstico definitivo del lactante expuesto a la transmisión vertical del VIH. Esta investigación tuvo como marco teórico el referencial de la Antropología Médica y la Narrativa como referencial metodológico. Los datos fueron colectados en el año de 2006. La fase cuantitativa del estudio constó de caracterización de las gestantes matriculadas en el citado Proyecto, en el período de 1998 a 2004. La fase cualitativa contó con la participación de 11 madres y siete padres de lactantes expuestos al VIH. Los datos en esta fase fueron colectados a través de técnica proyectiva (pegar o adherir figuras) con grabación de los relatos sobre el sentido atribuido a la construcción. Con el tratamiento de los datos cualitativos, emergieron seis temas: Sentimientos de Esperanza y confianza; Ansiedad y expectativa; Espiritualidad y religión; Apoyo; Preocupación con la salud del hijo; Preconcepto y Haciendo analogía, que posibilitaran identificar las expectativas y las acciones adoptadas por los padres en cuanto aguardaban la confirmación del diagnóstico del niño. Los resultados mostraran que la vivencia del núcleo familiar es marcada por intensa movilización de sentimientos, preocupación con la salud del niño y creencia en el tratamiento. $\mathrm{O}$ preconcepto y el estigma al SIDA se revelaran como principales fuentes estresantes, causando sufrimiento y sentimiento de culpa, que exigen empeño de los padres para adaptarse al Enfrentamiento a cada nueva situación cotidiana. Por tanto, el Enfrentamiento emergió como tema central y mostró que el cotidiano del binomio padre-madre es vivido con ambigüedad de sentimientos. La tolerancia a las adversidades y a los trastornos es motivada por la afectividad y dedicación al hijo. La manera de enfrentar y resistir al infortunio se constituyo en el Enfrentamiento que genera actitudes paliativas o de alejamiento del convivió social, representadas por la busca de apoyo espiritual y religioso, y también soporte social. Para los binomios

atendidos en el Proyecto Transmisión Vertical Cero, el principal sustentáculo del Enfrentamiento delante de la indefinición del diagnóstico del hijo es representado por la fe religiosa y por la creencia en un Ser superior. Las implicaciones de estas descubiertas son importantes para la enfermería, que puede implementar cuidados culturalmente basados, con la posibilidad de intervenciones más adecuadas a la clientela.

PALABRAS-CLAVE: Transmisión Vertical, VIH, Enfermería 


\section{LISTA DE FIGURAS}

Figura 1 - Distribuição das idades das Gestantes, matriculadas no Programa Transmissão Vertical Zero, Sorocaba, SP- 1998/2004.

Figura 2-Distribuição das gestantes, por faixa de escolaridade, matriculadas no Programa Transmissão Vertical Zero, Sorocaba, SP $1998 / 2004$

Figura 3 - Distribuição das gestantes, por ocupação, matriculadas no Programa Transmissão Vertical Zero, Sorocaba, SP - 1998/2004. ......66

Figura 4 - Distribuição das gestantes, por faixa de renda, matriculadas no Programa Transmissão Vertical Zero, Sorocaba, SP - 1998/2004. ......67

Figura 5 - Distribuição das gestantes, matriculadas no Programa Transmissão Vertical Zero, segundo seu estado civil, Sorocaba, SP - 1998/2004 ...67

Figura 6 - Motivos para realização do teste anti-HIV relatados pelas gestantes matriculadas no Programa Transmissão Vertical Zero, Sorocaba, SP $-1998 / 2004$.

Figura 7 - Diagrama dos Temas e Subtemas. 106

Figura 8 - Diagrama ilustrativo dos Temas Analisados - fase 1......................107

Figura 9- Diagrama ilustrativo dos Temas Analisados - fase 2.......................107

Figura 10 - Diagrama ilustrativo da Vivência de mães e pais 


\section{LISTA DE TABELAS}

Tabela 1 - Número de filhos vivos por gestante da amostra, Sorocaba, SP $1998 / 2004$

Tabela 2 - Número de filhos mortos por gestante da amostra, Sorocaba, SP $1998 / 2004$

Tabela 3 - Situação informada da condição sorológica para o HIV do parceiro, por gestantes, matriculadas no Programa Transmissão Vertical Zero, Sorocaba, SP - 1998/2004

Tabela 4 - Freqüência de uso de preservativo segundo relato das gestantes matriculadas no Programa Transmissão Vertical Zero, Sorocaba, SP - 1998/2004

Tabela 5 - Fatores de exposição ao HIV relatados pelas gestantes matriculadas no Programa Transmissão Vertical Zero, Sorocaba, $\mathrm{SP}-1998 / 2004$

Tabela 6 - Orientação sexual das gestantes, segundo relato das gestantes matriculadas no Programa Transmissão Vertical Zero, Sorocaba, $\mathrm{SP}-1998 / 2004$

Tabela 7 - Número de parceiros relatado pelas gestantes matriculadas no Programa Transmissão Vertical Zero, Sorocaba, SP - 1998/2004 


\section{LISTA DE SIGLAS}

\begin{tabular}{|c|c|}
\hline ACTG & Aids Clinical Trials Group \\
\hline ADT & Assistência Domiciliar Terapêutica \\
\hline Aids & Acquired Immunodeficiency Syndrome \\
\hline $\mathrm{AZT}$ & Zidovudina \\
\hline bDNA & branched-chain DNA \\
\hline $\mathrm{CD}_{4}$ & Cluster of Differentiation 4 \\
\hline COAS & Centro de Orientação e Apoio Sorológico de Sorocaba \\
\hline CTA & Centro de Testagem Anônima \\
\hline DNA & Deoxyribonucleic Acid \\
\hline DRS & Departamento Regional de Saúde \\
\hline DST & Doenças Sexualmente Transmissíveis \\
\hline ELISA & Enzyme-Linked Immunosorbent Assay \\
\hline GEPASO & Grupo de Prevenção e Apoio à AIDS de Sorocaba \\
\hline HIV & Human Immunodeficiency Virus \\
\hline HTLV-I & Human T-lymphotropic Virus \\
\hline INSS & Instituto Nacional de Seguridade Social \\
\hline NASBA & Nucleic Acid Sequenced Based Amplification \\
\hline OMS & Organização Mundial da Saúde \\
\hline ONG & Organização Não-Governamental \\
\hline PCR & Polymerase Chain Reaction \\
\hline PN-DST/Aids & Programa Nacional DST/Aids \\
\hline RNA & Ribonucleic Acid \\
\hline SAE & Serviço de Assistência Especializado \\
\hline SES & Secretaria Municipal da Saúde \\
\hline $\operatorname{SPSS}^{\circledR}$ & Statistical Package for the Social Sciences \\
\hline SUS & Sistema Único de Saúde \\
\hline TARV & Terapia Anti-Retroviral \\
\hline TMI & Transmissão Materno-Infantil \\
\hline
\end{tabular}


$\begin{array}{ll}\text { UBS } & \text { Unidade Básica de Saúde } \\ \text { UNAIDS } & \text { Joint United Nations Programme on HIV and Aids } \\ \text { WHOQOL-100 } & \text { World Health Organization Quality of Life Instrument - } 100 \\ \text { WHOQOL-SRPB } & \text { WHOQOL - Spirituality, Religiousness and Personal Beliefs }\end{array}$ 


\section{SUMÁRIO}

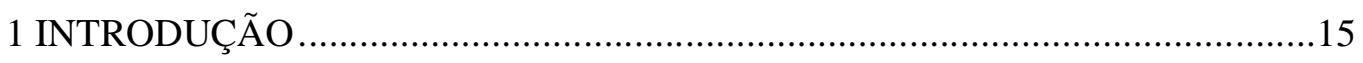

1.1 A EPIDEMIA DE AIDS E AS MULHERES...............................................17

1.2 A MULHER SOROPOSITIVA E A GESTAÇÃO ..........................................

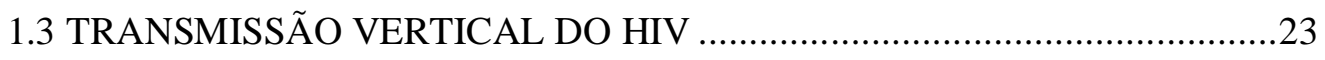

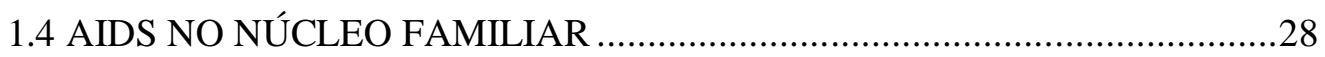

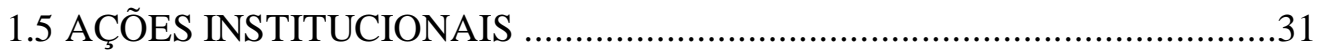

2 PROJETO TRANSMISSÃO VERTICAL ZERO....................................................

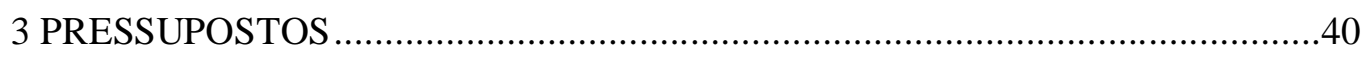

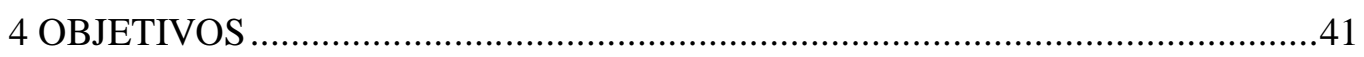

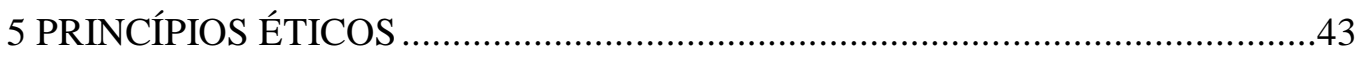

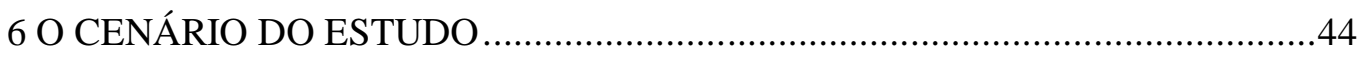

7 DESCREVENDO A COLETA E O TRATAMENTO DOS DADOS .......................45

7.1 PRIMEIRO MOMENTO - MÉTODO QUANTITATIVO................................45

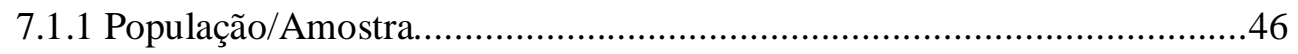

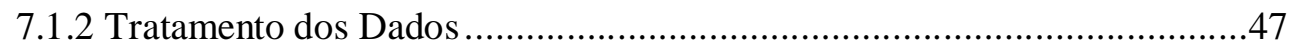

7.2 SEGUNDO MOMENTO - MÉTODO QUALITATIVO ………………..........47

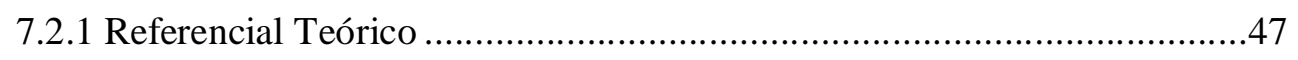

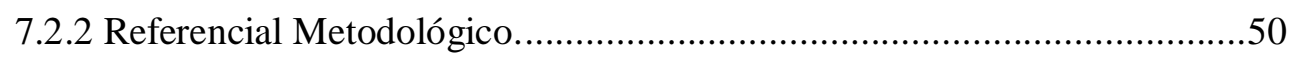

7.2.3 Trajetória da Coleta de Dados.................................................................

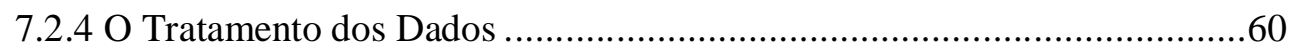

8 CARACTERIZANDO AS GESTANTES MATRICULADAS NO PROJETO

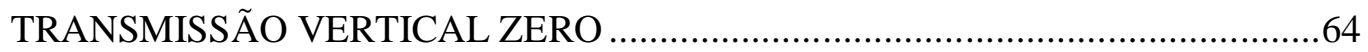

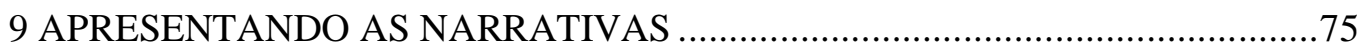

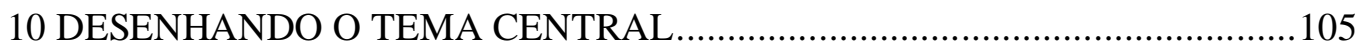

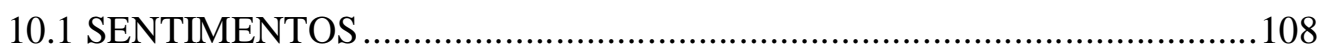

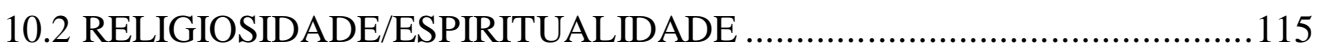

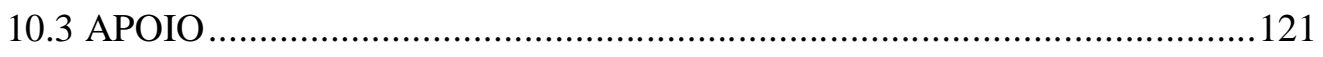

10.4 PREOCUPAÇÃO COM A SAÚDE DO FILHO .......................................127

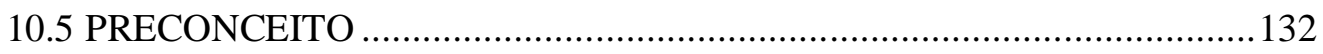

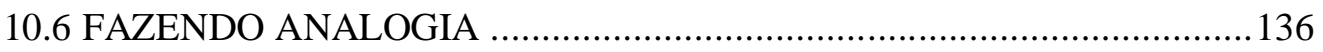




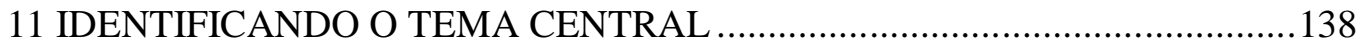

12 CONSIDERANDO OS ASPECTOS CULTURAIS …................................. 142

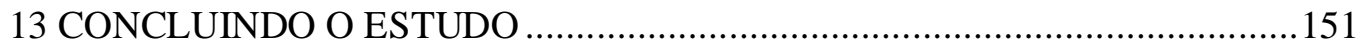

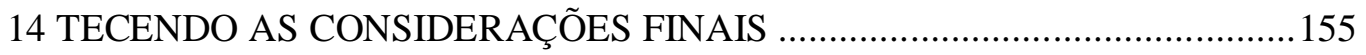

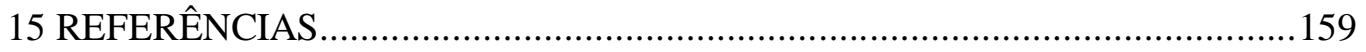

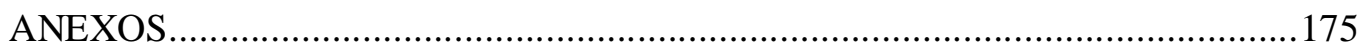

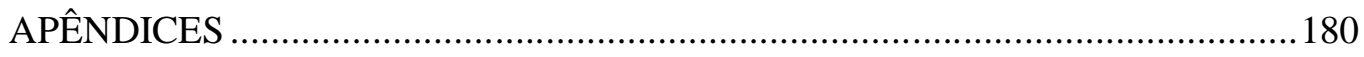




\section{INTRODUÇÃO}

O tema Síndrome da Imunodeficiência Adquirida, conhecida no Brasil pela sigla Aids ${ }^{1}$ chamou minha atenção desde os primeiros comentários da doença no ambiente de trabalho, em 1985, e, especialmente, quando foi anunciado, para a mídia, o inesperado falecimento de um famoso ator de Hollywood, infectado, que se tornou um símbolo do problema e colocou em evidência a questão da sexualidade.

Presume-se que não só por ser uma novidade, mas também por expor temas como sexo, morte, promiscuidade e uso de drogas, principalmente, por caracterizar-se em epidemia com aspecto sui generis, à medida que a transmissão do HIV expunha a intimidade da pessoa infectada, trouxe à tona, de forma acentuada, questões de cunho cultural e moral que passaram a ser discutidas pela sociedade (Lagonegro, 2005).

Minha atuação profissional vem se construindo paralelamente à epidemia da aids, pois terminei o curso de graduação em Enfermagem em 1984, durante o qual não me recordo do tema ter sido abordado. No primeiro emprego, na Santa Casa de Angatuba, cidade do interior do Estado de São Paulo, obtive informações advindas da Secretaria de Estado da Saúde, sobre o conhecimento existente até então. No entanto, o maior volume de notícias sobre a epidemia foi adquirido por meio da imprensa leiga, situação também constatada por Galvão (2002) em uma análise sobre a doença e a mídia.

\footnotetext{
${ }^{1}$ Aids (do inglês Acquired Immunodeficiency Syndrome), causada pelo vírus HIV (do inglês Human Immunodeficiency Virus).
} 
Ao iniciar a atividade na docência, no curso de graduação em Enfermagem da Pontifícia Universidade Católica de São Paulo, em 1987, ministrando as disciplinas Enfermagem em Obstetrícia e Enfermagem em Doenças Transmissíveis, fui instada a me aprofundar na temática relacionada à Aids.

Outro momento importante, relevante e profícuo, no meu contato com a temática, ocorreu no período em que desenvolvi atividades no serviço de Vigilância Epidemiológica da Prefeitura Municipal de Sorocaba, São Paulo, de 1992 a 1997, que acabava de ser municipalizado, iniciando uma nova fase nas ações de vigilância das doenças, juntamente com o diagnóstico de saúde do Município.

Naquela época, atuava como enfermeira responsável por atribuições diversas, e, especialmente, as que envolviam a Aids, e que se caracterizavam por campanhas de prevenção, em ações de vigilância, com treinamentos para profissionais de saúde e de educação da rede municipal.

Dada à realidade do citado Município naquele período, em relação à epidemia da Aids, que apresentava índices crescentes de casos e ocupava a 14. ${ }^{\mathrm{a}}$ posição no levantamento do Ministério da Saúde, houve reunião da área técnica da Seção de Vigilância Epidemiológica, responsável pelas questões que envolviam a problemática, suscitando esforços na busca e proposição de medidas para responder à progressiva demanda de doentes. Uma das ações correspondeu à incorporação da proposta do Ministério da Saúde para a criação de um Centro de Testagem Anônima - CTA (Sorocaba, 2001).

Esse centro de testagem foi o embrião do Programa Municipal de DST/Aids, denominado COAS (Centro de Orientação e Apoio Sorológico de Sorocaba), inaugurado em 1993. Posteriormente, foi criado o Serviço de Assistência Especializado (SAE), denominado Clínica DST/Aids, que conta também com a Assistência Domiciliar Terapêutica (ADT) aos pacientes portadores do HIV/Aids.

Apesar de, 1997, não ser mais vinculada à Prefeitura Municipal de Sorocaba, por opção pessoal e profissional, mantive uma aproximação com a equipe que atuava no referido programa.

Essa trajetória ensejou questionamentos que foram determinantes para eu estudar a relação da doença numa interação professor-aluno, o que me possibilitou compreender melhor as dimensões dessa relação, assim, desenvolvi a dissertação de mestrado intitulada "Representações sociais sobre Aids e sua influência no processo 
ensino-aprendizagem de um grupo de alunas de enfermagem da PUC-SP" (Almeida, 1999).

Dessa maneira, ao longo dos anos, tenho acompanhado a evolução da epidemia e sua mudança de perfil. As grandes transformações no quadro epidemiológico da aids, no Brasil, tanto na principal via de transmissão quanto no perfil dos portadores do HIV, têm mostrado que, apesar da enormidade de informações produzidas pelos avanços científicos, a aids continua sendo uma doença cercada por mitos, por preconceitos morais e sociais, que podem afetar o aspecto psicológico, as relações familiares, afetivas, sociais e profissionais do portador do HIV/Aids.

Após mais de duas décadas e grandes progressos nas pesquisas, sua cura ainda permanece desafiadora para a sociedade, e também, para as equipes de saúde, principalmente, pelas características que configuram a aids, englobando tanto questões clínicas como sociais e morais; pois, desde o momento do diagnóstico, o portador do HIV sofre grande impacto, que gera sobrecarga emocional que leva às mudanças de comportamento e do modo de viver e de perceber a vida (Carvalho, Braga, Galvão, 2004).

Após esta breve apresentação de minha aproximação com a epidemia de Aids, julgo, portanto, pertinente melhor detalhar esta doença, com foco na mulher, minha área de estudo, e no contexto, campo desta pesquisa.

\subsection{A EPIDEMIA DE AIDS E AS MULHERES}

A epidemia de Aids, no Brasil, experimentou modificações profundas desde o seu início na década de 1980, no entanto, apresenta estabilidade da prevalência do HIV abaixo de $1 \%$ na população geral (Fry et al., 2007). Em análise de Fonseca, Bastos (2007) sugerem que é mais apropriado não se referir como uma única epidemia, mas como um mosaico de epidemias regionais, refletindo a extensão sociogeográfica, a diversidade do país, e sua heterogeneidade regional. Inicialmente, circunscrita a centros urbanos e restrita a determinados segmentos populacionais, expandiu-se para o interior do país nos anos de 1990, caracterizando o processo de 
interiorização. Apesar desta evidência, a epidemia da Aids no Brasil é predominantemente urbana, devido à grande concentração de população em cidades, uma vez que estes centros urbanos, com mais de 200 mil habitantes, exibem taxas de crescimento de infectados. Há recentes indicações de que a população rural ingressou no processo disseminação da epidemia, fato comprovado pelas taxas de incidência ascendentes, porém ainda relativamente baixas, entre trabalhadores rurais (Fonseca, Bastos, 2007).

O fenômeno da pauperização, identificado como uma das principais alterações do perfil dos infectados, caracteriza-se pela mudança nos estratos sociais de maior para menor escolaridade, com progressiva disseminação do HIV, evidenciada a partir dos anos de 1990, fato difundido pelo PN-DST/Aids (Fonseca et al., 2000; Rodrigues Júnior, Castilho, 2004; Chequer, 2005; Farias, Cardoso, 2005).

Por outro lado, Fry et al. (2007) examinaram o banco de dados sobre a ocorrência de HIV/Aids no Brasil até 2005, com enfoque no contexto sociopolítico envolvido na definição de políticas públicas de recorte racial, e argumentam contrariamente sobre a afirmação de que a epidemia vem crescendo de forma particularmente acelerada entre os pobres, ao realizar a análise da variável escolaridade, única que permite informar sobre a condição socioeconômica. Esse resultado, juntamente com a análise da variável cor/raça, revela dados proeminentes, que sugerem ter havido uma reversão da tendência de pauperização da epidemia da Aids e que o suposto aumento na "população negra" resulta de um aumento somente entre os pardos, mas não entre os negros.

Tal artigo gerou alguns debates, que consideraram prematuro descartar a pauperização da epidemia de HIV/Aids no Brasil como um aspecto importante de sua evolução (Camargo Júnior, 2007).

Quanto às categorias de exposição, também sofreram alterações. A incidência de casos pela via de transmissão heterossexual (heterossexualização) foi a que mostrou o maior aumento, porém, a epidemia brasileira não se caracteriza como completamente "heterossexualizada", como observado na África. No país, a categoria de homossexual/bissexual masculino representa ainda um fator importante na transmissão de HIV pela via sexual.

As mudanças no perfil do infectado pelo HIV, ao longo de duas décadas e meia, mostram de forma decisiva a expansão da epidemia entre as 
mulheres, sobretudo entre aquelas em idade fértil, o que caracteriza o fenômeno denominado de feminilização da aids, transformando as mulheres progressivamente no segmento mais importante da população, para a dinâmica da epidemia no Brasil (Brasil, 1995; Parker, Galvão, 1996; Brito, Castilho, Szwarcwald, 2000; Brasil, 2003a; Instituto, 2003; Souza Júnior et al., 2004; Brasil, 2007a; Fonseca, Bastos, 2007).

Desde o aparecimento da doença no Brasil, em 1980, ainda que os casos tenham aumentado significativamente no período, observa-se mudança na proporção masculino/feminino da incidência da doença.

Se em 1986, ano em que as notificações ultrapassaram a 1.000 casos, a razão masculino/feminino era 15,1 para 1, ou seja, dos 1.178 casos, apenas 73 eram de mulheres (Brasil, 2007b).

Desde então, esta razão vem se reduzindo, em 2002, dos 38.816 casos de aids notificados 15.398 eram de mulheres, o que perfaz a razão masculino/feminino de 1,5 para 1, razão que se estabiliza neste patamar até 2006, período compreendido pelo último boletim (Brasil, 2007b), situação esta que ilustra o processo de feminilização da doença.

Os dados epidemiológicos mostram que, em 1985, apenas 3,7\% dos infectados eram mulheres, mas atualmente, essa proporção é de 40,6\% (Brasil, 2007b).

A taxa de incidência na população geral cresceu continuamente até 2002, auge da doença, com 38.816 casos novos notificados, quando chegou a 22,2 casos por grupo de 100.000 habitantes. Naquele período, a incidência por sexo era de 27,2 para os homens e 17,4 para as mulheres por 100 mil habitantes.

Desde 2002 observa-se que o número de casos de aids em mulheres vem se reduzindo com a conseqüente redução na taxa de incidência. Os últimos dados mostram que no ano de 2006 foram notificados 32.628 casos, com incidência, para os homens, de 21,1 e, para as mulheres, 14 casos para 100 mil habitantes.

Ao julgar pelos dados recentes, conclui-se que a razão Masculino/Feminino estabilizou-se em 1,5, ao passo que a incidência apresenta tendência de queda (Brasil, 2007b).

Outro ponto relevante é a faixa etária de 20 a 49 anos que apresenta o maior número de notificações da aids, com percentual considerável de pessoas entre 
20 e 29 anos de idade, principalmente do sexo feminino. Essas pessoas estão na faixa etária sexualmente ativa, ou seja, em plena fase reprodutiva, e muitas vezes o desejo de maternidade ainda não se concretizou ou está se concretizando. Esta situação se reflete no aumento da transmissão do vírus HIV para o feto/recém-nascido.

A presença da mulher na epidemia da aids é reflexo do comportamento sociossexual da população, que se associa aos aspectos de suscetibilidade biológica, maior eficácia na transmissão do homem para a mulher, que sofre mais doenças sexualmente transmissíveis assintomáticas e úlceras genitais, e de gênero, pois a maioria das mulheres depende econômica, social e emocionalmente dos homens (Pan-American Health Organization, 2000; Brasil, 2004a; Braga, Cardoso, Segurado, 2007).

Por outro lado, um dado significativo é que grande número das mulheres não se sente sob risco (Santos et al., 2002; Brasil, 2003a; Souza Júnior et $a l .$, 2004). Concordo com as autoras quando referem que as ações de atenção à saúde devem reconhecer o aspecto cultural que permeia a relação do casal, bem como se identifica a mulher como ponto vulnerável na cadeia de transmissão do HIV, interferindo junto ao casal para modificar esta condição (Praça, Gualda, 2001).

Essa situação chama atenção para a necessidade da assistência prestada à mãe soropositiva que, motivada a cuidar do filho, poderá desenvolver forças para o autocuidado. Os achados de Brito, Cruz (2003) organizadoras da publicação: "Fios da Vida - Tecendo o feminino em tempos de aids", trabalho de pesquisa desenvolvido pela Rede Paulista de Mulheres com HIV/Aids, cap. II, mostram que:

muitas mulheres não desistiram de lutar para viver porque tinham os filhos, a responsabilidade pelas crianças se por um lado é peso e exigência, por outro lado é a possibilidade de ainda poder cuidar de alguém, raiz que traz a mulher para o chão concreto, conferindo sentido para o seu viver.

A situação da mulher na epidemia da aids tem gerado esforço conjunto entre as Organizações Não-Governamentais (ONGs) ligadas às mulheres soropositivas, e o Ministério da Saúde, cujo objetivo é promover/fomentar a conscientização e as ações no sentido de "unir as mulheres com HIV para quebrar o isolamento causado pelo preconceito e estigma decorrentes da doença”, e de 
melhorar a auto-estima dessas mulheres e capacitá-las politicamente para ocupar espaço na luta contra a aids (Grupo Incentivo Vida, 2005).

Nesse sentido, desde 1996, a Rede Paulista de Mulheres com HIV/Aids desenvolve estratégia visando à contribuição para o empoderamento das mulheres vivendo com HIV/Aids e para a discussão sobre temas que envolvem a questão.

\subsection{A MULHER SOROPOSITIVA E A GESTAÇÃO}

O envolvimento feminino na epidemia da aids está diretamente vinculado ao número de crianças infectadas pela transmissão vertical do HIV.

A associação do HIV à gestação, torna-a uma condição de alto risco, que necessita de abordagem adequada e completa durante o pré-natal, o parto e o puerpério, com o objetivo de reduzir os níveis de risco de infecção para próximos ao de gestantes não infectadas, merecendo, além disso, atenção que envolva também os aspectos psicológicos, sociais e familiares da mulher HIV positivo de forma a proporcionar-lhe tratamento tecnicamente correto e humanizado (Brasil, 2001 e 2007c).

Dessa forma, o Ministério da Saúde recomenda a testagem anti-HIV tão logo a mulher inicie seu pré-natal, caso perca essa oportunidade, o teste deverá ser realizado em qualquer outro momento da gestação, no parto ou mesmo no puerpério, neste visa a prevenir a transmissão pela amamentação, substituindo o aleitamento materno pelo leite artificial - fórmula láctea (Galvão, 2002; Sampaio Neto et al. 2002; Brasil, 2004b; Gianvecchio, Goldberg, 2005).

No Brasil, o acesso de todas as gestantes HIV positivo ao tratamento com o AZT e outros anti-retrovirais é uma das prioridades da política de tratamento da Coordenação Nacional de DST/Aids, fato que permite o aumento da qualidade de vida dessas mulheres e a diminuição da transmissão materno-infantil do HIV, embora as estimativas do Programa Nacional de DST/Aids para o ano de 2001 apontavam que apenas $35 \%$ das gestantes infectadas teriam acesso à terapia antiretroviral com uso de zidovudina (AZT) (Souza Júnior et al., 2004). 
No entanto, apesar dessa baixa cobertura, nos últimos anos, tem-se observado redução das taxas de transmissão vertical. Se no período de 1997 a 2001, dados da Coordenação Nacional de DST/Aids apontavam taxa de prevalência da infecção em parturientes de $0,6 \%$, em 2004, esta foi reduzida para $0,413 \%$, o que equivale a uma estimativa/ano de aproximadamente 12.635 gestantes infectadas. Especificamente em se tratando da Região Sudeste, conforme explicitado a seguir, o valor é significativamente menor ao descrito por Souza, Júnior et al. (2004), de 16\% para o Estado de São Paulo. Vale esclarecer que o período desse estudo foi anterior à introdução da terapia anti-retroviral.

Em estudo do Ministério da Saúde, com enfoque específico nas Regiões do Brasil, verificaram-se distintos índices relacionados à transmissão vertical, indicando para a Região Norte a menor taxa de transmissão vertical 0,15\%, e para a Região Sudeste, a maior taxa $(0,53 \%)$. Esses dados indicam um reflexo da realidade assistencial das gestantes atendidas por Regiões, pois, as estimativas da cobertura de teste anti-HIV, na gestação, apontam diferenças significativas entre elas, e essas desigualdades são ressaltadas no momento de sua comparação (Brasil, 2007a; Succi, 2007).

É bem provável que as taxas apuradas, principalmente nas regiões menos desenvolvidas, indicam valores subestimados, uma vez que falhas na detecção da infecção pelo HIV entre gestantes brasileiras alcançam todas as etapas do processo, desde vinculação ao pré-natal, até a ausência do pedido do teste sorológico anti-HIV e falta de conhecimento do resultado antes do parto (Cavalcante et al., 2004; Souza Júnior et al., 2004; Fernandez, Araújo, Medina-Acosta, 2005; Lemos, Gurgel, Fabbro, 2005; Brasil, 2007a; Succi, 2007). Essa condição assistencial pode explicar o reduzido valor da taxa de prevalência de transmissão vertical observado na Região Norte, citada anteriormente.

Nesta direção, é importante ressaltar que para as Regiões Norte e Nordeste, as gestantes que cumpriram todas as etapas do atendimento pré-natal (pelo menos uma consulta, solicitação de teste anti-HIV, concordância da gestante em realizá-lo, e conhecimento do resultado antes do parto) não ultrapassam 35\%, enquanto nas Regiões Centro-Oeste, Sul e Sudeste figuram com proporções superiores a $75 \%$ (Brasil, 2007a).

Essa situação leva à deficiência da detecção precoce da infecção pelo 
HIV durante o pré-natal, principalmente nas regiões mais pobres do país, e representa uma oportunidade perdida de intervenção na atenção à gestante infectada, limitando as possibilidades de redução da transmissão materno-infantil (Cavalcante et al., 2004; Brasil, 2005a; Fernandez, Araújo, Medina-Acosta, 2005; Lemos, Gurgel, Fabbro, 2005).

\subsection{TRANSMISSÃO VERTICAL DO HIV}

Em vista do exposto, o contexto apresentado mostra que as crianças são submetidas a risco crescente à infecção pelo HIV, com nítidos percentuais na incidência das que já nascem infectadas por transmissão materno-infantil.

A crescente taxa de infecção pelo HIV na população feminina em idade fértil, até meados da década de 1990, possibilitava o aumento correspondente de infecções congênitas, com os casos de HIV entre crianças infectadas pela via vertical também refletindo as baixas coberturas das ações profiláticas, devido à precariedade de acesso para acompanhamento pré-natal e sua baixa qualidade, caracterizado pelo não oferecimento do teste anti-HIV às mulheres grávidas, situação que, no Brasil, ocorre em 22,5\% dos casos e na Região Nordeste este índice é de 46,5\% (Szwarcwald, Barbosa, Fonseca, 2001; Araújo, Vieira, Bucher, 2006; Fonseca, Bastos, 2007).

Vale acrescentar que a transmissão vertical pode ocorrer em qualquer fase do ciclo grávido-puerperal, embora o momento mais crítico seja o periparto, principalmente, durante o trabalho de parto e parto (65\%). Os 35\% restantes envolvem as últimas semanas da gestação enquanto que o aleitamento materno compreende taxas entre 7 a 22\% (Melo, 1999; Azevedo, 2001; Brasil, 2003a, 2004a; Duarte, Quintana, El Beitune, 2005; Gianvecchio, Goldberg, 2005; Brito et al., 2006). $\mathrm{Na}$ ausência de qualquer intervenção, a taxa de transmissão vertical do HIV situa-se em torno de $20 \%$. No entanto, quando são adotadas medidas específicas, é possível reduzir esta taxa para níveis entre zero e $2 \%$, principalmente com o uso de antiretrovirais combinados, de cesariana eletiva e diante de carga viral menor do que 1.000 cópias/ml ao final da gestação (Brasil, 2007c).

No Brasil, a transmissão materno-infantil continua sendo a principal 
via de infecção pelo HIV em crianças, apesar de todas as medidas de prevenção e uso do AZT para diminuir a taxa de transmissão vertical, positivamente comprovado pelo Protocolo 076 ACTG - Aids Clinical Trials Group ${ }^{2}$. Enquanto na década de 1980, a transmissão vertical era responsável por $47 \%$ dos casos pediátricos, cumulativamente, o período de 1983-2006 é responsável por 83,4\% do total de casos em menores de 13 anos, computando 10.526 casos (Brasil, 2007b).

Essa tendência de aumento foi parcialmente revertida pela instituição das medidas implementadas com o Protocolo ACTG 076 em todo o país, constata-se redução significativa no número de casos de aids pediátricos (Vasconcelos, Hamann, 2005; Brito et al., 2006; Fonseca, Bastos, 2007).

Tendo como meta a redução da transmissão vertical do HIV pela detecção e tratamento da gestante infectada, o Ministério da Saúde busca conhecer a prevalência do HIV em gestantes e crianças expostas. Para isso, tornou obrigatória a notificação das gestantes HIV positivo, prevista na Portaria n. ${ }^{\circ} 993$ GM/MS, de 4 de setembro de 2000 e passou a utilizar a "Ficha de Investigação de Gestantes HIV positivas e Crianças Expostas”, pautando-se o diagnóstico laboratorial de infecção pelo HIV em conformidade com as normas e procedimentos estabelecidos pelo Ministério da Saúde. Da mesma forma, é obrigatória a notificação das crianças nascidas de mães infectadas ou que tenham sido amamentadas por mulheres infectadas pelo HIV (Brasil, 2007c).

Outra medida adotada pelo PN-DST/Aids é a emissão do documento "Recomendações para Profilaxia da Transmissão Vertical do HIV e Terapia AntiRetroviral em Gestantes", revisado periodicamente, no qual estão contidas as condutas adequadas para a condução do pré-natal e parto de mulheres soropositivas para o HIV, visando ao fortalecimento dessa ação de controle.

No entanto, ao estudar a transmissão vertical do HIV, percebi a necessidade de fundamentar o objeto deste estudo e de compreender o diagnóstico da infecção em crianças, conforme preconizado pelo consenso "Fluxograma para Diagnóstico da Infecção pelo HIV em Crianças”, que visa/norteia a detecção/confirmação da infecção pelo HIV em crianças entre dois e 18 meses,

\footnotetext{
${ }^{2}$ O Protocolo 076 ACTG recomenda que seja administrado AZT à gestante (via oral) a partir da $14 .{ }^{\mathrm{a}}$ semana de gestação (componente pré-parto), endovenoso durante o trabalho de parto e parto (componente peri-parto) e administrado via oral ao recém-nascido por seis semanas (componente pósparto) (Brasil, 2007c).
} 
nascidas de mães infectadas pelo HIV (Brasil, 2004b).

Vale ressaltar que os testes para detecção da infecção pelo HIV podem ser divididos em quatro grupos: detecção de anticorpos, detecção de antígenos, cultura viral e amplificação do genoma do vírus. As técnicas rotineiramente utilizadas para o diagnóstico da infecção pelo vírus da aids - ELISA (Enzyme-Linked Immunosorbent Assay ${ }^{3}$ ), Western-blot e Imunofluorescência Indireta - são baseadas na detecção de anticorpos, que apresentam resultados satisfatórios e são menos dispendiosas, sendo de escolha para toda e qualquer triagem inicial. (Brasil, 1999a).

Os testes de detecção de antígeno viral são caracterizados pela pesquisa de Antígeno p24, que quantifica a concentração da proteína viral p24 presente no plasma ou no sobrenadante de cultura de tecido. Embora esta proteína esteja presente no plasma de pacientes em todos os estágios da infecção pelo HIV, sua maior prevalência ocorre antes da soroconversão e nas fases mais avançadas da doença. A indicação é no diagnóstico laboratorial precoce de infecções pelo HIV-1, na fase anterior à conversão sorológica e no diagnóstico da infecção pelo HIV-1 no recém-nascido de mãe soropositiva. A técnica mais empregada para a pesquisa de antígeno p24 é o teste de ELISA (Brasil, 1999a; Machado, Costa, 1999).

As técnicas de cultura viral baseiam-se em cultura de células mononucleares de sangue periférico para isolamento do HIV, que são observadas quanto à evidência de formação sincicial (células gigantes multinucleadas), presença de atividade da transcriptase reversa e produção de antígeno p24 em sobrenadantes, e cultura quantitativa de células e de plasma, que medem a carga viral intracelular (Brasil, 1999a; Machado, Costa, 1999).

Os testes de ampliação do genoma do HIV compreendem a análise quantitativa direta da carga viral por meio de técnicas baseadas na amplificação de ácidos nucleicos. Dentre as várias técnicas para realização destes testes, temos:

- detecção do DNA do HIV-1 integrado ao genoma leucocitário (PCR-DNA quantitativo), que usa a reação em cadeia de polimerase-polymerase chain reaction- $P C R$;

\footnotetext{
${ }^{3}$ Teste Imunoenzimático
} 
- detecção do RNA do HIV-1 no plasma (PCR-RNA qualitativo), que emprega PCR após transcrição reversa (RT-PCR).

Ambos indicados para o diagnóstico de infecção pelo HIV-1, em crianças nascidas de mães soropositivas, sendo altamente específico e sensível em lactentes de um a dois meses de idade, por sua vez, outro método é a detecção do RNA do HIV-1 no plasma (quantitativo) ou determinação da Carga Viral (Machado, Costa, 1999), cujas técnicas mais freqüentemente empregadas para sua determinação são: PCR quantitativo por competição, branched-chain DNA (bDNA), NASBA (Nucleic Acid Sequenced Based Amplification) Machado, Costa (1999).

Em julho de 2006, o Ministério da Saúde emitiu nota técnica ${ }^{4}$ que definiu os critérios de evidência laboratorial da infecção pelo HIV. Para as crianças menores de 18 meses de idade, expostas ao HIV por transmissão vertical, considerase infectada quando houver a presença de RNA viral plasmático detectáve1 acima de 10.000 cópias/ml ou detecção do DNA pró-viral em duas amostras obtidas em momentos diferentes

Por sua vez, essa nota apresenta como critérios para encerramento de caso para criança exposta ao HIV menores de 18 meses, resultado positivo em duas amostras em momentos diferentes, testadas pelos métodos de quantificação de RNA viral plasmático ou detecção do DNA pró-viral, quando de criança infectada.

No caso de criança não infectada, a Nota Técnica preconiza duas amostras que apresentam resultados abaixo do limite de detecção, por meio da quantificação do RNA viral plasmático ou detecção do DNA pró-viral. Com a segunda amostra realizada após o $4 .^{\circ}$ mês de vida, e sorologia anti-HIV negativa, após os 12 meses de idade.

Esse período exige atenção contínua dos pais e envolvimento com os cuidados do filho, pois o recém-nascido verticalmente exposto ao HIV necessita de acompanhamento em serviço especializado, para realizar a profilaxia com Zidovudina (solução oral de AZT), que deverá ser administrada, de preferência, imediatamente após o nascimento (nas duas primeiras horas) ou nas primeiras oito horas de vida, e deverá ser mantida durante as seis primeiras semanas - 42 dias (Brasil, 2007c).

A rotina de acompanhamento clínico e laboratorial da criança exposta

${ }^{4}$ Nota Técnica N. ${ }^{\circ}$ 116/06/UIV/PN-DST-AIDS/SVS/MS de 20 de julho de 2006. 
ao HIV deve ser mensal nos primeiros seis meses e, no mínimo, trimestral a partir do 2. ${ }^{\circ}$ semestre de vida. A avaliação sistemática do crescimento e do desenvolvimento é extremamente importante, visto que as crianças infectadas podem, já nos primeiros meses de vida, apresentar dificuldade de ganho de peso (Brasil, 2004c).

Importante destacar que as crianças nascidas de mães infectadas pelo HIV também podem ter maior risco de exposição a outros agentes infecciosos durante o período intra-uterino e perinatal. Destacam-se sífilis, vírus das hepatites B e C, vírus HTLV-I, vírus do herpes simples, citomegalovírus, Toxoplasma gondii e Mycobacterium tuberculosis (Brasil, 2004c).

Nesse sentido, a indicação de métodos diagnósticos específicos para tais agentes deve ser analisada em conjunto com os dados de história e epidemiológicos que envolvem o núcleo familiar, sobretudo aqueles referentes à mãe biológica. O conjunto de exames está pautado na necessidade de monitoramento dos efeitos adversos devido à exposição intra-uterina e pós-natal aos anti-retrovirais, bem como na importância da identificação precoce das repercussões sistêmicas da infecção pelo HIV (Brasil, 2004c).

Como forma de efetivação das ações que visam a reduzir a transmissão vertical, a mãe HIV positivo e a criança exposta devem ser acompanhadas no SAE, que atende aos pacientes portadores do HIV/Aids em nível ambulatorial. A principal característica desses serviços é a presença de equipes multidisciplinares que prestam assistência integral (clínica e psicossocial) aos pacientes; atendimentos ginecológico, pediátrico e odontológico; controle e dispensação de anti-retrovirais e de preservativos; atividades educativas para adesão à Terapia Anti-Retroviral (TARV); atividades educativas para prevenção e controle das DST/Aids e a operacionalização na realização de exames laboratoriais necessários ao monitoramento do tratamento anti-retroviral (Brasil, 2004c, 2007a).

Diante dessa realidade, os serviços de assistência aos portadores do HIV/Aids têm papel fundamental nas práticas assistenciais (ações de prevenção, diagnóstico e tratamento). Esses serviços envolvem tanto os equipamentos, quanto as pessoas - os profissionais de saúde - sendo que é nessa relação que reside à dinâmica dos potenciais de sucesso, ou seja, adoção de comportamentos/atitudes de preservação da qualidade de vida, dentre outros.

Dessa forma, a compreensão desse período de tratamento da criança, 
verticalmente exposta ao HIV, auxiliará a abordagem, pelos profissionais de saúde, dos pais e da família em suas interações.

\subsection{AIDS NO NÚCLEO FAMILIAR}

Aspecto importante do quadro desenhado até o momento é o que envolve diretamente a interação mãe-filho, e, por conseguinte, também o parceiro e pai da criança e, no todo, a dinâmica da família, assunto tratado por vários autores (Lopes, Spindola, 1994; Castro et al., 1997; Boehs, 1999; David, Elsen, 2000; Fullilove R, Green, Fullilove M, 2000; Souza et al., 2000; Ferraz, Stefanelli, 2001; Silveira, Carvalho, 2002; Silveira, 2004; Padoin et al., 2006), entretanto, esses estudos com famílias que convivem com a infecção pelo HIV/Aids têm enfocado os portadores adultos e crianças maiores.

Diante da escassez de textos com a abordagem sobre o lactente, primeiramente discorrerei sobre estudos realizados com adultos na tentativa de uma aproximação com o objeto desta pesquisa.

Estudo realizado, em 1999, com quatro famílias que convivem com HIV/Aids, no meio oeste de Santa Catarina, identificou que a assistência a essas famílias envolve situações nas quais os aspectos éticos mais se evidenciam. O estudo possibilitou observar a força do estigma e do preconceito que são vítimas (David, Elsen, 2000).

Ferraz e Stefanelli (2001), em estudo realizado em Belo Horizonte/MG, com oito membros de um grupo de convivência para portadores do HIV/Aids (cinco homens e três mulheres) e seus familiares, as autoras objetivaram compreender as interações das pessoas adultas que vivem com HIV/Aids no contexto familiar. Os resultados apontaram que os portadores necessitam aprender a viver de novo, conviver com suas oscilações orgânicas e emocionais, com a rejeição dos amigos e dos vizinhos, isto se converte em rotina em sua vida. As autoras puderam evidenciar a importância da atuação dos profissionais de saúde, como elementos de apoio para motivar os portadores a revelarem sua situação a suas famílias.

As implicações sociais do alastramento da epidemia nas mulheres 
foram apresentadas, por meio de uma análise do perfil das mulheres com Aids notificadas ao Centro de Vigilância Epidemiológica, pelo Instituto de Infectologia Emílio Ribas, em São Paulo. Esse estudo apontou que o número significativo de filhos e de familiares infectados pelo HIV, relatados pelas mulheres, permitiu avaliar/estimar o grau de desestruturação familiar, psicoemocional e mesmo financeiro decorrentes dessa situação (Takahashi, Shima, Souza, 1998).

A vivência junto ao ser humano com portador do HIV/Aids e seus familiares foi tema do estudo de Souza et al. (2000) que resultou em dados obtidos com 16 encontros com os sujeitos membros de três famílias, atendidas pelo Serviço de Assistência de Especialidade de Pelotas/RS. Os autores ressaltaram a importância atribuída aos profissionais de saúde ao se prepararem para assistir as pessoas com HIV/Aids e seus familiares, com objetivo de diminuir o medo e o preconceito da doença, bem como respeitar a experiência de vida da pessoa e de sua família no seu contexto.

Em artigo de Contim, Chaud, Fonseca (2005), que trata do enfrentamento da família diante do processo de cuidar da criança e do adolescente com doença crônica, verifica-se que as dificuldades enfrentadas pelas famílias são as mais diversas, enfatizando que as conseqüências do adoecer de qualquer membro do núcleo familiar são devastadoras e desestabilizadoras.

Essas reflexões direcionam os profissionais de enfermagem a compreenderem que a pessoa com aids e sua família adoecem conjuntamente e sofrem todas as ambigüidades e dúvidas dessa experiência de conviver com pessoas acometidas pela doença. Silveira e Carvalho (2002) encontraram resultados coincidentes, pois afirmam que a família é peça fundamental no tratamento e o paciente a quer perto de si, porém enfrenta muitos problemas.

O significado que as mães soronegativas, do Rio de Janeiro, atribuem ao vivenciar a situação de ter um filho adulto portador de aids, numa investigação fenomenológica realizada durante a permanência da mãe como acompanhante, na unidade de internação, permitiu a compreensão do fenômeno, ante relatos de cinco mães com níveis socioculturais diferenciados (Lopes, Spindola, 1994). Esse estudo revelou que, na essência, essas mulheres consideram sua condição: como uma experiência muito triste, muito difícil e de muita expectativa, com um forte sentimento de solidariedade, apesar da negação da doença determinada pelo 
preconceito, como uma experiência somente suportável pela crença em um ser superior. Esses dados são convergentes com os achados de Sherlock, Vieira (1999) e de Moura (2002), que imputam à fé em Deus e à força interior como sustentáculos imprescindíveis para a manutenção da saúde.

Barroso, Miranda, Pinheiro (1998), por sua vez, abordaram a contaminação pelo HIV por mulheres com relacionamento heterossexual estável. Utilizaram enfoque etnográfico e acompanharam o aconselhamento pré e pós-teste para o HIV, de um serviço no Estado do Ceará, durante seis meses, selecionando cinco mulheres para a entrevista semi-estruturada. Os depoimentos dessas mulheres expressaram uma situação difícil como portadoras do HIV, mostraram-se revoltadas com seus companheiros e preocupadas com os filhos, por causa do estigma e também temiam o futuro, pois sua ausência poderia deixar as crianças em situação de insegurança, uma vez que as famílias dessas mulheres não lhes ofereciam apoio.

Esses estudos, sobre famílias e portadores adultos do HIV e sobre crianças com doença crônica, revelaram que, apesar das dificuldades que a aids representa, obrigando doentes e familiares a se confrontarem com questões de difícil convivência, cada família tem potencial de desenvolver forças individual ou grupal, para fazer da experiência uma vivência saudável na busca pela qualidade de vida.

Em pesquisas sobre a interação mãe-filho no contexto da aids, conduzidas por Sherlock, Vieira (1999) e Johnson, Lobo (2001), realizadas, respectivamente, no Nordeste brasileiro e no Sudeste dos Estados Unidos, e direcionadas à interação da mãe e da criança na presença da infecção materna pelo HIV, verificam-se preocupações das mães em relação aos filhos.

No estudo americano, Johnson, Lobo (2001) tinham como propósito descrever e comparar a interação entre mãe e filho, e para tanto compararam dois grupos de 25 binômios cada, cujas crianças tinham idade entre três e vinte e quatro meses, sendo um grupo positivo para o HIV e o outro negativo. Utilizando-se de escalas e metodologia quantitativa, as autoras concluíram que não há diferença estatisticamente significativa na interação da mãe-filho entre os grupos soropositivo e soronegativo, e sugeriram que a infecção materna pelo HIV parece não influenciar a interação mãe-filho.

Enquanto que o estudo brasileiro buscou identificar sentimentos das mães portadoras do HIV/Aids ao vivenciarem a experiência da realização do exame 
sorológico para o HIV do filho. Foram realizadas oito entrevistas com mães cujos filhos estavam em seguimento por instituição especializada, verificando-se algumas características das preocupações maternas relacionadas às relações mãe-filho, à ansiedade, à separação materna, à dúvida, à convivência com a soropositividade e com o preconceito. $\mathrm{O}$ estudo verificou que, ser mãe portadora e ter uma criança que poderá ou não ter confirmada uma doença crônica, expõe o medo, tanto de morrer e deixar os filhos desamparados, propiciando modificações nas rotinas de vida, mas também, ressalta problemas sociais e afetivos ligados à doença da mãe (falta de recursos financeiros, necessidade de cuidado, proteção e afeto do filho). Como conclusão apontaram que o sentimento materno de não poder acompanhar o crescimento e o desenvolvimento de seu filho leva a uma ruptura do vínculo mãefilho ainda em vida (Sherlock, Vieira, 1999).

Conhecer a percepção das mães, acerca das crenças que motivam seus comportamentos, proporciona aos profissionais de saúde maior compreensão desses comportamentos, permitindo-lhes ainda a possibilidade de elaboração de um planejamento mais efetivo de cuidados dentro de um contexto culturalmente significativo (Neves, 2005).

A Enfermagem, atuando diretamente com a área de saúde da mulher, está envolvida com a questão e necessita preparar-se/implementar, juntamente com a equipe de saúde, o enfrentamento desse desafio, participar ativamente da busca de soluções para as transformações que a infecção pelo HIV trouxe para a assistência à saúde da gestante, dos filhos e da família e buscar a promoção de uma integração familiar (Vaz, Barros, 2000; Santos et al., 2002).

\subsection{AÇÕES INSTITUCIONAIS}

Creio ser oportuno, neste momento, acrescentar que o Ministério da Saúde, ao adotar, em 1995, as ações preconizadas pelo Protocolo 076 do ACTG Aids Clinical Trials Group, não eliminou os obstáculos operacionais e profissionais ainda presentes, seja a má qualidade do pré-natal, salientando-se o número elevado de gestantes fora do pré-natal, o início tardio do pré-natal, com o conseqüente retardo 
no diagnóstico e início da medicação, o mau preenchimento dos prontuários médicos, dificultando a tomada de decisões e o alto índice de abandono por parte das gestantes no acompanhamento.

Tais fatores que, aliados à incapacidade dos laboratórios de realizar a testagem de maneira ágil e à atuação precária dos profissionais da equipe de saúde, que demonstram resistência para abordar e solicitar o teste anti-HIV, mantêm uma assistência precária à profilaxia da TMI do HIV. (Brasil, 1999b; Stefani, Araújo, Rocha, 2004; Araújo, Vieira, Bucher, 2006; Praça, Barrancos, 2007).

Esses aspectos denunciam um contexto de baixa qualidade da atenção à gestante, salientam as questões que envolvem o processo de aconselhamento que é inequívoco o envolvimento do profissional da área de saúde, constatados em estudos de Cavalcante et al. (2004), Souza Júnior et al. (2004), Del Bianco, Kuschnaroff, Santos (2005) e Praça, Barrancos (2007), os quais explicitam a necessidade de um preparo que capacite além dos temas específicos, o conhecimento das peculiaridades sobre o HIV/Aids, especialmente o aconselhamento.

Reconhecendo que o alcance das medidas preventivas, oferecidas no pré-natal, voltadas à transmissão vertical do HIV é insuficiente e não impediu que mais de $90 \%$ dos casos de Aids entre os menores de 13 anos, tenham como causa essa categoria de exposição, o Ministério da Saúde criou um projeto com o objetivo de interferir nesses indicadores, bem como no da sífilis congênita e melhorar a qualidade da assistência perinatal.

O projeto denominado "Projeto Nascer-Maternidades" foi lançado em 2000, como uma das estratégias para ampliar o acesso das gestantes ao diagnóstico da infecção pelo HIV. Foi direcionado às maternidades do SUS (próprias e conveniadas), localizadas em municípios considerados prioritários e que atendessem a mais de 500 partos/ano (Brasil, 2003b). As ações integram a capacitação de equipes multiprofissionais em acolhimento, aconselhamento, utilização de testes rápidos, manejo clínico de parturientes HIV positivo e de crianças expostas, testagem e indicação terapêutica para sífilis e vigilância epidemiológica. O Projeto prevê também, para as maternidades cadastradas, o fornecimento dos testes rápidos e de insumos para prevenção e para a profilaxia (AZT, inibidor de lactação e fórmula láctea com provisão para seis meses).

Apesar dos esforços, até 2005, a cobertura do Projeto Nascer- 
Maternidades atendeu apenas a 38,7\% da estimativa anual de 17.200 gestantes HIV positivas, no Brasil, o que representa menos de sete mil tratamentos realizados e mais de dez mil riscos de transmissão vertical não evitados (Brasil, 2004c).

Outra forma de evidenciar o trabalho de prevenção, diante da situação epidemiológica do país, reside no patrocínio, pelo órgão gestor de saúde do país, de ações de visibilidade sobre mulheres e sua vulnerabilidade perante à epidemia, tais como a campanha do Dia Mundial de Luta Contra a Aids, de 2004, que explorou o tema da transmissão vertical do HIV.

O Ministério da Saúde também inovou ao apresentar uma estratégia diferenciada, adequando a campanha às necessidades da população (etnias), contemplando e respeitando as peculiaridades presentes na população brasileira, para facilitar a identificação/incorporação de seu conteúdo em todas as regiões do país. Para reforçar as ações de prevenção da transmissão vertical do HIV, pautadas na situação exposta pelos dados dos estudo-sentinela parturiente realizados em 2002 e 2004, o Ministério da Saúde lançou o Projeto de Implementação da Vigilância da Aids, da Sífilis na Gestação e Congênita, nas Regiões Norte e Nordeste (Brasil, 2005a).

Essas estratégias adotadas pelo Ministério da Saúde, para reduzir a taxa de prevalência da transmissão vertical do HIV, necessitam, porém, de amparo das instâncias municipais de gestão dos serviços de saúde, uma vez que o sistema brasileiro está pautado na diretriz da municipalização das ações de saúde, tornando muito importante a parceria entre o nível federal e o municipal.

Para implementar a melhoria da qualidade da atenção à saúde da mulher e do seu filho, durante a gestação e o puerpério, e vislumbrando o alcance da redução da transmissão vertical do HIV e a eliminação da sífilis congênita, em outubro de 2007, o Ministério da Saúde lançou o Plano para Redução da Transmissão Vertical do HIV e da Sífilis no Brasil, estimulando o cumprimento das ações e das metas propostas, ancoradas nas contribuições e responsabilidades compartilhadas entre os três níveis de governo - federal, estadual e municipal (Brasil, 2007a).

Uma situação que exemplifica essa parceria nos níveis federal e municipal ocorreu em Sorocaba, SP, onde a equipe do Programa Municipal de DST/Aids do Município, preocupada com o número crescente de mulheres e 
gestantes infectadas, buscou recursos e apoio, realizando uma das primeiras parcerias com o Ministério da Saúde, em 1998, para intervir nas taxas de transmissão vertical do HIV. Minha vivência profissional, quando trabalhava na Secretaria Municipal de Saúde dessa cidade, e também como docente da área materno-infantil, aliada à coordenação de um projeto de apoio às mães soropositivas, me proporcionaram contatar com a proposta de trabalho do Município, o que estimulou o interesse pelo objeto deste estudo. 


\section{PROJETO TRANSMISSÃO VERTICAL ZERO}

Como forma de melhor descrever as ações de prevenção da transmissão vertical no município de Sorocaba, SP, local deste estudo, farei uma apresentação do histórico do projeto Transmissão Vertical Zero, norteada por informações documentais do Programa Municipal de DST/Aids, por citações, por reportagens de jornais locais, por memória pessoal e por relatos dos profissionais envolvidos conforme Batista (1999), Sorocaba (1999, 2001) e Programa (2000).

A Secretaria Municipal de Saúde de Sorocaba, em 1997, iniciou ações pontuais com intuito de diminuir a transmissão vertical no Município, sendo estas consolidadas em setembro de 1998, na forma do Programa Transmissão Vertical Zero. O projeto foi implantado com recursos vindos do Ministério da Saúde para a aquisição de kits para realização de testes e compra de medicamentos, e desenvolveu protocolos com estratégias envolvendo centenas de profissionais de saúde.

O referido projeto é desenvolvido pelo Programa Municipal de DST/Aids e sua implantação compreendeu várias fases, com início no treinamento dos profissionais, médicos e enfermeiras, das 27 Unidades Básicas de Saúde (UBS) envolvidas no Programa Saúde da Mulher, concomitante com o treinamento da equipe obstétrica da Maternidade da Santa Casa de Sorocaba, uma das instituições que atendem ao SUS.

Desde seu início, ficou estabelecida a realização de testes anti-HIV para todas as gestantes atendidas nas UBSs, em seguida implementou-se o fluxo da assistência e a garantia de fornecimento de medicamentos para o tratamento às 
portadoras do vírus. Seguiu-se a definição de acompanhamento dos recém-nascidos, filhos de mãe soropositiva, até a confirmação de que não houve transmissão vertical. Esse acompanhamento é realizado no SAE, denominado Clínica DST/Aids.

O projeto estabeleceu, também, para todas as gestantes que buscavam assistência pré-natal na rede municipal de saúde, a oferta de teste anti-HIV voluntário no $1{ }^{\circ}$ trimestre de gravidez, e, desde 2004, o protocolo recomenda que seja realizado um segundo teste no $3 .^{\circ}$ trimestre, ambos acompanhados por aconselhamento pré e pós-testagem.

$\mathrm{O}$ resultado positivo ou indeterminado do teste anti-HIV, indica que a UBS encaminhe a gestante ao COAS para receber o aconselhamento realizado por profissionais de nível universitário qualificado e para a efetivação do exame confirmatório. Detectando a infecção pelo HIV, a gestante é encaminhada para atendimento no SAE - Clínica DST/Aids, iniciando o pré-natal de alto risco.

Esses dados são incorporados na ficha, denominada COAS - Ficha da Gestante - possibilitando a reunião das informações num banco de dados COASGES, no qual todas as gestantes soropositivas para o HIV detectadas têm seus dados registrados.

O acompanhamento da gestante soropositivo prevê a realização da contagem de $\mathrm{CD}_{4}$ (Cluster of Differentiation 4) e de carga viral, bem como a aplicação do protocolo ACTG 076/TARV para profilaxia da transmissão maternoinfantil do HIV. Prevê, ainda, o acompanhamento das gestantes e a articulação com o Programa Recém-Nascido de Risco bem como o encaminhamento das informações das gestantes atendidas para a realização de visita domiciliária, que deve ocorrer por volta da $34 .^{\text {a }}$ semana de gestação, para reforço das orientações e para referência à maternidade.

Desde o início do Projeto, em 1998, já foram atendidas no Programa de Pré-Natal um número aproximado de 41 mil gestantes, e houve cerca de $2 \%$ de recusa do teste; a quantidade de testes anti-HIV, realizados em gestantes, contabiliza aproximadamente 45 mil testes. Vale lembrar que, no segundo semestre de 2004, foi introduzido o segundo teste anti-HIV no terceiro trimestre da gestação. A taxa de prevalência do HIV em gestantes no Município apresenta consistente decréscimo desde 
2000, apresentando em 2005 uma taxa de 0,17\%, enquanto para o Brasil é de $0,41 \%{ }^{5}$.

Por outro lado, o Programa Recém-Nascido de Risco, iniciado em junho de 2000, atende a todas as mães e recém-nascidos de Sorocaba nas maternidades públicas. Dentre suas atividades constam a classificação dos bebês quanto ao risco (biológico e social), as orientações às mães, e o agendamento do binômio mãe-filho para consultas nas UBSs. A equipe de saúde do Programa, formada por neonatologista, enfermeiro, auxiliares de enfermagem, psicólogo e assistente social, presta atendimento especializado na Policlínica para os recémnascidos de alto risco biológico e realiza visita domiciliária a todos os de risco. Nesse trabalho há também a retaguarda de outros especialistas.

Após o parto, as puérperas HIV positivo, atendidas no Projeto Transmissão Vertical Zero são encaminhadas para a Clínica DST/Aids para consulta de puerpério e seguimento dos recém-nascidos por meio de consulta mensal com o pediatra até a definição do diagnóstico.

No município de Sorocaba, o diagnóstico da infecção pelo HIV em crianças segue o cronograma de contagem de carga viral, a partir do $3 .^{\circ}$ mês de vida, e com periodicidade trimestral até os 18 meses, quando será realizado o teste ELISA para confirmação diagnóstica e se negativo ocorre alta do Projeto.

Como um dos municípios pioneiros nesta estratégia de atenção ao binômio mãe-filho, Sorocaba, em 1999, foi contemplada pela Secretaria de Estado da Saúde de São Paulo com uma cota de 60 exames do tipo PCR qualitativo de detecção do HIV, exame utilizado para os bebês de mães soropositivas.

Em outubro de 2007, no mesmo Município, ocorreu o Encontro Municipal para o Enfrentamento da Transmissão Vertical do HIV e da Sífilis Congênita, evento do Programa Municipal de DST/Aids de Sorocaba, que contou com a participação dos profissionais da saúde da Secretaria Municipal da Saúde (SES), para reforçar e avançar na proposta de prevenção a doenças de transmissão vertical, que são consideradas dois desafios da saúde na atualidade. A gestão do programa segue a agenda do PN DST/Aids, reforçado por estudos que identificaram as desigualdades existentes na atenção aos dois problemas e reconheceram a necessária e urgente priorização da sífilis na gravidez (Ramos Júnior et al., 2007).

\footnotetext{
${ }^{5}$ Informação da Planilha "Resultados do PTVZ: período 2000/2005" fornecida pelo Programa Municipal DST/Aids.
} 
Outro aspecto do Projeto Transmissão Vertical Zero é a atuação conjunta com as organizações não-governamentais (ONGs), tais como o Grupo de Prevenção e Apoio à Aids do Município - GEPASO, que até o ano de 2002 era responsável pelo fornecimento de fórmula láctea às crianças expostas verticalmente ao HIV, e que, a partir de 2003, passou a ser de responsabilidade do Município com financiamento do Projeto Nascer do Ministério da Saúde.

Outra ONG, Associação Crianças de Belém ${ }^{6}$, fundada em 1996 com a missão de contribuir para a melhoria da qualidade de vida das crianças e adolescentes soropositivos para o HIV, oferece-lhes atendimento em creche, em abrigo e em escola do ensino fundamental, assim como realiza cursos profissionalizantes e de artesanato destinados às famílias para a geração de renda e, dão-lhes principalmente, apoio psicológico e social aos portadores assintomáticos ou com sintomas causados pelo HIV. Em relação ao apoio domiciliar, fornece-lhe cestas-básicas e acompanhamento médico.

Em 1999, a Associação Crianças de Belém apresentou o projeto, “ $O$ amor que vem da prevenção", com recursos da igreja Presbiteriana Americana, numa parceria com o Programa Municipal de DST/Aids, com o objetivo de apoiar o Projeto Transmissão Vertical Zero, realizando acompanhamento sistemático das gestantes que concordassem em participar dessa estratégia.

Esse trabalho visa a minimizar as carências econômicas com o fornecimento de vale transporte e cesta básica, bem como voltando-se aos aspectos psicossociais e ao suporte para ampliar a adesão ao tratamento profilático com o AZT. Próximo ao parto, há ainda, como propostas, a entrega do enxoval para o bebê e o suporte espiritual, com a doação de uma Bíblia. Esse projeto foi reconhecido como exemplo para fins de financiamento pelo Fundo das Nações Unidas (UNAIDS) no seu relatório, produzido durante a edição de 2002 do Fórum Econômico Mundial, realizado em Nova York (Ortolan, Souza, [200?]).

Esse contexto e a minha atuação profissional, principalmente, quando fui coordenadora do projeto "O amor que vem da prevenção", reforçaram meu interesse em realizar um estudo voltado para a situação familiar durante o período de espera do diagnóstico definitivo para o HIV do filho.

Outro fato importante é a minha experiência como professora das

${ }^{6}$ www.cribelem.org.br 
disciplinas de Enfermagem na Reprodução Humana e Administração em Enfermagem do curso de Enfermagem da PUC-SP, cujas aulas práticas são realizadas, respectivamente, na maternidade do Complexo Hospitalar de Sorocaba e no Ambulatório Regional de Especialidades, onde são atendidas as gestantes soropositivas, de 46 municípios do Departamento Regional de Saúde XVI - (DRS), situação esta que proporciona o contato com a temática da transmissão vertical do HIV, uma vez que a prática docente se dá diretamente com as mães portadoras e recém- nascidos expostos.

Dado o ineditismo, a relevância e abrangência do Projeto Transmissão Vertical Zero na atenção à mulher soropositiva para o HIV e seu filho, e pela carência de estudos que caracterizam a mulher atendida pelo Projeto, pretendo, neste estudo, apontar dados sociodemográficos e de saúde da gestante atendida no referido Projeto, para em seguida compreender sua vivência, e a do parceiro diante da espera do resultado definitivo do teste anti-HIV do filho, por ser este um período crítico para a dinâmica do núcleo familiar. Assim, almejo melhor conhecer as gestantes e contribuir para a compreensão dos fatores que envolvem os pais e os lactentes num contexto de transmissão vertical do HIV, e obter pistas que direcionem os serviços de saúde para as demandas de assistência dessa clientela.

Diante do exposto, com este estudo, pretendo responder às seguintes questões:

- Como a mãe soropositiva para o HIV e o parceiro vivenciam a situação de indefinição do diagnóstico de soropositividade do filho?

- Como ambos convivem com os procedimentos adotados com o bebê enquanto aguardam a confirmação do diagnóstico para soropositividade ao HIV?

- Quais as expectativas da mãe e do pai do lactente diante da possibilidade de soropositividade e de sobrevida do filho?

- Que estratégias ambos desenvolvem em seu cotidiano enquanto aguardam a definição do diagnóstico do filho? 


\section{PRESSUPOSTOS}

Diante disso, esta pesquisa tem os seguintes pressupostos:

Os pais de um recém-nascido exposto ao HIV, cuja mulher é inscrita no Projeto Transmissão Vertical Zero, negam a transmissão do vírus ao filho, porque:

- Acreditam no tratamento dado à mãe durante a gestação e o parto, e ao recém-nascido;

- Têm crença em entidade religiosa.

Os pais citados acima, enquanto aguardam o diagnóstico definitivo do filho, alteram as atitudes e ações do cotidiano em função das necessidades da criança.

Enquanto aguardam o diagnóstico definitivo do filho, estes pais buscam apoio:

- na equipe de saúde;

- nos demais familiares (não nuclear);

- na comunidade religiosa.

Com estes pressupostos, realizei o presente estudo cujos objetivos são apresentados a seguir. 


\section{OBJETIVOS}

Este estudo tem como objetivo geral:

- Compreender a vivência de pais de lactentes expostos ao HIV, cuja mãe é inscrita no Projeto Transmissão Vertical Zero, de Sorocaba, no período de indefinição do diagnóstico para soropositividade ao HIV.

Como objetivos específicos:

- Caracterizar as gestantes atendidas pelo Projeto Transmissão Vertical Zero, de Sorocaba, SP.

- Identificar as ações de mães e pais de lactentes expostos diante da indefinição de seu diagnóstico para soropositividade ao HIV.

- Verificar as expectativas de mães e pais para com o lactente exposto ao HIV que aguarda a definição do diagnóstico.

Para alcançar os objetivos, este estudo quanti-qualitativo foi realizado em dois momentos. No primeiro, constituiu-se em um estudo descritivo, exploratório e retrospectivo, cuja abordagem quantitativa foi realizada com informações contidas 
no Banco de Dados do Projeto Transmissão Vertical Zero da Prefeitura Municipal de Sorocaba, SP.

No segundo momento foi empregado o método qualitativo de pesquisa que teve como referencial teórico a Antropologia Médica e como referencial metodológico a Narrativa. 


\section{PRINCÍPIOS ÉTICOS}

A coleta de dados iniciou-se após aprovação pelo Comitê de Ética em Pesquisa da Escola de Enfermagem da USP, sob n. ${ }^{\circ}$ 499/2005/CEP-EEUSP, em 10/01/2006 (ANEXO 1).

Para realizar a primeira fase do estudo utilizou-se o Termo de "Compromisso de Realização de Pesquisa", devidamente autorizado pela Coordenadora do Programa Municipal de DST/Aids (ANEXO 2), ao qual o Projeto Transmissão Vertical Zero e a Clínica de DST/Aids estão subordinados.

$\mathrm{Na}$ segunda fase, atendendo à Resolução 196/96 do Conselho Nacional de Saúde, o Termo de Consentimento Livre e Esclarecido (APÊNDICE 1) foi apresentado aos sujeitos do estudo para concordância na participação; foi elaborado em duas vias sendo que uma ficou com os entrevistados e a outra com a pesquisadora. Foi também solicitada sua autorização para fotografar as montagens elaboradas e para gravar em fita cassete e gravador digital a interpretação dada pelos informantes. 


\section{O CENÁRIO DO ESTUDO}

Relembro que um dos motivos que direcionou a escolha do local deste estudo foi minha participação no projeto "O amor que vem da prevenção", desenvolvido em 1999, pela ONG, Associação Crianças de Belém, projeto complementar ao Projeto Transmissão Vertical Zero da Prefeitura Municipal de Sorocaba, SP.

Esse contato possibilitou-me discutir as situações que envolvem a transmissão materno-infantil do HIV, bem como propiciou meu maior envolvimento com a equipe do Programa Municipal de DST/Aids daquele Município.

Conforme explicitado anteriormente, este estudo foi realizado no município de Sorocaba, cuja população abrange 600 mil habitantes, e apresenta taxas significativas de transmissão de HIV/Aids, sendo a 21. a cidade em casos da síndrome, no país, em 2004, conforme dados do Ministério da Saúde (Brasil, 2004c).

Nessa cidade, o Programa Municipal de DST/Aids está estruturado em duas unidades, COAS e Clínica de DST/Aids na qual as ações de prevenção, de diagnóstico e de tratamento são desenvolvidas por equipe multiprofissional.

Relembro que a demanda espontânea das gestantes ocorre na rede básica de saúde do Município, pelo Programa de Pré-Natal, no qual é oferecido o teste anti-HIV universal às gestantes. Ao ser detectada a soropositividade, a gestante é inscrita no Projeto Transmissão Vertical Zero e encaminhada ao Serviço de Pré-

natal de alto risco para acompanhamento especializado e tratamento, segundo o protocolo ACTG 076 e TARV (Terapia Anti-Retroviral), na Clínica de DST/Aids. 


\section{DESCREVENDO A COLETA E O TRATAMENTO DOS DADOS}

Este estudo, conforme dito anteriormente, foi realizado em dois momentos. No primeiro momento teve como população as gestantes soropositivas ao HIV, atendidas pelo Projeto Transmissão Vertical Zero do município de Sorocaba, SP, no período de setembro de 1998 a dezembro de 2004.

No âmbito do Município, essas informações estão sistematizadas e reunidas no Banco de Dados - COASGES.

No segundo momento, a coleta, o tratamento e a análise dos dados seguiram o método qualitativo de pesquisa.

\subsection{PRIMEIRO MOMENTO - MÉTODO QUANTITATIVO}

Após obter a aprovação do Comitê de Ética em Pesquisa da Escola de Enfermagem da USP (ANEXO 1), os procedimentos para coleta de dados foram os seguintes:

Obtenção da autorização das coordenadoras do Projeto Transmissão Vertical Zero e do Programa Municipal de DST/Aids, de Sorocaba, SP, para disponibilização das informações contidas no Banco de Dados - COASGES de modo a caracterizar as gestantes e favorecer o posterior contato com as clientes (ANEXO 3). 
Registro no instrumento de coleta de dados (APÊNDICE 2), das informações do Banco de Dados - COASGES, reunidas no Programa Epi Info ${ }^{\mathrm{TM}}$, para compilação e tratamento.

Para esta primeira fase do estudo, considerei os dados das gestantes diagnosticadas como positivas ou indeterminadas ao primeiro teste anti-HIV e encaminhadas pelas UBSs de Sorocaba, SP, ao COAS, para a realização de exame confirmatório.

O instrumento de coleta de dados (APÊNDICE 2) foi preenchido com as informações das gestantes soropositivas para o HIV e matriculadas no Projeto Transmissão Vertical Zero do município de Sorocaba, cujos registros encontravamse no instrumento de coleta de dados denominado "COAS - Ficha de Gestante" (ANEXO 3), abrangendo o período de setembro de 1998 a dezembro de 2004, sistematizadas e reunidas no Banco de Dados - COASGES.

As informações registradas nesta ficha foram feitas pelo profissional que atendeu à gestante e lançadas no banco de dados pelo funcionário da Instituição.

O instrumento de coleta de dados deste estudo foi elaborado com base nas variáveis do banco de dados - COASGES, que apresenta 30 itens, dentre os quais, optei por coletar e analisar os dados sociodemográficos da gestante: idade, escolaridade, ocupação, renda familiar, estado civil e número de filhos; dados relacionados à transmissão do HIV, percepção de risco, fatores de exposição e situação sorológica do parceiro, e dados sobre práticas sexuais, número de parceiros, uso de preservativo e orientação sexual. Os dados foram registrados conforme constam na "COAS - Ficha da Gestante".

\subsubsection{População/Amostra}

Do banco de dados foram consideradas somente as fichas que se encontravam completas em relação às respostas das gestantes. Dessa forma, de uma população de 128 respondentes, a amostra constou de 120 gestantes. Devo destacar que esse banco de dados encontra-se incompleto, pois o número estimado é de 196 gestantes inscritas no Projeto Transmissão Vertical Zero. 
Ademais, o próprio instrumento de dados da Instituição, quando auditado teve recomendações no sentido de ser reformulado devido à falta de clareza em alguns itens (Souza, 2005).

\subsubsection{Tratamento dos Dados}

Para esta fase do estudo, o formulário de coleta de dados (APÊNDICE 3) foi preenchido por mim, lançado em banco de dados do Programa SPSS $^{\circledR}$ (Statistical Package for the Social Sciences), tabulado e analisado estatisticamente, sendo estimados freqüência e média e intervalo de confiança quando pertinente.

\subsection{SEGUNDO MOMENTO - MÉTODO QUALITATIVO}

Com os dados quantitativos em mãos e ao identificar as mulheres atendidas no Projeto Transmissão Vertical Zero, parti para a realização do segundo momento desse estudo.

Este momento requer referenciais teórico e metodológico, apresentados a seguir.

\subsubsection{Referencial Teórico}

Ao considerar a natureza da temática em questão, que trata da compreensão da vivência da mãe e do pai diante da indefinição do diagnóstico do filho exposto ao HIV, e com base em Minayo (2000), a segunda fase do estudo foi realizada com o emprego do método qualitativo.

Uma das características da pesquisa qualitativa é fornecer ao 
pesquisador a possibilidade de captar a maneira pela qual os indivíduos pensam e reagem ante as questões focalizadas, também auxilia na compreensão dos sentimentos, dos valores, das atitudes e dos temores das pessoas, explicando suas ações diante de um problema ou situação (Uchôa, Vidal, 1994; Merighi, Praça, 2003).

Ao almejar conhecer o significado das "coisas", reconhecidas como fenômenos, manifestações, ocorrências, fatos, eventos, vivências, idéias, sentimentos e assuntos, o interesse do pesquisador encaminha-se para entender o sentido que as pessoas atribuem a essas "coisas". Considera-se que o significado tem função estruturante na vida das pessoas, tem um papel organizador em suas vidas, que inclui seus próprios cuidados com a saúde, e ao ser compartilhado culturalmente traz conseqüências, que refletem no grupo social (Turato, 2005).

$\mathrm{Na}$ Enfermagem, as pesquisas qualitativas iniciaram-se na década de 1970, com a característica diferencial dos estudos que até então eram produzidos. Sua natureza holística e descritiva, baseada em significações, favorece o aprofundamento do significado das crenças e dos valores dos indivíduos; permite, ainda, compreender os significados das ações e das relações humanas (Merighi, Praça, 2003).

A Enfermagem tem utilizado a metodologia qualitativa de forma a explorar as situações da assistência que presta às pessoas, buscando melhor compreender o significado das experiências relativas ao processo saúde-doença, e dessa forma compreender a vida dos pacientes (Alonso, 2003).

Nessa perspectiva, este estudo foi norteado pelo referencial teórico da Antropologia Cultural, com enfoque na área que envolve o processo saúde-doença e as práticas de saúde, ambos inseridos na Antropologia Médica. Assim, terei a possibilidade de compreender a dinâmica do fenômeno e os relacionamentos presentes na cultura, o que me permitirá prestar cuidado culturalmente embasado, com possibilidade de intervenções mais adequadas à clientela (Praça, Gualda, 2001; Alonso, 2003; Silva V, 2005).

Vale acrescentar que, ao estudar um grupo de seres humanos, é necessário conhecer as características tanto da sociedade quanto de sua cultura. A formação cultural influencia muitos aspectos da vida das pessoas, inclusive suas crenças, comportamentos, percepções, emoções, linguagem, religião, rituais, estrutura familiar, dieta, modo de vestir, imagem corporal, conceitos de tempo e de 
espaço e atitudes diante da doença. Cada cultura possui uma lógica interna que norteia as suas práticas relativas ao processo saúde-doença (Hoga, 2003; Raynault, 2006).

Existem várias definições de cultura, elaboradas pelos autores pesquisados como Geertz (1989), Helman (2003) e Gualda, Bergamasco (2004). Minha opção recai sobre a que melhor se adapta a este estudo, que é a concepção de Helman. Para este autor, a cultura expressa um conjunto de princípios (implícitos e explícitos) herdados por indivíduos membros de uma dada sociedade, princípios estes que mostram aos indivíduos como ver o mundo, como vivenciá-lo emocionalmente e como comportar-se em relação às outras pessoas, às forças sobrenaturais ou aos deuses e ao ambiente natural. Uma lente herdada para que o indivíduo perceba e entenda o seu mundo e para que aprenda a viver nele.

A Antropologia Cultural atua em várias áreas do conhecimento. Quando envolve o processo saúde-doença e as práticas de saúde fala-se em Antropologia Médica, que, segundo a definição do antropólogo inglês Cecil G. Helman (Helman, 2003, p. 11),

\footnotetext{
aborda as maneiras pelas quais as pessoas, nas diferentes culturas e grupos sociais explicam as causas dos problemas de saúde. Relaciona-se, também, aos tipos de tratamento nos quais as pessoas acreditam e aos indivíduos a quem recorrem, quando, de fato, adoecem. Também, é o estudo de como essas crenças e práticas estão relacionadas com as mudanças biológicas e psicológicas no organismo humano, tanto na saúde quanto na doença.
}

No Brasil, os estudos com esta abordagem enquadram-se na especialização que constitui a Antropologia da Saúde/Doença (Canesqui, 2003), a qual vem alcançando visibilidade e maior legitimidade acadêmica, especialmente, a partir da década de 1970. Seus estudos destacam-se nos temas relacionados aos hábitos e às ideologias alimentares, e em análises eventuais sobre as concepções do corpo e as curas religiosas (Canesqui, 1994). Seus pesquisadores estão presentes nos ambientes das ciências biomédicas, na saúde pública, na psiquiatria, na ginecoobstetrícia e na pediatria, e também nas ciências sociais e humanas. Há uma procura pela interdisciplinaridade, principalmente, na década de 1990, no sentido de estudar a construção das pessoas, do corpo ou das emoções, associada aos fenômenos da "doença" ou perturbações. 
Partindo dessas concepções, a visão integrada do ser humano como uma totalidade biocultural e psíquica, na qual os termos mantêm uma relação dialética, possibilitará compreender o processo saúde-doença e abordar as maneiras pelas quais as pessoas, em diferentes culturas e grupos sociais, explicam as causas dos problemas de saúde (Helman, 2003).

Neste contexto, a enfermeira necessita conhecer as similaridades e diferenças do cuidar cultural e, para tanto, deve reconhecer que a Enfermagem faz parte de um sistema cultural, com determinada organização e lógica de saberes, e que interage com pessoas em um determinado momento na sua experiência de estar saudável ou doente, a fim de atingir seu objetivo e contribuir efetivamente na qualidade da assistência à saúde (Alonso, 2003; Raynault, 2006).

Uma das tarefas da Antropologia Médica, portanto, é estudar o modo como as pessoas, em determinada sociedade, percebem e reagem à falta de saúde e aos tipos de assistência que elas procuram. Sua maior contribuição para o conhecimento e a compreensão do fenômeno saúde-doença é a insistência que o agir humano é culturalmente moldado e constituído em relação às formas distintas de vida e de organização social (Helman, 2003).

Em vista do objeto deste estudo, que envolve a interação entre pai, mãe e filho, utilizei o conceito de família proposto por Helman (2003), no qual entende família, como uma unidade bio-sócio-cultural, constituída de pessoas ligadas por laços afetivos ou consangüíneos que interagem entre si. Complemento este conceito com perspectiva dada por Contim, Chaud, Fonseca (2005), que consideram a família como uma unidade primária de cuidado, pois ela é o espaço social onde seus membros interagem, trocam informações, apóiam-se mutuamente, buscam e mediam esforços, para amenizar e solucionar problemas.

\subsubsection{Referencial Metodológico}

Um problema é estudado, muitas vezes, mediante o uso de diversas técnicas qualitativas, as quais são encontradas em uma "caixa de ferramentas" que contém vários dos métodos de coleta de dados. Entender o papel das crenças e dos comportamentos ligados à saúde exige uma abordagem holística e multidimensional 
(Helman, 2003).

A Narrativa foi o referencial metodológico adotado para organizar e apresentar os dados desta segunda fase do estudo. Ela é uma forma universal encontrada em todas as culturas, por meio das quais as pessoas expressam suas percepções, sua visão de mundo, e as maneiras de interpretar os acontecimentos (Silva, Trentini, 2002; Tronchin, Tsunechiro, 2006). Como técnica de pesquisa tem sido utilizada no âmbito da Antropologia da Saúde como acesso à experiência do adoecimento das pessoas (Lira, Catrib, Nations, 2003).

A Narrativa permite a construção de um conhecimento alicerçado no relato da experiência das pessoas sobre uma realidade vivencial, que possibilita à pessoa reorganizá-la, selecionando os componentes significativos, de modo que tenha uma ordem coerente e que melhor retrate esse evento, provocando uma revisão de metas de vida (Wernet, 2007). Ao fazer essa restituição, a pessoa esboça um esforço para a restauração da própria identidade, pois a doença é uma ruptura da rotina de vida.

Consequentemente os envolvidos em tal situação procuram uma transformação, para permitir reconduzir as ações da vida cotidiana, podem igualmente, descrever uma situação que não podem melhorar, limitando a perspectiva de mudança. A doença se torna um contexto dentro do qual o resto de vida pode ser avaliado, precipitar crises de identidade, e requerer negociação da pessoa com a família, amigos e a sociedade em geral (Blaxter, 2004).

Na Narrativa, a característica essencial é que haja um enredo: um passado, presente e futuro. Segundo Blaxter (2004), esta sucessão temporal é o que assegura o significado aos eventos que se espalham no tempo, para que uma aparente sucessão de fatos aleatórios se torne um todo lógico.

Enfatizando, as pessoas, ao narrarem sua vivência, abrem seu discurso de modo a permitir a apreensão de seu significado por outras pessoas e o acesso a essa vivência, porém, de modo indireto; pois, a pessoa relata a maneira como percebeu a doença, ou melhor, como a interpretou (Silva, Trentini, 2002).

Por outro lado, as estratégias mais recentes para coleta de dados em pesquisa são elencadas por Helman (2003): uso de questionários abertos, procedimentos de avaliação rápida, grupos focais, listagem livre, classificação por agrupamento, ordenação hierárquica, análise de rede semântica, entrevistas 
familiares, coleção de narrativas, coleta de folclore médico, exame de material escrito ou visual, vídeos ou gravações, genealogias e genogramas, análises de redes sociais, mapeamento e modelagem, técnicas de projeção, vinhetas estruturadas, etnografias de instituições médicas, de curandeiros populares, tradicionais ou "alternativos" e análise computadorizada.

Dentre esse rol de técnicas, escolhi a técnica projetiva como ferramenta para acessar os dados, facilitando a comunicação oral dos colaboradores, pois permitiu o acesso às informações, além de compreender o mundo vivido dos pais soropositivos de forma mais abrangente, integrando a dimensão biológica com outras esferas de saberes, de crenças e de ações, que influenciam as interpretações de sua experiência no processo de adoecimento.

As técnicas projetivas como colagens, desenhos, Rorschach e outras são consideradas formas de comunicação indireta, especialmente, facilitadoras no trabalho com crianças e adolescentes, em que a comunicação verbal direta nem sempre se mostra suficiente para a obtenção do material necessário para a coleta de dados. Estas técnicas são em geral lúdicas e permitem o acesso às fantasias, aos desejos, aos impulsos, aos afetos, aos conflitos, às ansiedades e às defesas que estariam sendo expressas de forma indireta por meio destas técnicas (Trinca, 1997).

O interesse do pesquisador, quando se encontra diante de uma técnica projetiva de alguém, recai sobre a visão subjetiva que o sujeito tem de si mesmo e de seu ambiente, do que ele considera importante, do que enfatiza e do que ignora (Hammer, 1991). A projeção é um mecanismo universalmente utilizado para expressar conteúdos internos, como sentimentos, impressões, medos e outros.

Uma técnica projetiva é um instrumento sensível a aspectos inconscientes do comportamento, que abrange e estimula uma variedade de respostas no sujeito (Retondo, 2000; Miranda et al., 2005), por exemplo, o desenho é uma das formas de comunicação mais antigas, sendo inclusive anterior à linguagem escrita. $\mathrm{O}$ autor ressalta que a técnica projetiva permite-nos perscrutar o inconsciente e inferir características de sua personalidade, pois, por meio dela, a pessoa nos mostra seus sentimentos e conflitos.

Ainda, segundo Retondo (2000), a figura humana é, assim, um veículo de expressão dos aspectos mais conscientes e de suas relações com o meio. Além do eu físico (auto-retrato físico), o sujeito pode projetar no desenho um quadro 
do eu psicológico (auto-retrato psicológico).

A vantagem de empregá-la decorre da possibilidade de sua utilização e aplicação, facultando a articulação entre desenho/colagem, atividade e linguagem. Constituindo, por si mesmo, uma manifestação discursiva e, por conseqüência, uma forma de comunicação (Miranda, Furegato, 2002).

Vale ressaltar que a técnica projetiva considera as formas de comunicação indireta como facilitadoras do trabalho em que a comunicação verbal direta nem sempre se mostra suficiente para a obtenção do material necessário para a coleta de dados. Possibilita a transformação da imagem em linguagem, dando ao objeto uma explicação, um contexto compreensível (Folle, Geib, 2004; Farias, Furegato, 2005).

Neste estudo, ela foi utilizada como meio de facilitar a expressão do pensamento dos colaboradores que discorreram sobre o significado das montagens elaboradas a partir de uma questão norteadora.

Essa técnica tem sido utilizada em estudos das mais diversas áreas, principalmente, abordando questões sobre saúde (Lemos, 2002; Miranda, Furegato, 2002; Andrade, 2003; Gotardo, 2003; Pereira, 2003; Folle, Geib, 2004; Gramacho, Bacarji, 2004; Silva, 2004; Farias, Furegato, 2005), e a temática que envolve a aids, tem buscado nessa abordagem amparo para as pesquisas, como os estudos de Aversari, Castro T, Castro P (1999) e Fioroni, Figueiredo (2000).

As experiências emocionais poderão ser projetadas durante a construção da atividade estimulada/solicitada. A técnica permite uma investigação sobre a projeção de conteúdos psíquicos internos, expressão de sentimentos, o que favorece a assimilação da nova realidade e a elaboração das vivências traumáticas (Gramacho, Bacarji, 2004).

Para este estudo, utilizei a técnica projetiva denominada "Desenhos e Estórias com Tema" desenvolvida por Trinca, como estratégia dos métodos projetivos. Trata-se de uma técnica de investigação que tem por base o uso de desenhos livres e o recurso do contar histórias, constitui instrumento com características próprias para a obtenção de informações na perspectiva que o indivíduo tem sobre algum objeto ou fenômeno. Esta estratégia possibilita a manifestação gráfica de um elemento sugerido, cuja idéia expressa por meio do desenho, que vem carregado de elementos significativos (Trinca, 1997). 
Esta técnica foi utilizada neste estudo para facilitar a coleta de dados. Por tratar-se a aids de tema de difícil expressão, dada à complexidade de sentimentos envolvidos, optei por utilizar a colagem, em substituição ao desenho para obter resposta à questão norteadora. Em seguida, solicitei que a montagem criada fosse descrita para que a narrativa resultante fosse analisada.

\subsubsection{Trajetória da Coleta de Dados}

Neste segundo momento, pesquisaram-se pais e mães com filho lactente exposto ao HIV, sem diagnóstico definido, e cuja mulher HIV positivo estava matriculada no Programa Transmissão Vertical Zero.

As mães foram escolhidas entre aquelas com registro no banco de dados - COASGES que atendiam aos critérios de inclusão nesta pesquisa, que foram definidos como: mulheres inscritas no Programa Transmissão Vertical Zero, desde a gestação; pai biológico da criança exposta; mãe e pai maiores de 18 anos; mãe e pai que não apresentassem debilidade física, e mãe e pai com filhos sem diagnóstico definido para o HIV e com idade entre três e seis meses de vida, considerando que esse período é o estabelecido para a realização dos testes pelo Projeto.

O trabalho de campo foi essencial para desenvolver a pesquisa, característica de estudos qualitativos, que tem o ambiente natural como fonte direta dos dados e o pesquisador como instrumento chave da pesquisa. Minha entrada no campo ocorreu após contato com a responsável pelo Projeto Transmissão Vertical Zero e pela coordenação do Programa Municipal de DST/Aids, responsável pela gestão da Clínica de DST/Aids, local do estudo.

Após a autorização da coordenação, fiz os primeiros contatos com o pessoal da clínica, apresentei o projeto ao coordenador do serviço e pactuei as estratégias para a realização da pesquisa: minha constante presença e a efetivação das entrevistas com os clientes. Dessa forma contatei a enfermeira, os pediatras, a ginecologista, os dentistas e a equipe de enfermagem e recepcionistas; todos me receberam cordialmente e se dispuseram a colaborar no desenvolvimento das atividades. $\mathrm{O}$ aspecto facilitador dessa recepção foi meu entrosamento com a equipe, 
dado o trabalho anterior no projeto embrião do atual, e o local já ter sido referência para outros estudos, como uma dissertação de mestrado (Vicentino, 2005), que estudou a realidade das gestantes que vivem com HIV no município de Sorocaba, SP.

Iniciei, assim, minha observação do ambiente, sem o propósito de descrevê-lo, mas, de interagir em sua dinâmica para favorecer a vinculação com os informantes em potencial, portanto, passei a conviver com as pessoas e as atividades do local.

A coleta de dados, nessa fase, ocorreu no período de fevereiro a novembro de 2006, com as gestantes e mães soropositivas para o HIV, atendidas na Clínica de DST/Aids, que realizavam o pré-natal de alto risco do Projeto Transmissão Vertical Zero. Seus parceiros, pais de seus filhos, também foram convidados a participar da pesquisa.

Para acompanhar o atendimento das gestantes e favorecer meu trabalho, elaborei uma planilha, com base nos dados do Livro de Registro das Gestantes com DST, destacando as mulheres soropositivas para HIV. Nesta planilha registrei: número de ordem, data provável do parto, número de matrícula, nome e idade da mãe, identificação da DST, UBS originária, tratamento, data de nascimento, número de matrícula e nome do recém-nascido e uma coluna para observações e anotações sobre o pai da criança.

Para o rastreamento das mulheres, organizei um calendário semanal referente ao seu comparecimento à clínica, a partir do agendamento para consulta com a ginecologista, no qual especificava as consultas de pré-natal e puerperal, também consultei a agenda da médica pediatra.

Este acompanhamento possibilitou o contato com as gestantes e mães na Clínica Municipal de DST/Aids, com o intuito de favorecer a formação do vínculo entre mim e a família, e ainda de possibilitar a abordagem do pai da criança.

Ao analisar os dados registrados na planilha, percebi a necessidade de alteração do critério de inclusão "pai biológico soropositivo para o HIV", pois constatei alguns pais soronegativos, o que me levou a substituir o critério anterior por "pai biológico do RN".

Ao retomar o banco de dados - COASGES, na Instituição, com as características das mulheres inscritas no Projeto Transmissão Vertical Zero, desde 1998, constatei que, em fevereiro de 2006, havia 31 gestantes inscritas, com previsão 
de nove nascimentos para o primeiro semestre daquele ano. $\mathrm{O}$ acompanhamento das consultas com a pediatra foi realizado com cinco crianças nascidas entre dezembro de 2005 e janeiro de 2006.

Com o contato inicial, passei a freqüentar a clínica quase todos os dias, tanto no período da manhã como à tarde, quando ocorriam as consultas de pediatria. Minha presença era importante para a identificação, pelos usuários e pelos profissionais, estimulando a interação com a equipe e gerando empatia com as mulheres, estabelecendo confiança e criando um clima amigável e acolhedor.

Nesta fase do estudo, portanto, passei a freqüentar a clínica constantemente. Seus médicos, juntamente com as auxiliares de enfermagem, apresentavam-me às gestantes/mães e solicitavam a autorização para eu acompanhar cada consulta. Esse contato, somado àquele realizado em sala de espera, possibilitoume formar vínculo com as mães e pais da criança exposta.

Ao contatar a mulher em sala de espera e/ou na consulta de pré-natal ou de pediatria, expunha os objetivos da pesquisa e convidava a gestante e seu parceiro, companhia freqüente, para participarem do estudo. Diante da concordância de ambos, participava das consultas de retornos mensais tanto de puerpério, quanto de pediatria, e explicava o estudo para a dupla mãe-pai, para que tomassem ciência das estratégias adotadas para desenvolvê-lo, além de informar sobre a assinatura do Termo de Consentimento Livre e Esclarecido.

As entrevistas foram agendadas, por opção do binômio mãe-pai, antes ou após a consulta da mãe ou do lactente, na Clínica de DST/Aids no período estipulado para as coletas de carga viral do bebê.

Com minha permanência no campo, observei que outras atividades, como retirada gratuita de medicamentos e de latas de leite, bem como a coleta de material para exames laboratoriais poderiam ser momentos a ser contemplados para contatar as mulheres, com o objetivo de aproveitar todas as oportunidades da presença das mães na clínica. Desse modo, também consultei as agendas desses serviços e anotei, no meu calendário semanal, as datas em que provavelmente a mulher compareceria e eu poderia contatá-la.

Esse acompanhamento mostrou-me que não seria fácil coletar os dados, devido à ocorrência de imprevistos nesse período, tais como: a morte de um recém-nascido; uma das mães contatadas não havia realizado as consultas de pré- 
natal na clínica; portanto, não atendeu a este critério de inclusão no estudo, embora manifestasse interesse em participar desta pesquisa; ausências aos agendamentos de rotina; transferência de moradia para outra cidade; recusa em participar e limitação intelectual materna.

Vale ressaltar que houve situações em que a consulta estava agendada, mas a mãe não comparecia e retornava em outro dia, que eu desconhecia, portanto, sem agendamento. Quando ocorre alguma falta ou evasão, o Programa Transmissão Vertical Zero, por ser prioritário, na clínica, valoriza todas as oportunidades da presença da mãe e bebê na clínica e "encaixam" a criança para consulta no mesmo dia.

Passei, então, a incluir no meu calendário semanal, além das consultas agendadas para a criança, também as da mãe e as do pai se soropositivo, e constantemente examinava a agenda de exames para vislumbrar oportunidade de coletar os dados.

Assiduamente consultava o Livro de Registro das Gestantes com DST e também recebi ajuda da auxiliar de enfermagem designada para acompanhar as consultas de ginecologia e de pré-natal, que me comunicava sempre que uma nova gestante era cadastrada. De maneira geral, toda a equipe colaborou com a minha atuação na clínica, mas o contato maior foi com as auxiliares de enfermagem.

Consegui acompanhar as consultas da maioria das gestantes e das crianças expostas verticalmente, com potencial de serem sujeitos do meu estudo.

A primeira dinâmica realizada com uma dupla mãe-pai ocorreu por ocasião do agendamento da criança por ocasião da coleta de material para a primeira carga viral. Seu resultado compôs o estudo piloto desta pesquisa e possibilitou-me avaliar o alcance dos objetivos propostos e da abrangência e clareza do instrumento de coleta de dados (APÊNDICE 2) e da questão norteadora.

Vale acrescentar que o citado instrumento continha dados referentes a ambos os pais, para sua caracterização, e alguns de seus dados foram coletados do banco de dados do COASGES $2^{a}$ fase (APÊNDICE 3 ).

No primeiro semestre de 2006, realizei nove dinâmicas e no segundo semestre, foram quatorze.

A delimitação do universo de pesquisados deu-se em razão da qualidade e do grau de recorrência das informações obtidas, pois em estudos 
qualitativos, enquanto estiverem aparecendo "dados" originais ou pistas que possam indicar novas perspectivas à investigação em curso, as entrevistas continuam sendo realizadas (Duarte, 2002).

As dinâmicas/entrevistas foram realizadas até que os dados coletados começaram a se repetir e evidenciaram sua consistência. Desse modo, fui rareando a abordagem às gestantes com datas previstas para o parto, a partir de agosto, pois, postergaria a coleta. Assim, a interrupção da coleta ocorreu de forma suave, a medida que não cadastrava as gestantes matriculadas, e passei a comparecer à clínica com menor freqüência, não percebendo com intensidade o afastamento do campo. A última dinâmica ocorreu em novembro de 2006. Ao final desse ano voltei agradecer a todos a acolhida que tive durante a minha estada e passei a me concentrar à análise dos dados. Minha saída do campo foi facilitada pelo período propício a congratulações característico das festas de final de ano.

\subsubsection{Falando sobre a dinâmica}

Dentre os casais que participaram do estudo, apenas um preferiu que a coleta de dados fosse realizada em sua casa, para favorecer a participação do pai do bebê.

Precedendo a dinâmica proposta, todos os participantes do estudo, pais e mães, eram relembrados dos objetivos da pesquisa, momento em que assinavam o Termo de Consentimento Livre e Esclarecido.

A dinâmica proposta para coleta de dados, com duração aproximada de 30 minutos, ocorreu em dois momentos com cada dupla mãe-pai: o primeiro momento, por volta dos três meses, e o segundo aos cinco meses de vida do bebê. Estes períodos foram considerados levando-se em conta as fases de coleta de exames para contagem de carga viral do lactente.

Dessa maneira, a primeira dinâmica ocorria, após a primeira coleta de sangue, porém sem o conhecimento do resultado. O segundo contato ocorria após a segunda coleta de amostra de sangue, porém ainda sem o conhecimento deste resultado. 
Vale relembrar que, diante de dois resultados negativos de exame de contagem de carga viral, o diagnóstico definitivo de criança exposta, mas não infectada será dado somente após 18 meses de vida.

Como dinâmica, entenda-se a abordagem na qual eram explicadas as atividades que seriam desenvolvidas por ambos os pais, aplicação do instrumento para caracterização dos informantes (APÊNDICE 3), realização da técnica projetiva denominada "Desenhos e Estórias com Tema" quando lhes era dada a opção por uma montagem (colagem em cartolina das figuras escolhidas), e finalmente, a gravação em áudio da narrativa do significado da colagem montada.

Para montar a colagem, após o registro dos dados para caracterização dos informantes, o material para confecção da montagem (cartolina, revistas com conteúdos/temas diversificados, canetas coloridas, tesouras e cola) era deixado à disposição do binômio mãe-pai. Ambos folheavam as revistas buscando figuras que melhor representassem a resposta para a questão:

\section{Como tem sido para você viver o dia-a-dia aguardando o resultado final do teste anti-HIV do bebê?}

Para elaborar a tarefa, alguns pais foram rápidos, outros mais reflexivos, alguns verbalizavam o não-entendimento da tarefa, dessa forma, as recomendações eram repetidas. Na maioria das vezes, a criança e alguns irmãos acompanharam essa dinâmica. A partir da montagem elaborada, foi solicitado ao pai e à mãe a narração/relato de qual sentido atribuíam à construção. Essa fase de inquérito posterior à montagem, variou entre as mães e pais, alguns falando imediatamente, outros necessitaram ser estimulados pela pesquisadora, tendo o gravador ligado para o registro dos relatos.

É importante ressaltar que, antecedendo a gravação das narrativas, foram registrados os dados de identificação dos entrevistados, a data e o local da gravação (Medina, Takahashi, 2003), bem como na cartolina para a montagem. 


\subsubsection{O Tratamento dos Dados}

O tratamento dos dados coletados por meio da dinâmica proposta iniciou-se com a transcrição das narrativas e ocorreu concomitante a cada dinâmica realizada, executando as fases de coleta e de organização de dados simultaneamente. A maioria das interações ocorreu no período da manhã, dessa forma, procurei transcrever as gravações no mesmo dia, para não perder as impressões e poder contar com a memória no momento de ouvir os relatos, para a transcrição literal.

Essa atividade é densa e marcada pelo trabalho próprio de ouvir, escrever, dispor e transformar os dados empíricos, pois à medida que as perguntas vão sendo feitas por várias vezes, para diferentes pessoas, em circunstâncias diversas, e passamos a ouvir nossa própria voz nas gravações realizadas, é que se torna possível avaliar criticamente nosso próprio desempenho e ir corrigindo-o gradativamente (Duarte, 2002).

O conteúdo de cada depoimento foi digitado e organizado em arquivos. Cada montagem foi fotografada e as imagens digitalizadas também arquivadas, juntamente com minhas impressões sobre cada situação vivenciada com os informantes, acrescidas de seus dados pessoais, obtidos também em encontros anteriores à realização das dinâmicas e pela leitura dos prontuários dos bebês expostos, de seus pais e mães que participaram do estudo.

Os dados coletados no campo, a imagem/gravura, resultado da colagem/montagem e a entrevista (relato) constituíram os meios para identificar as ações e as expectativas de mães e pais, na busca pela compreensão da vivência desses pais de lactentes atendidos pelo Projeto Transmissão Vertical Zero, de Sorocaba, diante da indefinição do diagnóstico de soropositividade para o HIV do filho.

Com a transcrição dos relatos, passei à etapa de organização e de apresentação destes dados, buscando uma forma que contemplasse a totalidade das falas de mães e pais, elaborando uma narrativa de cada casal para a primeira e a segunda dinâmicas, transformando os relatos das histórias narradas em textos.

A História Oral, segundo Meihy (2005), foi a estratégia encontrada que permitiu apresentar as narrativas, pois forneceu o conjunto de procedimentos que 
visam à formação de documentos destinados à análise de depoimentos. Dessa forma, adotei a História Oral como técnica para organizar e apresentar os relatos.

O autor destaca as fontes básicas que direcionam a elaboração do texto final, partindo do princípio ser inevitável a mudança que ocorre na passagem do estado de língua oral para a escrita. Ressalta que o mais importante é manter o significado do conjunto das mensagens dadas no relato, e não as palavras ditas ou pronunciadas (Meihy, 2005).

Dentre os conceitos sobre História Oral, apresentados por Meihy, destaco o que a considera: um processo sistêmico de uso de depoimentos gravados, vertidos do oral para o escrito, com o fim de promover o registro e o uso de entrevistas (Meihy, 2005, p.18).

Dessa forma, para a elaboração das narrativas recorri ao recurso da transcriação, que é a entrevista trabalhada e na fase de apresentação pública. A confecção do documento escrito foi estabelecida para as duas entrevistas realizadas com cada uma das 11 mães e sete pais, e que ocorreram por volta do $3 .^{\circ}$ e do $5 .^{\circ}$ mês de vida do lactente exposto ao HIV.

Foram 22 dinâmicas e 22 relatos resultantes das entrevistas e o processo de tratamento destas pautou-se pelas três etapas da transcriação, sendo a primeira etapa de transcrição literal dos depoimentos de oral para a escrita, e que se caracterizaram pelo resultado bruto de sons, silêncios e barulhos de fundo. As perguntas do entrevistador foram mantidas, bem como repetições, erros e palavras sem peso semântico e incompreensões.

A segunda etapa foi a textualização, que constituiu a transcrição trabalhada, quando a narrativa foi reorganizada para facilitar a compreensão do leitor, eliminando as perguntas do entrevistador, os erros gramaticais e reparadas as palavras sem peso semântico. Os símbolos utilizados para sons e ruídos também foram eliminados para tornar o texto mais claro e polido (Medina, Takahashi, 2003; Silva et al., 2006).

Ainda nesta etapa, estabeleci a lista das palavras importantes e das expressões básicas das histórias. Também foi escolhido o tom vital de cada depoimento, ou seja, a essência da narrativa, convertendo num texto mais trabalhado. O tom vital representa a frase escolhida para ser colocada na introdução da história oral, servindo como guia para a leitura da entrevista, pois reproduz uma síntese da 
moral da narrativa daquele indivíduo (Meihy, 2005).

$\mathrm{Na}$ terceira etapa, denominada transcriação, que é o produto elaborado, a entrevista foi trabalhada, está acabada e o texto recriado de maneira mais ampla. Finalizei o processo de transformação da linguagem oral em escrita, e, assim, obtive 22 narrativas correspondentes a cada dinâmica realizada.

Ao complementar essas etapas, optei por unificar as falas da mãe e do pai em cada narrativa, pois a dinâmica/entrevista foi realizada em conjunto entre ambos. Apresento-as segundo o intervalo temporal.

O passo seguinte foi analisar o conteúdo de cada narrativa individualmente, realizando inúmeras leituras para reconhecer nos dados, os aspectos da situação e da realidade estudadas, para que estes me proporcionassem familiaridade e apreensão dos significados, impulsionando a análise dos dados apurados. A mim não bastou apresentar cada relato, julguei importante analisá-los, conforme a proposta de Hammersley, Atkinson (1995), com a ordenação e categorização dos dados.

Esse processo é um dos mais complexos da pesquisa, exigindo esforços e perícia do pesquisador, pois, ao analisar os dados qualitativos depara-se com um conjunto de operações, transformações, reflexões e comprovações que necessitam ser efetuadas, com a finalidade de extrair o significado relevante dos dados em relação ao problema de investigação (Maruyama, 2003).

Ao iniciar a fase de redução dos dados, ou seja, a codificação e a categorização, que são atividades que envolvem a decisão sobre a associação de cada unidade a uma determinada classificação, destaquei as frases que chamavam a minha atenção, que atendessem aos objetivos do estudo, aquelas que apresentavam mais força, tomando essas expressões como sensibilizantes, refletindo a riqueza semântica das expressões.

Assim, foram elaborados os "conceitos sensibilizantes" realçados nos relatos, determinando a classificação das frases de cada narrativa com um código referente a um critério, com base em seu conteúdo.

Para cada frase, correspondeu um conceito sensibilizante, extraído dos depoimentos de cada mãe e/ou pai, e que poderiam, num momento posterior, constituírem-se em "conceitos definitivos". Estes são identificados como algo que se destaca como surpreendente ou intrigante ao pesquisador, com base nos relatos a 
começar do senso comum, de relatos oficiais ou de teoria anterior (Praça, 2003).

Prosseguindo, realizei um agrupamento de conceitos sensibilizantes por afinidades de conteúdo, que passaram a constituir as categorias analíticas. Ao reunir as categorias semelhantes, obtive os subtemas que representam o conjunto de conceitos sensibilizantes que compuseram uma categoria mais geral, o tema. 


\section{CARACTERIZANDO AS GESTANTES MATRICULADAS NO PROJETO TRANSMISSÃO VERTICAL ZERO}

Apresento a seguir os resultados obtidos na primeira fase do estudo, que serão apresentados em gráficos e tabelas e em números absolutos e percentuais.

O grupo de 120 gestantes inscritas no Projeto Transmissão Vertical Zero, no período de setembro de 1998 a dezembro de 2004, possui média de idade de 27,2 anos, com intervalo de confiança de $\pm 1,05$ ano, com as idades variando entre 16 e 42 anos, condizentes com achados de outros estudos sobre o tema, como de Del Bianco, Kuschnaroff, Santos (2005); Romanelli et al. (2006) e Braga, Cardoso, Segurado (2007).

Como pode ser observado na Figura 1, 11 gestantes estão na faixa etária classificada pela OMS como adolescentes, compreendido entre 10 e 19 anos (Brasil, 2005b), o que corresponde a 9,2\%; entre 20 e 30 anos se encontram 77 gestantes que correspondem a $64,2 \%$ do total das respondentes.

Quando se observa a faixa que compreende a idade de 20 a 35 anos, verifica-se a predominância das gestantes (96 mulheres - 80,0\% dos dados), o que demonstra tratar-se de adultas jovens corroborando dados encontrados em outros estudos (Del Bianco, Kuschnaroff, Santos, 2005; Romanelli et al., 2006; Braga, Cardoso, Segurado, 2007). 


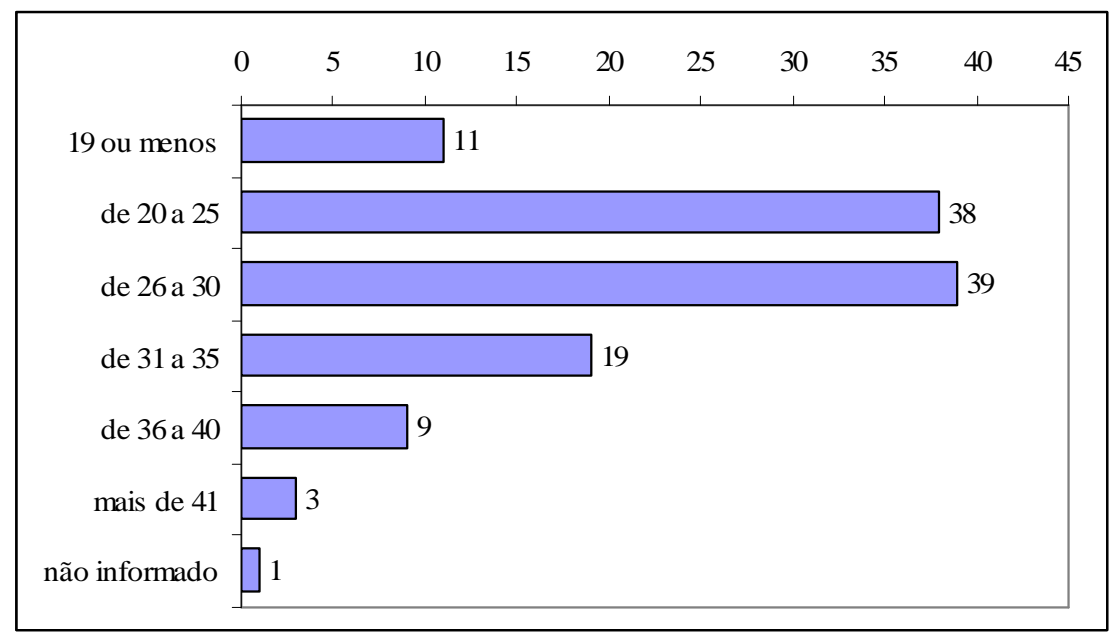

Fonte: Banco de dados COASGES.

Figura 1 - Distribuição das idades das Gestantes, matriculadas no Programa Transmissão Vertical Zero, Sorocaba, SP - 1998/2004.

No que concerne à escolaridade (Figura 2), a maioria $(68-56,7 \%)$ possui até a $8 .^{\text {a }}$ série, sendo que 10 delas $(8,3 \%)$ declararam-se analfabetas, apenas 3 informaram possuir nível superior. A maioria das mulheres com aids no Brasil tem entre quatro e sete anos de estudo, o que coincide com os achados dos estudos de Stefani, Araújo, Rocha (2004); Romanelli et al. (2006), reforçando a associação entre baixa escolaridade e incidência da doença.

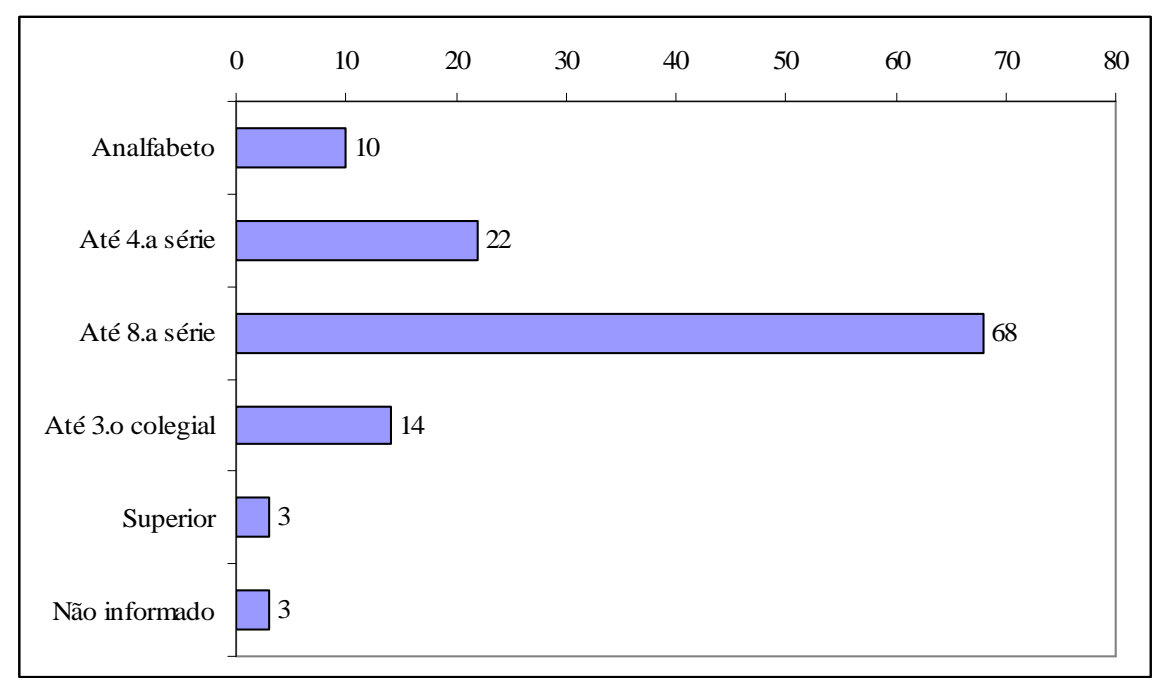

Fonte: Banco de dados COASGES.

Figura 2 - Distribuição das gestantes, por faixa de escolaridade, matriculadas no Programa Transmissão Vertical Zero, Sorocaba, SP - 1998/2004. 
A baixa escolaridade está refletida no tipo de ocupação exercida por essas gestantes (Figura 3) que, em grande parte, 74 (61,7\%) declararam-se como "do lar”, ou exercem atividades na qual o nível de escolaridade requerido é baixo, como serviços domésticos, atuação no setor de serviços e comércio (33 gestantes - 27,5\%). Merece atenção o fato de que apenas uma das gestantes informou exercer função com exigência de escolaridade de nível superior.

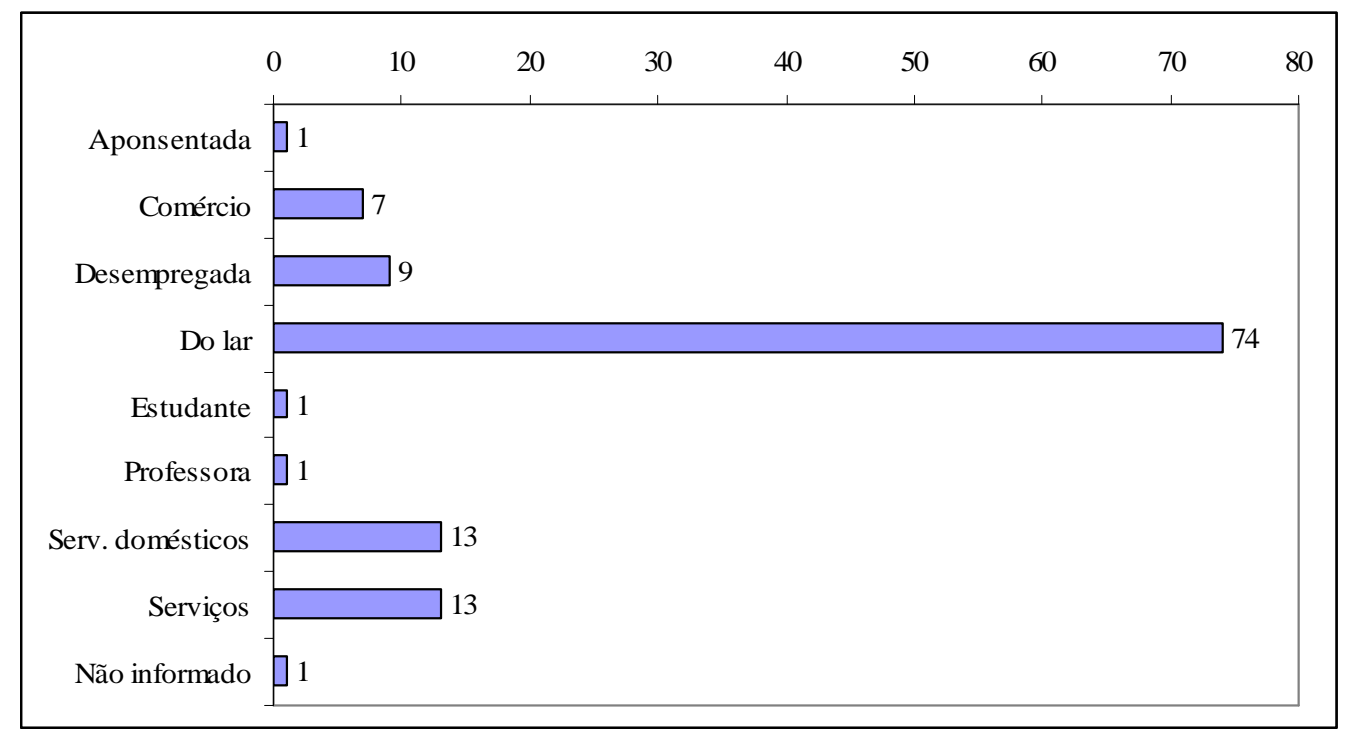

Fonte: Banco de dados COASGES.

Figura 3 - Distribuição das gestantes, por ocupação, matriculadas no Programa Transmissão Vertical Zero, Sorocaba, SP - 1998/2004.

Para a variável renda, Figura 4, 15 gestantes (12,5\%) declararam ter um salário mínimo de renda familiar e 39 (32\%) entre dois até cinco salários mínimos, enquanto 18 (15\%) não declararam a renda. É relevante o fato de que 48 gestantes (40\%) informaram renda superior a cinco salários mínimos, indicando para esse grupo uma situação econômica mais favorecida. 


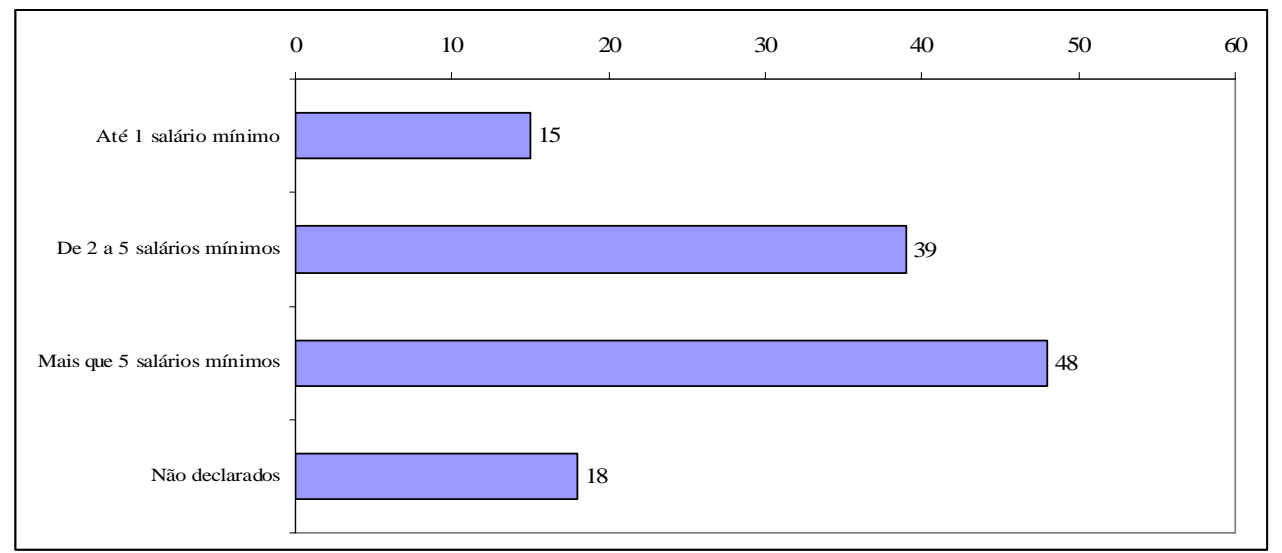

Fonte: Banco de dados COASGES.

Figura 4 - Distribuição das gestantes, por faixa de renda, matriculadas no Programa Transmissão Vertical Zero, Sorocaba, SP - 1998/2004.

Quanto ao estado civil, 96 (80\%) gestantes soropositivas informaram estar amasiadas ou casadas, indicando um predomínio para a situação de união estável, ao passo que 16 delas $(13,3 \%)$ declararam-se solteiras, 7 (5,8\%) separadas/divorciadas e apenas 1 está viúva (Figura 5).

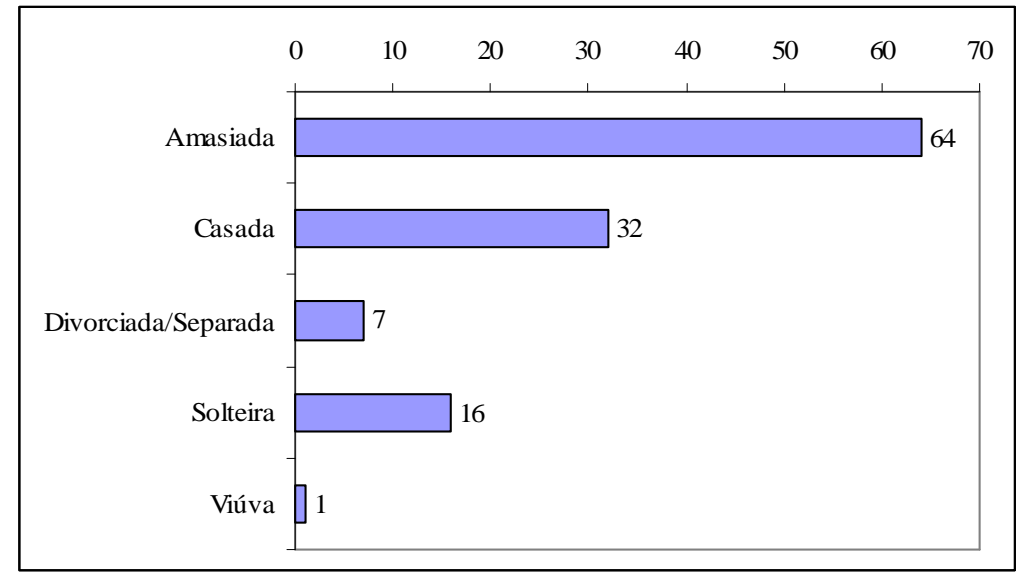

Fonte: Banco de dados COASGES.

Figura 5 - Distribuição das gestantes, matriculadas no Programa Transmissão Vertical Zero, segundo seu estado civil, Sorocaba, SP - 1998/2004.

Ainda que tenha obtido dados sobre o número de filhos vivos e mortos separadamente, não há registro das causas que levaram ao óbito.

O número médio de filhos/gestantes foi de 1,64 com intervalo de confiança de 0,28 filho, com mediana e moda igual a 1 , números que refletem que a 
taxa de fertilidade dessas mães está abaixo do padrão nacional que é de 2,1 filhos por casal (Romanelli et al., 2006). Assim, 90 gestantes (75\%) possuíam até dois filhos no momento do preenchimento da ficha pelo Projeto. Ainda que de forma reduzida, merece atenção o fato de que 14 mães declaram ter mais de quatro filhos, sendo que duas delas referiram ter seis filhos e oito filhos, conforme pode ser observado na

\section{Tabela 1.}

Tabela 1 - Número de filhos vivos por gestante da amostra, Sorocaba, SP - 1998/2004

\begin{tabular}{ccc}
\hline \multirow{2}{*}{ N. $^{\circ}$ de Filhos vivos } & \multicolumn{2}{c}{ Gestante } \\
& Absoluto & Relativo \% \\
\hline 0 & 29 & 24,2 \\
1 & 37 & 30,8 \\
2 & 24 & 20,0 \\
3 & 14 & 11,7 \\
4 & 7 & 5,8 \\
5 & 5 & 4,2 \\
6 & 1 & 0,8 \\
8 & 1 & 0,8 \\
Não informados & 2 & 1,7 \\
\hline TOTAL & 120 & 100,0 \\
\hline
\end{tabular}

Fonte: Banco de dados COASGES.

Dentre as 120 gestantes, $100(83,3 \%)$ não informaram sobre filhos mortos, mas merece atenção que, 15 mulheres $(12,5 \%)$ referiram que perderam entre um e três filhos, conforme pode ser observado na Tabela 2. Como citado anteriormente, não foi possível verificar em que circunstâncias e idade se deram essas mortes, devido à falta deste dado no questionário do Projeto.

Tabela 2 - Número de filhos mortos por gestante da amostra, Sorocaba, SP - 1998/2004

\begin{tabular}{crc}
\hline \multirow{2}{*}{ N. $^{\text {o de Filhos mortos }}$} & \multicolumn{2}{c}{ Gestante } \\
& Absoluto & Relativo \% \\
\hline 0 & 100 & 83,33 \\
1 & 8 & 6,67 \\
2 & 1 & 0,83 \\
3 & 6 & 5,00 \\
Não informados & 5 & 4,17 \\
\hline TOTAL & 120 & 100,00 \\
\hline
\end{tabular}

Fonte: Banco de dados COASGES. 
Os registros sobre a resposta para a questão "Por que decidiu fazer o teste anti-HIV?", Figura 6, mostram que as gestantes eram solicitadas a indicar três motivos. As respostas indicaram que a principal razão para a realização do teste estava relacionada com a rotina de pré-natal e/ou indicação médica que, conjuntamente, totalizaram aproximadamente $80 \%$ dos motivos apontados. O terceiro principal motivo pode ser considerado como uma combinação de relacionamento sexual com parceiros sabidamente HIV+ ou suspeitos, que totalizaram 11 indicações $(6,9 \%)$.

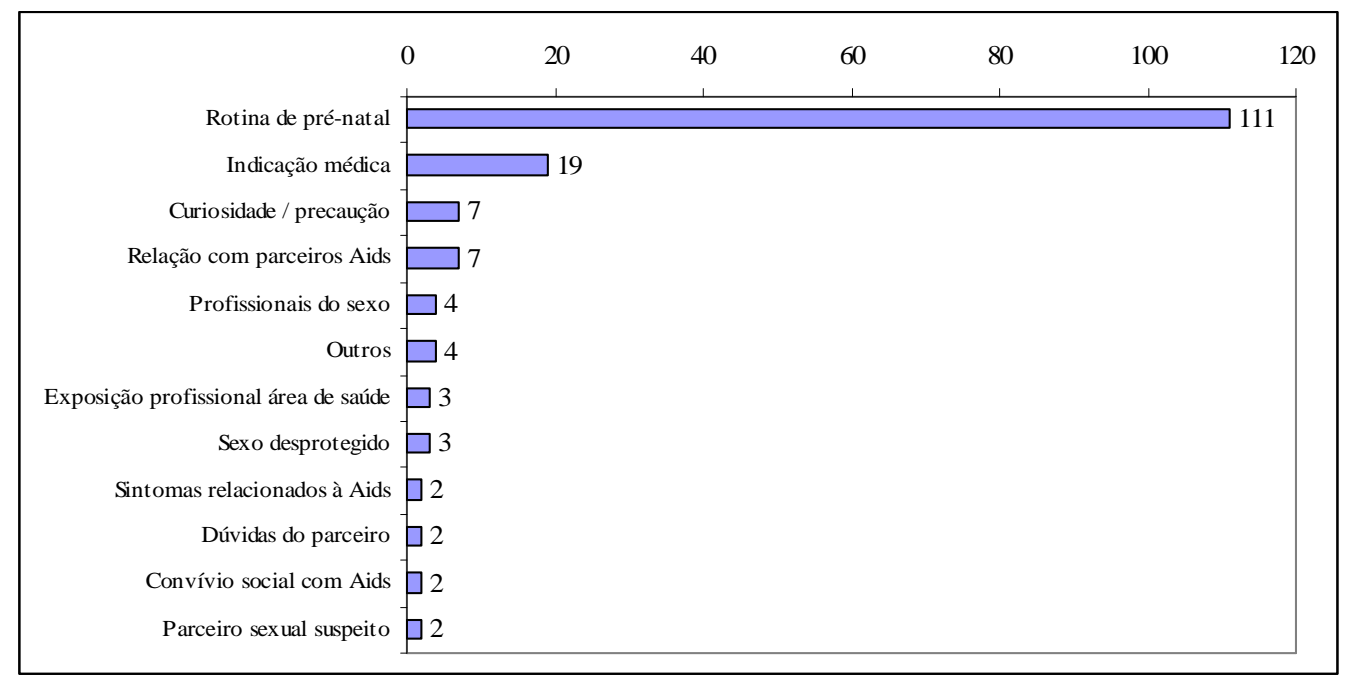

Fonte: Banco de dados COASGES.

Figura 6 - Motivos para realização do teste anti-HIV relatados pelas gestantes matriculadas no Programa Transmissão Vertical Zero, Sorocaba, SP - 1998/2004.

Em relação à pergunta "Como foi orientada para fazer o teste antiHIV no Centro de Saúde?", a ficha apresenta três quesitos com respostas dicotômicas. $\mathrm{O}$ primeiro quesito questionava se o teste foi oferecido, 86 gestantes $(71,2 \%)$ deram resposta positiva, 21(17,5\%) negativa e $13(10,8 \%)$ não responderam. O segundo quesito era referente ao conhecimento sobre a realização do teste, nesse caso, 90 gestantes (75\%) afirmaram positivamente, $16(13,3 \%)$ negativamente e 14 gestantes $(11,7 \%)$ não responderam.

Das 120 gestantes, apenas $34(28,3 \%)$ assinaram o termo de concordância com a realização do teste, 64 (53,3\%) não o assinaram e 19 (15,8\%) não responderam. É relevante ressaltar que, no início do Projeto, havia a 
recomendação de que as gestantes autorizassem por escrito a realização do exame anti-HIV, medida utilizada por cautela, no entanto, nem sempre atendida. Vale lembrar que a relação de confiança entre o profissional/serviço de saúde e a mulher é preconizada para o processo de aconselhamento, superando a formalidade (Brasil, 2007c).

Por último, à questão sobre qualquer informação sobre o teste dada à gestante, $78(65 \%)$ delas manifestaram ter sido informadas, $20(16,7 \%)$ não receberam informações e $22(18,3 \%)$ não responderam. Estes dados são superiores ao encontrado no estudo de Praça, Barrancos (2007), o qual apontou taxa de 34,2\% de puérperas soronegativas que declararam ter recebido aconselhamento sobre o teste anti-HIV e $61,5 \%$ não receberam informações. Ainda que os dados deste estudo sejam favoráveis, assinalam a necessidade de aperfeiçoamento do aconselhamento pré e pós-teste anti-HIV, como estratégia para melhoria da qualidade da assistência às gestantes, conforme Araújo, Vieira, Bucher (2006).

Para a pergunta da Ficha da Gestante Já fez o teste anti-HIV antes desta gestação? obteve-se 115 respostas, destas, 51 (44,3\%) gestantes referiram que realizaram o teste anti-HIV antes da gestação e 64 (55,7\%) não o fizeram. Dentre as 51 mulheres que se submeteram ao teste, 13 (25,5\%) informaram que o resultado foi positivo, por sua vez $37(72,6 \%)$ relataram que os resultados foram negativos e somente $1(1,9 \%)$ delas não teve resposta.

Ao serem indagadas sobre o motivo de estar se submetendo novamente à testagem, $54(45,0 \%)$ gestantes responderam tratar-se de rotina do prénatal, $49(40,8 \%)$ citaram que não fizeram o exame anteriormente, $13(10,8 \%)$ não especificaram a razão, $2(1,7 \%)$ gestantes responderam que não confiaram no exame realizado anteriormente e 1 citou nova exposição ao vírus da aids.

No que se refere à situação sorológica do parceiro, verificou-se que a maioria, 68 gestantes $(56,7 \%)$ a desconheciam; por sua vez, 29 (24,2\%) citaram que o parceiro era soropositivo, e 16 mulheres informaram que o parceiro era soronegativo (Tabela 3). 
Tabela 3 - Situação informada da condição sorológica para o HIV do parceiro, por gestantes, matriculadas no Programa Transmissão Vertical Zero, Sorocaba, SP - 1998/2004

\begin{tabular}{lrc}
\hline \multirow{2}{*}{ Situação do Parceiro } & \multicolumn{2}{c}{ Relatos } \\
& Absoluto & Relativo \% \\
\hline Positivos & 29 & 24,2 \\
Negativos & 16 & 13,3 \\
Desconhecida & 68 & 56,7 \\
Investigação & 5 & 4,2 \\
Não informados & 2 & 1,7 \\
\hline \multicolumn{1}{c}{ TOTAL } & 120 & 100,0 \\
\hline
\end{tabular}

Fonte: Banco de dados COASGES.

Ao confrontar esses resultados - motivo para realizar o teste e a situação sorológica do parceiro, na qual 29 gestantes $(24,2 \%)$ informaram ter conhecimento do estado sorológico positivo para o HIV do parceiro, posso inferir que as mulheres dificilmente realizam o teste voluntariamente, seja para evitar a confirmação do próprio diagnóstico, seja para não interferir na relação conjugal, seja por confiar na fidelidade do parceiro.

Diante da pergunta, referente ao "Uso de camisinha no último ano". 88 gestantes $(73,3 \%)$ responderam que nunca fazem uso do preservativo; uso ocasional foi apontado por 21 gestantes (17,5\%), somente uma das mulheres declarou utilizar constantemente, como demonstrado na Tabela 4:

Tabela 4 - Freqüência de uso de preservativo segundo relato das gestantes matriculadas no Programa Transmissão Vertical Zero, Sorocaba, SP - 1998/2004

\begin{tabular}{lrc}
\hline \multirow{2}{*}{ Uso de Preservativo } & \multicolumn{2}{c}{ Freqüência } \\
& Absoluta & Relativa \% \\
\hline Sempre & 1 & 0,83 \\
Quase sempre & 9 & 7,50 \\
Âs vezes & 21 & 17,50 \\
Nunca & 88 & 73,33 \\
Não informado & 1 & 0,83 \\
\hline \multicolumn{1}{c}{ TOTAL } & 120 & 100,00 \\
\hline
\end{tabular}

Fonte: Banco de dados COASGES.

O cruzamento das informações das Tabelas 3 e 4 sobre o uso do preservativo, na qual apenas 10 gestantes $(8,33 \%)$ relataram usá-lo sempre ou quase sempre. Em relação à situação sorológica do parceiro, 29 delas afirmaram ter conhecimento da soropositividade dele, revelaram que mesmo assim não adotaram a 
recomendação básica de proteção, com o uso do preservativo em todas as relações sexuais. Tal aspecto é identificado em estudo de Praça, Latorre (2003) o qual constatou reduzida adoção de medidas preventivas contra o HIV, especialmente com o parceiro fixo, aumentando o risco de infecção pela via sexual, por acreditarem que não estão sob risco para o HIV e também por confiarem na fidelidade conjugal.

Chama atenção o fato de que relação sexual desprotegida com parceiros com aids não tenha sido apontada como motivo relevante para a procura do teste anti-HIV, por estas gestantes.

No aspecto relacionado ao fator de risco, considerado desde 1980, foram apontadas como as três principais causas, as seguintes situações: relações sexuais com parceiro masculino 119 gestantes (32,5\%), parceria com parceiro promíscuo (97 mulheres - 26,5\%) e parceria sexual com usuário de hemoderivados $(33-9,02 \%)$ dispostos na Tabela 5.

Tabela 5 - Fatores de exposição ao HIV relatados pelas gestantes matriculadas no Programa Transmissão Vertical Zero, Sorocaba, SP - 1998/2004

\begin{tabular}{lcc}
\hline \multirow{2}{*}{ Fator de exposição a partir de 1980 } & \multicolumn{2}{c}{ Freqüência } \\
\cline { 2 - 3 } & Absoluta & Relativa (\%) \\
\hline Relações sexuais com parceiro masculino & 119 & 32,51 \\
Parceria sexual com parceiro promíscuo & 97 & 26,50 \\
Parceria sexual com usuário de hemoderivados & 33 & 9,02 \\
Parceria sexual com parceiro HIV+ & 27 & 7,38 \\
Parceria sexual com ex-presidiário/presidiário & 27 & 7,38 \\
Relações sexuais por dinheiro & 21 & 5,74 \\
Parceria sexual com suspeito de HIV+ & 13 & 3,55 \\
Recebeu hemoderivados & 8 & 2,19 \\
Parceria sexual com bissexual & 7 & 1,91 \\
Usuária de drogas injetáveis & 5 & 1,37 \\
Acidente perfurante & 3 & 0,82 \\
Relações sexuais com parceira feminina & 2 & 0,55 \\
Abuso sexual & 2 & 0,55 \\
Outros & 2 & 0,55 \\
\hline TOTAL & 366 & 100,00 \\
\hline
\end{tabular}

Fonte: Banco de dados COASGES.

Na Tabela 5, nota-se que a parceria sexual com parceiro HIV+ e a parceria sexual com ex-presidiário/presidiário foram citadas por 27 gestantes $(7,38 \%)$, seguida por relações sexuais por dinheiro $(21-5,74 \%)$. 
Ter recebido hemoderivados, sofrido acidentes perfurantes e outros, não totalizaram mais que 3,56\% das referências. Disso decorre que o principal fator de exposição para o grupo em estudo liga-se diretamente às práticas sexuais não seguras, conforme constatado anteriormente. A situação se agrava ao se verificar que 97 mulheres $(26,5 \%)$ citaram relacionamento sexual com parceiro promíscuo.

Ao cruzar as informações dadas pelas gestantes sobre o fator de exposição e o motivo para a realização do teste anti-HIV, depara-se com uma contradição, uma vez que 21 gestantes responderam como fator de exposição ter relações sexuais por dinheiro, no entanto, somente 4 relataram que eram profissionais do sexo, motivo que as levou a se submeterem à testagem.

Vale ressaltar que duas $(0,55 \%)$ gestantes relataram como fator de exposição ter relações sexuais com parceiro feminino.

Quanto à orientação sexual relatada pelas gestantes, a Tabela 6 mostra que 115 gestantes $(95,83 \%)$ declararam-se heterossexuais, três $(2,5 \%)$ homossexuais e uma $(0,83 \%)$ ser bissexual. Verifica-se que, na Tabela 7, o número de parceiros masculinos, no último ano, que precede seu ingresso no Projeto Transmissão Vertical Zero, não foi superior a um para 102 gestantes (85\%), dado semelhante encontrado por Praça, Latorre (2003) ao estudarem as características sociodemográficas, comportamentais e informações e práticas relacionadas à aids de puérperas internadas em maternidades filantrópicas no município de São Paulo. É interessante destacar que, à mesma tabela encontrou-se três gestantes que negaram ter tido parceiro no ano que precedeu sua entrada no Projeto.

Tabela 6 - Orientação sexual das gestantes, segundo relato das gestantes matriculadas no Programa Transmissão Vertical Zero, Sorocaba, SP - 1998/2004

\begin{tabular}{lcc}
\hline \multirow{2}{*}{ Orientação sexual } & \multicolumn{2}{c}{ Freqüência } \\
\cline { 2 - 3 } & Absoluta & Relativa (\%) \\
\hline Heterossexual & 115 & 95,83 \\
Homossexual & 3 & 2,50 \\
Bissexual & 1 & 0,83 \\
Não informado & 1 & 0,83 \\
\hline TOTAL & 120 & 100,00 \\
\hline
\end{tabular}

Fonte: Banco de dados COASGES. 
Tabela 7 - Número de parceiros relatado pelas gestantes matriculadas no Programa Transmissão Vertical Zero, Sorocaba, SP - 1998/2004.

\begin{tabular}{lcc}
\hline \multirow{2}{*}{ Número de parceiros } & \multicolumn{2}{c}{ Freqüência } \\
\cline { 2 - 3 } & Absoluta & Relativa (\%) \\
\hline Nenhum & 3 & 2,50 \\
1 & 99 & 82,50 \\
De 2 a 4 & 14 & 11,67 \\
De 5 a 10 & 1 & 0,83 \\
Mais que 10 & 2 & 1,67 \\
Não informado & 1 & 0,83 \\
\hline TOTAL & 120 & 100,00 \\
\hline Fonte: Banco de dados COASGES. & \multicolumn{2}{c}{}
\end{tabular}

Ainda que o instrumento COAS - Ficha da Gestante apresente campos para a identificação de raça e cor, estes dados não estavam disponíveis no Banco de Dados, o mesmo ocorrendo com a questão sobre Percepção de Risco das Gestantes, no entanto, Souza (2005) estudou o mesmo grupo de gestantes soropositivas e apurou que $72 \%$ delas não se viam sob risco de infecção pelo HIV, enquanto $28 \%$ declararam que se identificavam em risco de contaminação para o HIV.

Esta caracterização das gestantes soropositivas para o HIV expõe a realidade das mulheres de uma cidade de médio porte, com estrutura definida de serviços de saúde, que adota a medida recomendada pelo gestor de saúde para profilaxia da transmissão vertical do HIV, que tem como principal alvo oferecer o teste anti-HIV no pré-natal, e portanto, tal fato caracteriza uma oportunidade valiosa para o diagnóstico das mulheres, mediante a disponibilidade do teste anti-HIV em toda a rede básica de atenção à saúde.

No aspecto geral, a caracterização deste grupo de gestantes não difere da identificação encontrada em grupos de gestantes soropositivas detectadas em outros estudos, como os de Barbosa (2001); Galvão, Cerqueira, Machado (2004); Stefani, Araújo, Rocha (2004); Vasconcelos, Hamann; (2005); Neves, Gir (2006); Romanelli et al. (2006); Silva, Alvarenga, Ayres (2006).

Os dados obtidos com a caracterização das gestantes atendidas no Projeto Transmissão Vertical Zero ao longo de sua trajetória de atenção à mulher portadora do HIV/Aids foi a base para a realização do segundo momento deste estudo que buscou compreender a vivência de pais no período em que aguardam o diagnóstico do filho exposto ao HIV. 


\section{APRESENTANDO AS NARRATIVAS}

Após conhecer as gestantes atendidas no Projeto Transmissão Vertical Zero, foi possível contatar aquelas que se constituíram em colaboradoras da segunda fase deste estudo. Nesta, os dados foram coletados no primeiro e no segundo semestres de 2006.

Vale lembrar que a mãe e o pai do lactente exposto foram contatados e aceitaram participar da dinâmica proposta para coleta de dados - colagem e narrativa.

A seguir, apresento a caracterização de cada dupla mãe-pai que participou do estudo, sistematizada da seguinte forma: inicialmente dados sociodemográficos, condições de saúde e dados sobre o parto. Na seqüência são apresentadas as montagens e as narrativas resultantes de cada uma das duas dinâmicas/entrevistas, por binômio mãe-pai.

Cabe esclarecer que cada dupla mãe-pai será identificada pela palavra "binômio" precedendo o número de ordem que identifica a dupla de colaboradores, seguida pela letra "A", quando se tratou da primeira dinâmica realizada, e pela letra "B" quando se tratou da segunda dinâminca. Houve um intervalo de aproximadamente dois meses entre cada dinâmica realizada por binômio.

Foi possível verificar a condição do lactente em dezembro de 2007. Situação informada ao final da apresentação da segunda narrativa de cada dupla mãepai. 


\section{Binômio 1}

Mãe, 23 anos, ensino fundamental, católica, amasiada, está desempregada, trabalhou como babá e o último emprego foi como balconista, não se percebia em risco para o HIV, adesão ao tratamento há 2 anos. Tem três filhos, de 6 e 4 anos de idade (soronegativos) e o bebê. Soube da soropositividade no $4 .^{\circ}$ mês de gestação do $3^{\circ}$ filho, infectada pelo parceiro, pai do bebê, que era presidiário. O pai do bebê, de 24 anos, ensino fundamental incompleto, ajudante de pedreiro, soube da soropositividade durante a gestação do bebê, único filho.

Parto Cesárea, atenção ao protocolo 076, não realizou laqueadura tubária. Na segunda dinâmica a mãe apresentava-se só; foi abandonada pelo parceiro, situação que a obrigou a trabalhar, montando brinquedos no domicílio, dada à proximidade de uma a fábrica próxima a sua casa.

Assim como para os demais binômios, a dinâmica foi realizada após a coleta de material para a $1^{\text {a }}$ contagem de carga viral do bebê, aos 3 meses de vida, porém antes da obtenção do resultado do exame.

\section{Montagem 1A}

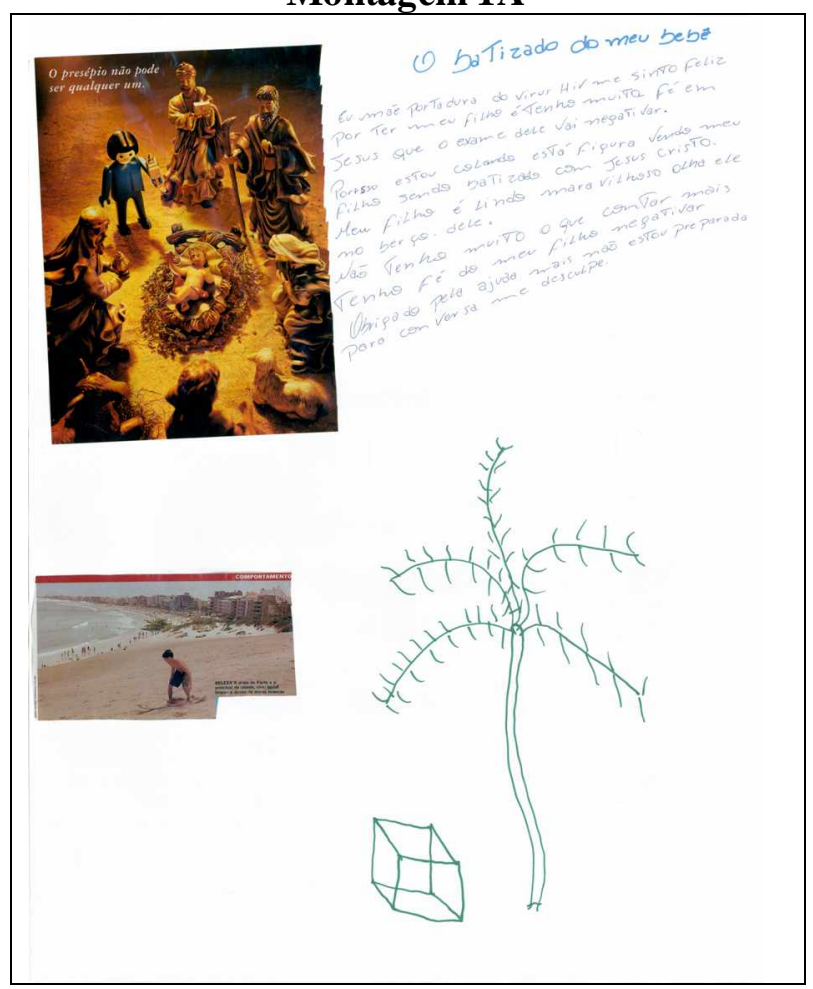

\section{Narrativa 1A}

Tenho muita fé em Jesus, que o exame dele vai ser negativado.

$\mathrm{Eu}$, mãe portadora do vírus HIV, me sinto feliz porque imagino meu filho sendo batizado como Jesus Cristo. Tenho muita fé em Jesus, que o exame dele vai ser negativado.

O batizado será no primeiro domingo de março, o pessoal da Igreja Católica está nos acompanhando, ajudando e incentivando bastante. Estou numa fé, numa certeza... Tanto é que eu fiz uma promessa pra Nossa Senhora Aparecida me ajudar, desde quando descobri. Em junho, na festa de Aparecidinha, vou levá-lo vestido de anjo, da catedral até a 
igreja de Aparecidinha... nessa luta que estou compartilhando... eu e ele (parceiro).

Eu converso mais, o jeito dele (companheiro) é fechado, ele quer mais trabalhar, não ficar em casa. Eu fico mais com o bebê, convivo mais com as crianças, ele tem pouca paciência.

Qual a sua incentivação? (dirigindo-se ao parceiro) Imagine o K na praia... Vamos supor, ele está com 10 anos na praia, você sentado e brincando na areia ou de esqueitista... Você imagina o quê?

Ah! Eu não estou nessa não... Não sei fazer isso (referindo-se à atividade proposta, desenhou o coqueiro e o dado).

Você sentado debaixo do coqueiro, pegando e cortando coco pra ele, ensinando-o a pegar e cortar, tudo isso...

(Opai aponta para o desenho) É um dado. Eu não sei falar, verdade, eu não sei.

(A mãe dirigindo-se ao parceiro) Seu pai nunca brincou com você? (Resposta) Ah? Meu pai?!?

(Novamente questionando o parceiro): Você não imagina brincar com o K.?

(Pai respondendo à mãe) Não sei nada, Ah! Deixa pra lá.

Igualmente como os demais, o Binômio 1 apresentou o segundo relato sobre o significado da segunda montagem realizada. Observa-se que, precedendo cada narrativa, há o tom vital que caracteriza a dupla mãe-pai naquele momento de vida do lactente.

A dinâmica para realização da atividade da Montagem 1B, assim como para os demais binômios, ocorreu aproximadamente no $5^{\circ}$ mês de vida do lactente, após conhecimento do resultado do $1^{\mathrm{o}}$ exame e após coleta de material para a $2^{\text {a }}$ contagem de carga viral, porém ainda sem divulgação de seu resultado. 


\section{Montagem 1B}

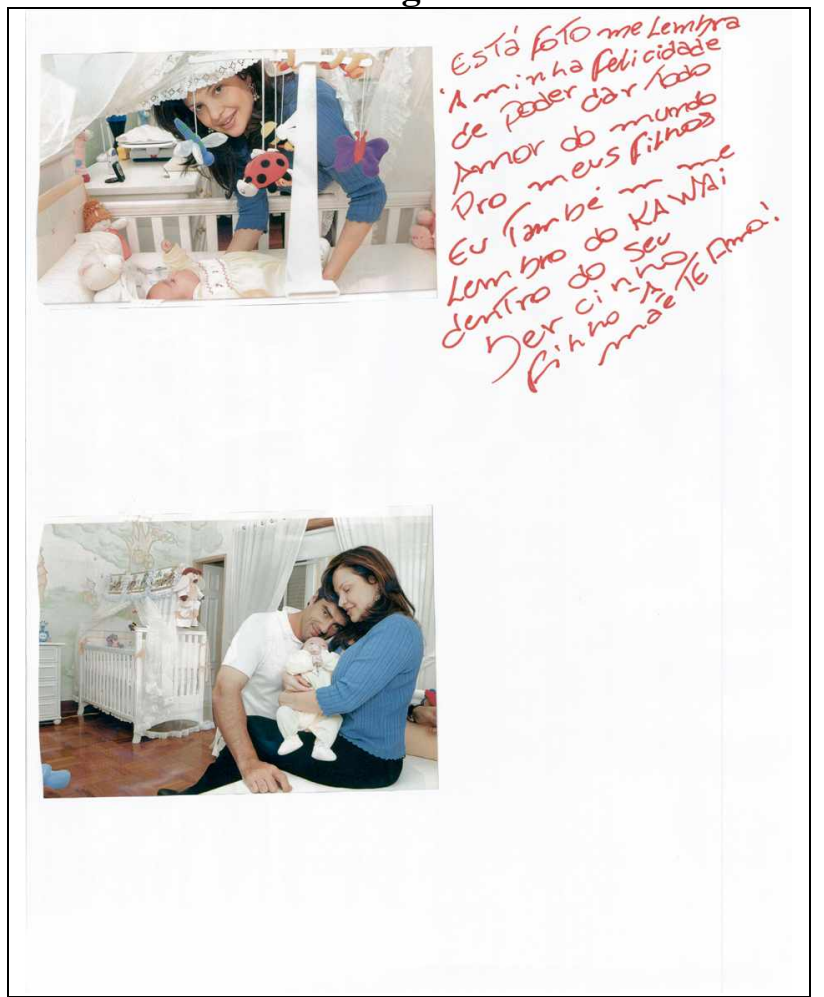

Narrativa 1B

Agora rezar pra Deus e continuar a luta.

O primeiro resultado deu negativo, o segundo eu não sei. Hoje ele vai passar com a médica, mas eu estou com uma expectativa que vai dar tudo certo. Se Deus quiser, ele não tem nada. Está sendo difícil, mas fazer o quê? A gente que é mãe tem que dar a vida pelos filhos... Ele está esperto, esses dias ficou doentinho, estava com febre alta, febre eu tenho medo, eu fiquei com medo, levei pro hospital na Santa Casa, era uma gripe forte, graças a Deus.

A minha garganta está tão ruim, peguei um quintal pra carpir, levei três dias. Já passei pelo médico, é falta de ar. Todo

sábado vou pra igreja católica. Meus filhos estão bem, já fizeram o exame e não deu nada, graças a Deus... Se Deus quiser ele também não. O pai dele não o viu mais, não deixo, agora estou só... pra comprar remédio e fralda, um monte de coisa para o moleque. A partir do momento que ele começar a me ajudar, ele poderá ver o menino, ele tem direito, enquanto eu sustento sozinha, não. Não vou deixar ver. Hora de deixar, ele não pensou. Por que agora ele tem que ver? Fazer coração mole?

Eu pus uma Nossa Senhora perto do berço, ele (bebê) olha pra Santinha, acho que ela conversa com ele e ele ri, dá cada gargalhada alta... Deus é grande.

Quando cheguei do hospital, a nossa felicidade era estarmos juntos. Arrumei tudo. A gente poder estar com o nosso filho, tem várias mães que o filho tem esse negócio, muitas vezes, não vai pra frente, morre antes de nascer e eu, graças a Deus, tive a oportunidade de dar a luz. Eu tenho muito carinho por ele e quero dar todo o amor do mundo pra ele, né, preto? Essa outra (gravura) é quando ele (parceiro) ainda estava conosco e a nossa felicidade é saber que ele não tem nada. Agora rezar pra Deus e continuar a luta.

Dezembro de 2007: o lactente com 2 anos, está em acompanhamento na clínica, em virtude do adoecimento da mãe, impossibilitando de comparecer às consultas. 


\section{Binômio 2}

Mãe 34 anos, ensino fundamental, evangélica, amasiada, acreditava ser de risco para o HIV, três filhos, dois com o primeiro marido (11 e 9 anos), é viúva há 9 anos (marido morreu assassinado por arma de fogo), adesão ao tratamento há 7 anos. O parceiro é soronegativo, 37 anos, ensino médio, católico, desempregado, único filho.

Parto cesárea, atenção ao protocolo 076 e com laqueadura tubária. O pai participou das duas entrevistas.

Montagem 2A

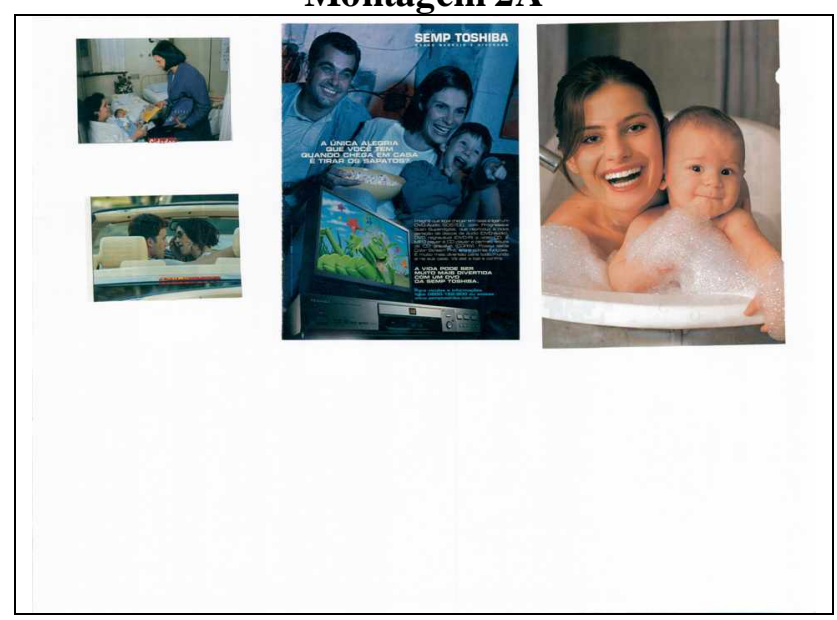

\section{Narrativa 2A}

Mas é coisa que eu não gosto nem de pensar.

Pra mim ele não tem... Na minha cabeça a gente sabe que vai ter que ficar um ano e meio tirando sangue pra fazer os exames. Não entendo. Ele vai fazer quantos exames? Vai ter que fazer o mesmo? Vai diminuir? Vai subir? Por enquanto eu não sei como funciona isso. Eu a acompanho (esposa), o

exame sobe, depois desce, zerou, mas, o dele não tenho a mínima idéia. Hoje, se o exame estiver aí, às vezes demora, é uma coisa que poderia ser mais rápida, não ficou pronto por causa do laboratório, aí vai mais um mês pra saber... Ficar com aquilo na cabeça será que subiu? Desceu? A mesma coisa hoje, se não tiver pronto, a gente vai esperar mais um mês, se chegou, como que é? Como que está?

No meu dia-a-dia, não vou dizer que eu não penso, entra por um lado sai por outro, ouve aqui e deixa sair por aqui. Eu penso, mas já sai rapidinho da cabeça, mas a gente sente, porque a gente vê o desenvolvimento e a agilidade dele com dois meses, a força que está nas pernas. Ele é muito esperto.

Então, a gente sempre pede a Deus pra que realmente Ele ponha a mão, não só pra ele (filho), mas para todas as crianças, desde que a mãe se cuide como ela se cuidou, não só por ele, ela já se cuidava. Então, não adianta depois falar: meu filho pegou e tal, porque às vezes, com esse tipo de problema você tem que levar uma vida mais saudável possível. Se você fuma, tem que parar de fumar, se a mulher costuma beber, ela tem que parar de beber, para que se engravidar não aconteça nada. Tem criança que pega, mas também não impede dele ter, por mais que ela se cuidou. Mas é coisa que eu não gosto nem de pensar.

$\mathrm{Eu}$, pelo menos, lembro mais na hora de dar o xaropinho, o remedinho, que é dia sim, dia não, segunda, quarta e sexta. Se não fosse isso... 
Eu não sinto nada, pra mim não tem nada. Eu me sinto muito bem, muito bem, mesmo assim, tenho lá coisas normais, que qualquer mulher tem. Gripe, essas coisas.

Um dá força para o outro, por mais que a gente tenha problemas, a gente tem apoio um com o outro. Porque só a minha família sabe, minha mãe, meu pai, meus irmãos; a família dele não sabe, então, apoio mesmo é nosso. A minha mãe mora longe, não tem como se abrir com ela, conversar, quando ela vem em casa, a gente nem toca nesse assunto.

(Apontando a montagem): A mãe tomando banho junto com o filho numa banheira... Felicidade, alegria... Não importa o problema que tenha.

\section{Montagem 2B}

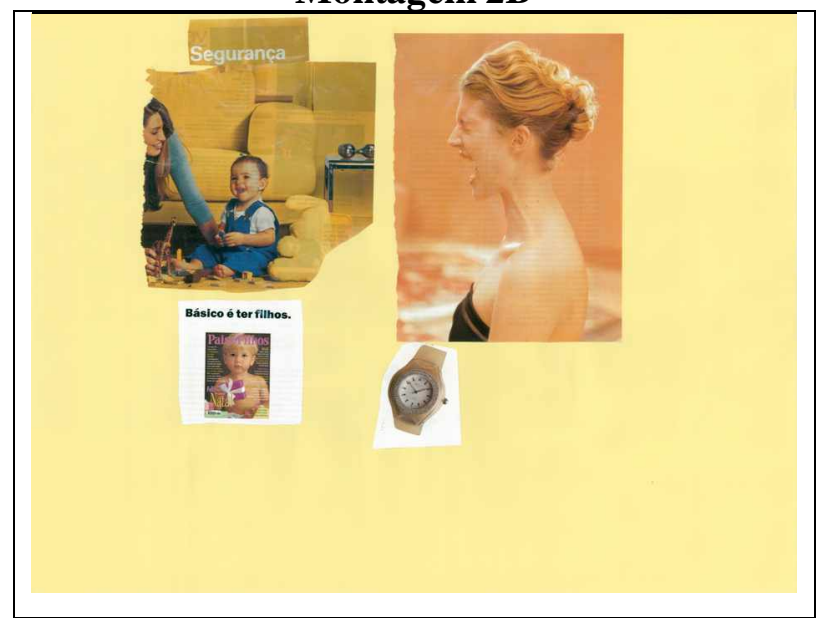

Narrativa 2B

Nesse momento não sou eu, não importa eu, é o futuro deles, a felicidade deles, é eles... Porque se eu fosse sozinha, acho que não estaria mais aqui, porque a vida é muito difícil.

Independente da aparência da criança é uma alegria, ela está se sentindo segura. Não tem uma imagem de um homem, geralmente o homem fica longe, ou trabalha, ou tem alguma coisa para fazer.

Quem está junto é a mãe, a criança sente mais segurança estando com a mãe do que com o pai. Quando a mãe morre e o pai fica, a dificuldade é tão grande pra ele cuidar, criar, essas coisas... Do que o contrário, o pai morrer e a mãe ficar, a segurança total vem da mãe. O pai tem as suas obrigações e deveres, mas só que a segurança faz parte da mãe, se a mãe não se sentir bem, a criança não vai ficar bem. O básico é ter filhos, quando você casa ou que não case ou alguma coisa assim, tá aqui pra perante Deus, um homem, uma mulher gerar filhos, não adianta só gerar um filho, tem que dar segurança, alegria, atenção, até o resto da vida, até um dos dois, quando Deus quiser levar. Seguir o ritmo normal da vida, praticamente pelo resto da vida, a mãe pode morrer com 70/80 anos, e o filho vai continuar... Mas, só Deus para fazer esperar que vá bem, que mesmo que não dê, ele vai ter a segurança, educação, vai ter tudo. Ele merece, todas as crianças merecem, mas isso dependendo da mãe, se a mãe não se tratou, não se cuidou...

Então, infelizmente, talvez possa acontecer alguma coisa pra mulher, independente de ser esse problema, a mulher fuma/bebe, alguma conseqüência vai trazer para o filho, então, não é só essa justificativa dessa doença, é tudo. A mãe fica grávida, o pai pode continuar fazendo o que ele estava fazendo, teoricamente, não está prejudicando a criança, mas, a mãe não, se ela ficou grávida tem que parar com tudo, observar...

São nove meses de tensão, de preocupação, altera o corpo, a mulher fica achando que não está mais bonita, essas coisas. Mas, se ela não se sentir bem por estar gerando um filho, depois, quando nascer, 
ela também não vai dar... atenção que ele merece. Eu vejo vários casos assim.

A gravura revela uma segurança, uma criança feliz, alegre, independente do que ela tenha, né? Ela está brincando com a mãe, um monte de bichinhos, sorrindo. O essencial não é só ter, tem muita coisa, educação, os cuidados, planejar futuro, a gente sempre planeja uma coisa, e o filho sempre faz outra. A minha gravura não é só o bebê, não é o bebê, é tudo... Eu estou a ponto de ai, jogar tudo pro alto, subir, gritar, espernear, muito mais... Eu tô muito cansada, cansada mesmo, a ponto... Mas, não faço pelos filhos, não faço nada de errado pelos filhos, pelos filhos e a outra (gravura), é que estou funcionando 24 horas por diiiiiaaaaaaa, sem descanso, sem nada, nada, nada...

É funcionar a minha cabeça, o meu corpo, é só funcionando, pensando, agindo, falando, falando. Às vezes, não dá pra falar, tem que ficar quieta. Então, a cabeça funciona 24 horas por dia, dia e noite, tem problemas com as crianças, com os filhos e com a mãe dele (avó paterna).

Ele tem pai... Os outros dois não têm pai, se eu não tiver bem, como é que eu vou fazer? Não tem lugar pra ir, não tem... Vai ter que mandar um pra um lugar e o outro pra outro. Caso eu chegar a tombar mesmo, a cabeça explodir, eu penso nisso; eu quero os meus filhos junto comigo, comigo eles estão bem. Então, ficar com os outros? Separado, não fica complicado. Nesse momento não sou eu, não importa eu, é o futuro deles, a felicidade são eles... Porque se eu fosse sozinha, acho que não estaria mais aqui, porque a vida é muito difícil, muito, muito...

Agora nós estamos com um pouquinho de dificuldade financeira, mas, não é isso, é mais... O problema conjugal que não dá certo, às vezes, meus filhos também não dão certo, ele quer que faça uma coisa, quer que faça outra.

Nós não estamos conseguindo no momento viver juntos, por diversas coisas, o gênio de cada um. Mas, o que eu sempre insisto, é que a gente não pode pensar só em nós. Ah, vamos tentar só nós dois, mas, nós estamos esquecendo que existem três que dependem da nossa felicidade, junto ou não pra crescer, ser alguém no mundo. Então, esse negócio de casal, tem que ficar por último. Primeiro vêm os filhos, situação financeira, depois o casal. Por enquanto, não está acontecendo de dar certo, a gente não pode deixar que uma palavra, que afinal, todo mundo vai sentir, não só os dois.

Dezembro de 2007: o lactente com 1 ano e 10 meses, com diagnóstico negativo para o HIV.

\section{Binômio 3}

Mãe, tem 33 anos, ensino fundamental, católica, autonôma, três filhas (17 anos, 11 anos - soropositiva, e o bebê), acreditava ser de risco para o HIV, pois o 1. ${ }^{\circ}$ marido era usuário de drogas e faleceu há 10 anos de aids, adesão ao tratamento há 10 anos, é comunicativa e tranqüila. O parceiro é soronegativo, 29 anos, ensino 
fundamental, sem religião, amasiado, desempregado, tem sete filhos com várias parceiras, demonstrou carinho com a filha.

Parto cesárea, atenção ao protocolo 076, fez laqueadura tubária. O pai participou das duas entrevistas.

Montagem 3A

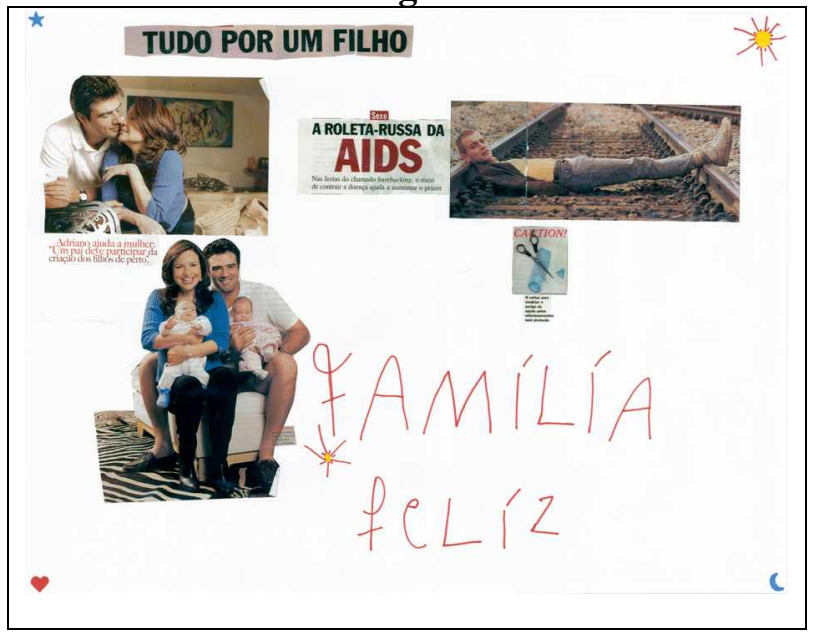

Narrativa 3 A

Tudo isso é o preconceito... Pessoas que sabem que você tem, não querem tocar nas coisas que você tocou.

A gente faz tudo por um filho, acorda de madrugada pra dar o remédio certinho, né? Se a gente não cuida deles, quem vai cuidar? Lógico, a gente faz tudo por um filho... E o resultado do exame será feliz, porque eu sei, eu tenho certeza que a minha filha não vai ter isso. Porque eu tomei o remédio certinho, estou dando o remédio certinho...Família Feliz, é uma família, você, eu, A e a AJ. É importante porque, se a gente não tiver um apoio familiar, a gente fica louca.

Eu jamais teria coragem de me matar... Acho que as pessoas que têm esse problema deveriam aceitar, levar a vida como ela é, sem colocar na cabeça, sem suicídio, porque as pessoas são normais, não é por causa de uma doença, que vai tentar se matar, se suicidar, se envenenar... Eu falo pra ela, não tem só essa doença, tem câncer, tem várias doenças mais bravas, não colocar isso muito na cabeça, que é uma coisa meio psicológica, não é verdade?

Quando eu a conheci, já faz 7 anos, ela mentiu pra mim desse problema, porque ela tinha medo que eu a evitasse ou não quisesse ficar com ela, mas logicamente que eu fiquei bravo por ter mentido. Agora que ouvi da boca dos outros, as pessoas falavam, sabia que fulano... Sabia que a fulana tem isso, pegou isso do marido, e eu não acreditava, mulher bonita, saudável, como quê? Quem vê cara, não vê coração.

Nossa! Como que vou chegar e falar para os meus pais. Minha irmã já sabia, ouvia comentários dos outros, falando que ela é soropositiva. Aí, minha irmã perguntou: você transa com ela sem preservativo? Não. Não fizemos nada disso ainda, minha irmã falava toma cuidado...

Tinha que chegar na minha mãe, né? Meu pai é alcoólatra, o que ele falar ou deixar de falar, né? Conversei com minha mãe, ela é contra. Teve muito preconceito...

"Largar de uma pessoa pra ficar com aquela bichada, aidética, você não tem juízo, não tem cérebro." A gente não é goiaba. Só que agora minha sogra prefere eu que a outra.

Ela falava que eu não a amava, e perguntava: por que não tenta fazer um filho em mim? Tinha vontade de ter um filho, sonhava com um filho, eu também queria ter um filho com ela... Ela eu quis 
ter. Ela falava pra mim: Quando você falava que queria ter um filho comigo, eu pegava preservativo seu e furava com a agulha. Tudo bem, que isso é uma coisa, maravilhosa, só que podia também prejudicar...

Quer saber de uma coisa? Eu tô nem aí, morando com ela me sinto bem. Gosto dela, acho que nós vamos viver, só se ela não quiser ou Deus levá-la de mim. Nem vou usar mais preservativo. A moça do COAS ficou brava comigo, disse que eu era louco. Faço exames desde 2001. Quando ela ficou grávida fiz novamente, deu negativo também. Eu falei pra ela, você não tem nada, é uma coisa da sua cabeça, é uma coisa psicológica, da sua mente, se você colocar você fica doente. Por que atrai, né?

Estou feliz em estar com ela, acostumado ficar junto. Eu estou desempregado, sempre dou uma assistência pra ela.

Depois que eu a conheci, as coisas mudaram, as pessoas mudam, né? Se não fosse por ela, eu podia estar preso/morto, entendeu? Por bagunça, má companhia. Eu gosto dela porque pega no meu pé.

Ele era muito rueiro, bebia, era mulherengo, mas, agora que eu tive ela (bebê), ele fica mais em casa.

O resultado do exame será feliz... porque eu sei, eu tenho certeza que a minha filha não vai ter isso... porque eu tomei o remédio certinho, tô dando o remédio certinho...

Tudo isso é o preconceito... Pessoas que sabem que você tem, não querem tocar nas coisas que você tocou. Eu já vi pessoas assim, a gente senta num lugar, e não querem sentar no seu lugar, eu vi isso no posto de saúde, é ela sentar e as pessoas que sabem que ela tem, irem sentar lá na frente, sendo que tem lugar ali. Eu falo pra ela, olha o preconceito ali. A coisa que mata mais na pessoa, é isso aí, sabia? Antes de conhecer ela, eu não conhecia nada desse negócio entendeu? Não entendia nada, aí tinha medo, verdade, tinha medo.

Montagem 3B

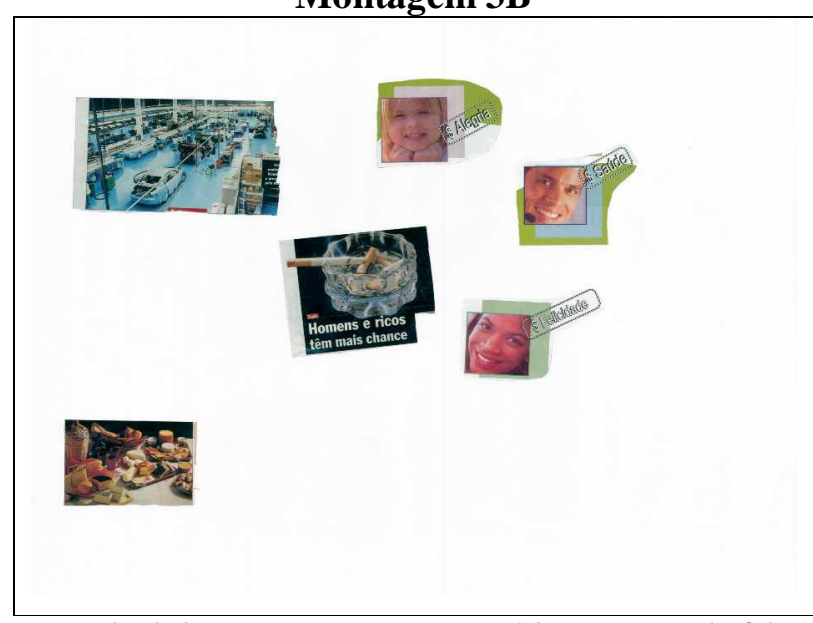

\section{Narrativa 3B}

A gente está numa fase em casa, que brigamos sempre, não sei por que está assim. Não sei se é por causa de estar desempregado ou porque tenho esse vício de fumar e de beber.

Hoje, eu estou alegre por ter conseguido (colher sangue) e se Deus quiser vai dar tudo certo e depois a gente só quer felicidade, pro filho da gente, né?

Espero que eu consiga um emprego,

entendeu? Que eu pare com meus vícios e que nada falte pra minha filha, poder dar tudo pra ela. A gente está numa fase em casa, que brigamos sempre, não sei por que está assim. Não sei se é por causa de estar desempregado ou por que tenho esse vício de fumar e de beber, entendeu? Então, às vezes, isso está atrapalhando entre eu e ela e está prejudicando minha filha também... Não sei por que ela tá ligeiramente estressada comigo... A gente anda discutindo demais. É tirar o sangue da menina... Ela 
fala pra mim que está sendo um inferno... Não sei por que né? É isso aí, eu espero que corra tudo bem, que a gente sempre esteja junto pra criar minha filha perto. Tudo poder dar pra ela, não só pra ela.

Ele (companheiro) não é muito de conversar, eu já comento mais com a minha sobrinha, né? Porque ele tem que mudar um pouco esse jeito dele, sabe? Ele é muito fechado, ele não é de conversar comigo, ao invés dele chegar e falar assim, né? Então, eu acho que eu me preocupo mais que ele.

Que nem ela falou que eu me expresso quando bebo, ela fala que eu às vezes até ofendo ela. Quando eu não bebo sou um cara quieto, se bebeu já estragou. "Você fala as coisas, acaba me ofendendo, entendeu?"

Agora você falou pra mim que você ia mudar, né? Eu vi que você não está mudando, sei lá. Seja o que Deus quiser.

Espero que eu arrume um emprego. Dar tudo pra ela é isso que eu espero, né? Que corra tudo bem. Que nem hoje, ela (bebê) tirou sangue, esperar esse resultado. Se Deus quiser tudo vai dar certo. Eu tenho bastante fé em Deus.

Dezembro de 2007: o lactente com 1 ano e 10 meses em acompanhamento na clínica.

\section{Binômio 4}

Mãe, 21 anos, ensino médio incompleto, católica, amasiada, segurada pelo INSS, não se percebia em risco para o HIV, primeiro filho de ambos, adesão ao tratamento há 1 ano. Pai, 31 anos, ensino fundamental, católico, amasiado, soropositivo, segurado pelo INSS acompanhou as consultas, quieto, mas prestativo.

Parto cesárea, atenção ao protocolo 076 e com laqueadura tubária. O pai participou das duas entrevistas. 
Colagem 4A

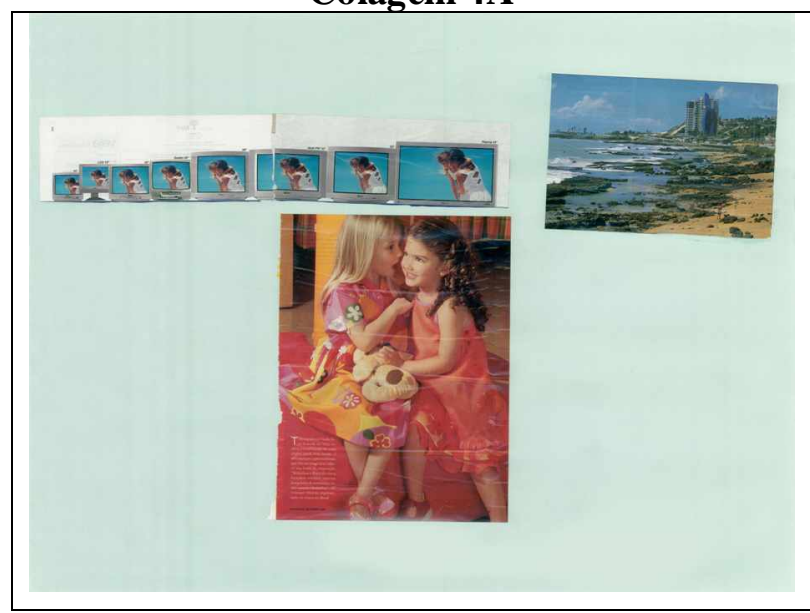

Narrativa 4A

Nunca pensei negativo e quero que ela cresça bem. Se ela tivero HIV ou não, e se negativar ou não, do mesmo jeito, nós vamos continuar amando ela.

Todo dia eu acordo e penso... "eu desejo pra ela que ela cresça e cresça bem. Que essa doença não esteja com ela. Será que ela vai crescer todas as etapas da vida dela? Aí, isso fica na minha cabeça, faz

eu pensar que ela cresça bem desde o começo. Todo dia que eu acordo, eu desejo isso pra ela, que dê tudo certo o resultado. Que ela vá crescendo, crescendo, e que a gente possa também crescer junto com ela".

Essa gravura aqui é pelos dias felizes que nós estamos passando com ela. Nós fomos pra praia e levei ela na beirinha do mar só pra sentir como é. Só faltou ela querer entrar no mar. Eu sempre penso em ver ela grande, brincando. Penso positivo, nunca pensei negativo e quero que ela cresça bem. Se ela tiver o HIV ou não, e se negativar ou não, do mesmo jeito, nós vamos continuar amando ela. Não tem muito que falar... É duro... É esperar e torcer. Se tiver, a gente vai ficar com ela até o fim, até o fim... Se Deus quiser ela não tem nada, não tem nada, será firme e forte. A gente sempre conversa nessa mesma tese. Como vai ser o resultado dela? A gente leva do jeito que dá.

\section{Montagem 4B}

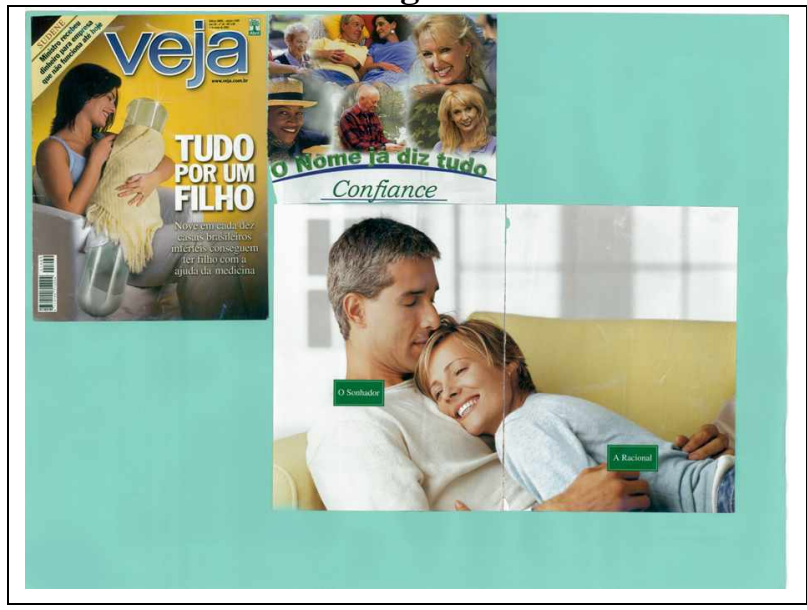

Narrativa 4B

A gente está unido no propósito de ajudar ela até o final, vai dar certo, se Deus quiser.

A gente faz tudo por um filho. Imagina no caso de estar esperando o resultado do exame laboratorial dela, por mais que desse positivo, a gente também espera um pouco da Medicina, que hoje está bem avançada. Hoje em dia muitas coisas, muitas doenças que antes a gente sabe que de uma hora para outra, se for pela vontade de Deus, um dia vai ter cura.

A gente faz tudo pra vontade dela, a gente vê que tudo para nós hoje é ela, gira em torno dela, porque ela é a única pessoa que precisa de nós, até poder caminhar sozinha. A gente vive sempre pensando no 
resultado do exame. Será negativo ou positivo? Nós sempre estaremos juntos. A gente não desgruda dela principalmente pra sair, não deixa com ninguém. Fazemos tudo o que o médico manda, mas nunca colocamos coisa negativa na cabeça. O que vai dar isso? É depressão. A gente vai pensando sempre positivo. Eu estou feliz.

Sobre a gravura, ela mostra confiança, que vai dar certo, que vai ser tudo legal pra ela. Apesar das brigas que a gente tem em casa, todo casal tem, mas nós estamos "unidão" pra ajudar ela. Não tem muito que falar, né? Felicidade... Puxa, estou alegre mesmo (risos), contente. A gente tem confiança que o próximo exame vai dar a mesma coisa, se Deus quiser, porque ela (bebê) merece. A confiança que eu tenho é que tudo vai dar certo... que ela (bebê) vai ficar desse jeito, se Deus quiser, velhinha, velhinha. Somos um casal legal, temos briguinha, mas a gente está unido no propósito de ajudar ela até o final, vai dar certo, se Deus quiser.

Dezembro de 2007: o lactente com 1 ano e 10 meses em acompanhamento na clínica.

\section{Binômio 5}

Mãe, 31 anos, ensino fundamental, católica, amasiada, do lar, três filhos (10 anos - outro pai, 5 anos e o bebê), não se percebia em risco para o HIV, soube do diagnóstico durante a gravidez do 2..$^{\circ}$ filho (há 6 anos) e iniciou o tratamento. Pai, 38 anos, ensino fundamental, católico, amasiado, é soropositivo há 6 anos, tem dois filhos, adesão ao tratamento há 6 anos, trabalho temporário como mecânico.

Parto cesárea, protocolo 076, fez laqueadura tubária. O pai participou apenas da primeira entrevista. 
Montagem 5A

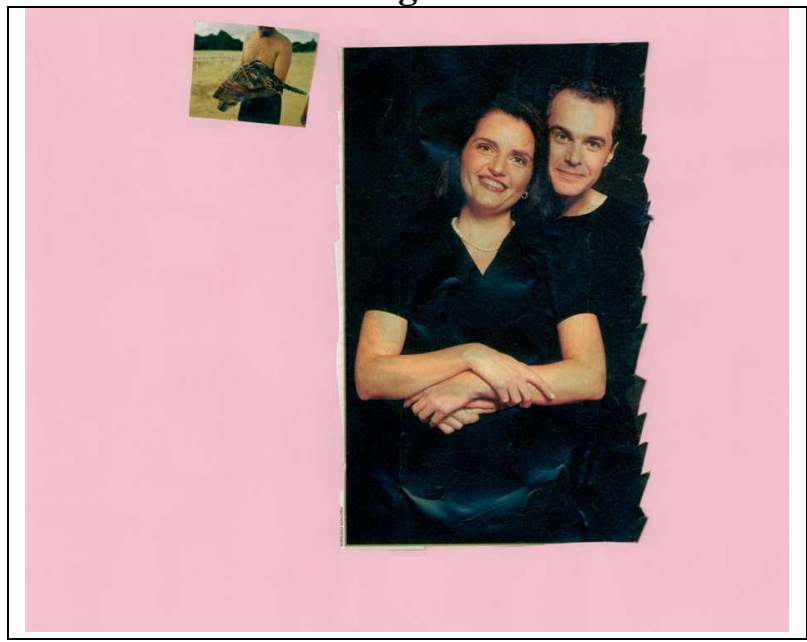

Narrativa 5A

Penso, eu fico na maior

expectativa, vai negativar, vai negativar.

Eu fiz esse casal porque a gente vive um casal normal, um casal perfeito, sossegado, a gente não pensa no HIV. Pra mim tem a ver muita coisa, porque a gente vive assim, a gente tem mais filhos saudáveis, e tem ele (bebê) que não tem ainda... saúde. Eu penso, eu fico na maior expectativa, vai negativar, vai

negativar. Agora ele (bebê) nem fez o exame até hoje de carga viral, não fez ainda, ele vai fazer, entendeu? A gente fica naquela expectativa, ai meu Deus. Agora estava conversando com uma mulher lá fora, ela falou: "meu filho negativou com 7 meses, já me dá mais empolgação pra ir em frente..."

Essa montagem aí significa que a tartaruguinha está presa, ela está esperando ter a liberdade, poder ser solta, ter liberdade. Assim é meu filho... Esperando ele fazer os exames e ter resultado positivo, pra ele poder ficar livre disso aí. Esperando a liberdade, para poder seguir em frente, senão, não fica uma coisa livre, fica uma coisa meia presa.

Montagem 5B

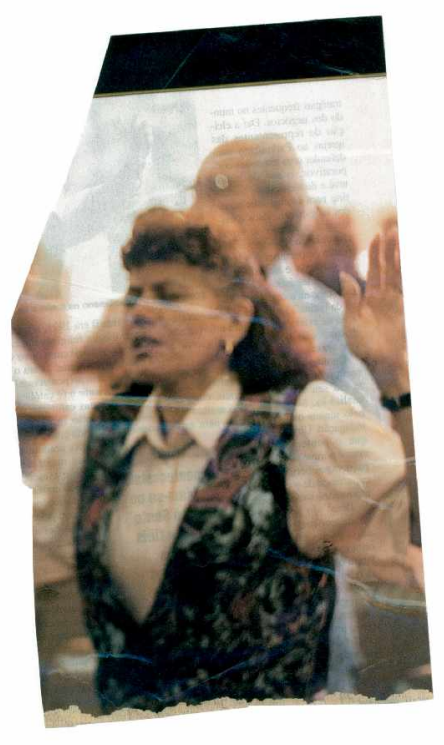

Narrativa 5B

Tenho fé que vai negativar sim, isso aí simboliza uma fé, a minha fé, se não fosse a minha fé, a fé da minha família, ele não tinha... A fé é assim, a gente se reúne e reza, a gente pede a Deus.

É um símbolo de fé, eu acredito muito em Deus, que ele (bebê) vai negativar logo. Ele passou muito mal, ficou 27 dias na Santa Casa, eu fico naquela expectativa - meu Deus... Será que é a doença?

Ai, meu Deus, por que ele está na UTI? Eles me confortaram muito. Falavam: Não mãe, tá vendo, aquela criança não tem, aquela criança não tem e tem o mesmo problema, está com pneumonia 
avançada. Eu fiquei naquela expectativa, tomara Deus que negative logo... negativando é tudo mais fácil, fica gripado, mas vai curar e essa doença já não deixa eu ficar pensando isso...

Meu Deus do céu, será que é perigoso ficar doente? A gente não tem aquela confiança total, mas agora não, eu aprendi que Deus existe, porque o médico desenganou ele. Foi Deus mesmo que curou ele... Graças a Deus ele está se recuperando, tá bonitinho, engordou bastante. É isso que eu penso, só Deus mesmo, porque simboliza Deus, porque ela está pedindo a Deus, eu tenho fé que ele vai negativar logo. No hospital falaram pra mim: têm uns que negativam e outros não... Mas vai negativar porque eu fiz tudo certo, tomei todos os remédios, acompanhei desde o primeiro mês da gravidez até o final. Agora vamos ver, tenho fé em Deus que negativa sim. Essa imagem é a minha fé. A minha primeira filha não teve esse problema, sempre foi saudável, amamentei e tudo, já no segundo filho, o I, ele vai fazer 6 anos, com 1 ano e 2 meses negativou, esse moleque dá muito problema pra mim, dá muita dor de cabeça, é asmático, mas negativou graças a Deus. Eu tenho fé que vai negativar sim.

Simboliza uma fé, a minha fé, se não fosse a minha fé, a fé da minha família, ele não tinha... A fé é assim, a gente se reúne e reza, a gente pede a Deus. Nossa fé é assim, a minha filha sabe que eu tenho, que sou portadora, meu filho sabe, só meu menino, que não entende muito as coisas, mas percebe. Mãe: “Hoje a gente vai na clínica?” Daí a gente fala que vai na Policlínica e todo mundo vai na clínica. Quando eu separei do meu primeiro marido, ele chegou e falou pra ela (filha), que tinha uns 6 anos, "Sua mãe vai morrer, ela está com aids". Essa menina ficou traumatizada, hoje ela já sabe que é diferente, a gente discute em casa, ninguém vê o que eu tenho, tudo diferente, por isso que eu vivo bem.

Ele (o pai do bebê) mudou bastante sabe? A gente mudou, já é outro cuidado: banho tem que ser bem na hora do sol quente, aumenta mais o cuidado da gente, mas muita fé também ele tem, chorou muito quando o médico chegou e falou: "só Deus mesmo para curá-lo". A gente ficou muito unido sabe? Mas agora vamos ver, porque ele não mora mais comigo, ele me dá apoio, eu tô tranqüila, a gente pensa assim, ai, meu Deus é uma gripinha? A pediatra falou que não pode pensar assim, ele está bem. Graças a Deus melhorou sim.

Dezembro de 2007: o lactente com 1 ano e 10 meses em acompanhamento na clínica.

\section{Binômio 6}

Mãe, 23 anos, ensino médio, católica, amasiada, desempregada, soropositiva há 3 anos, não se percebia em risco para o HIV, tem uma filha de 6 anos, o 1. ${ }^{\circ}$ marido faleceu com Aids, adesão ao tratamento há 2 anos. Pai, 23 anos, ensino médio, católico, amasiado, soronegativo, trabalha em uma granja, um filho, não 
acompanhou nenhuma consulta e não quis participar das dinâmicas.

Parto cesárea, atenção ao protocolo 076 e não realizou laqueadura tubária.

Montagem 6A

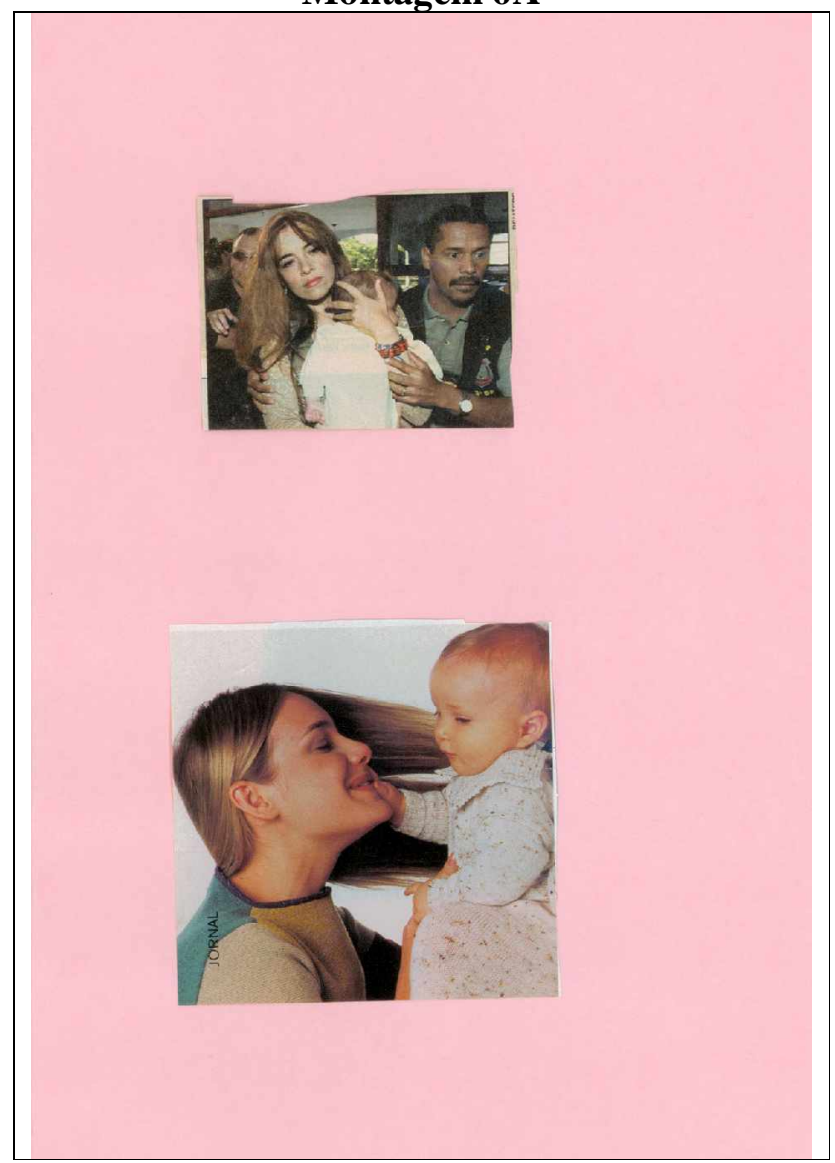

\section{Narrativa 6A}

O que está sendo mais

complicado é esta parte.

Esconder, sempre esconder... É complicado até pra gente falar sobre isso, é difícil conversar sobre isso. Eu peço todo dia pra que ela não venha ter isso, que negative...

A gente sente mais cuidado, proteger do mundo, bem dizer do preconceito das pessoas. Fica com mais cuidado com relação ao bebê, porque quer proteger. É difícil, Deus queira que não, mas vai que aconteça e dê positivo, a gente tem que estar preparado pra tudo. Eu tenho medo porque minha sogra não sabe, vou ao posto próximo de casa com ela (bebê), quando eu venho aqui na clínica eu não posso dizer a ela porque não sabe de nada. Inclusive quando eu não podia amamentar, o peito estava cheio,

ela vivia perguntando: "Por que você não dá de mamar? Tem leite."

Não foi por mim. Ele (parceiro) não quis dizer, por mim eu já tinha dito. É difícil, ele está escondendo... A família dele não sabe, nem os irmãos, a minha todos sabem. Se fosse por mim, já tinha dito, mas ele não quer, é um direito que ele tem. A família é dele, ele não quer contar. Eu achei melhor... Mas é difícil. Você tem que sair e esconder o remédio, é duro, entendeu? Ela (bebê) não toma, mas eu tomo. Já tomou o AZT, ela vai pegar esse medicamento agora (Bactrim), a avó do bebê achava que aquele remédio era xarope... Porque ela não sabe ler, então fica mais fácil pra esconder dela, mas, os irmãos sabem ler e aí tem que ficar escondendo. Vira e mexe estão dentro de casa convivendo com a gente, ela é a única neta. É complicado, o que está sendo mais complicado é esta parte. Esconder, sempre esconder... É complicado até pra gente falar sobre isso, é difícil conversar sobre isso. Eu peço todo dia pra que ela não venha ter isso, que negative... Fiz tudo certinho, até agora tudo deu certo, agora é só aguardar o resultado. 
Montagem 6B

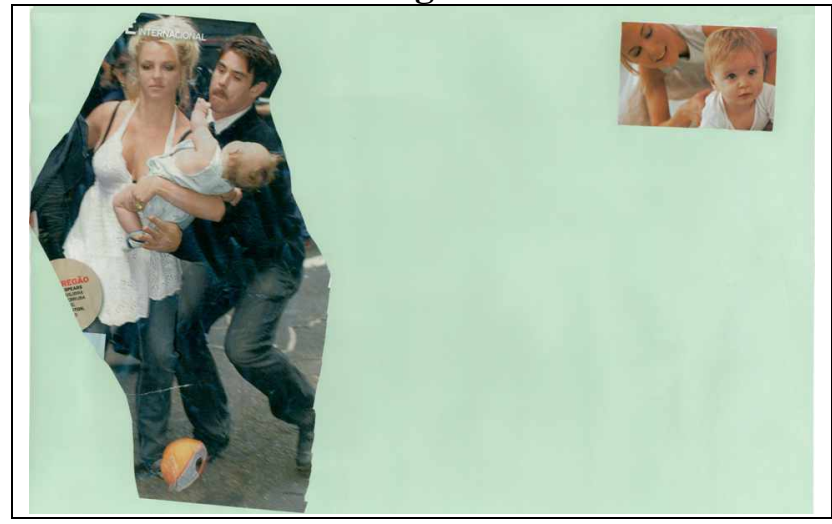

Narrativa 6B

A família se uniu, antes ele nem ligava quando ela estava pra rua, deixava, agora não... ele se preocupa mais, uniu a nossa família.

Essa gravura aqui é o desespero que a gente fica, quando a criança adoece, a gente tem mais cuidado, pensa que por causa do problema, qualquer coisinha

vai prejudicar, entendeu? Se der uma aguinha gelada, se der banho frio, se pegar um resfriado. O cuidado é dobrado, porque a gente acha que pega com facilidade, se desespera, ela está gripada, a gente fica preocupada, achando que vai, sei lá... vai dar uma pneumonia, uma bronquite, porque o organismo é pequenininho, frágil, é fraco. Por causa do problema, você fica com medo, enquanto não tiver o resultado em mãos, não tem como a gente não ficar preocupada...

O cuidado vai ser sempre em dobro, como se fosse uma criança especial, tem que estar mais atento. Esses dias ela ficou toda empipocada, com alergia de pernilongo, ficou com caroção, porque alergia pode causar qualquer coisa, febre... Ele (parceiro) fica em cima mais dela (bebê) do que da outra maiorzinha. Ela fica com ciúmes. Quando a gente vê que ela está com ciúmes, a gente agrada, porque ela não entende, não sabe e me fala: "Por que ela vai ao médico todo mês, e eu não?" Eu tive que marcar uma consulta pra maiorzinha na clínica, mesmo não estando doente, a dela é lá e não aqui, ela quer vir aqui, porque a irmã vem. Aí, eu marquei com a psicóloga da clínica, elas conversaram e ela ficou toda feliz, porque a consulta era só dela e não da irmãzinha.

E aqui (gravura) eu vejo ela grande, saudável e não tem nada, sem nada... sem o problema, tudo certo, é o que eu espero que aconteça.

Eu tenho um pouco de medo se der positivo, porque na família dele (companheiro) ninguém sabe. Eu tenho medo de rejeitarem, entendeu? Porque eles não sabem, eles a tratam normal, eu penso o seguinte: se descobrir um dia? Pode ser que não... quero que dê negativo. E quando souber que eu tenho? Como saber qual a reação deles? Querer rejeitar por ela ter uma mãe assim... e ela poder ter nascido assim, entendeu? Tudo isso é o medo que eu tenho.

A gente não conversa sobre isso com a família dele, só converso com ele. Ele fala que ninguém tem nada a ver com nossa vida, acha que a mãe não tem que intrometer nem ninguém da família. O que importa é entre mim e ele, porque eu converso com ele e peço pra ele falar antes que chegue no ouvido dela, ele optou por não contar a ninguém, só entre nós e vamos levando. Ela (sogra) não tem que palpitar, intrometer na nossa vida, o que importa é o que ele pensa e sente, ele fala pra mim.

A gente se uniu mais. A nossa família se uniu mais, eu, ele, a menininha, a minha filha que é só minha. Ele se aproximou dela, ficou mais amoroso, tem mais cuidado com a maior, a chegada dela (bebê) foi uma benção, foi uma benção.

Ele nem se preocupa, nem pergunta o resultado do exame, pra ele tanto faz, se ela tiver ou não, ele vai amar do mesmo jeito. Só fica preocupado quando ela fica doente, pergunta se estou dando o remédio 
certinho, na hora certa. É um monte de remédio, tem que tomar o Bactrim, o sulfato ferroso, o polivitamínico, agora a médica passou mais um xarope, porque ela tá meio gripada... Então, ele chega e já pergunta todo dia, se dei o remédio certinho, se dei água, se ela tomou banho, se preocupa. A mais velha também, às vezes, ele chega, ela está brincando no vizinho, pergunta: "não tá na hora dela vir?" A família se uniu, antes ele nem ligava quando ela estava pra rua, deixava, agora não... ele se preocupa mais, uniu a nossa família.

Dezembro de 2007: o lactente com 1 ano e 7 meses em tratamento com ARV.

\section{Binômio 7}

Mãe, 33 anos, ensino fundamental, católica, casada, do lar, é soropositiva há 9 anos, não se percebia em risco para o HIV, tem quatro filhos (8 anos, 5 anos, 4 anos e o bebê) todos do mesmo pai. Adesão ao tratamento há 5 anos, uso irregular dos anti-retrovirais. Pai, 33 anos, ensino médio, militar, evangélico, sabe da soropositividade há 10 anos, adesão ao tratamento há 9 anos, acompanhou todas as consultas e as duas entrevistas.

Parto cesárea, atenção ao protocolo 076 e não realizou laqueadura tubária.

\section{Montagem 7A}

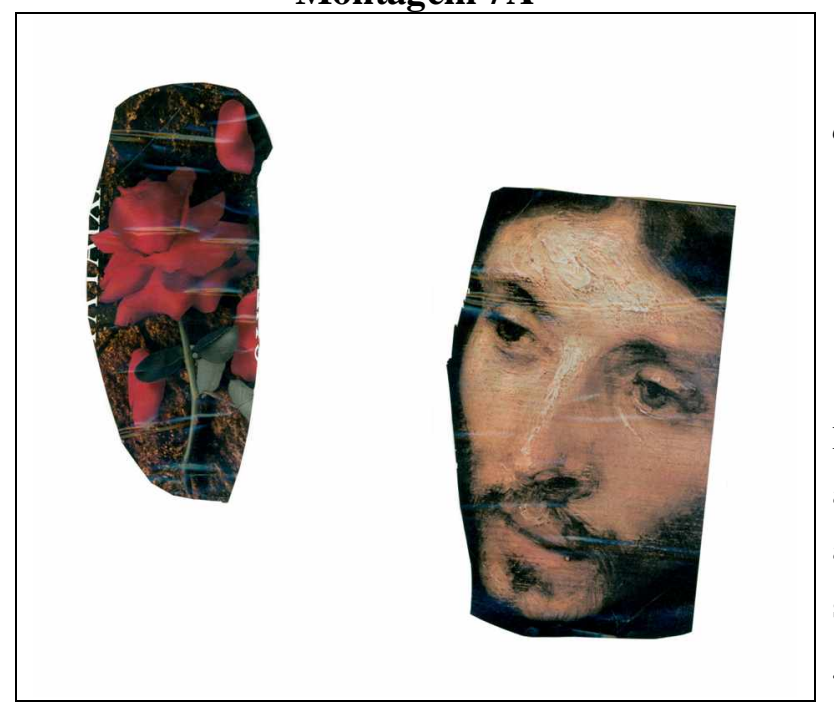

\section{Narrativa 7A}

Eu tenho três filhos e crio da mesma forma e ficaram livres desse mal. Da mesma forma, creio que um dia vou fazer o exame e ter a minha cura também, minha família vai estar liberta desse mal. Minha vida gira em torno disso, Jesus, entendeu?.

Eu escolhi a rosa, acho que a gente fica ansiosa enquanto não sai o resultado, ansiosa... Tenho medo de dar positivo, sei lá, tenho medo... Porque sempre a gente falha quando a gente toma 
remédio, deu uma falhada... Ai, eu não sei. Desde quando eu me converti em 99, creio que já no primeiro exame, se for da vontade de Deus, nós sejamos curados. Jesus veio ao mundo e morreu na cruz em três dias. Ele levou nossas dores, transgressões, pecados e também nossas doenças na cruz do calvário.

Então, creio que é da vontade de Deus que todos nós que tememos Jesus, sejamos curados. Pode vir no 1. ${ }^{\circ}$ exame, como eu não tenho essa ignorância, pode vir por causa dos anticorpos, eu sei, eu tenho instrução pra isso, a pediatra falou assim:

- Mas com certeza virá. Com certeza não, se for da vontade de Deus eu creio que não virá eu tenho fé. Basicamente todos os dias eu vivo em torno da esperança.

A fé é esperança, porque esperar algo que você não consegue ver é fé. A fé é você esperar algo que não existe, que ainda vai existir. Você estando firmado em Jesus você está seguro... Jesus significa isso, realmente segurança. Eu tenho três filhos e crio da mesma forma e ficaram livres desse mal. Da mesma forma, creio que um dia vou fazer o exame e ter a minha cura também, minha família vai estar liberta desse mal.

Minha vida gira em torno disso, Jesus, entendeu? O principal da minha vida é Jesus, e os outros problemas da vida, os percalços a gente passa, né?

Olhando a rosa, mostra que a vida é uma beleza, só que tem espinhos, a vida tem os espinhos, mas lá em cima, após passar pelos espinhos, tem um código, tem uma coisa bonita. Jesus mesmo falou "o mundo te dá opções e eu venci o mundo". Se Jesus, o meu Mestre, venceu o mundo, Ele também nos deu oportunidade para que nós vencêssemos.

Nós vamos passar por tudo isso e vamos vencer. Nosso dia-a-dia é normal como qualquer outro casal: é briga, é discussão, a gente se gosta, se ama, daqui a pouco, a gente está discutindo. Falar a verdade, eu nem me toco desse problema, às vezes, minha preocupação maior é a criação dos meus filhos, são contas pra pagar, são meus compromissos que tenho que resolver.

O HIV está bem distante dos meus problemas, pra mim não é problema, isso daí já está resolvido, então, a nossa qualidade de vida é boa, graças a Deus.

Passando aquelas dificuldadezinhas que até agradeço, tem um plano aí que dá o leite, mesmo sendo militar, o meu salário é um pouquinho melhor do que muita gente. No momento, minha realidade não é tão boa assim, então está ajudando bastante. Creio aqui em Sorocaba... é uma cidade que dá apoio total. 
Montagem 7B

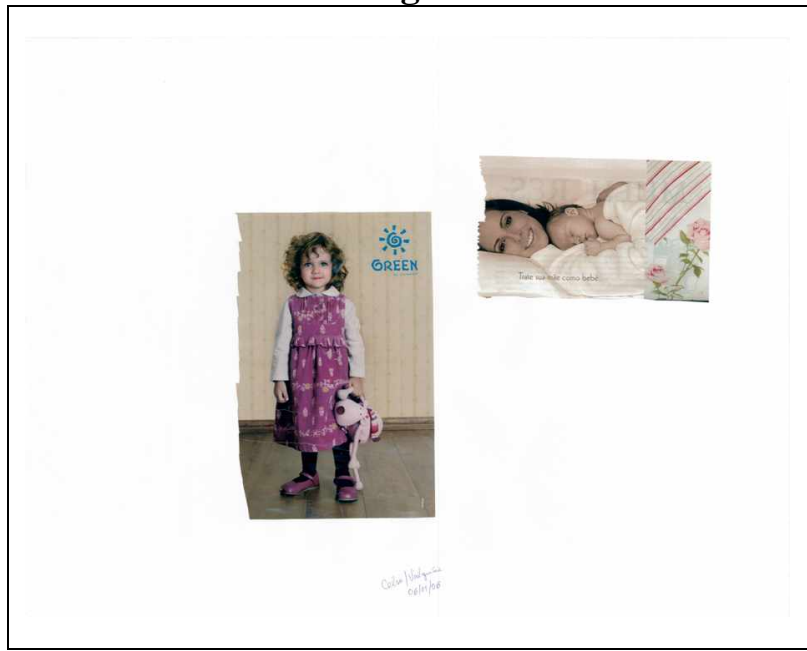

Narrativa 7B

\section{A fé que eu tenho em Deus creio} que ela não tem nada.

A gravura mostra uma foto de menina que deve ter entre 3 e 4 anos. É a expectativa que tenho de ver a minha filha saudável como qualquer outra criança. A esperança que eu tenho e certeza que ela crescerá como os irmãos, ser uma criança normal, saudável. Quase não fica doente, eu creio que em breve uma notícia boa de que ela não tem nada

e poderemos tocar a vida normal. Então, a foto dessa criança... é para mostrar a esperança que tenho de ver minha filha bem, com saúde, daqui 3 ou 4 anos, com esse tamanho aí, brincando, é isso que eu quero hoje.

O resultado dela é pra mim... assim, é normal, porque eu já passei por três, então... acho que está normal. O primeiro eu não sabia que tinha, amamentei 2 anos e mesmo assim não tem nada... Dois anos e meio esperando.

Ela fez tratamento e só amamentou o primeiro filho. Ele fez um exame só, que já era grande. Fez o acompanhamento desde que ele nasceu e ficou comprovado que ele não tinha nada.

Meu dia-a-dia é normal. A gente faz tudo que tem que fazer, quando vai ver se esquece que tem que vir aqui (clínica).

Porque, tipo assim, a gente não fica com aquela paranóia na cabeça, aquela coisa de tem que ir, não, a gente tá levando uma vida normal, até porque não adianta ficar se martirizando, perdendo noite de sono por isso.

Eu só fico assim, quando ela fica resfriada, daí eu já começo ficar nervosa, e quando ela chora demais eu fico nervosa, acho que ela tem alguma coisa, dor, infecção. Ah. Eu fico nervosa e com medo de acontecer alguma coisa com ela, eu sou assim com todos, quando um tem alguma coisa, eu começo a chorar.

A gente vive desde o nascimento até chegar adulto com esperança, tem certeza que vai alcançar, por isso que a fé é esperança também, tenho a certeza que ela (filha) tá curada, porque ela é uma criança normal, ainda que não seja, eu sei que isso pode ser só anticorpos, daqui 1 ano, entendeu?

Pode isso se desfazer, reverter, mas eu creio em primeiro lugar que com a ajuda de Deus e com a Medicina de hoje está bem mais avançada, com tratamento melhor, eu creio que melhore. Eu tô tranqüilo, a fé que tenho em Deus, creio que ela (bebê) não tem nada. E o meu pensamento agora é saber como criá-la, botar no caminho certo, na escola, o que vai fazer daqui pra frente. Minha preocupação é com meus filhos, encaminhá-los para que sejam cidadãos formados, bem formados, bem direcionados, bem-educados, não sejam como muitos que tem hoje em dia: desviados, cheios de problemas. Minha preocupação maior é essa, quanto à doença não tenho preocupação nenhuma... 
Dezembro de 2007: o lactente com 1 ano e 6 meses em acompanhamento na clínica.

\section{Binômio 8}

Mãe, 31 anos, ensino fundamental, evangélica, do lar, amasiada, 6 filhos do mesmo pai, soube da soropositividade há 2 anos e 6 meses, não se percebia em risco para o HIV. Pai, 36 anos, analfabeto, católico, catador de materiais para reciclagem, amasiado, soropositivo (usuário de drogas), teve várias intercorrências (Hepatite B e C, Tuberculose) e internações. Não acompanhou nenhuma consulta com o pediatra, nem as entrevistas.

Parto cesárea, atenção ao protocolo 076 e com laqueadura tubária.

Montagem 8A

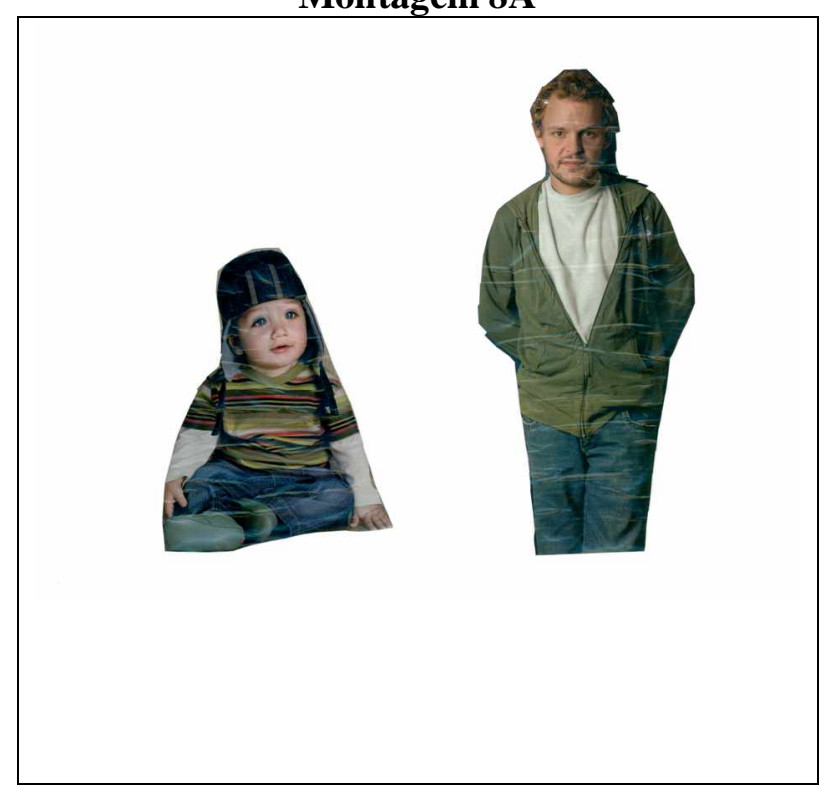

\section{Narrativa 8A}

Eu fiz o tratamento certo pra não passar nada pra ela. Eu tenho Deus no coração e tenho fé, a primeira coisa eu penso em Deus, e sei que eu posso ter, mas meus filhos não.

Vou esperar mais ou menos 1 ano e 6 meses, como aconteceu com meu outro filho. A imagem do rapaz representa um pensamento... Será que vai dar certo? Será que vai dar positivo ou negativo? Então, está em pensamento, entendeu? E a imagem do bebê, depois que eu fico sabendo, numa hora eu penso assim, que

vai dar tudo certo, que a minha filha não tem nada, ela está bem de saúde, não tem nada, o sangue dela está limpo.

Eu penso que pode acontecer alguma coisa, eu estava grávida do M quando soube, se eu tenho, o pai dele tem, o menino vai gerar com a doença... Fiquei ansiosa pra chegar a hora da doutora F falar:

"Está tudo bem, o menino não tem nada". É que nem com a J, eu penso... será que vai correr tudo bem ou será que escapou alguma coisa? Eu fiz o tratamento certo pra não passar nada pra ela. Eu tenho Deus no coração e tenho fé, a primeira coisa eu penso em Deus, e sei que eu posso ter, mas meus 
filhos, não, entendeu? Então, tudo pode acontecer. Eu fico pensando é... ansiosa pra saber o que vai dar.

A gravura do bebê representa que a minha filha $\mathrm{J}$ vai ter um resultado bom, eu fico pensando que ela está bem, eu tô vendo que ela não está demonstrando nada, nenhum sinal da doença. É duro saber que... foi duro saber que eu estava com esse problema, e saber que eu fiquei grávida e... o medo, medo de passar na criança, medo de passar nela. E... eu tenho muita fé que ela não tem.

\section{Montagem 8B}

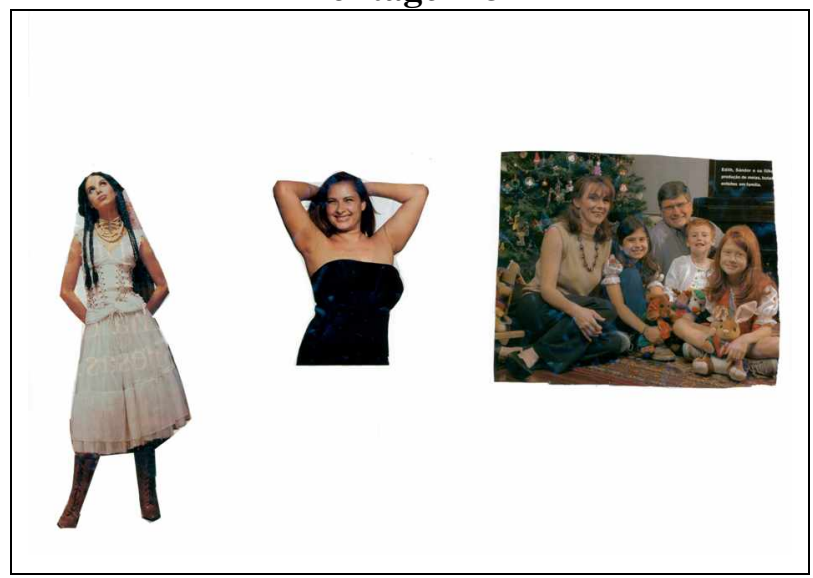

Narrativa 8B

Deus cura, se a gente tiver fé

Pra Deus nada é impossível... Desde o começo quando descobri que era soropositiva, eu não queria aceitar, porque isso foi um choque... Eu tenho seis filhos, eu falo:

"Meu Deus, vai chegar uma hora que vou morrer, e meus filhos vão ficar pequenos...” Eu sei que pra Deus nada é

impossível, Deus cura, se a gente tiver fé, né? Nesta gravura é o pensamento... na expectativa... se virá positivo/negativo, pensando mesmo o que vai dar. Esperando ansiosa a chegada do exame, a gente passa pelo médico e fica sabendo que o exame dela dá negativo, se no $1 .^{\circ}$ deu negativo, o $2{ }^{\circ}$ e o $3{ }^{\circ}$ também vão dar. Na outra, é de uma família feliz, a gente pode saber que tem, o pai do neném tem, mas os filhos não têm, entendeu? Pra mim é uma grande felicidade... Felicidade...

Eu queria que a minha vida fosse assim... porque a minha vida não é desse jeito, meu marido já colocou na cabeça sobre a doença, então, tem hora que a gente está unido, alguma coisa acontece ele. fica nervoso. Que nem eu tô vendo essa imagem tão bonita, está o pai, a mãe e os filhos, tudo em paz. Eu gostaria que a minha... a minha família fosse assim, sabe? Entre eu, meu marido e meus filhos.

Enquanto estou aguardando, eu faço de tudo pra que dê certo, eu oro, peço pra Deus que dê tudo certo e que o exame... dê negativo, a gente cuida o máximo que pode, entendeu? Tem medo, mesmo a gente que tem o HIV, encostar, não é fácil de pegar, mas mesmo assim, eu converso com meu marido sobre as crianças não terem, a gente evita muitas coisas, encostar nas crianças, ferimento, porque eu morro de medo de passar qualquer tipo de doença pras crianças, a gente evita o máximo que pode... O que a gente dá é muito amor e carinho, o que eles precisam.

Porque eles sabem, os mais velhos sabem que a gente tem o problema, só que não gostam de comentar, mas as pessoas jogam na cara dos meus filhos, sua mãe é aidética/seu pai é aidético, corta o coração, eles contam pra gente e dói no fundo do coração. Eles perguntam:

- "Pai-mãe, por que as pessoas tiram sarro de mim que eu sou filho de portador?" Falam na escola.

Eu respondo: "Vocês amam seus pais? Eu amo. Então, vocês não devem se importar com os outros, 
porque quem dá de comer e beber, faz compra, é a mãe e o pai, mesmo não podendo, a gente faz de tudo, então vocês não devem dar o lado/ouvido, escutar o que as pessoas falam, porque tem pessoas que não aceitam, sabe?" Têm medo, eles não convivem com a gente, acha que encostar já tá pegando a doença, mas, não é assim... eu percebo. Só que meus filhos não pensam dessa maneira, eles vêm abraçam, beijam o rosto, conversam e pedem explicação, porque eles estão crescendo, estão numa fase, que querem saber: Por que pegou? Como foi? Como pega? Então, eles têm medo, se previnem... Eles querem saber pra mais tarde não acontecer isso com eles, também.

Eu descobri na gravidez do M. O R tem 14 anos e a R 12, eles já pensam, conversam muito comigo; mãe graças a Deus não deu nada com o M, negativou e com a J, "será que minha irmã vai ter esse problema?" Não, eu fiz tratamento direito, estou dando o medicamento, eu tenho fé que ela não tem. Ai mãe, dá medo, mãe, medo de ver o nenezinho, assim com a doença, que nem a senhora, porque o nenê é tão frágil, não vai agüentar...

Hoje eu vou chegar e eles vão perguntar: - "Como foi o exame? Eles estão ansiosos. Se a senhora chegar na clínica, a médica falar "deu negativo", a gente vai ficar superfeliz. Estão na expectativa que vai dar negativo. Mãe: “Fazendo o tratamento direito, vai dar tudo certo, né?”.

Dezembro de 2007: o lactente com 1 ano e 6 meses em acompanhamento na clínica.

\section{Binômio 9}

Esta dupla mãe-pai foi excluída do estudo, pois a mãe participou da 1. 'dinâmica, porém não realizou a colagem, e na 2. ${ }^{\text {a }}$ abordagem se recusou a fazê-la. Uma vez que todos os casais já estavam identificados, optei por manter a numeração original.

\section{Binômio 10}

Mãe, 33 anos, ensino médio, católica, auxiliar de cozinha, separada, tem cinco filhos (14, 13, 3 e 2 anos, e o bebê) dois filhos são do primeiro parceiro, dois filhos do segundo - foi infectada por ele, que era usuário de drogas (o bebê é do terceiro companheiro). Não se percebia em risco para o HIV, soropositiva há 4 anos, descobriu durante o pré-natal do terceiro filho. Pai, 22 anos, ensino médio, auxiliar 
de padeiro, divorciado, um filho, mãe desconhece o tempo de positividade do parceiro, que está internado e cujas informações a seu respeito foram fornecidas por ela. Mãe participou sozinha de ambas as dinâmicas/entrevistas.

Iniciou o pré-natal com 36 2/7 semanas de gestação, parto normal, internação em período expulsivo, realizada a terceira fase do protocolo 076, não sofreu laqueadura tubária.

\section{Montagem 10A}

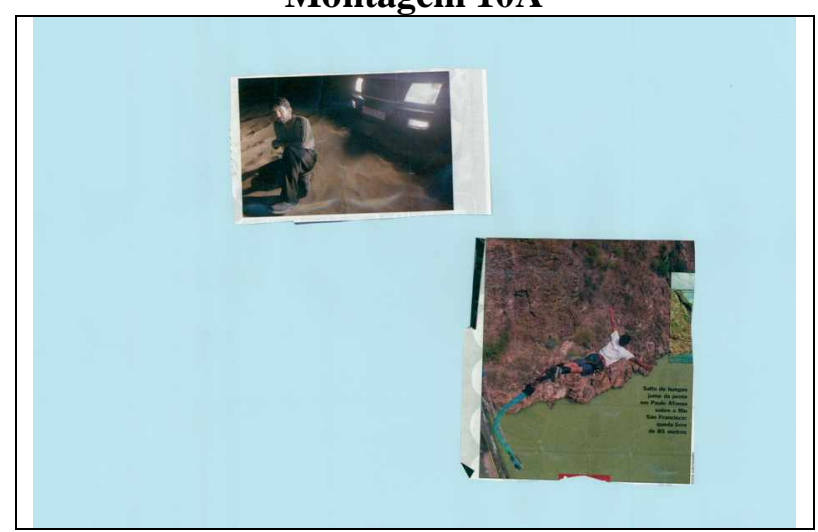

\section{Narrativa 10A}

Não tem o que fazer, tem que esperar, entendeu? É isso aí, tem que ficar e esperar. Não fazer mais nada.

É uma adrenalina. Tanto pode ser sim como pode ser não. Mas, fazer o quê? Esperar que não, que não, sei lá... É difícil falar... Ah! É assim pra mim, eu fico parada ali esperando, esperando o

resultado, mas não tem o que fazer, tem que esperar, entendeu? É isso aí, tem que ficar e esperar. Não fazer mais nada. E a outra gravura é tipo assim, quando, como eu posso explicar?

A gente fica assim, a gente se joga, é... complicado... arriscar... a gente fica esperando, a gente se joga, joga num lugar para esperar a decisão Daquele lá de cima, só por Ele mesmo, entendeu? Tipo assim, eu sabia, eu sabia, tenho dois filhos... Foi burrada, uma loucura, é difícil... Difícil...

Aqui ele voando, eu acho que meu filho vai ser livre, vai se livrar disso, vai viver, vai conseguir...

\section{Montagem 10B}

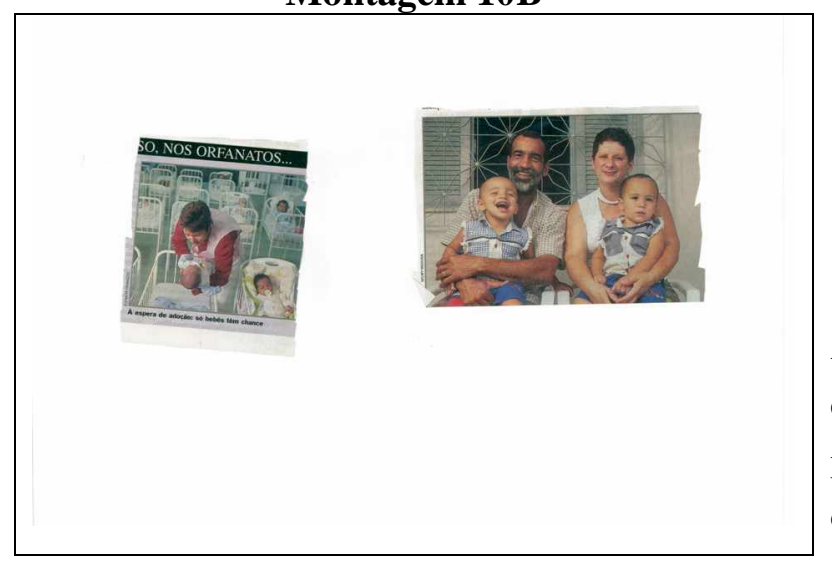

\section{Narrativa 10B}

A espera é muito dolorosa, tem hora a maternidade é bonita, mas nesta situação... Queria ter filho normal, pegar e dar de mamar pro meus filhos no peito, coisa que eu fiz com os outros...

A espera é difícil, é dolorida, ainda mais quando você não tem com quem falar, porque eu não tenho com quem conversar na minha casa... Não tem com 
quem conversar, são ignorantes. Minha mãe sabe do meu problema e uma irmã também, mas, mesmo assim é difícil, porque não dá pra ficar conversando, ficar falando as coisas... É meio complicado... A espera é dolorosa, muito dolorosa... Quando tá no primeiro exame, na segunda a gente sabe, que vai dar positivo, vai dando 1 ano... É pior ainda... Bem pior. Será que vai negativar? Por exemplo, minha filha, que tive antes dele, foi pra São Paulo, tomou o coquetel e teve uma série de "coisas" e fiquei com aquilo só pra mim, não dava pra conversar com mãe, com irmã, com ninguém, sabe? Então, foi difícil, não dá pra contar pros outros... Porque, embora minha mãe saiba que eu tenho, ela tem... é do ser humano mesmo, minha irmã mesma coisa, sou eu e sou eu... Por isso que eu choro desse jeito...

A outra vó dele nem sabe, mas mesmo que ela souber, eu acho que é indiferente pra ela. É... eu ainda vou ser feliz com meus filhos. Ah! Vou... Com certeza vou... muito. Até Deus querer, né? Se Deus quiser ele também vai negativar. Os outros filhos negativaram, só a do meio que teve esse problema, mas negativou também.

A espera é muito dolorosa, a maternidade é bonita, mas nesta situação... Queria ter filho normal, pegar e dar de mamar pro meus filhos no peito, coisa que eu fiz com os outros...

Mamaram sem limite, até quando quiseram, agora, não!!! Pega um pouco de friagem, fica meio assim... Porque eu não sei o que pode dar, até um ano e nove meses, difícil, muito difícil...

Eu vou ser assim... ainda nós vamos ser felizes, eu... minhas crianças... Tenho cinco, dois moços já, duas vão continuar morando até eu viver, se Deus quiser.

Conversar ajuda bastante. A gente precisa conversar. Não só porque tenho o HIV, é certo que tem, mas para minha família, minha mãe, eu não posso dizer minha mãe, que ela tem culpa, quem procurou fui eu. Não procurei, veio, aconteceu... A gente precisa conversar, quando tem que ver o resultado de um exame meu: dá isso, dá aquilo, poxa, a cabeça a mil. Não sabe o que fala, o que acha, o que é. É difícil... Às vezes converso com a psicóloga, é um chororô também, aqui um pouquinho mais, é difícil... E o dia que eu cair de cama então? Como vai ser?

O dia que eu ficar doente, sei lá? Isso pode acontecer. Eu não penso... eu não penso tanto assim, em mim, eu penso nos meus filhos, são muito pequenos, quero deixá-los pelo menos do tamanho dos dois primeiros com 14 e 15 anos, que já se viram sozinhos.

É... Eu vou chegar lá..., filho, eu vou, vou chegar aí nessa gravura.

Dezembro de 2007: o lactente com 1 ano e 6 meses, diagnóstico negativo para o HIV.

\section{Binômio 11}

Mãe, 33 anos, ensino fundamental, vendedora, católica, amasiada, tem três filhos (11 e 9 anos, e o bebê), não se percebia em risco para o HIV, soropositiva há 6 anos, foi infectada pelo ex-namorado, adesão ao tratamento há 6 anos. Pai, 28 
anos, ensino fundamental, soronegativo, presidiário, católico, amasiado, um filho. As informações sobre o pai foram fornecidas pela mãe, que compareceu sozinha para dinâmicas/entrevistas.

Parto cesárea, atenção ao protocolo 076, sofreu laqueadura tubária.

Montagem 11A

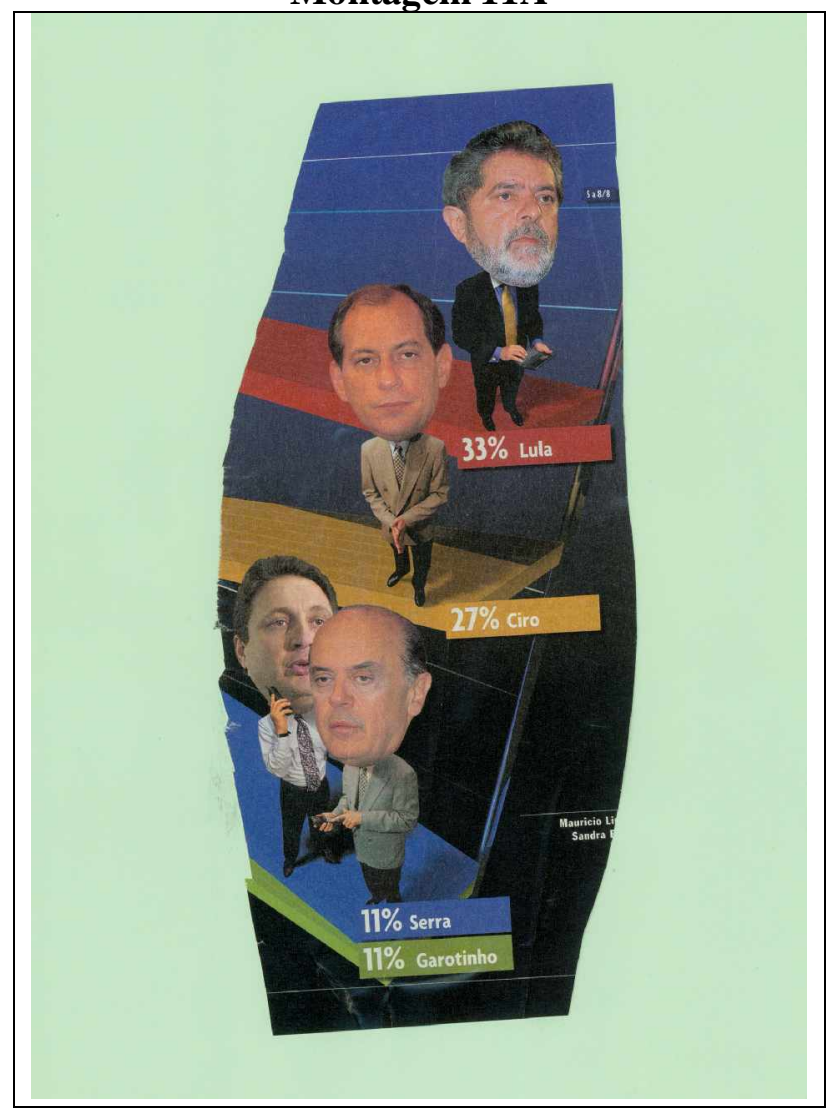

\section{Narrativa 11A}

A gente tem muito exame pra fazer, pegar remédio. Quando estava grávida dele eu tinha que fazer muito exame, então, serviço nenhum quer que a gente falte muito, começou a faltar, você leva muito atestado, eles te mandam embora.

Ansiedade, curiosidade, que seja negativado, principalmente isso. Acho que o que a gente tem, não quer para ele, fica pra gente. A política é uma coisa, uma vergonha, tem que melhorar mais, principalmente pra gente que tem esse tipo de problema... Mais emprego, mais ajuda que a gente não tem... ter mais ajuda do INSS, uma ajuda por fora, você já trabalhou muito, o que tem na carteira não conta.

Já tentei, é muito burocrático. Você tem

que correr demais para conseguir alguma coisa. Emprego ninguém dá, porque chegar pra pessoa e contar sua situação, não dá. Então, fica difícil você faltar no serviço porque tem sempre exame, tem que sempre estar vindo aqui na clínica, como vai justificar tanta falta? Você leva o atestado da clínica, eu fui mandada embora exatamente por causa desse problema, eu trabalhava de empregada doméstica e levei o atestado da clínica de DST e na outra semana ela me mandou embora, não falou o motivo, ela falou assim: que mandou eu descansar. Só isso.

Eu faltava só quando vinha na clínica. Esse é o problema, porque a gente tem muito exame pra fazer, pegar remédio. Quando estava grávida dele eu tinha que fazer muito exame, então, serviço nenhum quer que a gente falte muito, começou a faltar, você leva muito atestado, eles te mandam embora.

Os políticos tinham que fazer mais pela gente, tinham que dar mais apoio, só a carteirinha do ônibus que eles dão não basta. O apoio que eu falo é financeiro, você não tem, você toma os remédios que são superforte, não tem um leite pra tomar, não tem alimentação direito. Eu tomei os remédios com 
água, tinha que tomar 12 com água. É complicado, o estômago não agüenta. Na minha casa não tem praticamente nada.

Estou trabalhando em casa, não tem como ele (companheiro) ajudar, porque ele nunca trabalhou, era pra ele receber auxílio reclusão, mas ele nunca contribuiu com o INSS, não recebe... Acho que os presos deveriam ter também um direito, os filhos pelo menos.

A gente tem que ter mais auxílio. Ter essa doença é complicado... Você vai contar pra alguém? Só discriminação... Vai ter só discriminação... A gente tem direito a usar a carteirinha, no terminal o cara desconfia: "Tem o passe, mas tão nova?" Explicar o quê? E se fosse um cartão ao invés de carteirinha, que passava na catraca, evitava mostrar a carteira, ficar dando satisfação...

Quando entra pela porta traseira do ônibus, todo mundo olha: "Por quê? Tão nova? Por que carteirinha?" Esse é o problema... Acho que devia ter o cartão ao invés da carteirinha.

\section{Montagem 11B}

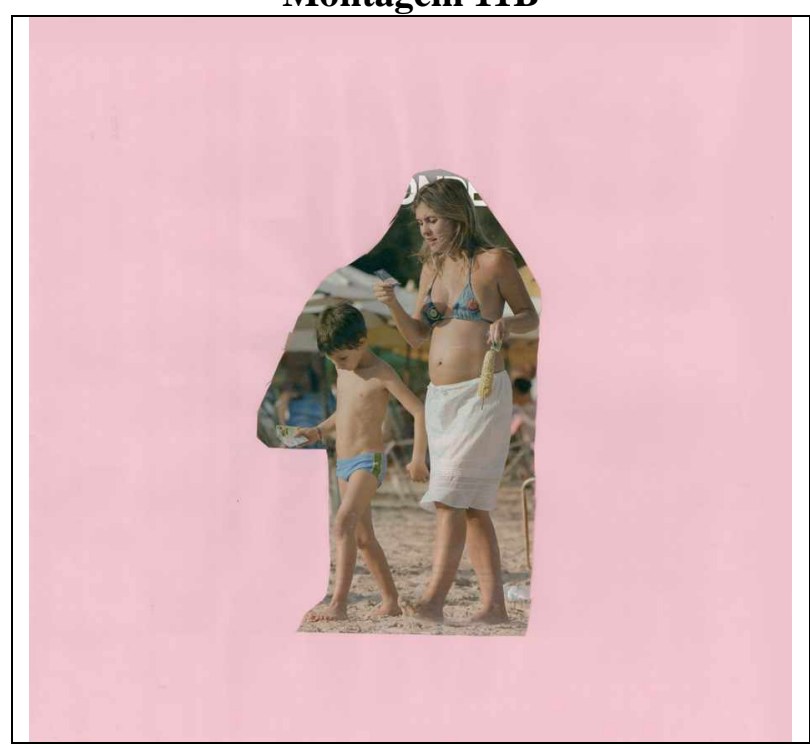

\section{Narrativa 11B}

A gente quer tudo de bom, saúde, não aquilo que você tem, é uma doença que é difícil de carregar, é tão difícil de agüentar, tem tanto preconceito.

O resultado que a gente aguarda é que seja bom. Na gravura ele já está grande, a gente pensa com esse objetivo, que ele esteja assim amanhã, andando na praia, saudável, principalmente aquilo que tenho, não quero que ele tenha. A gente sofre em dobro, já pensou amanhã, quando ele tiver 12 anos e souber que

tem esse problema?Então, eu aguardo um resultado positivo dele e nunca negativo, fica naquela expectativa. Imagino meu filho com 12 anos, porque quando eu descobri foi um choque, nossa... Então, pra ele vai ser a mesma coisa, já pensou ele com 12 anos? Como será que ele vai reagir? A vida dele vai começar com um problema desses? Como vai ser a cabeça dele?

É uma montagem bonita de mãe pra filho, a gente quer tudo de bom, saúde, não aquilo que você tem, é uma doença que é difícil de carregar, é tão difícil de agüentar, tem tanto preconceito.

Imagina amanhã ou depois na idade dele, como vai estar nosso país? A gente tem tanto preconceito, não somos aceitas em todos os lugares, você não arruma emprego, você falar que tem o problema, eles não vão lhe dar oportunidade jamais. Eles acham que você é inválida, não tem capacidade de trabalhar, então, é complicado. Eu quero que ele seja um menino saudável.

Esse preconceito tem em todos os lugares, independente da doença, até as pessoas que são deficientes, são débeis mentais também sofre (preconceito). A pessoa saber que a criança tem o vírus do HIV 
numa escola, não vão querer aceitar, vão achar que ele vai machucar um aluno e vai passar o vírus e vão comentar na escola. Imagina a cabeça da criança na escola com doença, já vão falar que tem o vírus. Não vão falar que ele tem o vírus, vão falar que tem aids bem declarado. É complicado isso pra uma criança, porque aqui não tem colégio específico pra estudar aquelas crianças. Se na escola descobre, acho que o preconceito da criança vai ser grande. Algumas mães podem pensar: Será que as crianças vão se machucar? Já vai passar, vão querer deixar as carteiras separadas da criança, porque acham que vai pegar no assento, tem tudo isso, a gente sabe que tem.

Eu tava no posto de saúde, tinha um rapaz supermagro, coitado, aquele rapaz nem tinha aids, a senhora olhou pra mim e falou: Não senta, você viu como ele está? Ele tem aids, vai pegar em você. Então, aquilo pra mim nossa! foi mesmo que... mas ele tá tossindo, pode ser até outro tipo de doença. Eu cheguei pra coordenadora do posto e perguntei o que o rapaz tem, coitado ele está com broncopneumonia, não tem nada a ver, ele não tem câncer, nem aids. O preconceito é grande, enorme... Eu não falo pra ninguém que eu tenho, porque se eu falar eu sei que tem preconceito, então, eu não comento. Nesse período é muito nervosismo, eu fico ansiosa, porque eu o vejo perfeito, tão lindo, tão bonito, ele sorri, eu fico com aquela consciência pesada. Ai, meu Deus, espero que ele não tenha esse vírus, dói a minha consciência em saber que eu tenho e posso ter passado pra ele, entendeu? Dói, dói muito... dói muito a consciência... demais até... Às vezes, à noite, eu deito e fico olhando pra ele e rezo pedindo a Deus que o exame seja sempre negativado e não positivo, confio em Deus que vai ser, né?

Na minha família ninguém sabe, espero que ninguém fique sabendo, minha família é do Norte e não vai entender, eles acham que já está à beira da morte, como eu já tenho dois filhos, ela não vai querer misturar, minha mãe é muito preconceituosa... O pessoal do Norte não entende como que é isso, acha que passa no conversar, é muito complicado explicar a situação, eu prefiro ficar só pra mim, uma coisa que é só minha.

Eu passo ele aqui na clínica, mas falo que tô indo na Santa Casa e assim vai indo...

É uma situação bem difícil, mas superável. Tenho um supercontrole, sabe, não me desespero, se tem que tomar remédio eu tomo, se tem que dar medicação pra ele, eu dou em dia, hora certa, sempre aguardando na esperança que ele seja negativado, se Deus quiser. Nosso país é um país que entra política, sai política, as coisas ficam as mesmas, ainda bem que tem essa clínica que a gente é bem atendida. Em São Paulo, você chega e não é bem atendido, o médico mal olha pra você, mal pega na sua mão. O pessoal da clínica DST já conversa mais com a gente, é mais aberto... Graças a Deus... Pelo amor de Deus, você vai com a mente meia doida, já vem meio tumultuada, a cabeça não é boa, chegar num lugar onde você não é bem recebida, fica pior ainda. Mas aqui, graças a Deus, eu sou bem atendida, e isso ajuda até a gente superar a doença. Por você ser bem atendido, você tem coragem de lutar contra a doença. Em São Paulo não tava dando mais, não tava nem passando. O Emílio Ribas é horrível, é um hospital que tem um péssimo atendimento. Então, você perde a vontade de viver, a vontade e coragem de correr atrás e sobreviver, e aqui não, já anima mais, graças a Deus. 
Dezembro de 2007: lactente com 1 ano e 6 meses em acompanhamento na clínica.

\section{Binômio 12}

Mãe, 23 anos, ensino médio, católica, faxineira, amasiada, não se percebia em risco para o HIV, primeiro filho de ambos, soube da soropositividade durante o pré-natal (terceiro mês de gestação) adesão ao tratamento há 9 meses. Pai, 25 anos, ensino médio, católico, repositor de supermercado, soropositivo, não compareceu às consultas com $\mathrm{o}$ pediatra, mas participou das duas dinâmicas/entrevistas.

Parto cesárea, atenção ao protocolo 076 e não realizou laqueadura tubária.

\section{Montagem 12A}

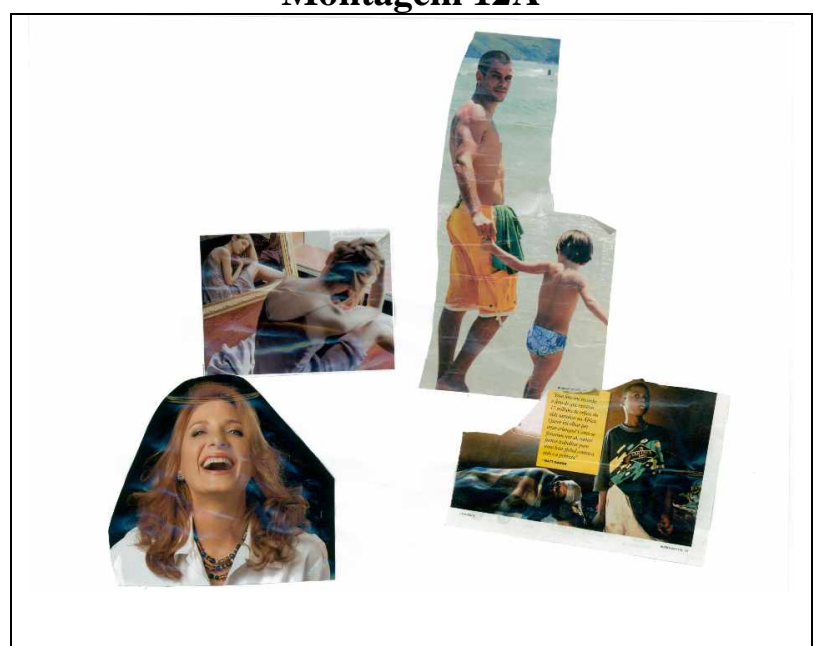

Narrativa 12 A

É um pouco de insegurança, medo, eu tenho mais que ela, a gente sente muita culpa.

Esperando um dia estar com ele num lugar assim... É esperança, assim que possa surfar... Pô, sei lá... a gente tem quase certeza que ele vai se salvar, agora nós, não sei, então, esperança. É um pouco de insegurança, medo, eu tenho mais que ela (mãe), a gente sente muita culpa.

A gente não sabe como foi, mas a culpa acho que fui eu... Você sente a culpa... Tem dia que a gente não tá legal... Não fisicamente, não tá legal, porque fica na cabeça, a gente vai trabalhar, chega em casa, fica difícil de encarar... daí é problema. No trabalho distrai, tenho que fazer outras coisas, não fica só fixado nisso... O sentimento depende do dia, você esquece da situação, depois vem um sentimento de viver. A nossa família não sabe, só a tia e o tio dela, que foi a pessoa com quem conversei, porque no dia foi difícil, precisava falar com alguém.

Como que as pessoas vão encarar nós depois? Isso que é pior e a gente não deve nada a ninguém...

Nós descuidamos. Se foi meu caso? Se foi ela? Pra mim é a esperança de uma coisa melhor neste 
lugar... Apesar de ter esse problema, eu sempre pensei muito alto, sabe? Mas nunca deu certo de encaixar, mas essa situação ainda é duro...

Mãe contente, sorrindo: fico sozinha o dia inteiro... Eu fico assim... Eu ajo normal, como eu tento esquecer, sabe? Não ficar com isso me perturbando, porque isso já o perturba, eu não gosto, não fico me perturbando. Eu não fico como ele (companheiro), debatendo, falando toda hora, chorando por isso, porque se eu chorar não vai resolver, o que eu fizer não vai resolver, o que aconteceu, aconteceu. Na gravura de cima, eu fico olhando assim... no espelho, fico pensando... Como vai ser? Vai dar tudo certo ou não? Eu espero que seja negativo, e que dê tudo certo. Meu dia-a-dia é normal, eu não fico ligando, que os outros fiquem sabendo. Na clínica eu já encontrei a sogra da minha prima e ela saiu contando... Eu pedi pra não contar, porque ninguém sabia e mesmo assim saiu falando, mas não devo nada pra ninguém, ninguém vem na minha casa perguntar se está faltando alguma coisa. Quem paga as minhas contas sou eu, pago meu aluguel, ninguém tem nada a ver com a minha vida.

Quando vou à clínica meu medo é encontrar pessoas que possam conhecer a gente, não tá nem aí, tá com problema, e tipo eu peço para não comentar nada com ninguém, a pessoa vai e fala porque acha que não tem nada a perder. Por isso que muitas pessoas ficam revoltadas, você fica revoltado, não, não estou... Mas, tem pessoas que é revoltado porque a situação é horrível, sentimento de vergonha, nossa, só quem passa, pra... saber.

No dia que fui ganhar o nenê também, lembra que eu falei pra doutora I que não queria ir na Santa Casa, porque tinha uma colega da gente que trabalhava lá. Ela descobriu, mas não comentou nada, somente com o namorado, que é superamigo dele (companheiro), desde criança. Ele veio, me abraçou e falou que vai me ajudar... Ele (bebê) nasceu no aniversário dele, daí nossa!!! ele tava contentão, mesmo com esse problema ele me abraçou, mas é horrível.

Meu marido tem muito medo de ver a minha família, porque a família dela (mãe) me acolheu muito bem, tenho medo que eles saibam, você olhar pra pessoa que gosta de você, é estranho... É uma coisa que eu não sei como vai ser, se um dia eu tiver que falar...

O nosso apoio é com a gente mesmo. Capaz que preocupe mais as pessoas ainda, eles que não têm nada a ver. Esperando dias melhores. Toda vez que eu penso que estou ruim, vejo pessoas em situação bem pior, pra não reclamar da vida. Como trabalho no mercado, fico exposto às pessoas, por isso que eu tento me esconder o máximo quando vou na clínica... Se chegar na boca do patrão, pode querer dispensar a gente, sei lá. Eu fico pensando um monte de besteira. Interessante que depois que aconteceu isso comigo, até melhorei, criei responsabilidade, porque tenho medo da vida, antes eu não dava valor à vida, não tava nem aí, sabe? Começa a segurar a vida, por que não segura antes, tenta equilibrar antes?

Ele sabe que tem gente há muito tempo com essa doença, mas ele acha que vai morrer logo... A gente fica pensando nele... fica... tipo, a turma fala: "Ah! Se você pegar uma doença você vai...” só que a gente tem uma fraqueza a menos... uma coisa a menos, fico pensando, vem na cabeça, fico meio perturbado nessa hora, mas, mesmo assim ... não agrido ninguém, fica pra mim, só que dói, tem hora... segurando... 
Montagem 12B

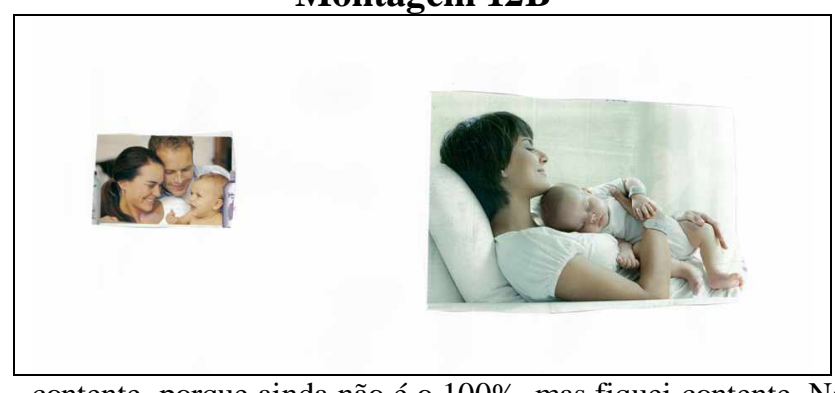

Narrativa 12B

Estou dando mais valor agora pra vida. A gente ficar doente, $o$ medo é deixar ele, o meu maior medo é esse...

O resultado dele (bebê) fiquei contente. Ah! fiquei e não fiquei

contente, porque ainda não é o $100 \%$, mas fiquei contente. Na hora que ela contou, eu fiquei contente, mas não tanto assim, por não ser 100\%. Pra mim, acho o melhor possível, de ver ele assim... Bem, espero poder acompanhar ele, estar bem, até quando a gente vai conseguir? ... É porque agora nós estamos bem, normal... Meu medo é da gente pegar uma doença, estou dando mais valor agora pra vida. A gente ficar doente, o medo é deixar ele, o meu maior medo é esse... A criança tem muita chance e o medo na gente é não conseguir igual outras crianças, negativar. Por que ele não? Já pensou, ele não conseguirá? Penso besteira, um monte de coisa ruim, isso que é duro...

Nós estamos felizes por ter negativado. Nossa!!! É o que mais quero que aconteça, superfeliz, tomara que logo esteja negativo de verdade, até fiz uma promessa pra Nossa Senhora Aparecida pra negativar, vou levá-lo em Aparecida. Vou marcar uma passagem, já que está negativando, estou super feliz. E o outro é satisfação, satisfação enorme de ter ele, forte, cheio de saúde, estar crescendo, lindão... Graças a Deus! Fico muito ansiosa pra saber o resultado, esperando que passe rápido pra fazer e ver o resultado, a gente fica aflita... A gente conversa muito sobre isso, não vê a hora de negativar rápido, e que encontre também uma cura.

Uma satisfação que tenho... a mãe com o nenê, tão satisfeita com o nenenzinho no colo, deitado nela... É um peso que a gente tira, é isso que estou sentindo... estou Feliz.

Dezembro de 2007: lactente com 1 ano e 6 meses em acompanhamento na clínica. 


\section{DESENHANDO O TEMA CENTRAL}

No capítulo anterior, tomou-se conhecimento das expectativas e ações da mãe e do pai à espera da confirmação do diagnóstico da criança diante da realização do teste anti-HIV. Passo, a seguir, a apresentar o tratamento dado às narrativas segundo preconizado por Hammersley e Atkinson (1995), citado anteriormente.

O tratamento dos dados obtidos permitiu capturar as experiências que cada dupla mãe-pai vivencia nesse período de incertezas enquanto aguarda a confirmação do diagnóstico para o HIV do filho. A extração de trechos das narrativas, considerados relevantes para o estudo, e sua categorização por similaridades temáticas gerou 11 subtemas que apresentavam similaridade e conexão: Esperança e confiança; Sentimentos; Ansiedade e expectativa; Espiritualidade/Religiosidade; Apoio; Relacionamento familiar; Preocupação com a saúde do filho; Cuidado e tratamento; Preconceito; Soropositividade e Fazendo analogia.

Tais subtemas aglutinados levaram à identificação de temas: Sentimentos, Espiritualidade/Religiosidade, Apoio, Preocupação com a saúde do filho, Preconceito e Fazendo analogia. O agrupamento destes subtemas caracterizou, preliminarmente, a VIVÊNCIA desses pais, conforme a Figura 7, a seguir: 


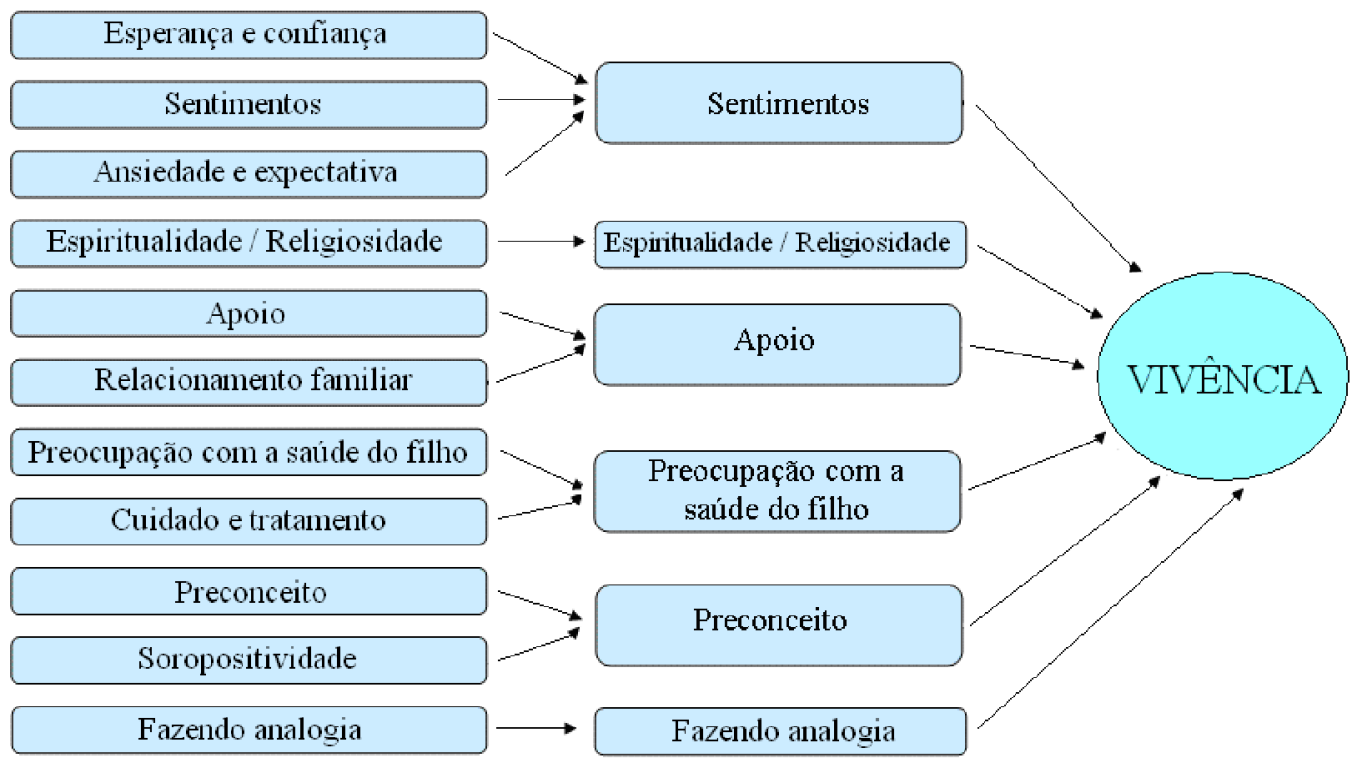

Figura 7 - Diagrama dos Temas e Subtemas.

Para esta fase do estudo optei por trabalhar os dados das narrativas sem distinção do período de vida do lactente em que foram obtidas. Isso se deveu à similaridade de conteúdo dos dois momentos pertinentes às dinâmicas.

Os dados indicaram que cada dupla de mãe-pai enfrenta de maneira única as circunstâncias relativas à situação em que vive, porém destaco algumas características comuns que, agrupadas nos temas, convergiram para a VIVÊNCIA.

No processo de construção da fase de categorização dos dados, percebi que a configuração utilizada para demonstrar a trajetória de análise desses dados não era suficiente para explicar os resultados obtidos, pois estavam linearmente dispostos (Figura 7), sendo que, ante a realidade dos fatos, eles eram circundantes, por isso senti a necessidade de realizar uma explanação espacial que permitisse "enxergar" e melhorar as possibilidades de interpretação e de compreensão das experiências dos informantes em relação à situação vivida.

Essa explicação se materializou na construção de um diagrama (Figura 8) com os temas apresentados isoladamente, interligados pela VIVÊNCIA, contudo são temas abrangentes com aspectos mútuos, que conduzem a uma reciprocidade. 


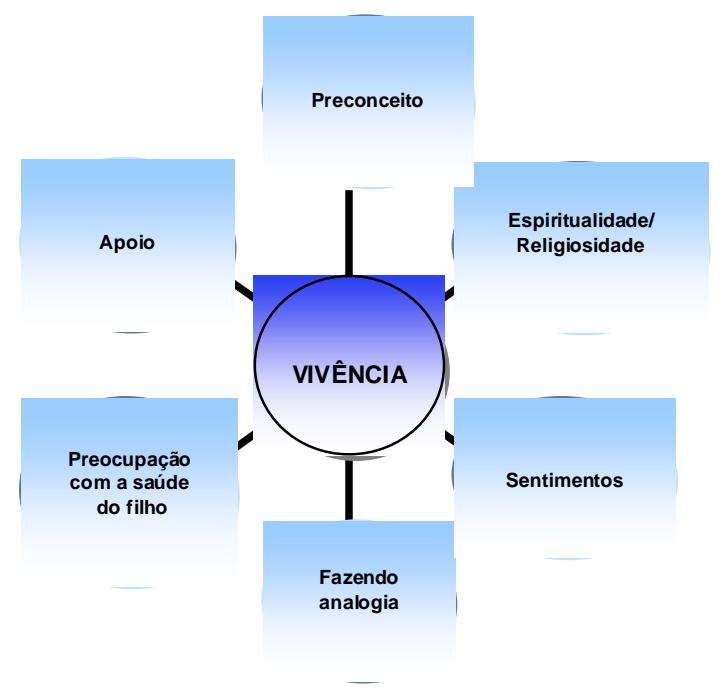

Figura 8 - Diagrama ilustrativo dos Temas Analisados - fase 1.

Assim, neste momento, ao aprofundar a leitura/pesquisa, levou-me a uma reflexão, cujos temas, embora apresentados isoladamente (Figura 8), imbricavam-se entre si, isto é, inter-relacionavam-se, o que me levou a ajustar o diagrama para que representasse a situação como segue:

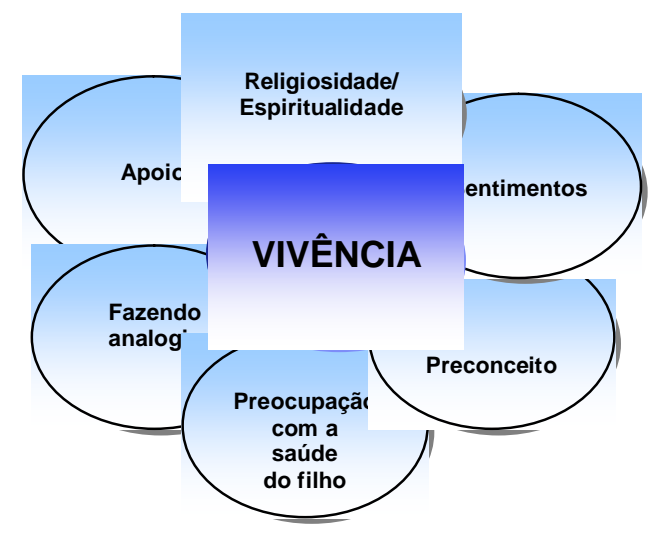

Figura 9 - Diagrama ilustrativo dos Temas Analisados - fase 2.

Esta nova configuração mostra os temas se ligam estreitamente, evidenciando a correspondência entre si, além de facilitar o exame e a compreensão 
dos resultados, esclarecendo ao leitor e expressando os dados encontrados neste estudo.

Ao desmembrar as narrativas e categorizar os trechos selecionados, verifiquei que, para a maioria das mães e pais, a gravidez representou uma felicidade entrelaçada com a preocupação da saúde do filho, que os motivou a submeterem-se ao acompanhamento e ao tratamento anti-HIV na gestação, no parto, no puerpério, e o mesmo procedimento ocorrendo com o recém-nascido.

Ao realizar o levantamento da bibliografia pertinente à temática, deparei-me com muitos estudos dirigidos a gestantes soropositivas (Barbosa, 2001; Abeyá et al., 2004; Cunha, 2004; Landroni, 2004; Azevedo, Guilhem, 2005; Carvalho, Piccinini, 2006; Moura, Praça, 2006) e um número menor de trabalhos voltados às mulheres no pós-parto, sendo recomendado em artigo de Carvalho, Piccinini (2006) a necessidade de estudar a maternidade após a chegada do filho.

O período pós-parto, em mulheres soronegativas, já denota uma série de alterações físicas e psíquicas, pois passam da condição de filhas/mulheres para de mães, vivenciam momentos de turbulência, exigindo uma adaptação psicossocial, amparo no apoio da família e nos serviços de saúde, para fortalecer o suporte emocional que necessitam.

Vale ressaltar que, a seguir, discorrerei sobre a apresentação e a discussão dos resultados nos quais serão registrados trechos das narrativas relacionadas a cada tema para exemplificá-los. Estas frases são identificadas pelo número de ordem correspondente à dupla mãe-pai, que as referiu, enquanto que as letras "A" ou "B", que o acompanha, referem-se à entrevista realizada no terceiro ou no quinto mês de vida do lactente, respectivamente.

A seguir, apresentarei cada tema e os subtemas correspondentes.

\subsection{SENTIMENTOS}

O tema nomeado Sentimentos derivou-se dos subtemas: Sentimentos, Esperança e confiança, Ansiedade e expectativa, no qual busquei agrupar os fatores 
da afetividade e sensibilidade, que foram considerados relevantes e expressivos na narrativa dos participantes deste estudo.

Ao laborar nesses três subtemas foi possível constatar uma amplitude de sentimentos aflorados em um momento especial da vida do pai e da mãe com a chegada do filho. Essa capacidade de sentir caracterizou-se por situações contraditórias, com polarizações de sentimentos, que permeiam esse período, variando entre positivos, como esperança, confiança, e negativos, como ansiedade, culpa e medo.

Como se pode constatar pela frase do pai:

A gente tem quase certeza que ele vai se salvar, agora nós, não sei, então, esperança. É um pouco de insegurança, medo, eu tenho mais que ela, a gente sente muita culpa. (12A)

O subtema Sentimentos sintetiza essa mescla de emoções dos pais, apresentando satisfação com a gravidez, amor e felicidade com o filho, mas também, preocupação com a situação de sua exposição, destacada principalmente, pelo medo de sua infecção, da mesma forma em relação à possibilidade de adoecimento e de finitude da vida, o que impossibilita o acompanhamento do crescimento do filho. Contudo, são instados a enfrentar essa situação de expectativa, apoiados na devoção ao filho.

O pai diz que:

O resultado dele fiquei contente. Ah! fiquei e não fiquei contente, porque ainda não é o $100 \%$. (12 B)

Para muitas mulheres, a maternidade é seu destino social e a garantia do lugar psíquico da feminilidade; é uma experiência fundamental e estruturante da identidade feminina. Independente da classe social, a maternidade emerge como um atributo biológico que torna as mulheres como seres mais fortes. Este sentimento não é só manifestado pelas mulheres, porque os homens também querem exercer a paternidade, quer por razões religiosas, para dar sentido à vida, para a construção da sua identidade viril (Paiva et al., 2002; Sherr, Barry, 2004; Aguiar, Simões-Barbosa, 2006, Monticelli, Santos, Erdmann, 2007). Assim, a gravidez era um desejo, e essa 
vontade foi constatada tanto para as mães quanto para os pais, como afirmam:

Tinha vontade de ter um filho, sonhava com um filho, eu também queria ter um filho com ela... (3A)

O auge da satisfação e felicidade sobreveio com o nascimento do filho, uma vez que ultrapassados incômodos e dificuldades próprios da gestação, bem como de imprevistos do parto, que podem colocar em risco a vitalidade da criança, a presença do filho concretiza essa jornada. No entanto, esta afetividade contrapõe o temor de perder o bebê, que se constata no relato a seguir:

A gente poder estar com o nosso filho, tem várias mães que o filho tem esse negócio, muitas vezes, não vai pra frente, morre antes de nascer e eu, graças a Deus, tive a oportunidade de dar a luz. (1B)

Poder desfrutar da companhia do filho permitiu sentir emoções que envolvem a interação mãe-bebê, as quais foram configuradas como sentimentos positivos, representados pelo estado de contentamento, de muita felicidade e amor, desembocando na emoção que o filho trouxe, de dedicação absoluta, demonstrando a propensão ditada pelos laços familiares. As mães e pais contam que:

A mãe tomando banho junto com o filho numa banheira... Felicidade, alegria... Não importa o problema que tenha. (2A)

Essa gravura aqui é pelos dias felizes que nós estamos passando com ela. (4A)

E o outro é satisfação, satisfação enorme de ter ele, forte, cheio de saúde, estar crescendo, lindão... Graças a Deus! (12B)

Compreende-se que tal sentimento influencia no desenvolvimento da criança e nas suas relações sociais, bem como auxilia a mãe a desempenhar com maior competência seu papel materno.

Por outro lado, o sentido dado pelas mães e pais, durante as entrevistas, deixou transparecer os sentimentos de preocupação com a situação de 
exposição do filho, destacada, principalmente, por temer a sua infecção, o medo de transmissão do vírus ao bebê, situação também constatada por Sherlock, Vieira (1999); Pinheiro, Barroso (2004); Barroso et al. (2006); Silva I (2005); Neves, Gir (2006); Athaniel (2006), ao estudarem mães soropositivas que sabiam da susceptibilidade do bebê. As mães e pais afirmam que:

Por causa do problema você fica com medo, enquanto não tiver o resultado em mãos, não tem como a gente não ficar preocupada... (6B)

Tem medo, mesmo a gente que tem o HIV, encostar, não é fácil de pegar, mas mesmo assim, eu converso com meu marido sobre as crianças não terem, a gente evita muitas coisas, encostar nas crianças, ferimento, porque eu morro de medo de passar qualquer tipo de doença pras crianças. (8B)

Essa circunstância conduz mães e pais a experimentarem os sentimentos de desconforto, insegurança, sofrimento e medo culminando com a culpa, pela percepção de terem tido conduta negligente ou imprudente, e não estimaram ou mesmo desconhecerem a possibilidade da transmissão e dano do HIV. Os relatos seguintes mostram essa situação:

Nesse período é muito nervosismo, eu fico ansiosa, porque eu o vejo perfeito, tão lindo, tão bonito, ele sorri, eu fico com aquela consciência pesada. (11B)

Espero que ele não tenha esse vírus, dói a minha consciência em saber que eu tenho e posso ter passado pra ele. (11B)

A gente não sabe como foi, mas a culpa acho que fui eu... Você sente a culpa... (12A)

Sobre esse aspecto, os estudos de Paiva et al. (2002) e de Sherr, Barry (2004) apontaram que, apesar da alta proporção de homens que disseram sentir vontade de ter um filho, seu conhecimento sobre a transmissão do HIV pela via materno-infantil (TMI) era relativamente escasso, por sua vez, a taxa de mulheres informadas sobre TMI foi de $75 \%$. 
Outro fato que merece destaque é a preocupação com o adoecimento e a potencial ausência da mãe, por acreditarem que sua vida será curta, seja por não terem saúde suficiente para criar os filhos ou ocorrer problemas físicos decorrentes da infecção e da possibilidade de morte, os binômios deste estudo afirmam que:

E o dia que eu cair de cama, então, como vai ser? O dia que eu ficar doente, sei lá? Isso pode acontecer. Eu não penso... eu não penso tanto assim em mim, eu penso nos meus filhos, são muito pequenos... (10B)

Ele sabe que tem gente há muito tempo com essa doença, mas ele acha que vai morrer logo... (12A)

A gente ficar doente, o medo é deixar ele, o meu maior medo é esse... (12B)

Deixar os filhos em situação de insegurança ou desamparo, também, foi destacado por algumas mães e pais, pois nem todas as famílias conhecem a condição de soropositividade do binômio mãe-pai, como o relato constata:

Os outros dois não têm pai, se eu não tiver bem, como que eu vou fazer? Não tem lugar pra ir, não tem... Vai ter que mandar, um pra um lugar e o outro pra outro. Caso eu chegar a tombar mesmo, a cabeça explodir, eu penso nisso; eu quero os meus filhos junto comigo, comigo eles estão bem. Então, ficar com os outros? Separado, não! Fica complicado (2B)

Diante dessa circunstância é inevitável imergir sentimentos de medo e de insegurança, que foram atestados em outros estudos (Sherlock, Vieira, 1999; Pedro, Stöbaus, 2003; Pinheiro, Barroso, 2004; Souza, Vietta, 2004; Veras, Petracco, 2004; Azevedo, Guilhem, 2005; Silva I, 2005; Barroso et al., 2006; Athaniel, 2006; Carvalho, Piccinini, 2006; Neves, Gir, 2006).

O subtema Esperança e confiança exprime a sensação de segurança que sentem mães e pais, com o objetivo de alcançar um bem que desejam muito, este aparece em patamares, cujos degraus são representados pelo crescimento e desenvolvimento satisfatório da criança. Essa caminhada evidencia aspectos importantes, consubstanciados pelo desejo que o filho cresça e que os pais possam 
acompanhar esse crescimento, outra manifestação própria da dupla de pais é que o filho goze de plena saúde. Ressalta-se esse sentimento quando os pais relatam:

Eu quero que ele seja um menino saudável. (11B)

Todo dia eu acordo e penso... "eu desejo pra ela que ela cresça e cresça bem. Que essa doença não esteja com ela. Será que ela vai crescer todas as etapas da vida dela? Aí, isso fica na minha cabeça (...) Todo dia que eu acordo, eu desejo isso pra ela, que dê tudo certo o resultado”. (4A)

O benefício mais importante que a dupla pai-mãe espera para o filho relaciona-se ao resultado do teste anti-HIV, aguardam-no repletos de esperança na "cura", representada pela negativação do exame, ou seja, que o filho esteja livre do vírus. Assim, a "negativação" do exame é imperiosa, ficando evidente a dificuldade de aceitar a idéia de infecção do seu filho:

E a imagem do bebê, depois que eu fico sabendo, numa hora eu penso assim, que vai dar tudo certo, que a minha filha não tem nada, ela está bem de saúde, não tem nada, o sangue dela está limpo. (8A)

A esperança e a confiança no tratamento foram valorizadas pelos pais devido à sua capacidade de proporcionar conforto enquanto aguardam a "cura" da criança, além de minimizarem o próprio sofrimento motivado pela possibilidade de ter transmitido o vírus da aids ao filho, como afirmam mães e pais:

A gente faz tudo por um filho, acorda de madrugada pra dar o remédio certinho, né? Se a gente não cuida deles, quem vai cuidar? Lógico, a gente faz tudo por um filho... E o resultado do exame será feliz, porque eu sei, eu tenho certeza que a minha filha não vai ter isso... porque eu tomei o remédio certinho, estou dando o remédio certinho. (3A)

Todo dia que eu acordo eu desejo isso pra ela, que dê tudo certo o resultado, que ela vá crescendo, crescendo, e que a gente possa também crescer junto com ela. (4A) 
Os vários estudos realizados com mães soropositivas para o HIV apontam para a mesma direção, o sentimento de felicidade está presente e representa uma afirmação da vida, descoberta de novo sentido para a vida, impelindo uma vontade de viver, contrapondo uma das características da aids, como doença sem cura e letal.

Um aspecto considerado nos relatos foi a projeção manifestada para o futuro do filho, antevendo situações promissoras relacionadas à sua saúde, na qual um pensamento posto está na idéia de que planejar o futuro é essencial, consciente que a missão dos pais é a de educar e prover a sobrevivência, como constata-se no relato a seguir:

O essencial não é só ter, tem muita coisa, educação, os cuidados, planejar futuro. (2B)

Na gravura ele já está grande, a gente pensa com esse objetivo, que ele esteja assim amanhã, andando na praia, saudável, principalmente aquilo que tenho, não quero que ele tenha. (11B)

Embora o sentimento de esperança e confiança auxilie os pais a enfrentarem a expectativa do resultado do exame, este sentimento não é suficiente para anular a ansiedade gerada por essa circunstância. São 18 meses entre o nascimento e a definição do diagnóstico, esse período torna-se um fardo e os mantêm aprisionados no tempo, o resultado negativo do exame é aguardado com muita expectativa.

Essa espera é angustiante, um estado de grande inquietude, essa carência de resolução provoca sofrimento para algumas mães e pais como dizem:

Fico muito ansiosa pra saber o resultado, esperando que passe rápido pra fazer e ver o resultado, a gente fica aflita... (12B)

Eu fico naquela expectativa - meu Deus... Será que é a doença?

Eu fico parada ali esperando, esperando o resultado, mas não tem o que fazer, tem que esperar, entendeu? É isso aí, tem que ficar e esperar. Não fazer mais nada. (10A) 
O tema Sentimentos é marcado pela ambivalência dos sentimentos, que, ao se confrontarem, dimensionam o viver dos pais. Embora estas condições evoquem sentimentos pessimistas, é notável a força e a coragem com que alguns pais e mães revelam e mobilizam recursos para sustentar-se em uma situação difícil, em busca de alternativas de enfrentamento. Esse movimento implica no ponto de partida para a construção ou reconstrução da própria identidade, gerando a retomada de sua trajetória de vida e abrindo um novo caminho na vida destes pais. Os relatos a seguir ilustram esta condição.

Espero que eu consiga um emprego, entendeu? Que eu pare com meus vícios e que nada falte pra minha filha, poder tudo dar pra ela. (3B)

Mais interessante, parece que depois que aconteceu isso comigo, até melhorei, criei responsabilidade, porque tenho medo da vida, antes eu não dava valor à vida, não tava nem ai, sabe? (12A)

Neste tema Sentimentos foi possível apreender as emoções expressas pelas mães e pais diante da situação de indefinição do diagnóstico do filho exposto, principalmente, o afeto ao filho, que encoraja a busca de amparo, encontrada na religiosidade e espiritualidade, próximo tema a ser discutido.

\subsection{RELIGIOSIDADE/ESPIRITUALIDADE}

Neste tema abordarei uma das principais evidências das narrativas de pais e mães, dentre as ações identificadas referentes ao período de espera do diagnóstico para o HIV do filho, a fé que os pais dedicam à entidade religiosa expressa o suporte para enfrentarem a situação social e de infecção instaladas. A importância desta fé, enquanto recurso de luta contra os desafios da vida, principalmente, para suportar doenças fatais, pode surgir como um recurso interno que favorece a aceitação e o empenho no restabelecimento da doença, evita sentimentos doloroso, e torna-se fonte de fortalecimento para as pessoas.

Os relatos das mães e dos pais deste estudo oferecem subsídios de 
modo categórico sobre esse aspecto:

\author{
Mas, eu tenho fé que vai negativar sim, simboliza uma fé, a minha fé, se \\ não fosse a minha fé, a fé da minha família, ele não tinha... A fé é assim, \\ a gente se reúne e reza, a gente pede a Deus. (5B) \\ Rezo pedindo a Deus que o exame seja sempre negativado e não \\ positivo, confio em Deus que vai ser. (11B)
}

A Religiosidade e a Espiritualidade sempre foram consideradas importantes aliadas das pessoas que sofrem e/ou estão doentes, especialmente quando a cura médica não é possível influenciar no seu bem-estar (Sowell et al., 2000; Fleck et al., 2003; Kovács, 2007). Em estudos sobre religiosidade, destaca-se o resgate do tema na área da saúde, em que sua relevância ocorre pela importância da religião nas sociedades humanas, nas quais as pessoas atribuem a Deus o aparecimento ou a resolução dos problemas de saúde que as acometem e se apóiam na fé, como recurso cognitivo, emocional ou comportamental para enfrentar os seus infortúnios.

Este fato despertou interesse na comunidade científica para entender as implicações da espiritualidade no processo saúde-doença, inicialmente com pacientes com câncer e com doenças crônicas. Dada à complexidade do assunto e à diversidade de manifestações espirituais, de uma maneira geral, os estudos são limitados e não podem ser disciplinados ao estudo científico tradicional, pois não existe uma medida para a fé, ainda que já foram descritos vários instrumentos para mensuração de bem-estar espiritual (Saad, Masiero, Battistella, 2001).

A Organização Mundial da Saúde (OMS), estimulada e preocupada com a temática da qualidade de vida e bem-estar das pessoas, constituiu, em 1999, o Grupo de Qualidade de Vida com a finalidade de desenvolver instrumentos numa abordagem transcultural para avaliar a qualidade de vida, aliando a avaliação das medidas de impacto da doença com o comprometimento das atividades diárias, com base na percepção da saúde e de disfunção/status funcional, descrito por Fleck (2000), Fleck et al. (2000).

Esse grupo elaborou o WHOQOL-100 (World Health Organization Quality of Life Instrument - 100 itens), instrumento composto por 100 questões que 
abordam a qualidade de vida. Um dos aspectos identificados foi o domínio VI denominado "Espiritualidade, Religiosidade e Crenças Pessoais", no qual a dimensão espiritual foi estudada e foram emitidos conceitos pertinentes, uma vez que são utilizadas numerosas e complexas denominações comumente relacionadas a essa temática, tais como: fé, bem-estar espiritual, crenças religiosas e espirituais, prática religiosa, fé religiosa, entre outras, também suscitou o aprofundamento deste assunto, originando o instrumento WHOQOL-SRPB (Spirituality, Religiousness and Personal Beliefs).

Dessa forma, a espiritualidade abrange questões a respeito do significado da vida e da razão de viver, não se limitando a alguns tipos de crença ou práticas. A religião é definida como a crença na existência de um poder sobrenatural, criador e controlador do universo, que deu ao Homem uma natureza espiritual que continua a existir depois da morte de seu "corpo" e a religiosidade é a extensão na qual um indivíduo acredita, segue e pratica uma religião. Para crenças pessoais podem ser quaisquer crenças ou valores que um indivíduo sustenta e que formam a base de seu estilo de vida e de seu comportamento, processo descrito e aplicado por Fleck et al. (2003).

Trechos das narrativas dos pais e mães deste estudo exemplificam essas dimensões:

A fé é esperança, porque esperar algo que você não consegue ver é fé. A fé é você esperar algo que não existe, que ainda vai existir. Você estando firmado em Jesus você está seguro... (7A)

Enquanto estou aguardando, eu faço de tudo pra que dê certo, eu oro, peço pra Deus que dê tudo certo e que o exame... dê negativo, a gente cuida o máximo que pode. (8B)

A religiosidade também pode ser entendida como atributos relativos a uma religião específica, diferenciando-se de espiritualidade. Caracteriza a adesão a crenças e a práticas relativas a uma igreja ou instituição religiosa organizada, inclui aspectos individuais e institucionais. A espiritualidade é a relação estabelecida por uma pessoa com um ser ou uma força superior na qual ela acredita. É um fenômeno apenas individual, sensibilidade "extraconsciente". Também é definida como um 
sistema que enfoca elementos intangíveis, que transmite vitalidade e significado a acontecimentos da vida (Saad, Masiero, Battistella 2001):

A gente sempre pede a Deus pra que realmente Ele ponha a mão, não só pra ele (filho), mas todas as crianças. (2A)

Os estudos evidenciam que a fé e a crença desempenham um enorme papel na terapia, esse processo de cura pode mobilizar energias e iniciativas extremamente positivas, com potencial ilimitado para melhorar a qualidade de vida da pessoa, tanto em contexto de saúde como de doença (Sowell et al., 2000; Saad, Masiero, Battistella, 2001; Fleck et al., 2003; Marques, 2003; Luzardo, Waldman, 2004; Faria, Seidl, 2005; Pessini, 2007). O relato a seguir exemplifica esta afirmação:

Se Deus quiser ela não tem nada, não tem nada, será firme e forte. A gente sempre conversa nessa mesma tese. (4A)

Com o surgimento da aids, várias questões emergiram tanto da dimensão biológica, como psicológica e social, configurando um problema com repercussões na vida dos portadores, inclusive na perspectiva espiritual, que inclui conteúdos existenciais e geram significativas alterações na integração da espiritualidade com outras dimensões na vida dos infectados com HIV/Aids. Alguns relatam sentimento de abandono por Deus, como castigo.

Esse momento, de esperança e confiança, está ancorado na fé divina, é permeado na crença em Deus e se reveste em força, sendo valorizado pelos pais devido à sua capacidade de proporcionar conforto, como segue:

Eu estou com uma expectativa que vai dar tudo certo. Se Deus quiser, ele não tem nada. (1B)

Essa temática direcionou alguns estudos, junto aos portadores do HIV/Aids, homens e mulheres, para examinar o papel de atividades espirituais como um recurso que pode reduzir os efeitos negativos de fatores estressores relacionados à doença, tem se apresentado como um aspecto que pode ser intensificado ante da vivência da soropositividade. 
Alguns estudos demonstram que a valorização do sagrado e das práticas religiosas atuam como fator de proteção aos indivíduos infectados (Sowell et al., 2000; Soares, Nóbrega, Garcia, 2004; Faria, Seidl, 2005; Tarakeshwar, Khan, Sikkema, 2006; Litwinczuk, Groh, 2007). Estas atividades podem ir além de atendimento em igrejas, grupos de orações e leitura da Bíblia, sendo ampliadas as ações na direção da espiritualidade, como a renovação do compromisso com a vida, representados pela transformação dos objetivos de vida, aceitação da mortalidade e autocuidado, igualmente o relacionamento com a família.

A relação entre a Espiritualidade e o propósito de vida e o bem-estar mostrou ser um grande potencial para intervenções que incluem os aspectos positivos da espiritualidade e da luta que a pessoa com HIV pode experienciar, constituindo um recurso psicológico importante que responde a uma variabilidade individual, com reflexos na adaptação à enfermidade e aos cuidados e tratamentos.

Neste aspecto, destacou-se a interação da fé religiosa com a busca do bem-estar emocional, que podem ser identificados no relato de mães e pais:

Estou numa fé, numa certeza, tanto é que eu fiz uma promessa pra Nossa Senhora Aparecida me ajudar, desde quando descobri. Em junho na festa de Aparecidinha, vou levá-lo vestido de anjo, da catedral até a igreja de Aparecidinha. (1A)

Demonstrou-se que, especificamente, em abordagem sobre espiritualidade com gestantes e mães HIV positivas o envolvimento religioso esteve relacionado a estratégias mais ativas de enfrentamento da infecção e a maiores índices de apoio social, podendo servir como um mecanismo de redução da negação e, conseqüentemente, de prevenção do sofrimento psicológico. Atuando como fonte de interpretação para os acontecimentos da vida, a religiosidade pode representar apoio para o enfrentamento das dificuldades e para a mudança de atitudes. (Rose, Clark-Alexander, 1996; Sowell et al., 2000; Gray, Cason, 2002; Majundar, 2004; Prado et al., 2004).

Eu fiz o tratamento certo pra não passar nada pra ela. Eu tenho Deus no coração e tenho fé, a primeira coisa eu penso em Deus, e sei que eu posso ter, mas meus filhos não. (8A) 
Essa fé religiosa presente na vida do binômio mãe-pai de um lactente que, aguarda a definição do diagnóstico para o HIV e proporciona segurança e otimismo ante o tratamento e à intervenção instituída, pois os tornam capazes de lidar com essa situação. Neste aspecto, destacou-se a interação da fé religiosa com a busca do bem-estar emocional. Como exemplos, citam-se:

Eu creio em primeiro lugar com a ajuda de Deus e com a Medicina de hoje está bem mais avançada, com tratamento melhor, eu creio que melhore. Eu tô tranqüilo, a fé que tenho em Deus, creio que ela (bebê) não tem nada. (7B)

É isso que eu penso, só Deus mesmo, porque simboliza Deus, porque ela está pedindo a Deus, eu tenho fé que ele vai negativar logo. (5B)

A gente faz tudo por um filho (...) por mais que desse positivo, a gente também espera um pouco da Medicina, que hoje está bem avançada. Hoje em dia muitas coisas, muitas doenças que a gente sabe que de uma hora para outra, se for pela vontade de Deus, um dia vai ter cura. (4B)

De uma maneira geral, os dados são convergentes com os achados de estudos que imputam a fé em Deus e a força interior como sustentáculos imprescindíveis para a manutenção da saúde (Sherlock, Vieira, 1999; Simoni et al., 2000; Teixeira, 2003; Soares, Nóbrega, Garcia, 2004; Faria, Seidl, 2006; Carvalho et al., 2007).

A religiosidade é, portanto, parte relevante da vida das pessoas, pois sempre as acolhe e acalma, trazendo-lhes alívio. Seu discurso reconfortante fortalece-as para o enfrentamento de situações estressantes, incluindo vários aspectos da vida, não somente a cura da doença.

Sá, Pereira (2007) realizaram revisão histórica sobre espiritualidade em publicações no periódico da Revista Brasileira de Enfermagem, na década de 1950 até o ano de 1999 e encontraram 57 artigos sobre a temática, o que demonstra a atenção dispensada pelos enfermeiros brasileiros ao tema.

A importância dos estudos sobre espiritualidade reside no seu direcionamento sobre o cuidar das pessoas, esse conhecimento traz implicações para 
a prática de enfermagem, ao oferecer resultados que correlacionam a espiritualidade com o propósito de vida, há redefinição do significado dos eventos na vida das pessoas, e isto motiva a necessidade de mudanças na dinâmica de atendimento, pois é um potencial para intervenções, desenvolvendo um processo de convivência com o infortúnio, ao invés de ser um fim.

Concordo com Teixeira (2003); Litwinczuk, Groh (2007) quando valorizam a dimensão espiritual pelos profissionais de saúde como uma necessidade, com o propósito de entender essas crenças e ampliar esse conhecimento revertendo-o no bem-estar das pessoas.

As questões tratadas neste tema, Religiosidade/Espiritualidade, expressam como mães e pais encontram a força para suportar conjuntamente a realidade do momento em que vivem, na qual o apoio é importante, assunto seguinte a ser tratado.

\subsection{APOIO}

O tema Apoio foi composto fundamentando-se nos subtemas: Apoio e Relacionamento familiar, que estão imbricados e reportam-se à esfera das relações familiares, envolvendo a interação entre pai, mãe e filho, reafirmando a família como fonte de apoio e como uma unidade primária de cuidado, também comporta o apoio de outras pessoas e instâncias, sendo essencial no decorrer do período de indefinição do diagnóstico.

Sabe-se que as pessoas portadoras do HIV/Aids enfrentam muitos desafios, essa questão é muito mais do que um evento biológico, tornando-se, às vezes, secundário diante das situações sociais que decorrem desse fato (Castanha et al., 2007).

Essa realidade envereda para a busca de apoio, incorporada nos laços sociais, expressão que encampa dois conceitos, o de rede social e apoio social, englobando as relações sociais que envolvem o indivíduo, bem como as características de disponibilidade e freqüência de contato com amigos e parentes, ou 
com os grupos de pessoas com quem há contato ou alguma forma de participação social, por exemplo, grupos religiosos e associações (Chor et al., 2001).

Os trechos de relatos apresentados abaixo ilustram esse tema:

Conversar ajuda bastante. A gente precisa conversar. (10B)

É importante porque se a gente não tiver um apoio familiar, a gente fica louca. (3A)

As necessidades de cada família são diferentes, dessa forma, conhecer a percepção do grau de vínculo entre o indivíduo e sua família poderá ser a chave para melhorar a assistência, é promover apoio, em diferentes níveis, aos membros da unidade familiar.

Estudo de Schuster et al. (2000) evidenciou que 28\% dos adultos vivendo com HIV nos EUA, dos quais $60 \%$ mulheres e $18 \%$ homens têm filhos com menos de 18 anos, o que exige o desempenho de seu papel de pais e mães, configurados na tarefa de criação, sustento e bem-estar dos filhos. Essa responsabilidade foi pautada num modelo de família nuclear, informação esta que foi popularizada por meio do Guia para Cuidadores da National Pediatric \& Family HIV Resource Center (2001).

Diante dessa realidade, enfocarei, prioritariamente, o relacionamento entre mães e pais, uma vez que a união dos parceiros se caracteriza pela aliança de objetivos, cooperação e amor, enquanto que a cumplicidade que os une por laços de confiança, presentes na relação conjugal, permite que dividam os infortúnios e também é uma maneira de diminuir seus medos, ansiedade e a sensação de isolamento, como constata-se nos relatos abaixo:

Um dá força para o outro, por mais que a gente tenha problemas, a gente tem apoio um com o outro. (2A)

O nosso apoio é com a gente mesmo. (12A)

Nós vamos passar por tudo isso e vamos vencer. Nosso dia-a-dia é normal como qualquer outro casal: é briga, é discussão, a gente se gosta, se ama, daqui a pouco, a gente está discutindo. (7A) 
Esse apoio mútuo é essencial, uma vez que a vulnerabilidade individual, o medo da morte, de causar mal ao filho ou perder o parceiro são riscos constantes, fatores que são acentuados na presença da aids, tendendo os portadores ao isolamento (Azevedo, Guilhem, 2005). Ao compartilhar a luta, transformam a jornada de espera pelo resultado do exame do filho em suporte, que é buscado entre os parceiros. O filho representa uma forma de estreitar os laços afetivos do casal, e enseja uma garantia de manutenção do vínculo conjugal (Barbosa, 2001), afirmação dita pelas mães:

A chegada dela foi uma bênção, foi uma bênção. (6B)

Que nem eu tô vendo essa imagem tão bonita, está o pai, a mãe e os filhos, tudo em paz. Eu gostaria que a minha... a minha família fosse assim, sabe? Entre eu, meu marido e meus filhos. (8B)

Somos um casal legal, temos briguinha, mas a gente está unido no propósito de ajudar ela até o final, vai dar certo, se Deus quiser. (4B)

Os depoimentos de mães e pais do estudo revelaram uma associação positiva no relacionamento familiar, tanto na constatação de uma melhora, como no desejo de manterem a família unida, superando as pressões do cotidiano, e mesmo as adversidades do casal no sentido de evitar atitudes tempestivas. Esse aspecto evidencia a importância das relações familiares na vivência da soropositividade, como se segue:

A minha gravura não é só o bebê, não é o bebê, é tudo... Eu estou a ponto de ai, jogar tudo pro alto, subir, gritar, espernear, muito mais... Eu tô muito cansada, cansada mesmo, a ponto... Mas, não faço pelos filhos, não faço nada de errado pelos filhos... (2B)

Nesse momento não sou eu, não importa eu, é o futuro deles, a felicidade são eles... Porque se eu fosse sozinha, acho que não estaria mais aqui, porque a vida é muito difícil, muito, muito... (2B)

Nós não estamos conseguindo no momento viver juntos, por diversas coisas, o gênio de cada um. Mas, o que eu sempre insisto, é que a gente não pode pensar só em nós. (2B) 
Os relatos dos pais e mães do estudo indicam nítida variação entre a percepção de receber e necessitar apoio. Sustentar-se em uma situação difícil requer auxílio, seja da família, dos amigos, seja de grupos comunitários, de profissionais envolvidos no processo e do Estado, e pode ser decisivo para os rumos que a situação tomará.

A gente precisa conversar, quando tem que ver o resultado de um exame meu: dá isso, dá aquilo, poxa, a cabeça a mil. Não sabe o que fala, o que acha, o que é. É difícil... Às vezes converso com a psicóloga, é um chororó também, aqui um pouquinho mais, é difícil. (10B)

Tem que melhorar mais, principalmente pra gente que tem esse tipo de problema... Mais emprego, mais ajuda que a gente não tem... ter mais ajuda do INSS, uma ajuda por fora, você já trabalhou muito, o que tem na carteira não conta. (11A)

O apoio social tem sido apresentado como fator que contribui para diminuir o estresse e favorecer os mecanismos de enfrentamento de indivíduos em diferentes condições crônicas de saúde, principalmente na vida dos portadores de HIV/Aids

Ao considerar que a família é a principal fonte de apoio para soropositivos, a necessidade de apoio estende-se para além do núcleo familiar, alcançando os amigos do casal, assim, ambos, família e amigos se constituem em expressivos fatores de proteção àqueles que precisam enfrentar a infecção, tanto a participação no tratamento, como fonte de apoio afetivo (Tunala, 2002; Simoni et al., 2000; Carvalho et al., 2007).

O problema torna-se mais profundo quando os indivíduos apresentam fragilidade ou mesmo ruptura de laços familiares, pois isso potencializa a sua suscetibilidade a doenças e torna-os vulneráveis. Pessoas abandonadas, isoladas, na percepção dos profissionais de saúde que os atendem, têm mais dificuldades de aderir ao serviço e à medicação (Paiva et al., 2002; Miranda, Teixeira, 2006).

A gente ficou muito unido sabe? Mas agora vamos ver, porque ele não mora mais comigo, ele me dá apoio, eu tô tranqüila. (5B) 
O apoio social se define como recursos postos à disposição por outras pessoas em situações de necessidade, como apoio emocional, que consiste em comportamentos de escutar, prover atenção ou fazer companhia. Pode ser medido por meio de percepção individual (Griep et al., 2005). Esse suporte contribui para as pessoas sentirem-se cuidadas, valorizadas, estimadas e seguras de que poderão contar com esse apoio, exemplificado pelos pais:

Ela (colega) descobriu, mas não comentou nada, somente com o namorado, (...) ele veio, me abraçou e falou que vai me ajudar... (12A)

A percepção do apoio recebido pode ser baseada na freqüência desse e à satisfação diante da disponibilidade de ajuda que auxilia a pessoa no manejo ou resolução de situações práticas ou operacionais do cotidiano, como apoio material, financeiro ou para as atividades diversas do dia-a-dia.

Os sistemas de suporte fazem parte de um âmbito mais amplo da vida das pessoas, igualmente são importantes, contribuindo para a saúde geral e para o bem-estar dos portadores de HIV/Aids. Trata-se das relações estabelecidas com a escola, o trabalho, centros religiosos ou instituições de saúde, papel das organizações governamentais e não-governamentais e a religiosidade. (Carvalho et al., 2007). Para exemplificar cito os seguintes relatos:

O pessoal da Igreja Católica está nos acompanhando, ajudando e incentivando bastante. (1A)

Mas aqui, graças a Deus, eu sou bem atendida, e isso ajuda até a gente superar a doença. Por você ser bem atendido, você tem coragem de lutar contra a doença. (11B)

Agradeço, tem um plano aí que dá o leite [...] Sorocaba, é uma cidade que dá apoio total. (7A)

Os relatos também foram explícitos ao demonstrar a importância das relações familiares na vivência da soropositividade. Na concepção de algumas mães e pais do estudo, o filho selou a união da família: 
A família se uniu, antes ele nem ligava quando ela estava pra rua, deixava, agora não... ele se preocupa mais, uniu a nossa família. (6B)

Também acreditam que serão felizes com o filho, como se pode constatar pelo relato:

É... eu ainda vou ser feliz com meus filhos. Ah! Vou... Com certeza vou... muito. Até Deus querer. (10B)

Diversamente no período compreendido entre as duas entrevistas, verificou-se que foi comum o contexto familiar ser alterado por abandono do pai, tornando a mãe provedora da família, embora com tentativa de superação, amparada na forte ligação afetiva com os filhos e com o bebê exposto. Outras mães já se encontravam como provedoras da família, devido ao parceiro estar cumprindo pena em regime fechado e internação, situação que causou queixas em relação à carência financeira, privando as mulheres, principalmente, de remédios e alimentação adequada e tornando-as dependentes de ajuda das redes de proteção/apoio, presentes na Igreja e nas ações do programa municipal.

Estou trabalhando em casa, não tem como ele ajudar, porque ele nunca trabalhou. (11A)

O pai dele não o viu mais, não deixo, agora estou só... pra comprar remédio e fralda, um monte de coisa pro moleque. (1B)

A realidade de vida das pessoas portadoras de HIV/Aids ressalta a valorização do apoio social, formado pelo enfrentamento cognitivo e aceitação da infecção, pela participação da família no tratamento e pela fonte de apoio afetivo, bem como das instituições, estas condições caracterizam-se como fatores de proteção que contribuem para a saúde e bem-estar dessas pessoas, aspecto que será detalhado a seguir. 


\subsection{PREOCUPAÇÃO COM A SAÚDE DO FILHO}

O tema Preocupação com a saúde do filho é composto pelos subtemas: Preocupação com a saúde do filho e Cuidado e tratamento, ambos englobam uma inquietação com as demandas do filho, principalmente com o tratamento, uma vez que os pais valorizam e confiam em sua eficácia, trazendo esperança para a "cura", isto proporciona conforto enquanto aguardam a "cura" da criança, além de minimizarem o próprio sofrimento motivado pela possibilidade de terem transmitido o vírus da aids ao filho. Pode-se constatar esta situação nos seguintes relatos:

É uma situação bem difícil, mas superável. Tenho um supercontrole sabe, não me desespero, se tem que tomar remédio eu tomo, se tem que dar medicação pra ele, eu dou em dia, hora certa, sempre aguardando na esperança que ele seja negativado, se Deus quiser. (11B)

Pergunta todo dia, se dei o remédio certinho, se dei água, se ela tomou banho, se preocupa. (6B)

É o que mais quero que aconteça, superfeliz, tomara que logo esteja negativo de verdade. (12B)

Nos depoimentos das mães e pais, além de acreditarem na não confirmação do diagnóstico do filho para o HIV, emergiu também a vontade de acompanharem o seu crescimento, como ratificam:

Eu sempre penso em ver ela grande, brincando. Penso positivo, nunca pensei negativo e quero que ela cresça bem. Se ela tiver o HIV ou não, e se negativar ou não, do mesmo jeito nós vamos continuar amando ela.

Dessa forma chama a atenção que as mães adotam uma mudança de atitude no cuidado com a saúde do filho, há uma crença de que é preciso cuidar com mais atenção, que pode ser ratificado: 
A gente mudou, já é outro cuidado, banho tem que ser bem na hora do sol quente, aumenta mais o cuidado da gente. (5B)

O cuidado vai ser sempre em dobro, como se fosse uma criança especial, tem que estar mais atento. (6B)

É o desespero que a gente fica, quando a criança adoece, a gente tem mais cuidado, pensa que por causa do problema, qualquer coisinha vai prejudicar. (6B)

Nesse contexto, ter um filho exposto representa uma intensificação na responsabilidade do cuidado de sua saúde. Acreditam na soronegatividade do bebê pela efetividade do tratamento (Moura, 2002; Pedro, Stobäus, 2003).

Como mãe, a mulher utiliza-se de todos os recursos disponíveis para cumprir seu papel de protetora, de justificar a opção pela profilaxia. Neste sentido, o cuidado dedicado aos filhos exige um investimento significativo de tempo e recursos, e também dispêndio de energia dos pais, especialmente, das mães, como ilustram os relatos:

A gente faz tudo por um filho, acorda de madrugada pra dar o remédio certinho, né? Se a gente não cuida deles, quem vai cuidar? (3A)

Não adianta só gerar um filho, tem que dar segurança, a alegria, é atenção, até o resto da vida, até um dos dois, quando Deus quiser levar. (2B)

Esta dedicação está associada, tanto a aspectos subjetivos como sociais e culturais do ser mulher e mãe. A aids entre mulheres tem um impacto social maior do que em outros segmentos da população, uma vez que estas, nos dias de hoje, ainda assumem culturalmente o papel de "agregadoras e cuidadoras" dos núcleos familiares (Barroso et al., 2006). Exemplifico esta situação com o relato de um pai que aponta a dificuldade do homem cuidar do filho: 
Quando a mãe morre e o pai fica, a dificuldade é tão grande pra ele cuidar, criar, essas coisas... Do que o contrário, o pai morrer e a mãe ficar, a segurança total vem da mãe. O pai tem as suas obrigações $e$ deveres, mas só que a segurança faz, parte da mãe, se a mãe não se sentir bem, a criança não vai ficar bem. (2B)

Embora o tratamento esteja disponível na clínica municipal de DST/Aids, configurados no acesso às consultas pediátricas e aos exames laboratoriais, ao fornecimento da fórmula infantil e de medicamentos, há dificuldades que limitam sua operacionalização. Realizar estes procedimentos transcende o cumprimento de horário e dose prescrita, implica também em adotar estratégias para manter em sigilo, bem como fazer o acompanhamento clínico, como contam as mães e pais:

É difícil. Você tem que sair e esconder o remédio, isso aquilo, é duro, entendeu? Ela não toma, mas eu tomo. Já tomou o AZT, ela vai pegar esse medicamento agora (Bactrim), ela achava que aquele remédio era xarope... (6A)

Eu faltava só quando vinha na clínica. Esse é o problema, porque a gente tem muito exame pra fazer, pegar remédio. (11A)

A impossibilidade de amamentar apareceu nos relatos como um dilema e foi uma experiência penosa e emocionalmente desgastante; a mãe lamenta que:

A espera é muito dolorosa, a maternidade é bonita, mas nesta situação.. Queria ter filho normal, pegar e dar de mamar pro meus filhos no peito, coisa que eu fiz com os outros... (10B)

As mulheres se entristecem pela negação do seio materno, mas compreendem a importância de não amamentar convivendo com a incerteza do futuro, para si e para seus filhos (Silva I, 2005). Na condição de gestantes e puérperas já demonstram constrangimento com essa situação, tornando a maternidade incompleta, e isto acarreta culpa, frustrações, sofrimentos, desejos 
interrompidos, impotência e sonhos desfeitos. Contudo, algumas demonstraram indiferença diante do fato, corroborados pelos estudos de Paiva, Galvão (2004); Athaniel (2006); Moreno, Rea, Filipe (2006); Thior et al. (2006).

Esse lamento por não poder amamentar o filho, é referido pelas mães como falta de atenção, pois a amamentação é valorizada como uma oportunidade de cuidado fundamental à criança, sendo essencial nas orientações dos profissionais de saúde e ressaltado no conhecimento geral da população sobre os benefícios do aleitamento materno.

Outro aspecto relaciona-se à possibilidade de questionamento, pelos parentes, pela não-amamentação, aliada ao fato de perder a prerrogativa da exclusividade na alimentação da criança, e ainda, alimentar por mamadeira diminui o contato físico e provoca sensação de culpa. (Rollins et al., 2004; Moreno, Rea, Filipe, 2006; Athaniel, 2006).

Eu tenho medo porque minha sogra não sabe. Inclusive quando eu não podia amamentar, o peito estava cheio, ela vivia perguntando: Por que você não dá de mamar? Tem leite. (6A)

Uma vez que a cobrança social é forte, as mães são postas em situações embaraçosas e procuram desculpas socialmente aceitas para justificar a não-amamentação.

A política nacional para a prevenção da transmissão materno-infantil do HIV estabelece ações de intervenções protetoras, tais como: Terapia AntiRetroviral (TARV), cesárea eletiva, e contra-indica à amamentação, medidas preventivas comprovadas. Diante dessa situação, várias estratégias têm sido recomendadas para minorar as dificuldades das mães soropositivas, com o intuito de promover e fortalecer o vínculo materno-infantil nesse contexto. Destaco as publicações do Ministério da Saúde do Brasil relacionadas ao tema: Guia prático de preparo de alimentos para crianças menores de 12 meses que não podem ser amamentadas e Manual normativo para profissionais de saúde de maternidades referência para mulheres que não podem amamentar, pautadas nas Recomendações para Profilaxia da Transmissão Vertical do HIV e Terapia Anti-Retroviral em Gestantes (Brasil, 2007c).

Estes manuais apresentam alternativas práticas para o cuidado do filho, 
durante os momentos de alimentação, do banho, enfim, a participação da mãe como cuidadora, possibilitando o crescimento e o desenvolvimento emocional adequado à criança.

Neste tema, Preocupação com a saúde do filho, um ponto ressaltado pelos depoimentos foi a tomada de consciência sobre a vivência da soropositividade, possibilitando uma re-significação e/ou a construção de novos caminhos diante da adversidade, adotando uma trajetória diferente para sua vida, como constatamos na fala do pai:

Interessante que depois que aconteceu isso comigo, até melhorei, criei responsabilidade, porque tenho medo da vida, antes eu não dava valor a vida, não tava nem aí. (12A)

Essa mudança de comportamento pode ser configurada como resiliência, assunto tratado em estudos de Sória et al. (2006) e Carvalho et al. (2007), que ao buscar compreender os possíveis fatores de proteção no enfrentamento da infecção pelo HIV/Aids, fazem uma ampla abordagem do tema, o qual é entendido como uma "reafirmação da capacidade humana de superar adversidades e situações potencialmente traumáticas", não sendo uma característica do indivíduo, mas a interação dinâmica existente entre as características individuais e a complexidade do contexto social, em suma, é a relação dos fatores de risco com os de proteção, ancorados num processo.

O amor ao filho consegue mobilizar o desejo de mães-pais em mudar a forma de viver, possibilitando uma conexão positiva que envolve costumes e hábitos, ultrapassando dificuldades severas e proporcionando uma alternativa de agregação.

Espero que eu consiga um emprego, entendeu? Que eu pare com meus vícios e que nada falte pra minha filha, poder dar tudo pra ela. (3B)

A vivência da maternidade e da soropositividade suscita Preocupação com a saúde do filho e desperta temores relacionados ao preconceito, tema que será abordado na seqüência. 


\subsection{PRECONCEITO}

O tema Preconceito, composto pelos subtemas: Preconceito $e$ Soropositividade, trata do aspecto mais característico inerente à gênese da aids, situação que atravessou mais de duas décadas, e, apesar dos esforços para combatê-la, ainda é forte sua presença. O impacto da soropositividade na vida de homens e mulheres é marcado pelo estigma, que está fortemente associado ao medo do contágio que permeia as doenças transmissíveis, determina o preconceito e a discriminação, e também afeta a psiquê dos homens e mulheres, devido ao medo e à insegurança gerados pela possibilidade da finitude existencial.

A experiência profissional mostra que a sociedade ainda discrimina e contribui para as dificuldades sociais dos portadores. Ao vincular o HIV a drogas, à promiscuidade, ao homossexualismo e à traição conjugal, traz à tona o mais íntimo das pessoas, escondido por meio de tabus. O preconceito sofrido pelos indivíduos portadores do HIV, muitas vezes considerado o pior da doença, pode levar a atitudes de discriminação verificadas pelo afastamento do grupo social do doente e, por sua vez, o doente do seu grupo social. (Ramos, Bagnato, 2002; Kern, 2003; Carr, Gramling, 2004; Ribeiro et al., 2005; Castanha et al., 2006; Almeida, Lambronici, 2007).

Os depoimentos de mães e pais deste estudo foram esclarecedores no ponto de vista do preconceito e estigma, tanto por sofrerem, como por temer sofrer o preconceito, do mesmo modo antevendo circunstâncias constrangedoras e desfavoráveis ao filho, como nos relatos:

A gente sente mais cuidado, proteger do mundo, bem dizer do preconceito das pessoas. Fica com mais cuidado com relação ao bebê, porque quer proteger. É difícil. (6A)

E quando souber que eu tenho? Como saber qual a reação deles?

Querer rejeitar por ela ter uma mãe assim... e ela poder ter nascido assim. (6B)

A pessoa estigmatizada carrega uma identidade marcada e deteriorada, 
associada à atribuição social de desvio que leva ao descrédito, situação que enseja uma atenção especial dada às repercussões da discriminação e do preconceito no contexto do HIV/Aids. Este fato tem sido amplamente discutido em razão das inúmeras dimensões que acometem os indivíduos. Muitos estudos são norteados pelo conceito de estigma de Goffmann (1988), que define estigma como um atributo que tem um significado depreciativo de quem o porta e que a sociedade utiliza-o para desqualificar a pessoa, uma vez que tal atributo é entendido como defeito, fraqueza ou desaprovação. O relato a seguir é um exemplo:

A gente tem que ter mais auxílio. Ter essa doença é complicado... Você vai contar pra alguém? Só discriminação... Vai ter só discriminação... (11A)

Percebe-se neste relato o sentimento próprio de sofrimento, causado pelos constrangimentos impostos não pela dor infringida ao corpo doente (ser ou não ser doente de aids), mas pelo intenso preconceito e discriminação determinado pelo meio externo. O sentimento de culpa, que reflete a discriminação em torno da aids, aparece como castigo pelo comportamento divergente dos valores morais da sociedade (Almeida, Lambronici, 2007).

Os relatos deste estudo permitiram constatar que a discriminação é proveniente de diferentes contextos, vindos da sociedade e da família, que dificultaram o enfrentamento da infecção e a recomposição da vida dos infectados, como afirmam os participantes desta pesquisa:

Na minha família ninguém sabe, espero que ninguém fique sabendo, minha família é do Norte e não vai entender, eles acham que já está à beira da morte, como eu já tenho dois filhos, ela não vai querer misturar, minha mãe é muito preconceituosa ... (11B)

Eu tento me esconder o máximo quando vou na clínica... Se chegar na boca do patrão, pode querer dispensar a gente. (12A)

A discriminação é baseada e movida pelo estigma. $\mathrm{O}$ preconceito pode ser consciente ou inconsciente, dirigido para pessoas, grupos ou classes sociais (Silveira, Carvalho, 2003). Tem-se tentado entender discriminação e estigmatização 
como um processo social, transformando diferenças em desigualdade: desigualdade de classe, de gênero, de idade, de raça ou etnia, de sexualidade ou de orientação sexual.

Mulheres portadoras de HIV/Aids têm mencionado que temem e vivenciam o preconceito. Dentre muitos problemas relacionados a esse fato, pode surgir a dificuldade de colocação profissional, além dos problemas familiares e daqueles ligados à maternidade (Simoni et al., 2000; Kern, 2003; Carr, Gramling, 2004; Barroso et al., 2005; Carvalho, Piccinini, 2006). Todos esses aspectos constituem o que vem sendo descrito como a morte civil e social dos soropositivos, ela é produzida pela sociedade ao limitar os direitos dos indivíduos.

\footnotetext{
Você leva o atestado da clínica, eu fui mandada embora exatamente por causa desse problema, eu trabalhava de empregada doméstica e levei o atestado da clínica de DST e na outra semana ela me mandou embora, não falou o motivo. (11A)
}

Inúmeros estudos dão conta dessa realidade, o estigma sustenta um conceito importante da epidemia. Em artigo, Lynne (2005) examinou o significando de estigma na literatura e apresenta um estudo etnográfico realizado em área rural de alta-prevalência no Zimbábue, África, revelando como o estigma, sofrimento, vergonha e silêncio desafiam os esforços de promoção de saúde.

O preconceito esteve presente nos depoimentos deste estudo, causando agruras, contratempos e transtornos, que se manifestaram nas dificuldades para a realização de ações para o acompanhamento e o tratamento da criança, principalmente, para os pais que trabalhavam. Estas dificuldades foram expressas pelos freqüentes retornos à clínica, e pelo temor de encontrar pessoas conhecidas que até então ignoravam sua condição de portador. Tal situação se converte em rotina em suas vidas. Vê-se esta condição nos relatos a seguir.

Então, fica difícil você faltar do serviço porque tem sempre exame, tem que sempre estar vindo aqui na clínica, como vai justificar tanta falta? (11A)

É complicado, o que está sendo mais complicado é esta parte. Esconder, sempre esconder... É complicado até da gente falar sobre isso. É difícil conversar sobre isso. (6A) 
A percepção de não poder contar com o apoio da família expõe o medo e a força do estigma e do preconceito que são vítimas. Ao ressaltar os problemas sociais e afetivos ligados à doença, faz com que os portadores evitem revelar o diagnóstico a familiares.

O pessoal do Norte não entende como que é isso, acha que passa no conversar, é muito complicado explicar a situação, eu prefiro ficar só pra mim, uma coisa que é só minha. (11B)

Essa situação pode ser um obstáculo ao processo de enfrentamento, prejudicando um dos fatores de proteção identificados como promotor de resiliência em pessoas que vivem com HIV/Aids, sobrevindo nos indivíduos crenças de que, se revelarem seu diagnóstico, não serão mais aceitos pela família, que serão abandonados e motivo de vergonha para seus familiares (Carr, Gramling, 2004; Carvalho et al., 2007).

A estigmatização é tão grande que estimula a negação e o segredo que reforça o silêncio, esta situação é delicada para mães e pais da criança exposta, que vão desde resguardar o seu diagnóstico, encontrar motivos que justifiquem as constantes idas à clínica para o acompanhamento e tratamento, e mesmo para buscar estratégias para camuflar o local de tratamento:

Eu fiz esse casal porque a gente vive um casal normal, um casal perfeito, sossegado, a gente não pensa no HIV. (5A)

Eu passo ele aqui na clínica, mas falo que tô indo na Santa Casa e assim vai indo... (11B)

O preconceito é grande, enorme... Eu não falo pra ninguém que eu tenho, porque se eu falar eu sei que tem preconceito, então, eu não comento. (11B)

Ferreira (2007) verificou que as mulheres infectadas pelo HIV/Aids revelam a sua condição de soropositividade à família e amigos quando há identificação com outro soropositivo, por pressão ou confiança, busca de apoio e preocupação com possível transmissão do vírus ao parceiro, pautadas em 
experiências positivas de apoio ou quando não conseguem mentir quando questionadas. Por outro lado, mantêm segredo em situação de medo do preconceito, de se exporem ou se houve experiências negativas como falta de apoio, rejeição e disseminação da informação, estabelecendo um pacto de silêncio, pois há temor de mudanças, envolvendo os filhos menores em relação à idade.

Por outro ponto de vista, alguns pais encaram com indiferença a soropositividade, demonstrando despreocupação com sua revelação e evitando pensar no HIV, enfatizado nos relatos:

Meu dia-a-dia é normal, eu não fico ligando, que os outros fiquem sabendo. Na clínica eu já encontrei a sogra da minha prima e ela saiu contando... Eu pedi pra não contar, porque ninguém sabia e mesmo assim saiu falando, mas não devo nada pra ninguém, ninguém vem na minha casa perguntar se está faltando alguma coisa. Quem paga as minhas contas sou eu. (12A)

Minha preocupação maior é essa [criar os filhos], quanto à doença não tenho preocupação nenhuma... (7B)

Para a redução das taxas de morbi-mortalidade em HIV/Aids há necessidade de se entender e agir, diante desse panorama contextual marcado pelo estigma, com compromisso político e social para aumentar ambientes encorajadores e reduzir o sofrimento do soropositivo, assim, reforça-se a importância dos sistemas de apoio para auxiliarem na dissolução do preconceito e da discriminação.

\subsection{FAZENDO ANALOGIA}

O tema Fazendo analogia aparece isolado, representa um recurso que foi usado pelos pais para interpretarem sua montagem, e que empregaram para relacionar as imagens escolhidas na dinâmica, pois estabeleceram semelhanças entre essas e o significado que as mães e pais atribuíram ao período de indefinição do diagnóstico do filho. 
Por esta capacidade de instaurar um princípio de identidade entre coisas que, genericamente, são desiguais, a analogia aproxima-se de figuras como a alegoria, a comparação e a metáfora (Ceia, [200?]). Interpretar significa construir, por meio de um sistema de signos (texto/obra), alguma coisa maior do que a presença física deste mesmo sistema (Tapajós, 2002).

Uma analogia procede sempre por identificação das semelhanças entre dois objetos genericamente diferentes, que pode estabelecer uma conexão. Esta equivalência permitiu a explicação e o sentido que mães e pais atribuíram ao período de indefinição do diagnóstico do filho.

Mediante essa transferência de significado, buscaram afinidade com as gravuras e expressaram nas narrativas o entendimento:

Aqui ele voando, eu acho que meu filho vai ser livre, vai se livrar disso, vai viver, vai conseguir... (10A)

Olhando a rosa, mostra que a vida é uma beleza, só que tem espinhos, a vida tem os espinhos, mas lá em cima após passar pelos espinhos tem um código, tem uma coisa bonita. (7A)

Essa montagem aí significa que a tartaruguinha está presa, ela está esperando ter a liberdade, poder ser solta, ter liberdade. Assim é meu filho... Esperando ele fazer os exames e ter resultado positivo, pra ele poder ficar livre disso aí. Esperando a liberdade, para poder seguir em frente. $(5 \mathrm{~A})$

Vale esclarecer que o tema Fazendo analogia não foi expressivo nas narrativas do estudo. Foi recurso empregado por três duplas mães-pais como meio para contarem sua experiência durante o período de espera do diagnóstico definitivo do filho. 


\section{IDENTIFICANDO O TEMA CENTRAL}

Ao concluir o tratamento e a compreensão dos dados obtidos, constatei que a relação entre os temas e seus subtemas demonstrou que estão fortemente inter-relacionados e que para mostrarem a vivência do binômio mãe-pai que aguarda a definição do diagnóstico do filho exposto, seria necessário a complementação da Figura 9 (apresentada anteriormente).

Diante dessa constatação, inclui no cotidiano da vivência do binômio mãe-pai o fator Enfrentamento, que emergiu como Tema Central deste estudo, pois perpassa cada subtema e por consequiência todos os temas.

A seguir, discorro brevemente sobre o significado de "Enfrentamento" e apresento sua inserção no diagrama representativo da VIVÊNCIA do binômio mãe-pai.

O tema central Enfrentamento pode ser definido como

esforços cognitivos e comportamentais, utilizados pelos indivíduos com o objetivo de lidar com demandas específicas, internas ou externas, que surgem em situações de estresse e são avaliadas como sobrecarga aos recursos pessoais (Lazarus, Folkman, 1984, p.141).

Esta definição decorre de estudos realizados sobre os efeitos do estresse no processo saúde-doença, ancorados na relação entre estresse e enfrentamento mediante interação entre o organismo e seu ambiente.

Outras denominações freqüentemente utilizadas são coping e resiliência, caracterizando as diversas formas de enfrentamento ao estresse. 
Antoniazzi, Dell'Aglio, Bandeira (1998), em artigo de revisão teórica, descreveram a evolução conceitual e apresentaram dois modelos de coping de Lazarus e Folkman, e de Rudolph, Denning e Weisz salientando suas diferentes posições teóricas e metodológicas. Por sua vez, Carvalho et al. (2007) apresentaram a abordagem sobre o conceito de resiliência como o potencial saudável que alguns indivíduos apresentam em situações de possibilidade de doença e indagando a influência na adesão ao tratamento e qualidade de vida dos portadores de HIV/Aids.

Outras publicações exemplificam a ênfase dada pelos pesquisadores, principalmente envolvendo a área da saúde, especificamente ligados a doenças crônicas e que trabalham com populações em situações de risco, vítimas de violência, crianças e adolescentes em situação de rua, soropositivos (Rose, Clark-Alexander, 1996; Simoni et al., 2000; Seidl, Tróccoli, Zannon, 2001; Prado et al., 2004; Seidl, Zannon, Tróccoli, 2005; Faria, Seidl, 2005; Paludo, Koller, 2005; Seidl, 2005; Seidl et al., 2005; Castro, Moreno-Jimenez, 2007), mas também encontram-se estudos em outras esferas do conhecimento, tais como o de Job (2000), Job (2003), Yunes (2003) e Pesce et al. (2004).

Deve-se destacar a importância da avaliação que a pessoa realiza sobre a situação ou evento estressor, quanto ao significado que tem para si, fato que influencia o processo de enfrentamento. Dessa forma, o que torna uma experiência estressante dependerá da interpretação de cada indivíduo, possibilitando percebê-la como dano, ameaça ou desafio. Nesta abordagem são analisados também os recursos disponíveis e a responsabilidade do indivíduo ao lidar com a situação.

As respostas a essa condição são pautadas pelo sistema de crenças predominante pela pressão gerada pelo problema, e pelas avaliações dos recursos disponíveis para enfrentá-los, enfim, considera-se que o enfrentamento é influenciado pela cultura, que modela as avaliações da situação e a visão de mundo dos indivíduos.

No modelo de Lazarus, Folkman (1984), que julgo pertinente para este estudo, a concepção de enfrentamento no modelo interativo do estresse envolve quatro conceitos principais: (a) é um processo ou uma interação que se dá entre o indivíduo e o ambiente; (b) sua função é de administração da situação estressora, ao invés de controle ou domínio da mesma; (c) os processos de enfrentamento pressupõem a noção de avaliação, ou seja, como o fenômeno é percebido, 
interpretado e cognitivamente representado na mente do indivíduo; (d) o processo de enfrentamento constitui-se em uma mobilização de esforço, por meio da qual os indivíduos irão empreender esforços cognitivos e comportamentais para administrar (reduzir, minimizar ou tolerar) as demandas internas ou externas que surgem da sua interação com o ambiente.

Nessa perspectiva, considera-se que a resposta ao enfrentamento é uma ação intencional, física ou mental, iniciada em resposta a um estressor percebido, dirigida para circunstâncias externas ou estados internos. Essas respostas justamente com as estratégias de Enfrentamento têm sido classificadas quanto à função em duas categorias: enfrentamento focalizado no problema e enfrentamento focalizado na emoção. No primeiro caso, a pessoa engaja-se no manejo ou modificação do problema ou situação causadora de estresse, visando a controlar ou a lidar com a ameaça, o dano ou o desafio; são, em geral, estratégias ativas de aproximação em relação ao estressor, como solução de problemas e planejamento.

O enfrentamento focalizado na emoção teria como função principal a regulação da resposta emocional causada pelo problema/estressor com o qual a pessoa se defronta, podendo representar atitudes de afastamento ou paliativas em relação à fonte de estresse, como negação ou esquiva (Seidl, Tróccoli, Zannon, 2001; Inouye, Flannelly L, Flannelly K, 2001). Ambas são usadas durante praticamente todos os episódios estressantes. O emprego de uma ou de outra pode variar em eficácia, dependendo dos diferentes tipos de estressores envolvidos.

Recentemente, foi apresentada uma terceira estratégia de enfrentamento focalizada nas relações interpessoais, na qual o sujeito busca apoio nas pessoas do seu círculo social para a resolução da situação estressante.

O manejo de enfermidades e agravos à saúde requer das pessoas o desenvolvimento de algumas tarefas adaptativas para o seu enfrentamento, como lidar com as consequiências fisiológicas da doença (dor, sintomas, incapacidades), do tratamento e do ambiente hospitalar; criar e manter boas relações com a equipe de saúde, família e amigos; manter o equilíbrio emocional e o senso de auto-estima e preparar-se para futuras exigências (Faria, Seidl, 2005; Seidl et al., 2005).

Autores que concebem enfrentamento como respostas a eventos específicos reconhecem, no entanto, que determinadas estratégias de enfrentamento podem sofrer maior influência de características de personalidade, enquanto outras 
parecem sofrer maior influência de aspectos situacionais ou do contexto (Lazarus, Folkman, 1984).

As circunstâncias em que vivem os pais e mães deste estudo, impõemlhes sofrimento psíquico, para o qual é preciso buscar respostas de enfrentamento, amparados em aspectos que promovam a superação ou minimização de conflitos identificados no cotidiano, seja pela ansiedade, tristeza, seja pelo estigma, medo ou preocupação com a saúde do filho.

Por outro lado, essas dificuldades se tornam meios para suportar a situação, estimulando atitudes dos pais que fornecem condições para se adaptarem à nova realidade, para prepararem-se alicerçados nos sentimentos positivos para com o lactente exposto, e na rede de apoio, dentro e/ou fora da família, e no seu ambiente social, com destaque para a crença na fé religiosa. A articulação destas condições gera os fatores de proteção que contribuem para a saúde e o bem-estar dos portadores do HIV/Aids, no interior do núcleo familiar.

A seguir, apresento a Figura 10 que expressa graficamente a VIVÊNCIA da mãe e do pai do lactente que aguardam o diagnóstico do filho exposto ao HIV, atendidos no Projeto Transmissão Vertical Zero de Sorocaba, SP.

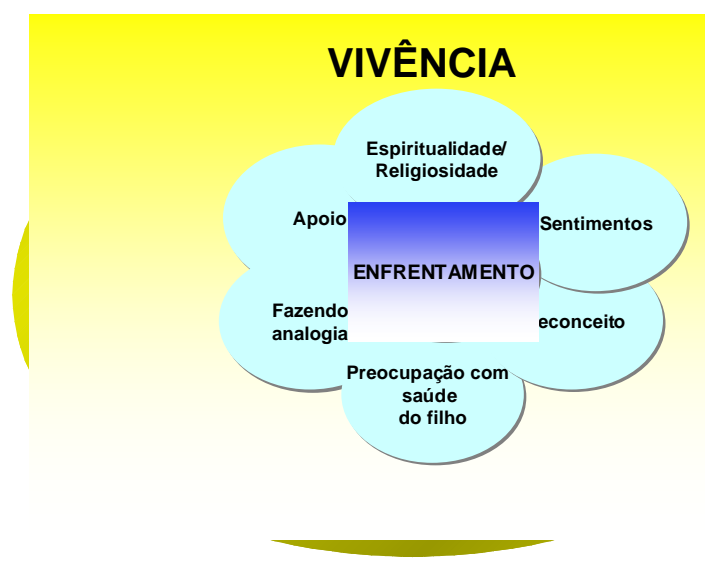

Figura 10 - Diagrama ilustrativo da Vivência de mães e pais

Com a identificação do Tema Central deste estudo, a seguir discorro sobre os aspectos culturais, segundo referencial adotado. 


\section{CONSIDERANDO OS ASPECTOS CULTURAIS}

Ao processar a análise dos dados obtidos neste estudo, foi possível associá-los e realizar uma integração, que conduziu à visão sobre a totalidade das experiências vividas por pais e mães em um contexto temporal e espacial, conhecendo os aspectos significativos apresentados, os quais foram assimilados e construídos ante a soropositividade para o HIV, são, portanto, específicos à vida do casal que aguarda a definição do diagnóstico para o HIV do filho exposto.

Foi possível captar a maneira pela qual estes pais pensam e reagem em face do período estudado, também possibilitou a apreensão dos sentimentos, dos valores, das atitudes e dos seus temores, enfim, os comportamentos das mães e pais no seu cotidiano de enfrentamento à aids.

O referencial teórico adotado para este estudo foi a Antropologia Médica, segundo Hellman (2003), que trata a doença como elemento cultural, reconhece-a como uma disciplina biocultural, a qual integra a ciência médica e a biologia com as ciências sociais e comportamentais, dimensão que permite a compreensão do fenômeno saúde-doença, pautado no conceito que o agir humano é norteado culturalmente.

De acordo com este referencial, a aids apresenta expressivas peculiaridades, tornando-a nitidamente um fenômeno biológico e sociocultural ao mesmo tempo, ao ponto de ser configurada como ameaça à saúde mundial, dada a sua abrangência tanto geográfica, quanto a sua disseminação vinculada a certos padrões de comportamento humano, principalmente, o sexual, além de provocar 
sofrimentos aos indivíduos afetados e as suas famílias, provoca também impacto econômico e nos valores da sociedade.

Os significados culturais apreendidos desse grupo de pais e mães, que vivenciam esse período de indefinição do diagnóstico do filho exposto ao HIV, proporcionaram o entendimento do modo como eles enfrentam essa trajetória, mediante os sentimentos expressados e as ações tomadas, e são subsídios para explicar a construção de estratégias de enfrentamento a esse período de incertezas, necessitando encarar os conflitos advindos e gerar respostas.

A relação entre os fatores de estresse e a reação a eles é complexa, e geralmente estão envolvidas mudanças ou eventos importantes na vida, podendo ser tanto positivas quanto negativas, essa definição é mediada pela percepção da pessoa, assim, alguns fatores podem ser estressantes para alguns e para outros, representar um estímulo para o seu enfrentamento; concorre para essa reação o contexto sócioeconômico e cultural em que vivem os pais, bem como suas características físicas e psicológicas.

$\mathrm{O}$ enfrentamento à situação da soropositividade para o HIV deste grupo foi sendo construído na experiência positiva com a gestação e o nascimento do filho, estabelecendo por si só uma mudança de estilo de vida, pois houve necessidade de mães e pais se adaptarem às circunstâncias do novo integrante da família. Para algumas mulheres representou uma mudança de posição social ao tornarem-se mães pela primeira vez.

O período de espera pelo diagnóstico definitivo do filho foi marcado por intensa mobilização de sentimentos, caracterizados pela ambigüidade, oscilando entre amor e sofrimento, esperança e ansiedade, preocupação com a saúde da criança e crença no tratamento, o que indica que usam o enfrentamento focalizado na emoção, ou seja, ajustam-se à situação, administrando a fonte de estresse da forma que lhes é possível, por meio de ações paliativas minimizando os efeitos estressantes, pois não há como mudar a condição de soropositivos.

O contexto da aids é relativizado em seu cotidiano em função da alteração na dinâmica familiar com a chegada do bebê, assim, o amor e os cuidados dedicados ao bebê se sobrepõem às preocupações com a própria infecção, permanecendo latente, e vindo à tona em alguns momentos como relatado por algumas mães, que só lembram da doença quando medicam a criança, ou que 
procuram manter a aids bem distante dos problemas familiares, uma vez que enfatizam a preocupação com a criação dos filhos.

A espera pelo resultado de cada exame laboratorial do lactente mostrou-se angustiante, mas, no próprio cotidiano, o binômio mãe-pai encontra forças que o impulsionam e o encorajam a continuar a vida, amparado no significado que atribui à maternidade, que determina e estimula a criação do filho, compreendido nos cuidados dispensados à criança, que são estabelecidos e refeitos diariamente nos laços afetivos e familiares.

Dessa forma, é nesta adversidade, que se criam, paulatinamente, pequenas, mas importantes estratégias de "sobrevivência", alicerçadas nos aspectos emocionais desencadeados pela forte ligação com o filho, o que assegura aos pais a esperança e confiança de que essa situação é superável e que, ao final, obterão resultado favorável.

O principal sustentáculo do enfrentamento é representado pela fé religiosa e na crença em um Ser superior. Essa fé surge como um recurso interno que se torna fonte de fortalecimento para as mães e pais, proporcionando-lhe segurança, mesmo para aqueles que não declararam freqüentar igrejas, ou mesmo não seguirem nenhuma religião, todavia manifestaram possuir espiritualidade, valorizando o significado e a razão de viver. A fé e a crença em princípios religiosos são reconfortantes, visto que favorecem a aceitação da infecção pelo vírus da aids, e proporcionam o engajamento no esforço de manter-se com saúde. É uma forma de minimizar os sentimentos dolorosos, acolhendo e tranqüilizando, enfim trazendo alívio para o sofrimento.

A maioria das práticas religiosas mencionadas pelas mães e pais relaciona-se à Igreja Católica, não só como batizado, procissão, romaria e orações, como, a menção a Deus que foi preponderante e descrita como símbolo de fé. Além desse suporte espiritual, a Igreja também é vista como fonte de apoio social, incluindo ajuda material e apoio emocional.

Outro aspecto relacionado à religiosidade refere-se à busca pela cura. Este pensamento articula Deus como agente, como força que proporciona aos médicos a cura, porém, está condicionada à vontade de Deus, que interfere no avanço da Ciência para produzi-la.

Embora as mães e pais demonstrem fé religiosa que favorece o 
resultado positivo para o diagnóstico do filho, ou seja, o filho será "negativado", o que significa não estar infectado pelo HIV, ambos são categóricos ao dizer que acreditam no tratamento, portanto, o valorizam, e adotam as medidas terapêuticas recomendadas, reconhecendo a importância da ação dos medicamentos e do acompanhamento pelo serviço de saúde. Entretanto, realizar o tratamento apresentou dificuldades, em virtude dos pais e mães desejarem manter em segredo a sua condição, isso os leva a esconder não só o medicamento, como o local onde são atendidos. Outro fator de estresse são as inúmeras idas à clínica para acompanhamento não só do tratamento do próprio filho como dos seu.

O grupo de mães e pais informantes não atribuiu ao destino o infortúnio gerado pela infecção pelo HIV, pois para eles, a origem da aids está no próprio indivíduo, algumas vezes, a doença está relacionada ao seu comportamento de vida, recaindo a responsabilidade sobre os próprios pais, principalmente, sobre a mãe.

Essa responsabilidade alcança a questão da vulnerabilidade da mãe, pois o adoecimento mostrou-se como preocupação de algumas delas, uma vez que sua ausência na família afeta o filho mais do que a falta do pai.

Conseqüentemente, as mães do estudo avaliam sua condição diante da soropositividade ao HIV, com base, também, na visão do mundo ocidental, no qual a saúde é determinada por ações pessoais, assentada na adoção de hábitos saudáveis e em comportamentos socialmente aceitos, que, quando não atendidos, a vítima deve sentir-se culpada por tê-los provocado, portanto, ser soropositivo ao vírus da aids é duplamente estigmatizante, não só pela sociedade que a condena como por se sentir culpada pela possibilidade de transmissão ao filho.

Para o conjunto das mães e pais, a preocupação com a saúde do filho envolve, além da transmissão, um cuidado especial, pois acreditam que a criança está fragilizada, associada aos fatores causadores de enfermidades, principalmente quando atribuem significado ao meio ambiente natural, como ventos, "dar banho na hora do sol bem quente", evitar resfriamentos. Tais circunstâncias provocam um estado de atenção redobrada pelos pais, pois qualquer intercorrência que a criança apresente ocasiona apreensão na mãe, pois ela faz associações com os sintomas da aids.

Como nas famílias saudáveis, estes pais e mães desejam os filhos com 
saúde, tanto em relação às condições físicas e econômicas, quanto investem para prover um ambiente familiar propício, tentando alterar hábitos e adotando atitudes propositivas para manter a família unida.

Um quadro que emergiu das narrativas dos pais e mães revelou os papéis determinados para homens e mulheres, o valor atribuído às mães. A criação dos filhos é tarefa essencial da mãe e caracteriza-se como fundamental para o desenvolvimento da criança. Para os binômios mãe-pai pesquisados, a segurança completa do filho reside na mãe. Ainda que o pai tenha obrigações e deveres de prover recursos para o núcleo familiar, a associação dessas funções, ao que foi exposto anteriormente, reforça a concepção de gênero presente neste grupo, que, no entanto, não dispensou algumas mães de assumirem a manutenção das despesas domésticas e dos encargos para a criação dos filhos, em razão do parceiro encontrarse encarcerado, doente ou ter abandonado o lar.

Para o enfrentamento desse período, são poucas as mães que recorrem ao apoio de familiares, em busca de amparo e conforto, outras contam somente com as instituições de saúde e religiosas. Alegam que seus familiares são "ignorantes" e acreditam que eles agem com discriminação. Fato interessante a ser destacado é a visão de que parentes que vivem na Região Norte do país vêem a aids relacionada à morte.

De uma maneira geral, para este grupo, o apoio e o relacionamento familiar têm grande valor, porque os aspectos psicossociais, compreendidos nas relações humanas e afetivas, têm um predomínio e atuam como fatores de proteção promotores de resiliência, ainda que para isto concorram as características individuais, a rede de apoio social e afetiva. A principal força ocorre na família nuclear, os laços afetivos com o filho e o parceiro constituíam-se, também, em um fator de aproximação e união da família, ao harmonizar as relações/satisfação com a chegada do bebê.

Há pontos que facilitam esse enfrentamento, entre os pais e mães que vivem numa condição de estabilidade emocional, pode servir como estratégia para evitar as situações de discriminação e os processos de estigmatização. É um modo de manter o segredo e a privacidade, sem estabelecer conflitos abertos. Este equilíbrio pode tornar-se saudável na aceitação da infecção, portanto, contribui para minimizar o sofrimento e superar as dificuldades acarretadas pela doença. 
Por ser uma doença especialmente urbana, o acesso aos serviços de saúde e ao tratamento são favorecidos, particularmente, porque as cidades detêm maior concentração de recursos médicos e uma estrutura de apoio social melhor provida, tanto no âmbito governamental, como na rede de apoio social, configurada por ações de grupos religiosos ou simpatizantes à causa.

Ao abordar a aids, depara-se com a perspectiva popular de uma doença grave, difícil de tratar e controlar. É a doença predominante na contemporaneidade e predispõe a criação de uma variedade de imagens, como a metáfora e temas culturais, que procuram fornecer respostas a perguntas geradas pelo assombro das pessoas diante da epidemia. As enfermidades com essas características tornam-se metáforas, pois para explicar o seu aparecimento fazem associações simbólicas no sentido de se apropriarem desse conhecimento.

As metáforas em uma cultura são formas novas de ver e vivenciar o mundo em que as pessoas vivem. Desempenham papel importante na definição da identidade do indivíduo e do outro; na imaginação das pessoas, há crenças tradicionais sobre a natureza moral da saúde, da enfermidade e do sofrimento humano, às vezes são caracterizados como moralmente errados.

As metáforas não são apenas fenômenos de linguagem para explicar as enfermidades, mas também são incorporadas e internalizadas por aqueles que as empregam. O problema que geram reside no impedimento de avaliações racionais dos riscos da doença e de como ela é reconhecida, controlada, prevenida e tratada.

Tais considerações coincidem com os significados apresentados pelos colaboradores deste estudo, os pais e mães utilizaram esse recurso para expressar os sentimentos, o significado dado ao período de espera, associando a imagem de liberdade para expressar a esperança depositada que o filho vai se desvencilhar da doença, vai se libertar do mal, que representa um empecilho à sua saúde. A certeza de que a criança se salvará não invalida a dúvida se o mesmo ocorrerá com os pais, uma vez que a aids é tida como manifestação da sua "imoralidade" por algum comportamento desviante; portanto, ser soropositivo para o vírus da aids sugere julgamentos morais, psicológicos e de caráter, do próprio doente, levando-o a reflexões sobre as suas falhas morais ao longo da vida.

Esta constatação gera sentimento de culpa, e esse sentimento é autêntico. O binômio mãe-pai acredita que será punido com o sofrimento, 
conseqüentemente carrega um fardo, um peso, que é exposto pelo inconformismo da mãe, ao afirmar que tem o vírus e ainda o passou para o filho. Essas noções, ligadas à idéia de punição moral atribuída à aids, têm levado as pessoas acometidas pela doença a se "ocultarem" do convívio social em virtude dessa "carga" moral.

Enquanto aguardam o diagnóstico definitivo da criança exposta ao HIV, a mãe e o pai deste lactente vivem um período de grande estresse psicológico, decorrente do estigma e preconceito, que são percebidos pelo binômio, para evitar a situação de discriminação, ou pressupor tal possibilidade com o filho, que envergonha e reforça a culpa dos pais, tal situação os impulsiona ao isolamento sociocultural. Evitar comparecer em locais públicos, temer a descoberta da doença, sofrer conseqüências na vida familiar e profissional, reforçam atitudes, como esconder os medicamentos utilizados para o tratamento, pedir a conhecidos que não contem a outras pessoas sobre a sua doença; enfim, o binômio tenta se precaver e não oferecer pistas para familiares, vizinhos ou para qualquer outro indivíduo que ignoram a soropositividade, pois, são fatores que acarretam incômodo na dinâmica do casal, especialmente o sorodiscordante.

A presença da aids e a reação que causa nas pessoas são, em grande parte, determinadas por fatores socioculturais. Ao se considerar que cada cultura tem representações próprias sobre gênero, classe social, religião ou família, que possui sua própria linguagem do sofrimento, mediada pelas experiências subjetivas de comprometimento do bem-estar e o reconhecimento social dessas experiências.

A privação foi outra condição encontrada dentre os pais e mães do estudo. Não poder participar livremente de algumas atividades traz sofrimento e desgaste emocional, representado pela não-amamentação e por procurar justificativas para realizar o acompanhamento no serviço de saúde, bem como contando com o apoio institucional e com benefícios para transporte gratuito. A discriminação diante de sua condição representa para as mães deste estudo, que são jovens, a sensação de atrair olhares quando são identificadas como doentes, porque o acesso gratuito ao transporte coletivo, é aceitável em idosos devido à aposentadoria, mas não para um jovem.

Tanto na constatação prática, quanto pela observação, as mães e pais sentem e sofrem preconceito, tendo repercussões diretas com o trabalho; podem, pois, ser demitidos ante a divulgação da condição sorológica no ambiente 
profissional.

O conhecimento popular sobre a aids, no tocante à disseminação e prevenção, ainda é permeado por crenças, identificadas nos relatos das mães e pais, que a descrevem como evidência de "sangue ruim"ou "sangue sujo", em oposição à imagem de "sangue limpo", ilustrando uma concepção cultural, na qual a criança exposta está com o sangue infectado e isto a torna impura, mas em razão da confiança e da fé em Deus, acreditam no resultado negativo dos exames para o HIV do filho, o que sugere a purificação do sangue. Igualmente, é gerador de preconceito, uma vez que as pessoas que sabem da condição do soropositivo, evitam tocar em objetos usados pelo portador do HIV.

$\mathrm{O}$ desejo de engravidar expõe a divergência entre crença e comportamento, que supera as recomendações para adoção de medidas preventivas, especificamente, quanto ao uso do preservativo por casal sorodiscordante. Neste estudo, ratifica-se que o conhecimento do perigo nem sempre determina, por si só, mudança de comportamento. As razões psicológicas para a separação entre crença e comportamento são complexas e englobam vários aspectos.

Nesta pesquisa, alguns colaboradores acreditam que Deus ou alguma força divina é que poderia "salvar" o filho e a eles também, sugerindo à purificação dos pecados, a elevação da alma do indivíduo doente, relacionando a metáfora ao destino dos que passam pelo infortúnio, que deverão ser recompensados pelo perdão divino e poderão desfrutar de uma graça.

Essa noção fortalece nos pais e mães soropositivos a responsabilidade pela doença e, conseqüentemente, a punição para o comportamento de pecado ou falha moral. Nesse caso, o sofrimento advindo das questões que envolvem a doença, como o tratamento e o preconceito, são formas de redimir a culpa, assinalando-a como uma doença punitiva.

Concluindo esta análise, verifico que este estudo mostrou que os pais e mães que aguardam a definição do diagnóstico do filho exposto ao HIV, sujeitos desta pesquisa, vivenciam um período de expectativas e medo do filho ter sido infectado, despertando-lhes preocupações com a sua saúde do filho, entretanto reconhecem a importância do tratamento e cumprem as recomendações médicas, simbolizando proteção à vida do filho, possuem esperança e confiança no resultado negativo da criança, mas a consolidação será dada por Deus, pela fé que devotam à 
entidade religiosa.

O estudo também permitiu compreender como as mulheres portadoras do HIV vivenciam a maternidade e como esse estado - ser mãe - condicionou o enfrentamento do processo saúde-doença, considerando seu contexto de vida, incluindo aqui suas condições sócioeconômicas, psicológicas e culturais. 


\section{CONCLUINDO O ESTUDO}

Em face dos pressupostos e objetivos apresentados neste estudo, julguei importante caracterizar as gestantes matriculadas no Projeto Transmissão Vertical Zero no período de 1998 a 2004, para delinear a situação dessas mulheres e, com base em uma abordagem qualitativa, desenhar sua vivência ao conviver com o filho exposto ao vírus da aids.

Do ponto de vista específico, pode-se concluir que as gestantes atendidas pelo Projeto, caracterizam-se como um grupo de adultas jovens, que estão na fase reprodutiva e são infectadas pelo HIV. Em sua maioria possuem ensino fundamental e não exercem atividades remuneradas. Há predomínio de união estável. Fato relevante é que o número de parceiros masculinos, relatados, por $82 \%$ das gestantes, no último ano precedente ao início do atendimento no Projeto, foi de um parceiro.

Deve-se considerar que $80 \%$ das gestantes mencionaram a realização do teste anti-HIV como indicação de rotina do pré-natal. Ressalta-se que $72 \%$ não acreditavam ser de risco para a infecção pelo HIV, enquanto que $28 \%$ declararam ter risco de contaminação pelo HIV.

Este grupo de gestantes caracteriza-se por viver em área urbana do município de Sorocaba, SP, e em sua maioria revelou situação socioeconômica favorável. Ao levantar questões pertinentes à vivência dessas mulheres e de seus parceiros, na porção qualitativa do estudo, foi possível compreender a vivência de mães e pais de lactente exposto, atendido pelo Projeto Transmissão Vertical Zero, 
diante da indefinição do diagnóstico de soropositividade para o HIV do filho, e que consistiu numa experiência sociocultural vivida de modo particular pelos participantes, entretanto, foi possível configurar o conjunto, pautado nas narrativas de 11 binômios, composto por 11 mães e sete pais moradores do município de Sorocaba, SP.

Desse repertório originou a construção dos temas delineados em sentimentos, espiritualidade e religiosidade, apoio, preocupação com a saúde do filho, preconceito e fazendo analogia, os quais possibilitaram identificar as expectativas e as ações adotadas pelos pais nesse período e assinalaram uma experiência marcada pela afetividade ao filho e pela expectativa diante da possibilidade de soropositividade ao HIV do filho.

A premissa que considerava ocorrer mudanças no cotidiano dos pais, durante esse período, em função das demandas da criança exposta ao HIV, não foi atestada integralmente, ao reconhecer poucas atitudes distintas das de pais de crianças não expostas. No entanto, o aspecto que demarca essa conjuntura está relacionado ao estigma e preconceito à aids, traço considerável da doença, exigindo empenho dos pais, que são obrigados a ocultar as atividades que envolvem o tratamento.

Ao analisar as narrativas na perspectiva cultural, emergiram as características desse grupo de pais, suas crenças ante a situação do filho exposto, e, sobretudo a maneira como enfrentam esse momento.

As expectativas embasam-se na ansiedade e na esperança em relação ao resultado negativo dos exames da criança. Diante desta contingência cotidiana, os pais e mães amparam-se na forte ligação com o filho, e na busca de apoio espiritual e religioso, mas também em menor escala no suporte oferecido por familiares.

Dentre os pressupostos confirmados, destaca-se a fé, manifestada na espiritualidade e religiosidade, no qual acreditar em um Deus dá forças para o enfrentamento dessa circunstância, - cura do filho -, expresso na "negativação" do exame. Outro aspecto da fé é contemplado no sucesso do tratamento, uma vez que os pais e mães consideram a obtenção da "cura", uma concessão de Deus, um poder sagrado proporcionado pelos medicamentos e a cura ocorre mediante a realização do acompanhamento e tratamento da criança.

Outra face da fé religiosa foi exibida pelo apoio prestado às famílias, 
além das práticas relativas à instituição religiosa, houve destino de provimentos, como fornecimento de alimentos, bens arrecadados e amparo social.

Dessa forma, concluo que esse grupo de mães e pais, que aguardam o diagnóstico definitivo do lactente, nega a transmissão do vírus ao filho, porque acredita no tratamento realizado durante a gestação e no parto, e para o bebê. Confia plenamente na dádiva de Deus para concretizar esse desejo, aguarda essa graça pela fé que devota à entidade religiosa, confirmando-se, assim, os pressupostos correspondentes.

A procura de apoio no círculo familiar demonstrou maior densidade na interação entre o casal e o filho, confirmando a família nuclear como fonte indispensável de apoio. Os demais familiares apareceram de forma pouco consistente, decorrentes de atitudes dos pais e mães para resguardarem-se de situações embaraçosas, provocadas pelo estigma e preconceito causados pela menção da doença.

Passar pela experiência de ter um filho exposto ao HIV foi articulado fortemente à própria existência da criança, ou seja, ter o filho ainda que nesta situação de soropositividade, representa uma enorme satisfação, mesmo em função do sofrimento causado pelas demandas da criança e do estresse causado pelo estigma e preconceito. Esses pais assumiram o cuidado e a criação do filho, transformaram esse infortúnio em subsídios que ajudaram na formação dos fatores promotores de Enfrentamento, que é respaldado nos valores e sentimentos que o filho trouxe, tornando-se, assim, em elementos essenciais para a construção dessas referências.

Um dos pressupostos que nortearam este estudo tratava da busca de apoio, na equipe de saúde, situação que não foi destacada pelos binômios, o que sugere não apresentarem dificuldades com relação ao âmbito institucional, representado pelas ações programáticas e a interação com os profissionais envolvidos.

Estes pais e mães mostraram que a experiência da maternidade e paternidade é mais intensa que a condição de soropositividade ao HIV. Os binômios mãe-pai mostraram-se felizes com a convivência do filho, sentem-se completos e a criança representa uma bênção em suas vidas, o que os conduz à busca de um sentido para suas vidas e os leva a encontrar na crença religiosa o apoio para o sofrimento causado pela soropositividade ao HIV.

Para ambos, pais e mães, essa conjuntura é significativa, incidindo 
sobre o casal, embora os achados do estudo mostrem uma distinção nas atribuições das mães, tanto na esfera biológica quanto na sociocultural. Dadas as questões inerentes aos papéis da mulher/mãe, que tem de conviver com vários ângulos nessa condição, seja na privação de atividades e comportamentos, seja no constante constrangimento, denunciado pela circunstância, o mais prejudicial parece ser o sentimento de culpa por colocar a vida do filho, seu bem mais precioso, em risco.

As expectativas pelo crescimento de uma criança saudável se fizeram presentes nas narrativas. Nem as adversidades verificadas no núcleo familiar no intervalo entre as duas dinâmicas, para coleta de dados, foram suficientes para arrefecer esta esperança.

Esta pesquisa forneceu subsídios para a compreensão da vivência do período de indefinição do diagnóstico do filho exposto ao HIV, uma vez que o grupo estudado desenvolveu uma forma de Enfrentamento a essa condição, o qual se baseia nas crenças, significados construídos pelas avaliações dos recursos disponíveis para enfrentar as adversidades relacionadas à doença, que serviram de suporte para sua vida na ocasião, situação que tipifica a influência da cultura no enfrentamento, uma vez que ela modela essas avaliações e a visão de mundo das pessoas.

O tema central que emergiu deste estudo - Enfrentamento - desvelou que o cotidiano do binômio mãe-pai é estampado pela ambigüidade de sentimentos, tal processo circunscrito pela afetividade é o mote para tolerar as adversidades e transtornos, e cultivar maneiras de enfrentar e resistir ao infortúnio, constituindo o Enfrentamento focalizado na emoção, que o binômio tenta regular a resposta emocional causada pela situação-problema apresentada, gerando atitudes de afastamento ou paliativas, representadas pela busca de apoio espiritual e religioso, e também suporte social.

Considero que a abordagem usada - Antropologia Médica possibilitou articular os valores e o sentido atribuído aos conceitos dos colaboradores estruturado na cultura, floresceu suas ações e a construção dos significados diante da situação. $\mathrm{O}$ estudo possibilitou visualizar as diferenças entre pensamento e ação social, para a busca da resolução dos problemas. Em síntese, foi possível capturar/reconhecer o contexto dos significados compartilhados e construídos por mães e pais e que servem de orientação para o comportamento, que é influenciado pela cultura. 


\section{TECENDO AS CONSIDERAÇÕES FINAIS}

Ao tecer as considerações finais deste estudo, enfatizo que investigar o fenômeno da interação do binômio mãe-pai com o filho, que se encontra no período de indefinição do diagnóstico para o HIV, ampliou o conhecimento e a compreensão deste período, e apontou implicações que podem alimentar áreas que envolvem a prática e o ensino de Enfermagem.

Neste aspecto, as mães e pais do grupo estudado assinalaram o preconceito e o estigma como principais fontes estressoras, acarretando sofrimento e sentimento de culpa, porém encontram refúgio e auxílio na espiritualidade e na fé religiosa, na dedicação ao filho e no apoio no interior do núcleo familiar. As estratégias de enfrentamento sustentam a situação e são incorporadas no cotidiano desses pais e mães para superação ou minimização dos conflitos.

O Projeto Transmissão Vertical Zero mostrou-se adequado à atenção oferecida ao núcleo familiar da mulher soropositiva ao HIV que gestou uma criança exposta ao vírus da aids. Nos primeiros quatro a seis meses de vida do lactente, a dupla mãe-pai não apontou lacunas no atendimento recebido neste serviço, por outro lado, aspectos sociais de seu cotidiano levaram a situações para as quais houve necessidade de enfrentamento.

Por outro lado, as informações geradas pelo estudo revelam possibilidades para melhorar a assistência aos portadores e suas famílias, desde que os profissionais da área da saúde estejam preparados e dispostos para explorar as situações da assistência que prestam às pessoas, buscando melhor compreender o 
significado das experiências relativas ao processo saúde-doença.

Os significados construídos demonstraram que é necessário, de modo geral, tornar mais abrangente o foco de atuação dos profissionais da área da saúde, principalmente da enfermagem, objetivando ampliar a visão do corpo biológico do indivíduo e incluir a compreensão dos referenciais adotados pelas pessoas envolvidas no processo, uma vez que se convivem no campo das relações humanas e afetivas. Devem ser considerados e incorporados em sua agenda, para a assistência e cuidados à saúde das mulheres, principalmente no período pós-parto, quando se encontram mais sensíveis e necessitam de apoio, privilegiando além do aspecto biológico, o envolvimento emocional e o contexto sociocultural.

As implicações para a Enfermagem são significativas e de grande extensão. As enfermeiras podem imprimir em suas atividades a perspectiva cultural, permitindo prestar um cuidado culturalmente embasado, com possibilidade de intervenções mais adequadas à clientela, serve igualmente como mecanismo para aumentar a consciência dos gestores e profissionais da saúde para o aperfeiçoamento das estratégias educativas, de aconselhamento e cuidados aos portadores do HIV/Aids.

Para tanto, há que se trabalhar nos dois pólos de formação profissional concomitantemente, na graduação dos profissionais da área da saúde, e na educação permanente, com conteúdos e abordagens que extrapolem os contemplados no atual modelo biomédico de formação e assistência. Na interação profissional-cliente, alguns ingredientes são necessários para que tal interação se estabeleça, sendo uma delas o processo de comunicação, especificamente a habilidade de escuta e de atitudes atenciosas, que têm potencial para influir substancialmente, na relação entre clientes e profissionais, propiciando intervenções eficazes, que poderiam melhorar a qualidade da assistência, uma vez que há o ponto de vista das pessoas.

Nesse contexto, é fundamental a participação de todos os profissionais da área da saúde na promoção de fatores de proteção e de resiliência, considerando o papel de extrema importância desses profissionais para os portadores da infecção pelo HIV. Tratar os temas que envolvam o Enfrentamento, a espiritualidade, a religiosidade nos currículos de Enfermagem e demais áreas da saúde é uma situação que clama para uma implantação e implementação, com a finalidade de resgatar a dimensão espiritual que é uma das formas apontadas pelos colaboradores desta 
pesquisa que confirmam a dimensão espiritual e a fé religiosa para minimizar o sofrimento.

Essa atuação corrobora as ações institucionais estabelecidas para a área, tanto as implantadas pelos gestores, como as da rede de apoio, representados pelas ONGs, que trabalham voltadas para a HIV/Aids. Dessa forma, a manutenção dessas ações para a redução da transmissão vertical do HIV no Brasil são importantes, avalizadas na assistência ao pré-natal, parto e nascimento, e no período pós-parto. Apesar dos objetivos valorosos dessas estratégias governamentais, o seu alcance ainda é restrito, suscitando o conselho/observações para que a testagem rápida seja oferecida universalmente às parturientes na maternidade na ocasião do parto, resguardando sempre seu caráter voluntário e confidencial; medida que acredito ampliar as chances de prevenção da transmissão vertical do HIV.

Não descuida das ações de prevenção, as quais deverão ter ênfase, tanto nos aspectos específicos da prevenção ao HIV, incluindo a vulnerabilidade das mulheres, as repercussões sobre a gravidez, e também em suas famílias, como de operar com recursos que encorajem a discussão dos temas do preconceito, agir como pontes entre os portadores e os profissionais/cuidadores de saúde por meio da estimulação ao diálogo aberto e implementando programas de esclarecimento que possam atenuar os prejuízos advindos do preconceito e estigmatização.

Ao trabalhar nesta linha há chances de demolir os temas relacionados à aids, tais como: estigma, discriminação, saúde reprodutiva prejudicada. Estes devem fazer parte do esforço de promoção de saúde, na construção de ambientes encorajadores para eliminar o sofrimento desnecessário causado por ser portador do HIV, e ao procurar envolver toda a sociedade nessas atividades para desenvolver um padrão de convivência com os portadores. As estratégias de enfrentamento podem ser sugeridas e estimuladas em um contexto sociocultural. Há uma lacuna na utilização do conceito de enfrentamento/resiliência na área da Enfermagem, contribuindo para um redimensionamento do cotidiano profissional.

Em adição, esta visão resgata uma concepção do ser humano como alguém que busca a sua felicidade, bem-estar e saúde, tendo potencial para desenvolver estratégias para conseguir esse objetivo. A situação de infecção pelo HIV/Aids pode ser de extrema adversidade, mas pode ser (re)significada e até vivida como fonte potencial para a mudança e para novas oportunidades diante da vida. 
Os achados deste estudo também evidenciam a necessidade de as intervenções para a prevenção da transmissão do HIV serem culturalmente embasadas, considerando as crenças, as informações e as necessidades do grupo-alvo e, dessa maneira, despertá-lo para reflexões e para provocar alterações de comportamento diante da epidemia da Aids.

Ao finalizar este estudo, reforço a importância de uma ação contínua para a construção do conhecimento da Enfermagem sobre a aids e a participação do enfermeiro atuando, em equipe multidisciplinar, em programas de intervenção que propiciem a redução do número de infectados pelo HIV e prestando assistência adequada, levando em conta os aspectos socioculturais. 


\section{REFERÊNCIAS}

Abeyá R, Sá RAM, Silva EP, Chaves Netto H, Bornia RG, Amin Jr J. Complicações perinatais em gestantes infectadas pelo vírus da imunodeficiência humana. Rev Saúde Matern Infant. 2004;4(4):385-90.

Aguiar JM, Simões-Barbosa RH. Relações entre profissionais de saúde e mulheres HIV+: uma abordagem de gênero. Cad Saúde Pública. 2006;22(10):2115-23.

Almeida JM. Representações sociais sobre Aids e sua influência no processo ensinoaprendizagem de um grupo de alunas de enfermagem da PUC-SP [dissertação]. Sorocaba: Universidade de Sorocaba; 1999.

Almeida MRCB, Labronici LM. A trajetória silenciosa de pessoas portadoras do HIV contada pela história oral. Ciênc Saúde Coletiva. 2007;12(1):263-74.

Alonso IK. O cuidado da enfermagem na saúde da família: sob o olhar da antropologia da saúde. Rev Téc Cient Enferm. 2003;1(1):60-5.

Andrade OG. Representações sociais de saúde e de doença na velhice. Acta Sci Health Sci. 2003;25(2):207-13.

Antoniazzi AS, Dell'Aglio DD, Bandeira DR. O conceito de coping: uma revisão teórica. Estud Psicol (Natal). 1998;3(2):273-94.

Araújo MAL, Vieira NFC, Bucher JSNF. Aconselhamento pré e pós-teste anti-HIV como estratégia de melhoria da cobertura de testagem em gestantes e prevenção da transmissão vertical do HIV. Bol Epidemiol Aids DST. 2006;3(1):16-21.

Athaniel MAS. Significados e Implicações de ser mãe no processo saúde-doença de mulheres com aids [dissertação]. São Paulo: Escola de Enfermagem, Universidade de São Paulo; 2006. 
Aversari ES, Castro TC, Castro PF. A avaliação psicológica de portadores do vírus a partir do Rorschach. In: Resumos de Biociências do $4^{\circ}$. Encontro de Iniciação Científica; 1999 out. 19-21; Taubaté, BR. Taubaté: UNITAU; 1999. p. 371.

Azevedo AF, Guilhem D. A vulnerabilidade da gestante na situação conjugal de sorodiferença para o HIV/Aids. DST J Bras Doenças Sex Transm. 2005;17(3):18996.

Azevedo KML. Transmissão vertical do vírus da imunodeficiência humana: como reduzir o risco? J Bras DST. 2001;13(6):49-53.

Barbosa RHS. Mulheres, reprodução e Aids: as tramas da ideologia na assistência à saúde de gestantes HIV+ [tese]. Rio de Janeiro: Escola Nacional de Saúde Pública, Fundação Oswaldo Cruz; 2001.

Barroso LMM, Carvalho CML, Araújo TL, Galvão MTG. Autocuidado de uma mulher com Aids: um modelo de cuidar em enfermagem. Online Brazilian Journal of Nursing. [periódico na internet]. 2006 ago. [citado 2007 ago 20];5(2):[cerca de 15 p.]. Disponível em http://www.uff.br/objnursing/index.php/nursing/article/viewArticle/289/55.

Barroso LMM, Carvalho CML, Araújo TL, Galvão MTG, Vieira NFC, Barroso MGT. Aspectos éticos da interação enfermeiro-puérpera com HIV/Aids. DST J Bras Doenças Sex Transm. 2005;17(3):197-200.

Barroso M, Miranda CCL, Pinheiro PNC. A Aids sob o olhar da companheira. Rev Bras Enferm 1998; 51(3): 379-92.

Batista E. Parceria garante assistência à gestante com vírus HIV. Cruzeiro do Sul. 1999 ago. 22; Cidades: p. A-3

Blaxter M. Life narratives, health and identity. In: Kelleher D, Leavey G. Identity and health. London: Routledge; 2004. p. 170-99.

Boehs AE. Que poder a enfermeira utiliza na abordagem cultural do cuidado à família? Rev Enferm UERJ. 1999;7(1):61-7.

Braga PE, Cardoso MRA, Segurado AC. Diferenças de gênero ao acolhimento de pessoas vivendo com HIV em serviço universitário de referência de São Paulo, Brasil. Cad Saúde Pública. 2007;23(11):2653-62.

Brasil. Ministério da Saúde. Aids: etiologia, clínica, diagnóstico e tratamento: Unidade de Assistência [texto na Internet]. Brasília; 1999a [citado 2007 dez. 12]. Disponível em: http://www.aids.gov.br/assistencia/etiologia_diagnostico.htm 
Brasil. Ministério da Saúde. Boletim Epidemiológico Aids. Brasília; 1999 b.

Brasil. Ministério da Saúde. Parto, aborto e puerpério: assistência humanizada à mulher. Brasília; 2001.

Brasil. Ministério da Saúde. Políticas e diretrizes de prevenção das DST/Aids entre mulheres. Brasília; 2003a.

Brasil. Ministério da Saúde. Projeto Nascer. Brasília; 2003b.

Brasil. Ministério da Saúde. Programa nacional de atenção integral à saúde da mulher: princípios e diretrizes. Brasília; 2004a. (Série C. Projetos, programas e relatórios).

Brasil. Ministério da Saúde. Guia de Tratamento Clínico da infecção HIV em Crianças. Brasília; 2004b. (Série: Normas e Manuais Técnicos, 120).

Brasil. Ministério da Saúde. Boletim Epidemiológico Aids e DST. Brasília; 2004c.

Brasil. Ministério da Saúde. Projeto de Implementação da Vigilância da Aids, da sífilis na gestação e congênita, nas regiões Norte e Nordeste [texto na Internet]. Brasília; 2005a. [citado 2005 out. 9]. Disponível em: http://www.aids.gov.br/final/novidades/macrorregionais/ApresentaçãoProjetoVE.ppt.

Brasil. Ministério da Saúde. Marco legal: saúde, um direito de adolescentes. Brasília: Ministério da Saúde; 2005b. (Série A. Normas e Manuais Técnicos).

Brasil. Ministério da Saúde. Manual normativo para profissionais de saúde de maternidades: referência para mulheres que não podem amamentar. Brasília; 2006. (Série Manuais).

Brasil. Ministério da Saúde. Programa Nacional de DST e Aids. Plano Operacional para Redução da Transmissão vertical do HIV e da Sífilis no Brasil. Brasília; 2007a.

Brasil. Ministério da Saúde. Boletim Epidemiológico Aids e DST. Brasília; 2007b.

Brasil. Ministério da Saúde. Recomendações para profilaxia da transmissão vertical do HIV e Terapia Anti-Retroviral em Gestantes. Brasília; 2007c.

Brasil VV. Grupos de mulheres e histórias de vida: por um processo de desnaturalização na prevenção do HIV. In: Czeresnia D, organizadora. Aids: pesquisa social e educação. São Paulo: Hucitec; 1995. p. 105-21.

Brito AM, Castilho EA, Szwarcwald CL. Aids e infecção pelo HIV: uma epidemia multifacetada. Rev Soc Bras Med Trop. 2000;34(2):207-17. 
Brito AM, Sousa JL, Luna CF, Dourado I. Tendência da transmissão vertical de Aids após terapia anti-retroviral no Brasil. Rev Saúde Pública. 2006;40 Supl:18-22.

Brito N, Cruz EF. Fios da vida: tecendo o feminino em tempos de aids. Grupo de Incentivo à Vida e Coordenação Nacional de DST e Aids [relatório de pesquisa na Internet]. Brasília; 2003. [citado 2005 nov. 25]. Disponível em:

http://www.aids.gov.br/final/biblioteca/fios_vid/creditos.htm.

Camargo Júnior KR. Debate sobre o artigo de Fry et al. Cad Saúde Pública. 2007;23(3):508-10.

Canesqui AM. Notas sobre a produção acadêmica de antropologia e saúde na década de 80. In: Alves PC, Minayo MCS, organizadores. Saúde e Doença: um olhar antropológico. $2^{\text {a }}$ ed. Rio de Janeiro: FIOCRUZ; 1994. p. 13-32.

Canesqui AM. Os estudos de antropologia da saúde/doença no Brasil na década de 1990. Ciênc Saúde Coletiva. 2003;8(1):109-24.

Carr RL, Gramling LF. Stigma: A Health Barrier for Women With HIV/AIDS. J Assoc Nurses AIDS Care. 2004;15(5):30-9.

Carvalho CML, Braga VAB, Galvão MTG. Aids e saúde mental: revisão bibliográfica. DST J Bras Doenças Sex Transm. 2004;16(4):50-5.

Carvalho FT, Morais NA, Koller SH, Piccinini CA. Fatores de proteção relacionados à promoção de resiliência em pessoas que vivem com HIV/Aids. Cad Saúde Pública. 2007;23(9):2023-33.

Carvalho FT, Piccinini CA. Maternidade em situação de infecção pelo HIV: um estudo sobre os sentimentos de gestantes. Interação Psicol. 2006;10(2):345-55.

Castanha AR, Coutinho MPL, Saldanha AAW, Ribeiro CG. Aspectos psicossociais da vivência da soropositividade ao HIV nos dias atuais. Psico. 2006;37(1):47-56.

Castanha AR, Coutinho MPL, Saldanha AAW, Ribeiro CG. Avaliação da qualidade de vida em soropositivos para o HIV. Estud Psicol (Campinas). 2007;24(1):23-31.

Castro EK, Moreno-Jimenez, B. Resiliência em crianças com doenças crônicas: aspectos teóricos. Psicol Estud. 2007;12(1):81-6.

Castro R, Eroza H, Orozco E, Manca MC, Hernádez JJ. Estrategias de manejo em torno al VIH/SIDA a nível familiar. Salud Pública Méx. 1997;39(1):32-43. 
Cavalcante MS, Ramos Jr AN, Silva TMJ, Pontes LRSK. Transmissão vertical do HIV em Fortaleza: revelando a situação epidemiológica em uma capital do Nordeste. Rev Bras Ginecol Obstet. 2004;26(2):131-8.

Ceia C, coordenador. E-Dicionário de Termos Literários [livro na internet]. Lisboa; c2005 [citado 2007 out. 15]. Disponível em:

http://www.fcsh.unl.pt/edtl/verbetes/A/analogia.htm.

Chequer P. Apresentação. Bol Epidemiol AIDS DST. 2005;2(1):3-5.

Chor D, Griep RH, Lopes CS, Faerstein E. Medidas de rede e apoio social no Estudo Pró-Saúde: pré-testes e estudo piloto. Cad Saúde Pública. 2001;17(4):887-96.

Contim D, Chaud MN, Fonseca AS. As questões familiares e a criança e o adolescente com doença crônica: um estudo de revisão bibliográfica. Nursing (São Paulo). 2005;85(8):267-71.

Cunha CC. Revelando vozes, desvendando olhares: os significados do tratamento para o HIV/AIDS [dissertação]. Rio de Janeiro: Escola Nacional de Saúde Pública, Fundação Oswaldo Cruz; 2004.

David GLB, Elsen I. Ética nas relações entre enfermagem e famílias com Aids. Texto Contexto Enferm. 2000; 9(2):590-9.

Del Bianco R, Kuschnaroff TM, Santos NJS. Prevenção da transmissão vertical do HIV em cinco maternidades do município de São Paulo. J Bras Aids. 2005;6(5):192209.

Duarte G, Quintana SM, El Beitume P. Fatores que influenciam a transmissão vertical do vírus da imunodeficiência humana tipo 1. Rev Bras Ginecol Obstet. 2005;27(11):698-705.

Duarte R. Pesquisa qualitativa: reflexões sobre o trabalho de campo. Cad Pesqui. 2002;(115):139-54.

Faria JB, Seidl EMF. Religiosidade e enfrentamento em contextos de saúde e doença: revisão da literatura. Psicol Reflex Crítica. 2005;18(3):381-9.

Faria JB, Seidl EMF. Religiosidade, enfrentamento e bem-estar subjetivo em pessoas vivendo com HIV/Aids. Psicol Estud. 2006;11(1):155-64.

Farias FLR, Furegato ARF. O dito e o não dito pelos usuários de drogas, obtidos mediante as vivências e da técnica projetiva. Rev Lat Am Enferm. 2005;13(5):700-7. 
Farias N, Cardoso MRA. Mortalidade por Aids e indicadores sociais no Município de São Paulo: 1994 a 2002. Rev Saúde Pública. 2005;39(2):198-205.

Fernandez RCSC, Araújo LC, Medina-Acosta E. O desafio da prevenção da transmissão vertical do HIV no município de Campos dos Goytacaz, Rio de Janeiro, Brasil. Cad Saúde Pública. 2005;21(4):1153-9.

Ferraz AF, Stefanelli MC Interações familiares de pessoas vivendo com HIV e Aids. Rev. Min Enferm. 2001;5(1/2):52-9.

Ferreira FC. As condições que levam as mulheres soropositivas ao HIV/AIDS a abrir a privacidade de suas informações às equipes do programa saúde da família [dissertação]. São Paulo: Escola de Enfermagem, Universidade de São Paulo; 2007.

Fioroni LN, Figueiredo MAC. Levantamento de perfis psicológicos de pessoas com Aids, através da técnica projetiva de Rorschach. In: Anais do $3^{\circ}$. Encontro da Sociedade Brasileira de Rorschach; 2000; Ribeirão Preto, BR. Ribeirão Preto: SBRo; 2000. v. 1, p. 295-8.

Fleck MPA. O instrumento de avaliação de qualidade de vida da Organização Mundial de Saúde (WHOQOL-100): características e perspectivas. Ciênc Saúde Coletiva. 2000;5(1):33-8.

Fleck MPA, Borges ZN, Bolognesi G, Rocha NS. Projeto WHOQOL-OLD: método e resultados de grupos focais no Brasil. Rev Saúde Pública. 2003;37(4):446-55.

Fleck MPA, Louzada S, Xavier M, Chachamovich E, Vieira G, Santos L, et al. Aplicação da versão em português do instrumento abreviado de avaliação da qualidade de vida "WHOQOL-bref". Rev Saúde Pública. 2000;34(2):178-83.

Folle E, Geib LTC. Representações sociais das primíparas adolescentes sobre o cuidado materno ao recém-nascido. Rev Lat Am Enferm. 2004;12(2):183-90.

Fonseca MGP, Bastos FI. Twenty-five years of the AIDS epidemic in Brazil: principal epidemiological findings, 1980-2005. Cad Saúde Pública. 2007; 23 Supl 3: S333-44.

Fonseca MGP, Bastos FI, Derrico M, Andrade CLT, Travassos C, Szwarcwald CL. Aids e grau de escolaridade no Brasil: evolução temporal de 1986 a 1996. Cad Saúde Pública. 2000;16 Supl 1: 77-87.

Fry PH, Monteiro S, Maio MC, Bastos FI, Santo RV. Aids tem cor ou raça? Interpretação de dados e formulação de políticas de saúde no Brasil. Cad Saúde Pública. 2007;23(3):497-523. 
Fullilove RE, Green L, Fullilove MT. The family to family program: a structural intervention with implications for the prevention of HIV/Aids and other community epidemics. AIDS. 2000;14 Suppl 1: S63-7.

Galvão J. A Aids na mídia: da "cura" ao mercado. In: Oliveira F, Galvão J, Greenhalgh L, Rios LF, Pazello M, Citeli MT, et al. Olhar sobre a Mídia. Belo Horizonte: Mazza; 2002. p. 77-101.

Galvão MTG, Cerqueira ATAR, Machado JM. Avaliação de qualidade de vida de mulheres com HIV/Aids através do HAT-QoL. Cad Saúde Pública. 2004;20(2):43037.

Geertz C. A interpretação das culturas. Rio de Janeiro: LTC; 1989.

Gianvecchio RP, Goldberg TBL. Fatores protetores e de risco envolvidos na transmissão vertical do HIV-1. Cad Saúde Pública. 2005;21(2):581-8.

Goffman E. Estigma: notas sobre a manipulação da identidade deteriorada. $4^{\mathrm{a}}$ ed. Rio de Janeiro: LTC; 1988.

Gotardo GIB. A percepção de mulheres sobre a assistência recebida em seu processo de ser mãe: um cenário de bons e maus-tratos [tese]. São Paulo: Escola de Enfermagem, Universidade de São Paulo; 2003.

Gramacho PM, Bacarji JEW. Projeção investigada através de desenhos de crianças com câncer. Acta Oncológica Brasileira. 2004;24(3):649-60.

Gray J, Cason CL. Mastery over stress among women with HIV/Aids. J Assoc Nurses AIDS Care. 2002;13(4):43-57.

Griep RH, Chor D, Faerstein E, Werneck G, Lopes CS. Validade de constructo de escala de apoio social do Medical Outcomes Study adaptada para o português no Estudo Pró- Saúde. Cad Saúde Pública. 2005;21(3):703-14.

Grupo de Incentivo à Vida (GIV) [homepage na Internet]. São Paulo; c2005-2007. [citado 2005 out. 7]. Disponível em: http://www.giv.org.br/redepaulista.htm.

Gualda DMR, Bergamasco RB. Enfermagem, cultura e o processo saúde-doença. São Paulo: Ícone; 2004. Processo saúde-doença: evolução de um conceito; p. 25-37.

Hammer EF. Aplicações Clínicas dos Desenhos Projetivos. Rio de Janeiro: Interamericana; 1991.

Hammersley M, Atkinson P. Ethnography: principles in practice. New York: Tavistock; 1995. 
Helman CG. Cultura, saúde \& doença. 4ª ed. Porto Alegre: Artmed; 2003.

Hoga LAK. As práticas anticoncepcionais no cotidiano de uma comunidade. In: Merighi MAB, Praça NS. Abordagens teórico-metodológicas qualitativas: a vivência da mulher no período reprodutivo. Rio de Janeiro: Guanabara Koogan; 2003. p. 4757.

Inouye J, Flannelly L, Flannelly KJ. The effectiveness of self-management training for individuals with HIV/AIDS. J Assoc Nurses AIDS Care. 2001;12(1):73-84.

Instituto Patrícia Galvão. Mulheres com HIV/Aids: elementos para a construção de direitos e qualidade de vida. São Paulo: Comunicação e Mídia; 2003.

Job FPP. Resiliência nas organizações: estudo de caso da medição e avaliação da resiliência de indivíduos em uma organização industrial. Rev Fac Ciênc Méd Sorocaba. 2003;5(1):33-42.

Job JRP. A Escritura da Resiliência: Testemunhas do holocausto e a memória da vida [tese]. São Paulo: Faculdade de Psicologia, Pontifícia Universidade Católica de São Paulo; 2000.

Johnson MO, Lobo ML. Mother-child interaction in the presence of maternal HIV infection. J Nurses AIDS Care. 2001;12(1):40-51.

Kern FA. Mulheres soropositivas: a visibilidade e a invisibilidade da representação social da Aids. Rev Virtual Textos Contextos [periódico na internet]. 2003 dez. [citado 2007 out 12];2(2):[cerca de 16 p.]. Disponível em:

http://revistaseletronicas.pucrs.br/ojs/index.php/fass/article/viewFile/962/742.

Kovács MJ. Espiritualidade e psicologia: cuidados compartilhados. Mundo Saúde. 2007;31(2):246-55.

Lagonegro ER. Aids: a epidemia em transformação. Prática hospitalar. 2005;7(40):21-6.

Lazarus RS, Folkman S. Stress, appraisal, and coping. New York: Springer; 1984.

Landroni MAS. Aids e gravidez: desafios para o cuidado nos serviços de saúde [dissertação]. São Paulo: Faculdade de Saúde Pública, Universidade de São Paulo; 2004.

Lemos CG. O desenho de profissionais com estórias na orientação profissional [texto na Internet]. São Paulo; 2002 [citado 2005 jul. 13]. Disponível em: http://www.psicopedagogia.com.br/artigos/artigo.asp?entrID=341. 
Lemos LMD, Gurgel RQ, Fabbro ALD. Prevalência da infecção por HIV em parturientes de maternidades vinculadas ao SUS. Rev Bras Ginecol Obstet. 2005;27(1):32-6.

Lira GV, Catrib AMF, Nations MK. A narrativa na pesquisa social em saúde: perspectiva e método. Rev Bras Promoção Saúde. 2003;16(1/2):59-66.

Litwinczuk KM, Groh CJ. The relationship between spirituality, purpose in life, and well-being in HIV-positive persons. J Assoc Nurses AIDS Care. 2007;18(3):13-22.

Lopes GT, Spíndola T. Sentimentos de Mães de portadores de Aids. Rev Enferm UERJ. 1994;2(2):183-91.

Luzardo AR, Waldman BF. Atenção ao familiar cuidador do idoso com doença de Alzheimer. Acta Sci Health Sci. 2004;26(1):135-45.

Lynne D. Suffering, shame, and silence: The Stigma of HIV/AIDS. J Assoc Nurses AIDS Care. 2005;16(1):13-20.

Machado AA, Costa JC. Métodos laboratoriais para o diagnóstico da infecção pelo vírus da imunodeficiência humana (HIV). Medicina. 1999;32(2):138-46.

Majumdar B. An exploration of socioeconomic, spiritual and family support among hiv-positive women in India. J Assoc Nurses AIDS Care. 2004;15(3):37-46.

Marques LF. A saúde e o bem-estar espiritual em adultos porto-alegrenses. Psicol Ciênc Prof. 2003;23(2):56-65.

Maruyama SAT. A experiência da colostomia por câncer como ruptura biográfica na visão dos portadores, familiares e profissionais de saúde: um estudo etnográfico [tese]. Ribeirão Preto: Escola de Enfermagem de Ribeirão Preto, Universidade de São Paulo; 2003.

Medina NVJ, Takahashi RT. A busca da graduação em enfermagem como opção dos técnicos e auxiliares de enfermagem. Rev Esc Enferm USP. 2003;37(4):101-8.

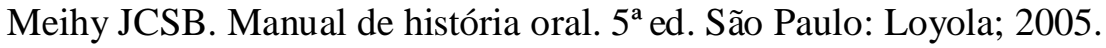

Melo VH. Transmissão materno-fetal do vírus da imunodeficiência humana (HIV). Femina. 1999;27(5):405-12.

Merighi MAB, Praça NS. Abordagens teórico-metodológicas qualitativas: a vivência da mulher no período reprodutivo. Rio de Janeiro: Guanabara-Koogan; 2003. 
Minayo MCS. O desafio do conhecimento: pesquisa qualitativa em saúde. $7^{\mathrm{a}}$ ed. São Paulo: Hucitec; 2000.

Miranda FAN, Andrade OG, Furegato ARF, Rodrigues RAP. Representação social da sexualidade entre idosos institucionalizados. UNOPAR Cient Ciênc Biol Saúde. 2005;7(1):27-34.

Miranda FAN, Furegato ARF. Percepções da sexualidade do doente mental pelo enfermeiro. Rev Lat Am Enferm. 2002;10(2):207-13.

Miranda KCL, Teixeira JMC. A ética e o cuidar reflexivo em HIV/Aids. J Bras Aids. 2006;7(3):121-68.

Monticelli M, Santos EKAS, Erdmann AL. Ser-mãe HIV-positivo: significados para mulheres HIV positivo para a Enfermagem. Acta Paul Enferm. 2007;20(3):291-8.

Moreno CCGS, Rea MF, Filipe EV. Mães HIV positivo e a não-amamentação. Rev Bras Saúde Matern Infant. 2006;6(2):199-208.

Moura EL. Transmissão Vertical do HIV: percepção e ações da gestante soropositiva [dissertação]. São Paulo: Escola de Enfermagem, Universidade de São Paulo; 2002.

Moura EL, Praça NS. Transmissão vertical do HIV: expectativas e ações da gestante soropositiva. Rev Lat Am Enferm. 2006;14(3):405-13.

National Pediatric \& Family HIV Resource Center. Working with parents im HIVaffected Families: a guide for providers. Newark; 2001.

Neves LAS. Prevenção da transmissão vertical do HIV/Aids: compreendendo as crenças e percepções das mães soropositivas [dissertação]. Ribeirão Preto: Escola de Enfermagem de Ribeirão Preto, Universidade de São Paulo; 2005.

Neves LAS, Gir E. Crenças das mães soropositivas ao HIV acerca da transmissão vertical da doença. Rev Lat Am Enferm. 2006;14(5):781-8.

Ortolam R, Souza MFM. A atuação da associação crianças de Belém no combate a transmissão materno-infantil do HIV na cidade de Sorocaba [texto na internet]. Sorocaba: Portal Saúde Brasil; 2004 [citado 2005 out. 9]. Disponível em: http://www.saudebrasilnet.com.br/premios/aids/premio1/trabalhos/012.pdf.

Padoin SMM, Paula CC, Schaurich D, Fontoura VA, organizadores. Experiências interdisciplinares em aids: interfaces de uma epidemia. Santa Maria: UFSM; 2006.

Paiva SS, Galvão MTG. Sentimentos diante da não amamentação de gestantes e puérperas soropositivas para HIV. Texto Contexto Enferm. 2004;13(3):414-9. 
Paiva V, Lima TN, Santos N, Ventura-Filipe E, Segurado A. Sem direito de amar? A vontade de ter filhos entre homens (e mulheres) vivendo com o HIV. Psicol USP. 2002;13(2):105-33.

Paludo SS, Koller SH. Resiliência na rua: um estudo de caso. Psicol Teor Pesqui. 2005;21(2):187-95.

Pan-American Health Organization (PAHO). Women and HIV/Aids: prevention and care strategies. Washington; 2000.

Parker R, Galvão J. Quebrando o silêncio: mulheres e Aids no Brasil. Rio de Janeiro: Relume-Dumará; 1996.

Pedro ENR, Stobäus CD. Vivências e (con)vivências de crianças portadoras do HIV/AIDS e seus familiares; implicações educacionais. Rev Paul Enferm. 2003;22(1):62-71.

Pereira MAO. Representação da doença mental pela família do paciente. Interface Comunic Saúde Educ. 2003;7(12):71-82.

Pesce RP, Assis SG, Santos N, Oliveira RVC. Risco e proteção: em busca de um equilíbrio promotor de resiliência. Psicol Teor Pesqui. 2004;20(2):135-43.

Pessini L. A Espiritualidade interpretada pelas ciências e pela saúde. Mundo Saúde. 2007;31(2):187-95.

Pinheiro PNC, Barroso MGT. Mães soropositivas: reações em meio ao HIV/Aids. Rev RENE. 2004;5(1):9-14.

Praça NS. Pesquisa qualitativa, ensino e assistência de enfermagem: interação que favorece o cuidado cultural. Cienc Enferm. 2003;9(2):67-75.

Praça NS, Barrancos JTG. Teste anti-HIV e aconselhamento no pré-natal: percepção de puérperas. Rev Gaúcha Enferm. 2007;28(1):106-16.

Praça NS, Gualda DMR. Percepção de risco para HIV/Aids de mulheres faveladas segundo o modelo de crenças em saúde. Rev Esc Enferm USP. 2001;35(1):54-9.

Praça NS, Latorre MRDO. Saúde sexual e reprodutiva com enfoque na transmissão do HIV: práticas de puérperas atendidas em maternidades filantrópicas do município de São Paulo. Rev Bras Saúde Matern Infant. 2003;3(1):61-74.

Prado G, Feaster DJ, Schwartz SJ, Pratt IA, Smith L, Szapocznik J. Religious involvement, coping, social support, and psychological distress in HIV-Seropositive african american mothers. AIDS Behav. 2004;8(3):221-35. 
Programa reduz em $82 \%$ infecção de bebês pelo vírus HIV. Cruzeiro do Sul. 2000 dez. 3; Caderno Cidades: A-9.

Raynaut C. Interfaces entre a antropologia e a saúde: em busca de novas abordagens conceituais. Rev. Gaúcha Enferm 2006;27(2):149-65.

Ramos LMA, Bagnato MHS. Considerações sobre a proposta educativa de prevenção da AIDS em locais de trabalho da Coordenação Nacional de DST/AIDS do Ministério da Saúde. ETD Educ Temát Digital. 2002;4(1):1-9.

Ramos Júnior NA, Matida LH, Saraceni V, Veras MASM, Pontes RJS. Control of mother-to-child transmission of infectious diseases in Brazil: progress in HIV/Aids and failure in congenital syphilis. Cad Saúde Pública. 2007;23 Supl 3: S370-8.

Retondo, MFNG. Manual Prático de Avaliação do HTP (Casa-Árvore-Pessoa) e Família. São Paulo: Casa do Psicólogo; 2000.

Ribeiro CG, Castanha AR, Coutinho MPL, Saldanha AAW. A Aids e suas contradições: representações sociais de seu atendimento e tratamento pelos profissionais e pacientes. DST J Bras Doenças Sex Transm. 2005;17(2):127-32.

Rodrigues Júnior AL, Castilho EA. A epidemia de AIDS no Brasil, 1991-2000: descrição espaço-temporal. Rev Soc Bras Med Trop. 2004;37(4):312-7.

Rollins N, Meda N, Becquet R, Coutsoudis A, Humphrey J, Jeffrey B, et al. Preventing postnatal transmission of HIV-1 through breast-feeding: modifying infant feeding practices. J Acquir Immune Defic Syndr. 2004;35(2):188-95.

Romanelli RMC, Kakehasi FM, Tavares MCT, Melo VH, Goulart LHF, Aguiar RALP, et al. Perfil das gestantes infectadas pelo HIV atendidas em pré-natal de alto risco de referência de Belo Horizonte. Rev Bras Saúde Matern Infant. 2006;6(3):32934.

Rose MA, Clark-Alexander B. Quality of life and coping styles of HIV-positive women with children. J Assoc Nurses AIDS Care. 1996;7(2):28-34.

Sá AC, Pereira LL. Espiritualidade na enfermagem brasileira: retrospectiva histórica. Mundo Saúde. 2007;31(2):225-37.

Saad M, Masiero D, Battistella LR. Espiritualidade baseada em evidências. Acta Fisiátrica. 2001;8(3):107-12.

Sampaio Neto LF, Silva SC, Condi G, Pinto PCC, Novo NF. O impacto do conhecimento prévio da soropositividade em parturientes. DST J Bras Doenças Sex Trasm. 2002;14(5):20-4. 
Santos NJS, Buchalla CM, Fillipe EV, Bugamelli L, Garcia S, Paiva V. Mulheres HIV positivas, reprodução e sexualidade. Rev Saúde Pública. 2002;36 Supl 4: S1223.

Schuster MA, Kanouse DE, Morton SC, Bozzette AS, Mil A, Scott GB, et al. HIVinfected parents and their children in the United States. Am J Public Health. 2000;90(7):1074-81.

Seidl EMF. Enfrentamento, aspectos clínicos e sociodemográficos de pessoas vivendo com HIV/Aids. Psicol Estud. 2005;10(3):421-29.

Seidl EMF, Rossi WS, Viana KF, Meneses AKF, Meireles E. Crianças e adolescentes com HIV/Aids e suas famílias: aspectos psicossociais e enfrentamento. Psicol Teor Pesqui. 2005;21(3):279-88.

Seidl EMF, Tróccoli BT, Zannon CMLC. Análise fatorial de uma medida de estratégias de enfrentamento. Psicol Teor Pesqui. 2001;17(3):225-34.

Seidl EMF, Zannon CMLC, Tróccoli BT. Pessoas vivendo com HIV/Aids: enfrentamento, suporte social e qualidade de vida. Psicol Reflex Crít. 2005;18(2):188-95.

Sherlock MSM, Vieira NFC. Preocupações de mães soropositivas com o HIV e suas implicações para o cuidado de enfermagem. J Bras DST. 1999;11(4):5-9.

Sherr L, Barry N. Fatherhood and HIV positive heterosexual men. HIV Med. 2004;5(4):258-63.

Silva CA, Carvalho LS, Camargo CL, Santos ACPO, Menezes MR. História oral e pesquisas qualitativas em enfermagem. Online Braz J Nurs [periódico na Internet]. 2006 [citado 2007 set. 1];5(3):[cerca de 12 p.]. Disponível em: http://www.uff.br/objnursing/index.php/nursing/article/viewArticle/487/110.

Silva DGV, Trentini M. Narrativas como técnica de pesquisa em enfermagem. Rev Lat Am Enferm. 2002;10(3):423-32.

Silva IA. Significados atribuídos à abstinência de amamentação por mulheres HIV positivas. Ciênc Cuid Saúde. 2005;4(1):13-24.

Silva MFX. A intervenção terapêutica breve e a pré-cirurgia infantil. Psico-USF. 2004;9(2):219-20.

Silva NEK, Alvarenga AT, Ayres JRCM. Aids e gravidez: os sentidos do risco e o desafio do cuidado. Rev Saúde Pública. 2006;40(3):474-81. 
Silva VCE. O impacto da revelação do diagnóstico de câncer na percepção do paciente [dissertação]. Ribeirão Preto: Escola de Enfermagem de Ribeirão, Universidade de São Paulo; 2005.

Silveira EAA. Compreendendo os sentimentos do visitante do cliente internado com Aids [Dissertação]. Ribeirão Preto: Escola de Enfermagem de Ribeirão Preto, Universidade de São Paulo; 2004.

Silveira EAA, Carvalho AMP. Familiares de clientes acometidos pelo HIV/Aids e o atendimento prestado em uma unidade ambulatorial. Rev Lat Am Enferm. 2002;10(6):813-8.

Silveira EAA, Carvalho AMP. Vínculos afetivos na vida adulta: o visitante do paciente com aids. DST J Bras Doenças Sex Transm. 2003;15(4):33-9.

Simoni JM, Demas P, Mason HRC, Drossman JA, Davis ML. HIV disclosure among women of African descent: associations with coping, social support, and psychological adaptation. AIDS Behav. 2000;4(2):147-58.

Soares MS, Nóbrega MML, Garcia TR. Cuidados de enfermagem a uma paciente com aids à luz da variável espiritual do modelo teórico de Betty Neuman. Ciênc Cuid Saúde. 2004;3(2):187-94.

Sória DAC, Souza IEO, Moreira MC, Santoro DC, Menezes MFB. A resiliência como objeto de investigação na enfermagem e em outras áreas: uma revisão. Esc Anna Nery Rev Enferm. 2006;10(3):547-51.

Sorocaba. Secretaria Municipal de Saúde. Relatório do desenvolvimento de ações referente: fortalecimento das atividades para redução da Transmissão maternoinfantil do HIV e para eliminação da sífilis congênita no Estado da Saúde de São Paulo. Sorocaba: PMS; 2001.

Sorocaba volta ao $14^{\circ}$ lugar em casos de Aids. Cruzeiro do Sul. 1999 jul. 25; Cidades: A-3.

Souza AS, Kantorski LP, Bielemann VLM, Ornellas CP. O ser humano com Aids e a convivência em família. Texto Contexto Enferm. 2000;9(2):186-96.

Souza Júnior PRB, Szarcwald CL, Barbosa Jr A, Carvalho MF, Castilho EA. Infecção pelo HIV durante a gestação: estudo-sentinela parturiente, Brasil; 2002. Rev Saúde Pública. 2004;38(6):764-72.

Souza MJ. Auditoria do sistema de coleta de dados das gestantes HIV positivo encaminhadas pelas UBS do município de Sorocaba [monografia]. Sorocaba: Universidade Gama Filho; 2005. 
Souza NR, Vietta EP. Benefícios da interação grupal entre portadores de HIV-Aids. DST J Bras Doenças Sex Transm. 2004;16(2):10-7.

Sowell R, Moneyham L, Hennessy M, Guillory J, Demi A, Seals B. Spiritual activities as a resistance resource for women with human immunodeficiency virus. Nurs Res. 2000;49(2):73-82.

Stefani M, Araújo BF, Rocha NMP. Transmissão vertical do HIV em população de baixa renda do sul do Brasil. DST J Bras Doenças Sex Transm. 2004;16(2):33-9.

Succi RCM. Mother-to-child transmission of HIV in Brazil during the years 2000 and 2001: results of a multi-centric study. Cad Saúde Pública. 2007;23 Supl 3: S37989.

Szwarcwald CL, Barbosa Jr A, Fonseca MGP. Estimativa do número de crianças (0 14 anos) infectadas pelo HIV. Boletim Epidemiológico AIDS. 2001;15(1):49-54.

Takahashi RF, Shima H, Souza M. Mulher e Aids: perfil de uma população infectada e reflexões sobre suas implicações sociais. Rev Lat Am Enferm. 1998;6(5):59-65.

Tapajós R. A introdução das artes nos currículos médicos. Interface Comunic Saúde Educ. 2002;6(10):27-36.

Tarakeshwar N, Khan N, Sikkema KJ. A relationship-based Framework of spirituality for individuals with HIV. Aids Behav. 2006;10(1):58-70.

Teixeira JJV. O significado da intervenção médica e da fé religiosa para o paciente idoso com câncer e a percepção dos profissionais de saúde São Paulo [tese]. São Paulo: Faculdade de Saúde Pública, Universidade de São Paulo; 2003.

Thior I, Lockman S, Smeaton LM, Shapiro RL, Wester C, Heymann SJ, et al. Breastfeeding plus infant zidovudine prophylaxis for 6 months vs formula feeding plus infant zidovudine for 1 month to reduce mother-to-child HIV transmission in Botswana. JAMA. 2006;296(7):794-805.

Trinca W. Formas de investigação clínica em psicologia. São Paulo: Vetor; 1997.

Tronchin DMR, Tsunechiro MA. Cuidar e o conviver com o filho prematuro: a experiência do pai. Rev Lat Am Enferm. 2006;14(1):93-101.

Tunala LG. Fontes cotidianas de estresse entre mulheres portadoras de HIV. Rev Saúde Pública. 2002;36 Supl 4: 24-31.

Turato ER. Métodos qualitativos e quantitativos na área da saúde: definições, diferenças e seus objetos de pesquisa. Rev Saúde Pública. 2005;39(3):507-14. 
Uchôa E, Vidal JM. Antropologia médica: elementos conceituais e metodológicos para uma abordagem da saúde e da doença. Cad Saúde Pública. 1994;10(4):497-504.

Vasconcelos ALR, Hamann EM. Por que o Brasil ainda registra elevados coeficientes de transmissão vertical do HIV? Uma avaliação da qualidade da assistência prestada a gestantes/parturientes infectadas pelo HIV e seus recémnascidos. Rev Bras Saúde Matern Infant. 2005;(4):483-92.

Vaz MJR, Barros SMO. Redução da transmissão vertical do HIV: desafio para a assistência de enfermagem. Rev Lat Am Enferm. 2000;8(2):41-6.

Veras JF, Petracco MM. Adoecimento psíquico em mulheres portadoras do vírus HIV: um desafio para a clínica contemporânea. Cógito. 2004;6:137-41.

Vicentino RL. Gravidez em tempos de Aids: o desafio da maternidade, vivência das gestantes com HIV atendidas no Programa Transmissão Vertical Zero no município de Sorocaba, SP [dissertação]. São Paulo: Faculdade de Serviço Social, Pontifícia Universidade Católica de São Paulo; 2005.

Wernet M. Experiência de tornar-se mãe na unidade de cuidados intensivos neonatal [tese]. São Paulo: Escola de Enfermagem, Universidade de São Paulo; 2007.

Yunes MAM. Psicologia positiva e resiliência: o foco no indivíduo e na família. Psicol Estud. 2003;8(n. esp):75-84. 
ANEXOS 
ANEXO 1 - Autorização do Comitê de Ética em Pesquisa

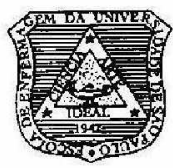

\author{
UNIVERSIDADE DE SÄO PAULO \\ ESCOLA DE ENFERMAGEM \\ Av. Dr. Enéas de Carvatho Aguiar, 419 - CEP 05403-000 \\ Z Fone: 3066-7548 - Fax.: 280-8213 \\ C.P. 41633 - CEP $05422-970=$ =-mail.: edipesq@usp.br
}

São Paulo, 10 de janeiro de 2006.

$\mathrm{Im}^{\mathrm{a}}{ }^{\mathrm{Sr}}{ }^{\mathrm{a}}$

Janie Maria de Almeida

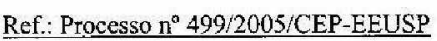

Prezada Senhora,

Em atenção à solicitação referente à análise do projeto "PROJETO TRANSMISSÃO VERTICAL ZERO: EXPECTATIVAS E AÇÕES DE PAIS SOROPOSITIVOS PARA O HIV A ESPERA PELO DIAGNÓSTICO DO FILHO", informamos que o mesmo foi considerado aprovado pelo Comitê de Ética em Pesquisa da Escola de Enfermagem da Universidade de São Paulo (CEP/EEUSP).

Analisado sob o aspecto ético-legal, atende às exigênçias da Resolução $n^{\circ} 196 / 96$ do Conselho Nacional de Saúde.

Esclarecemos que após o término da pesquisa, os resultados obtidos deverão ser encaminhados ao CEP/EEUSP, para serem anexados ao processo.

Atenciosamente,

Prof. Dr. Dulce Maria Rosa Gualda Coordenadora do Comitê de Ética em Pesquisa da Escola de Enfermagem da Universidade de São Paulo 
ANEXO 2 - Autorização do Programa Municipal DST/Aids

Sorocaba, 31 de janeiro de 2006

À Coordenadora do

Programa Municipal de DST/Aids de Sorocaba

Dr.a Maria Tereza Dib Morales

Eu, Janie Maria de Almeida enfermeira, venho por meio deste solicitar autorização para utilização das informações contidas no Banco de Dados - COASGES sobre o Projeto de Transmissão Vertical Zero do Programa Municipal de DST/AIDS de Sorocaba, com o propósito de realizar a pesquisa. "Projeto Transmissão Vertical Zero expectativas e ações de pais soropositivos para o HIV a espera pelo diagnóstico do filho", projeto para minha tese de doutorado do Programa de Pós-Graduação da Escola de Enfermagem da Universidade de São Paulo, sob orientação da Prof $\mathrm{Dr}^{2}$ Neide de Souza Praça. Este estudo tcm como objetivo: Compreender a vivência de pais de lactentes atendidos pelo Projeto Transmissão Vertical Zero, de Sorocaba, diante da indefinição do diagnóstico de soropositividade para o HIV do filho.

Por tratar-se de pesquisa a ser realizada cm dois momentos, solicito, também, autorização para contatar gestantcs inscritas no Projeto Transmissão Vertical Zero para realização de futuras entrevistas. Serão garantidos o anonimato e a voluntariedade dos sujeitos, bern como o sigilo dos dados obtidos.

Os resultados desta pesquisa serào divulgados em eventos científicos e em periódicos de circulaçâo nacional c/ou internacional c apresentados aos membros do Projeto Transmissão Vertical Zero.

Informo que este projeto de pesquisa foi submetido para análise do Comitê de Etica em Pesquisa da Escola de Enfermagem da Universidade de \$ão Paulo, e aprovada em 10 de janeiro de 2006, conforme cópia ancxa.

Agradeço a colaboraçāo para efetivaçào de meu estudo e coloco-me à disposiçào para os esclarecimentos que se fizerem necessários pelo telefone: $3227-2554$.
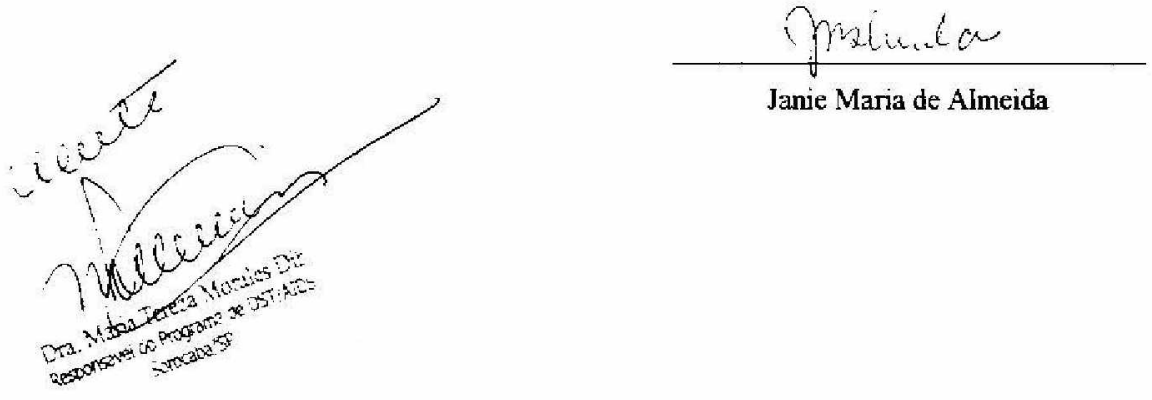
ANEXO 3 - Ficha de Gestante COAS

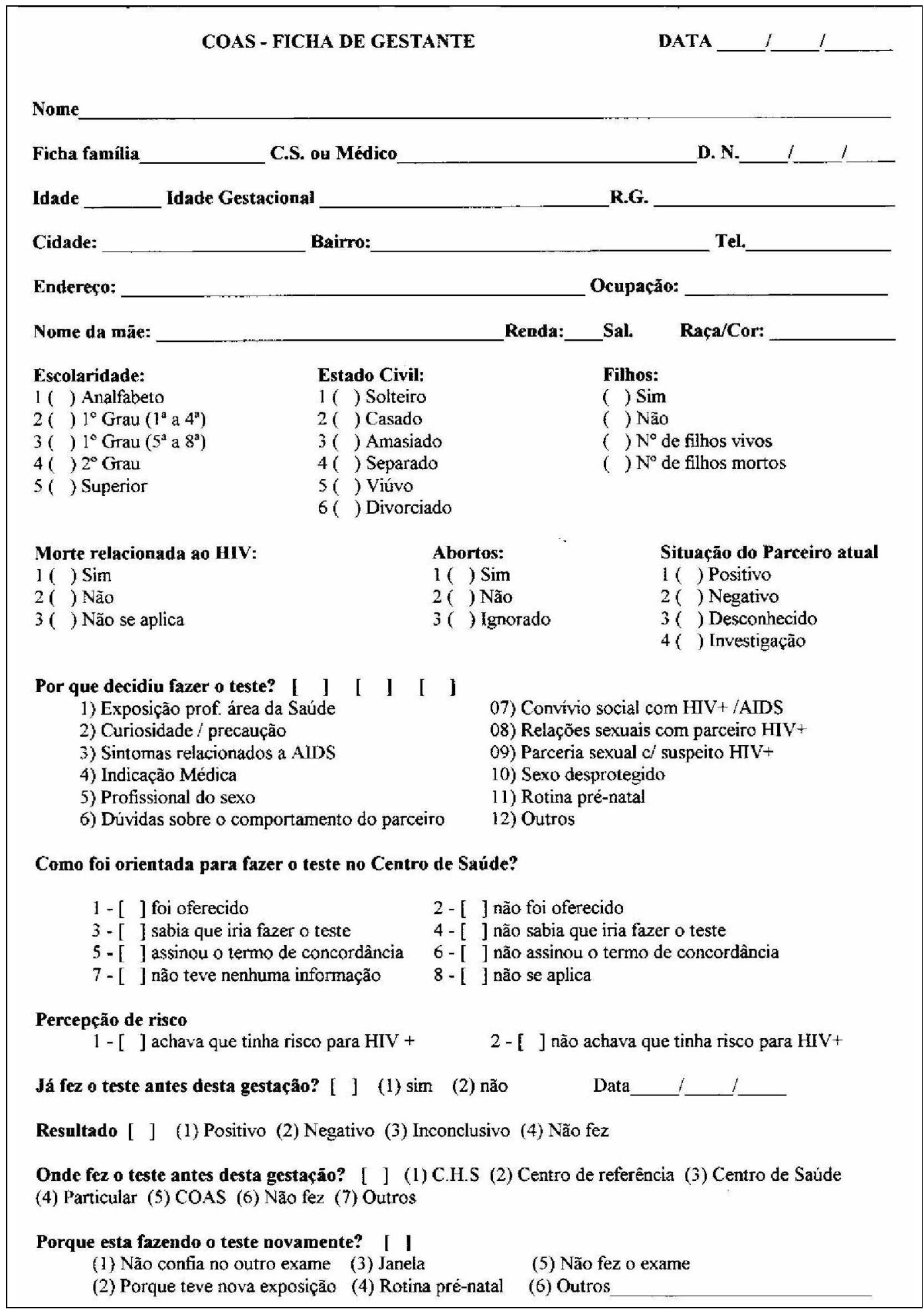

continua... 
continuação

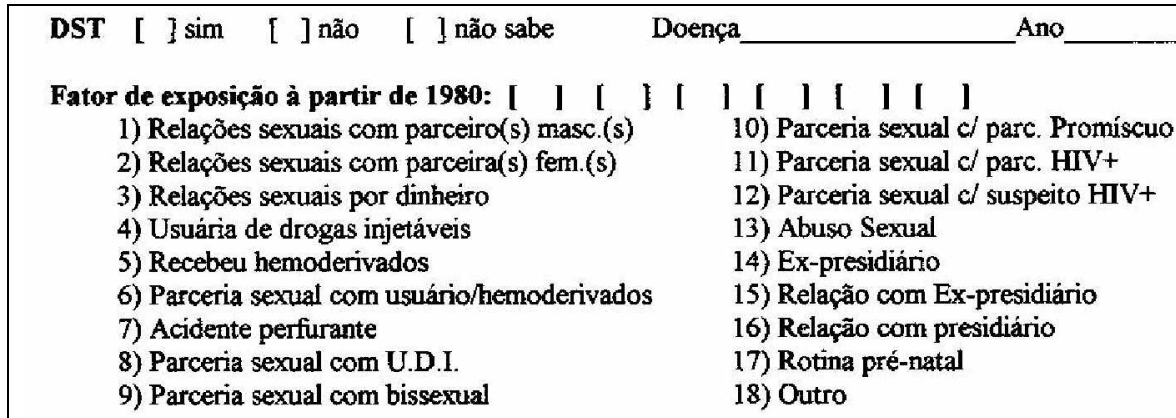

Jan. imunologica: ( ) sim ( ) não Tempo da última situação de risco

Qual tem sido sua prática serual nos últimos dez anos? [ ]

$\begin{array}{lll}\text { (1) Heterossexual (2) Homossexual (3) Bissexual } & \text { (1) }\end{array}$

No último ano quantos parceiros? [ ] [ ]

Homens (1) 0 (2) 1 (3) 2 a 4 (4) 5 a $10 \quad$ (5) +10

Mulkeres (6) 0 (7) 1 (8) 2 a 4 (9) 5 a $10 \quad(10)+10$

Uso de camisinha no último ano: [ ] $\quad$ (1) sempre $\quad$ (2) quase sempre (3) às vezes $\quad$ (4) nunca

Doaçẵo de sangue depois de 1.980? [ ] (1) sim (2) năo Quando?___ Onde

Resultado do 1"teste no C.S. ou em outro serviço? [ ] (1) Positivo (3) Indeterminado
(2) Negativo
(4) Não se aplica

\section{RESULTADOS E ENCAMINHAMENTOS:}

Responsável pela entrega:

Resultado do ELISA efetuado no COAS: ( )

(1) Positivo (2) Negativo (3) Indeterminado

Confirmatório

IMUNO [ ] (1) Positivo (2) Negativo (3) Indeterminado

BLOT [ ] (1) Positivo (2) Negativo (3) Indeterminado

Referido para [ ] (1) Clínica DST/AIDS

(2) C.H.S

(4) Não foi referido

(3) Centro de Saúde

(5) Outros

Consulta dia

Médico 


\section{APÊNDICES}




\section{APÊNDICE 1 - Termo de Consentimento Livre e Esclarecido}

\section{Prezado/a Colaborador/a}

Eu, Janie Maria de Almeida, enfermeira e aluna de Pós-Graduação da Escola de Enfermagem da USP, estou realizando a pesquisa: Projeto Transmissão Vertical Zero: expectativas e ações de pais soropositivos para o HIV à espera pelo diagnóstico do filho, que será minha tese de doutorado. Esta pesquisa tem como objetivo: Conhecer como é o dia-a-dia dos pais que esperam o diagnóstico definitivo para o HIV do filho.

O/a senhor/senhora é livre para dizer o que sente sobre o assunto da pesquisa e tem o direito de se recusar a participar e de desistir de participar a qualquer momento. A recusa de sua participação não prejudicará seu atendimento nesta clínica. Poderá fazer qualquer pergunta sobre o estudo e sobre a sua participação nele. E se tiver alguma dúvida, procurarei esclarecê-lo/a. Nossos encontros serão realizados na clínica, e serão marcados em dia de consulta, em horário e data de sua escolha, por um período aproximado de 45 minutos.

Gostaria que nosso encontro fosse gravado em fita cassete para facilitar a compreensão de sua fala, e para isso solicito sua permissão. Seu nome não aparecerá no estudo. Apenas eu terei acesso às suas informações. Os resultados obtidos nesta pesquisa serão apresentados em eventos e revistas científicas.

Poderá entrar em contato comigo e, se desejar, poderá ter acesso aos resultados obtidos nesta pesquisa, cuja previsão para término é o primeiro semestre de 2007.

Agradeço a colaboração e coloco-me à disposição para os esclarecimentos que se fizerem necessários pelo telefone: 3227-2554, caso queira esclarecer dúvidas, o telefone do Comitê de É tica e Pesquisa da Escola de Enfermagem da USP é 3066-7548.

$\mathrm{Eu}$, declaro que, após ter recebido os esclarecimentos pela pesquisadora e ter entendido o que me foi explicado, consinto participar da presente pesquisa.

Sorocaba, de de 2006. 
APÊNDICE 2 - Instrumento de Coleta - $1^{\underline{a}}$ Fase

\begin{tabular}{|c|c|c|}
\hline № da Ficha & ata_L_ I & № de Ordem \\
\hline Ocupação: & \multicolumn{2}{|c|}{ Renda Sal.: } \\
\hline $\begin{array}{l}\text { Escolaridade } \\
\begin{array}{l}\text { ( ) Analfabeto } \\
\text { ( ) } 1^{-} \text {Grau }\left(1^{\underline{a}} \text { a } 4^{\underline{a}}\right) \\
\text { ( ) } 1^{-} \text {Grau }\left(5^{\underline{a}} \text { a } 8^{\underline{a}}\right) \\
\text { ( ) } 2^{-} \text {Grau } \\
\text { ( ) Superior }\end{array}\end{array}$ & $\begin{array}{l}\text { Estado Civil } \\
\begin{array}{l}\text { ( ) Solteiro } \\
\text { ( ) Casado } \\
\text { ( ) Amasiado } \\
\text { ( ) Separado } \\
\text { ( ) Viúvo } \\
\text { ( ) Divorciado }\end{array}\end{array}$ & $\begin{array}{l}\text { Filhos } \\
\text { ( ) Sim } \\
\text { ( ) Não } \\
\text { ( ) № de Filhos vivos } \\
\text { ( ) № de Filhos Mortos }\end{array}$ \\
\hline $\begin{array}{l}\text { Situação atual do Parceiro } \\
\begin{array}{l}\text { ( ) Positivo } \\
\text { ( ) Negativo } \\
\text { ( ) Desconhecido } \\
\text { ( ) Investigação }\end{array}\end{array}$ & $\begin{array}{l}\text { Percepção de R } \\
\text { ( ) Achava que } \\
\text { ( ) Não achava }\end{array}$ & $\begin{array}{l}\text { isco } \\
\text { tinha risco para } \mathrm{HIV+} \\
\text { que tinha risco para } \mathrm{HIV+}\end{array}$ \\
\hline $\begin{array}{l}\text { Fator de exposição a partir } \\
\text { 1) Relações sexuais com parc } \\
\text { 2) Relações sexuais com paro } \\
\text { 3) Relações sexuais por dinhe } \\
\text { 4) Usuária de drogas injetáve } \\
\text { 5) Recebeu hemoderivados } \\
\text { 6) Parceira sexual com usuári } \\
\text { 7) Acidente perfurante } \\
\text { 8) Parceria Sexual com UDI } \\
\text { 9) Parceria sexual com bissex } \\
\text { 10) Parceria sexual com parce } \\
\text { 11) Parceria sexual com parc } \\
\text { 12) Parceria sexual com susp } \\
\text { 13) Abuso Sexual } \\
\text { 14) Ex-presidiário } \\
\text { 15) Relação com ex-presidiár } \\
\text { 16) Relação com presidiário } \\
\text { 17) Rotina pré-natal } \\
\text { 18) Outro }\end{array}$ & $\begin{array}{l}30()(\text { ) ( )( } \\
\text { masc.(s) } \\
\text { fem.(s) } \\
\text { drogas injetáveis } \\
\text { omíscuo } \\
\text { V+ } \\
\text { V+ }\end{array}$ & ( )( ) \\
\hline
\end{tabular}


APÊNDICE 3 - Instrumento de Coleta - 2ª Fase

\begin{tabular}{|c|c|c|}
\hline MÃE: & Data_/_/ & № de Ordem \\
\hline Ocupação: & Idade: & Religião: \\
\hline 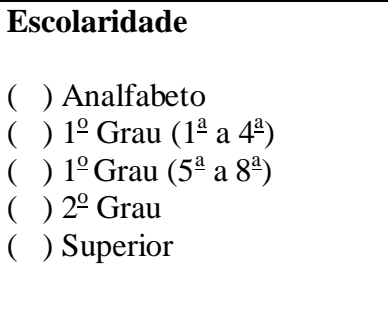 & $\begin{array}{l}\text { Estado Civil } \\
\text { ( ) Solteiro } \\
\text { ( ) Casado } \\
\text { ( ) Amasiado } \\
\text { ( ) Separado } \\
\text { ( ) Viúvo } \\
\text { ( ) Divorciado }\end{array}$ & $\begin{array}{l}\text { Filhos } \\
\text { ( ) Sim } \\
\text { ( ) Não } \\
\text { ( ) } \mathrm{N}^{\mathrm{o}} \text { de Filhos vivos } \\
\text { ( ) } \mathrm{N}^{\mathrm{o}} \text { de Filhos Mortos }\end{array}$ \\
\hline $\begin{array}{l}\text { Situação atual do Parceiro } \\
\begin{array}{l}\text { ( ) Positivo } \\
\text { ( ) Negativo } \\
\text { ( ) Desconhecido } \\
\text { ( ) Investigação }\end{array}\end{array}$ & $\begin{array}{l}\text { Percepção de Ri } \\
\text { ( ) Achava que } \\
\text { ( ) Não achava }\end{array}$ & $\begin{array}{l}\text { isco } \\
\text { tinha risco para } \mathrm{HIV+} \\
\text { que tinha risco para } \mathrm{HIV}+\end{array}$ \\
\hline $\begin{array}{l}\text { Tempo de Positividade: } \\
\text { Tempo de Adesão ao Trata }\end{array}$ & & \\
\hline Pai: & Data_/ & № de Ordem \\
\hline Ocupação: & Idade: & Religião: \\
\hline $\begin{array}{l}\text { Escolaridade } \\
\begin{array}{l}\text { ( ) Analfabeto } \\
\text { ( ) } 1^{\mathrm{o}} \text { Grau }\left(1^{\mathrm{a}} \text { a } 4^{-\mathrm{a}}\right) \\
\text { ( ) } 1^{\mathrm{o}} \text { Grau }\left(5^{\mathrm{a}} \text { a } 8^{\mathrm{a}}\right) \\
\text { ( ) } 2^{\mathrm{o}} \text { Grau } \\
\text { ( ) Superior }\end{array}\end{array}$ & $\begin{array}{l}\text { Estado Civil } \\
\text { ( ) Solteiro } \\
\text { ( ) Casado } \\
\text { ( ) Amasiado } \\
\text { ( ) Separado } \\
\text { ( ) Viúvo } \\
\text { ( ) Divorciado }\end{array}$ & $\begin{array}{l}\text { Filhos } \\
\begin{array}{l}\text { ( ) Sim } \\
\text { ( ) Não } \\
\text { ( ) № de Filhos vivos } \\
\text { ( ) } \mathrm{N}^{\mathrm{o}} \text { de Filhos Mortos }\end{array}\end{array}$ \\
\hline \multicolumn{3}{|c|}{$\begin{array}{l}\text { Tempo de Positividade: } \\
\text { Tempo de Adesão ao Tratament }\end{array}$} \\
\hline
\end{tabular}

